\title{
Hazards Assessment for the Waste Experimental Reduction Facility
}

\author{
Michael B. Calley \\ James L. Jones, Jr.
}

Published September 19, 1994

Idaho National Engineering Laboratory
EG\&G Idaho, Inc.
Idaho Falls, Idaho 83415

Prepared for the

U.S. Department of Energy

Office of Environmental Restoration and Waste Management

Under DOE Idaho Operations Office

Contract DE-AC07-76ID01570

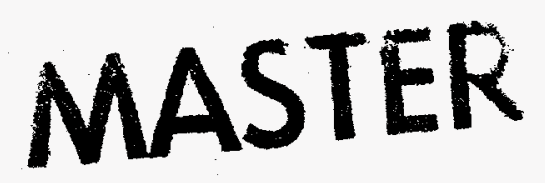




\section{DISCLAIMER}

This report was prepared as an account of work sponsored by an agency of the United States Government. Neither the United States Government nor any agency thereof, nor any of their employees, make any warranty, express or implied, or assumes any legal liability or responsibility for the accuracy, completeness, or usefulness of any information, apparatus, product, or process disclosed, or represents that its use would not infringe privately owned rights. Reference herein to any specific commercial product, process, or service by trade name, trademark, manufacturer, or otherwise does not necessarily constitute or imply its endorsement, recommendation, or favoring by the United States Government or any agency thereof. The views and opinions of authors expressed herein do not necessarily state or reflect those of the United States Government or any agency thereof. 


\section{DISCLAIMER}

Portions of this document may be illegible in electronic image products. Images are produced from the best available original document. 


\begin{abstract}
This report documents the hazards assessment for the Waste Experimental Reduction Facility (WERF) located at the Idaho National Engineering Laboratory, which is operated by EG\&G Idaho, Inc., for the U.S. Department of Energy (DOE). The hazards assessment was performed to ensure that this facility complies with DOE and company requirements pertaining to emergency planning and preparedness for operational emergencies. DOE Order 5500.3A requires that a facilityspecific hazards assessment be performed to provide the technical basis for facility emergency planning efforts. This hazards assessment was conducted in accordance with DOE Headquarters and DOE Idaho Operations Office (DOE-ID) guidance to comply with DOE Order 5500.3A. The hazards assessment identifies and analyzes hazards that are significant enough to warrant consideration in a facility's operational emergency management program. This hazards assessment describes the WERF, the area surrounding WERF, associated buildings and structures at WERF, and the processes performed at WERF. All radiological and nonradiological hazardous materials stored, used, or produced at WERF were identified and screened. Even though the screening process indicated that the hazardous materials could be screened from further analysis because the inventory of radiological and nonradiological hazardous materials were below the screening thresholds specified by DOE and DOE-ID guidance for DOE Order 5500.3A, the nonradiological hazardous materials were analyzed further because it was felt that the nonradiological hazardous material screening thresholds were too high. The nonradiological hazardous material screening thresholds were felt to be too high because there is no correlation between the screening thresholds and the protective action criteria concentration limits specified by DOE Order 5500.3A guidance. The consequence results for the analysis of the nonradiological hazardous materials are presented. Emergency considerations such as an emergency planning zone, emergency classes, protective actions, and emergency action levels based on the consequence results are also presented. This hazards assessment concludes by outlining the requirements for the maintenance and review of this hazards assessment.
\end{abstract}




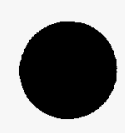

-

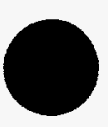




\section{CONTENTS}

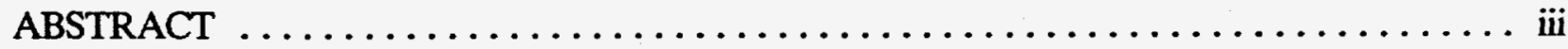

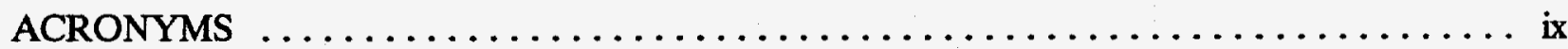

1. INTRODUCTION $\ldots \ldots \ldots \ldots \ldots \ldots \ldots \ldots \ldots \ldots \ldots \ldots \ldots \ldots \ldots \ldots \ldots \ldots \ldots \ldots$

2. FACILITY AND SITE DESCRIPTION $\ldots \ldots \ldots \ldots \ldots \ldots \ldots \ldots \ldots \ldots \ldots \ldots \ldots \ldots$

2.1 Facility Mission $\ldots \ldots \ldots \ldots \ldots \ldots \ldots \ldots \ldots \ldots \ldots \ldots \ldots \ldots \ldots \ldots \ldots \ldots \ldots \ldots, 2$

2.2 Facility Location and Demography $\ldots \ldots \ldots \ldots \ldots \ldots \ldots \ldots \ldots \ldots \ldots \ldots \ldots$

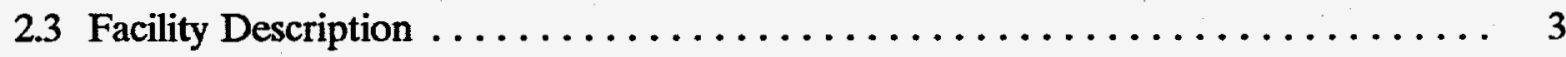

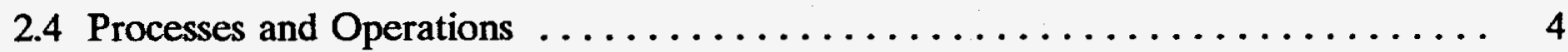

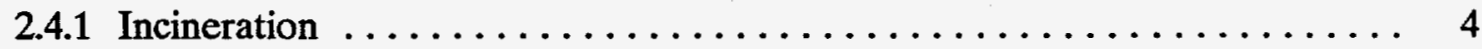

2.4 .2 Sizing $\ldots \ldots \ldots \ldots \ldots \ldots \ldots \ldots \ldots \ldots \ldots \ldots \ldots \ldots \ldots \ldots \ldots, 4$

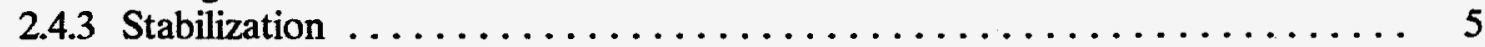

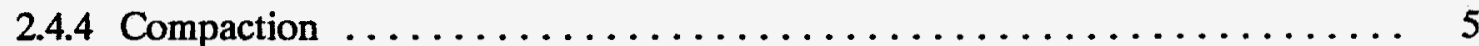

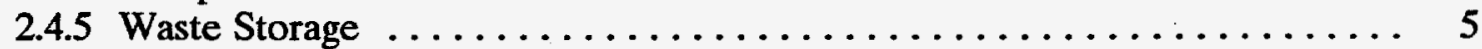

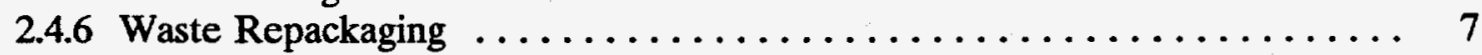

3. HAZARDS IDENTIFICATION AND SCREENING $\ldots \ldots \ldots \ldots \ldots \ldots \ldots \ldots$

3.1 Radiological Hazards $\ldots \ldots \ldots \ldots \ldots \ldots \ldots \ldots \ldots \ldots \ldots \ldots \ldots \ldots \ldots \ldots \ldots$

3.1.1 Radiological Hazards Identification $\ldots \ldots \ldots \ldots \ldots \ldots \ldots \ldots \ldots \ldots, 13$

3.1.2 Radiological Hazards Screening $\ldots \ldots \ldots \ldots \ldots \ldots \ldots \ldots \ldots \ldots \ldots \ldots \ldots$

3.2 Nonradiological Hazards $\ldots \ldots \ldots \ldots \ldots \ldots \ldots \ldots \ldots \ldots \ldots \ldots \ldots \ldots \ldots \ldots$

3.2.1 Nonradiological Hazards Identification $\ldots \ldots \ldots \ldots \ldots \ldots \ldots \ldots \ldots$

3.2.2 Nonradiological Hazards Screening $\ldots \ldots \ldots \ldots \ldots \ldots \ldots \ldots \ldots \ldots \ldots \ldots \ldots \ldots$

3.3 Commercial Energy Source Hazards $\ldots \ldots \ldots \ldots \ldots \ldots \ldots \ldots \ldots \ldots . \ldots \ldots$

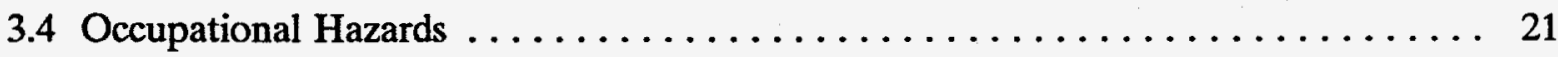

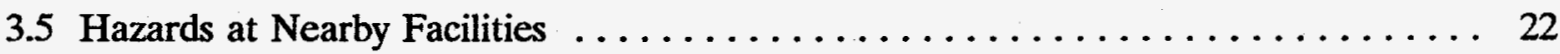

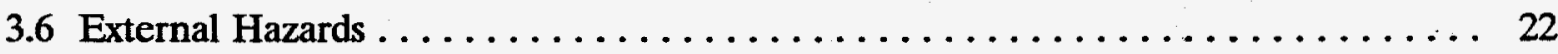

3.7 Hazardous Material Transportation Hazards $\ldots \ldots \ldots \ldots \ldots \ldots \ldots \ldots . \ldots . \ldots . \ldots$

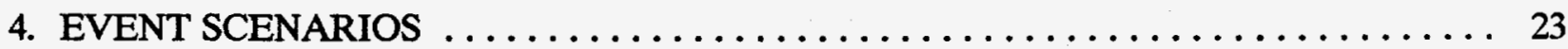

5. EVENT CONSEQUENCES $\ldots \ldots \ldots \ldots \ldots \ldots \ldots \ldots \ldots \ldots \ldots \ldots \ldots \ldots \ldots \ldots \ldots$ 


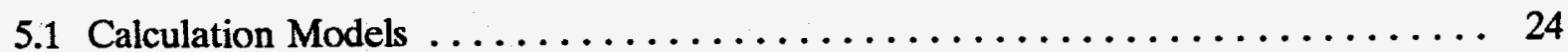

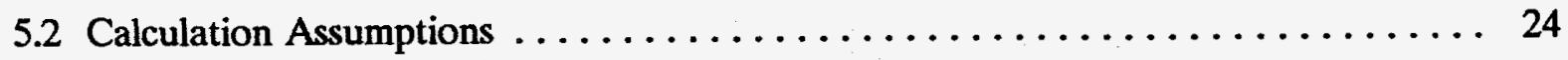

5.2 .1 Assumptions for a Fire in the wwsB .................. 24

5.2 .2 Assumptions for a Liquid Hazardous Material Spill ............... 25

5.3 Meteorological Conditions Modeled $\ldots \ldots \ldots \ldots \ldots \ldots \ldots \ldots \ldots \ldots \ldots$

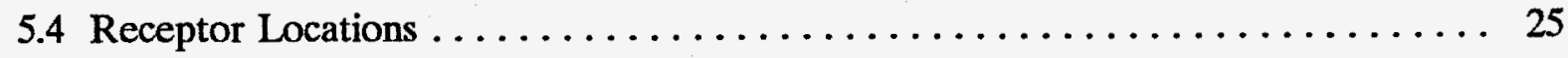

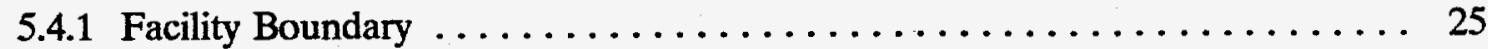

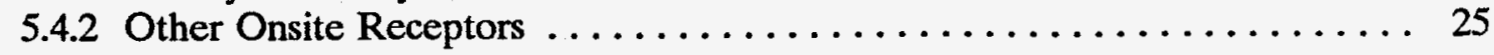

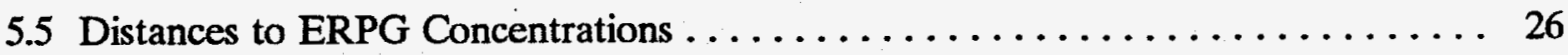

5.6 Consequence Calculation Results $\ldots \ldots \ldots \ldots \ldots \ldots \ldots \ldots \ldots \ldots \ldots \ldots \ldots$

5.6.1 Consequence Results for a Fire in the WWSB . . . . . . . . . . 27

5.6.2 Consequence Results for a Liquid Hazardous Material Spill . . . . . . . . 27

6. EMERGENCY PLANNING ZONES $\ldots \ldots \ldots \ldots \ldots \ldots \ldots \ldots \ldots \ldots \ldots \ldots \ldots \ldots \ldots$

6.1 Proposed Minimum EPZ Radius $\ldots \ldots \ldots \ldots \ldots \ldots \ldots \ldots \ldots \ldots \ldots \ldots$

6.2 Tests of Reasonableness $\ldots \ldots \ldots \ldots \ldots \ldots \ldots \ldots \ldots \ldots \ldots \ldots \ldots \ldots \ldots$

6.3 Minimum EPZ Radius $\ldots \ldots \ldots \ldots \ldots \ldots \ldots \ldots \ldots \ldots \ldots \ldots \ldots$

7. EMERGENCY CLASSES, PRGTECTIVE ACTIONS, AND EMERGENCY ACTION

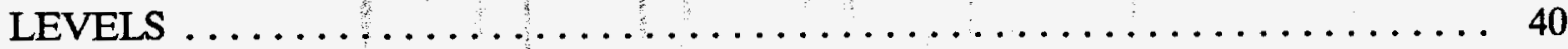

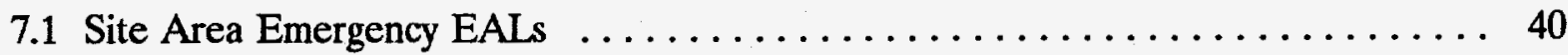

7.2 Site Area Emergency Protective Actions $\ldots \ldots \ldots \ldots \ldots \ldots \ldots \ldots \ldots \ldots$

7.2.1 Protective Actions for a Fire in the WwSB ............... 40

7.2.2 Protective Actions for a Liquid Hazardous Material Spill ........... 40

8. MAINTENANCE AND REVIEW OF THIS HAZARDS ASSESSMENT $\ldots \ldots \ldots \ldots .42$

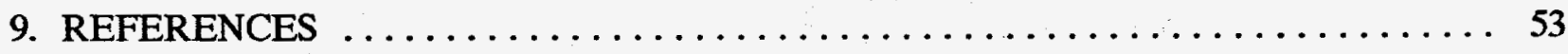

Appendix A-WERF Hazardous Commercial Material List $\ldots \ldots \ldots \ldots \ldots \ldots \ldots \ldots$ A-1

Appendix B-Facility Limits for Hazardous Materials without a TPQ or RQ $\ldots \ldots \ldots \ldots$ B-1

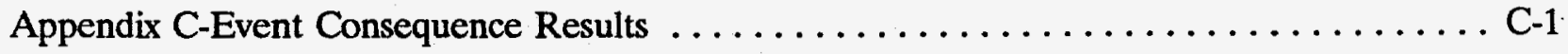




\section{FIGURES}

1. Location of WERF with respect to other WROC/WERE/PBF facilities $\ldots \ldots \ldots \ldots$

2. Location of the WROC/WERF/PBF facilities $\ldots \ldots \ldots \ldots \ldots \ldots \ldots \ldots \ldots \ldots$

3. Location of the INEL $\ldots \ldots \ldots \ldots \ldots \ldots \ldots \ldots \ldots \ldots \ldots \ldots \ldots \ldots \ldots \ldots$

4. The WERF Complex $\ldots \ldots \ldots \ldots \ldots \ldots \ldots \ldots \ldots \ldots \ldots \ldots \ldots \ldots \ldots \ldots$

5. The Minimum EPZ for WERF $\ldots \ldots \ldots \ldots \ldots \ldots \ldots \ldots \ldots \ldots \ldots \ldots \ldots$

\section{TABLES}

1. WERF radionuclide inventory and threshold quantities $\ldots \ldots \ldots \ldots \ldots \ldots \ldots \ldots$

2. Potential hazardous material inventory for the WWSB $\ldots \ldots \ldots \ldots \ldots \ldots \ldots \ldots$

3. Summary of consequence results for a fire in the WWSB $\ldots \ldots \ldots \ldots \ldots \ldots \ldots$

4. Summary of consequence results for liquid hazardous material spills $\ldots \ldots \ldots \ldots \ldots$

NOTE Reviews and approval signatures appear on DRR WR-2264.

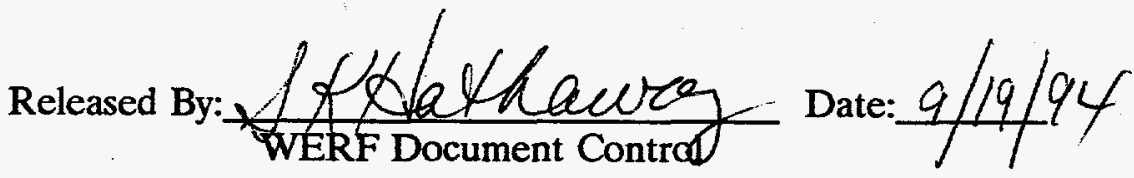


•

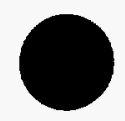




\section{ACRONYMS}

\begin{tabular}{|c|c|}
\hline ANL-W & Argonne National Laboratory-West \\
\hline CAS & Chemical Abstract Service \\
\hline CFA & Central Facilities Area \\
\hline CFR & Code of Federal Regulations \\
\hline $\mathrm{CM}$ & Configuration Management \\
\hline DOE & Department of Energy \\
\hline DOE-ID & DOE Idaho Operations Office \\
\hline DOT & Department of Transportation \\
\hline EALs & Emergency Action Levels \\
\hline EEGL & Emergency Exposure Guidance Level \\
\hline EPA & Environmental Protection Agency \\
\hline EPI & Emergency Prediction Information \\
\hline EPZ & Emergency Planning Zone \\
\hline ERPG & Emergency Response Planning Guide \\
\hline ERQ & Estimated Release Quantity \\
\hline ER\&WM & Environmental Restoration and Waste Management \\
\hline ESHE & Early Severe Health Effects \\
\hline $\mathrm{HW}$ & Hazardous Waste \\
\hline HWSF & Hazardous Waste Storage Facility \\
\hline ICPP & Idaho Chemical Processing Plant \\
\hline IDLH & Immediately Dangerous to Life and Health \\
\hline INEL & Idaho National Engineering Laboratory \\
\hline LLW & Low-Level Waste \\
\hline LOC & Level of Concern \\
\hline
\end{tabular}




\begin{tabular}{|c|c|}
\hline MLLW & Mixed Low-Level Waste \\
\hline MWSF & Mixed Waste Storage Facility \\
\hline PAG & Protective Action Guidelines \\
\hline PBF & Power Burst Facility \\
\hline PEL & Permissible Exposure Limit \\
\hline PPE & Personal Protective Equipment \\
\hline RCRA & Resource Conservation and Recovery Act \\
\hline RQ & Reportable Quantity \\
\hline RSAC & Radiological Safety Analysis Computer Program \\
\hline RWMC & Radioactive Waste Management Complex \\
\hline RWP & Radiation Work Permit \\
\hline SAR & Safety Analysis Report \\
\hline SARA & Superfund Amendment and Reauthorization Act \\
\hline STEL & Short Term Exposure Limit \\
\hline SWP & Safe Work Permit \\
\hline TAA & Temporary Accumulation Area \\
\hline TCLP & Toxicity Characteristic Leaching Procedure \\
\hline TLV & Threshold Limit Value \\
\hline TPQ & Threshold Planning Quantity \\
\hline TQ & Threshold Quantity \\
\hline TRA & Test Reactor Area \\
\hline TWA & Time Weighted Average \\
\hline USQ & Unreviewed Safety Question \\
\hline WEDF & Waste Engineering Development Facility \\
\hline WERF & Waste Experimental Reduction Facility \\
\hline
\end{tabular}

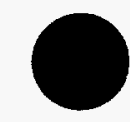


WERF Waste Storage Building

WROC

Waste Reduction Operations Complex 


\section{HAZARDS ASSESSMENT FOR THE WASTE EXPERIMENTAL REDUCTION FACILITY}

\section{INTRODUCTION}

This report documents the hazards assessment for the Waste Experimental Reduction Facility (WERF) located at the Idaho National Engineering Laboratory (INEL), which is operated by EG\&G Idaho, Inc., for the Department of Energy (DOE). The hazards assessment was conducted in accordance with guidance from DOE Headquarters ${ }^{1}$ and the DOE Idaho Operations Office (DOEID) ${ }^{2}$ to comply with DOE Order 5500.3A, "Planning and Preparedness for Operational Emergencies, ${ }^{3}$ which requires a facility-specific hazards assessment to provide the technical basis for facility emergency planning efforts. The hazards assessment identifies and analyzes the hazards that are significant enough to warrant consideration in a facility's operational emergency management program.

This report describes the WERF, the area surrounding the WERF, the buildings and structures located within the WERF boundary, and the processes involved with the operation of WERF.

This report identifies the radiological and nonradiological hazardous materials stored, used, or produced at WERF and screens them against the screening threshold criteria specified in DOE Order $5500.3 \mathrm{~A}$ guidance. The screening process indicated that the inventory of radiological and nonradiological hazardous materials were below the recommended screening thresholds. Therefore, in accordance with DOE Order 5500.3A, all the hazardous materials were screened from further analysis.

However, the nonradiological hazardous material screening thresholds were felt to be too high because there is no correlation between the screening thresholds and the protective action criteria concentration limits specified by DOE Order 5500.3A guidance. Therefore, the nonradiological hazardous materials were evaluated for several conservative types of releases. The nonradiological hazardous material evaluation and the consequence results obtained from the evaluation are presented in this hazards assessment.

Emergency considerations, such as an emergency planning zone (EPZ), emergency classes, protective actions, and emergency action levels (EALs) based on the consequence results are also presented. The consequence results indicate that concentrations at the facility boundary would exceed the protective action criteria for a Site Area Emergency [Emergency Response Planning Guide (ERPG)-2 or equivalent]. Therefore, the highest emergency class for operational emergencies at the WERF would be a Site Area Emergency.

This hazards assessment concludes with information outlining the individuals responsible for the maintenance and review of this hazards assessment. 


\section{FACILITY AND SITE DESCRIPTION}

As stated in the INEL Site Development Plan, ${ }^{4}$ the INEL encompasses $2,300 \mathrm{~km}^{2}\left(890 \mathrm{mi}^{2}\right)$ of the northwestern portion of the Eastern Snake River Plain in southeastern Idaho. The INEL is nearly $63 \mathrm{~km}(39 \mathrm{mi})$ long from north to south and about $58 \mathrm{~km}(36 \mathrm{mi})$ wide at its broadest point. The INEL includes portions of five Idaho counties (Bingham, Bonneville, Butte, Clark, and Jefferson). The INEL was established in 1949 by the U.S. Government to build, test, and operate developmental nuclear reactors and related facilities. New facilities have been built and original buildings have been modified to accommodate testing and data gathering for reactor safety experiments, fuel studies, boiling water reactors, breeder reactors, aircraft nuclear propulsion, naval reactors, waste management programs, geothermal research, and environmental research.

The INEL is a limited access area about $72 \mathrm{~km}(45 \mathrm{mi})$ west of Idaho Falls, Idaho. The INEL is divided into distinct and geographically separate functional areas for programmatic necessity and operational efficiency. One of these areas is the Waste Reduction Operations Complex/Waste Experimental Reduction Facility/Power Burst Facility (WROC/WERF/PBF) area. One of the facilities at the WROC/WERF/PBF area is the WERF. The WERF mission, location, and description are discussed in the following subsections. A majority of the information presented is from the WERF Safety Analysis Report (SAR). ${ }^{5}$

\subsection{Facility Mission}

The current mission of WERF is to support Environmental Restoration and Waste Management (ER\&WM) Department priorities within DOE and the INEL. Specifically, WERF provides volume reduction of low-level waste (LLW), treatment of hazardous waste (HW) and mixed low-level waste (MLLW), temporary storage while awaiting processing of LLW and MLLW, and repackaging of LLW, MLLW, and HW. Volume reduction of solid LLW is provided through compaction, incineration, and sizing operations. Also, WERF provides treatment of solid and liquid MLLW and HW through incineration or stabilization. HW is generally shipped off-site for commercial treatment and is only treated at WERF on a case-by-case basis.

Operation of the metal melting activity for LLW that was part of the original design and operation basis for WERF has been discontinued. Therefore, this activity is not included as part of this hazards assessment.

\subsection{Facility Location and Demography}

WERF is located in the eastern part of the WROC/WERF/PBF area at the INEL. The WROC/WERF/PBF area is a limited access area of about 4,000 acres located approximately $34 \mathrm{~km}$ $(21 \mathrm{mi})$ east of Arco and $68 \mathrm{~km}(42 \mathrm{mi})$ west of Idaho Falls. The location of WERF with respect to other WROC/WERF/PBF facilities is shown in Figure 1. The location of the WROC/WERF/PBF facilities and other facilities at the INEL are shown in Figure 2. The location of the INEL and approximate distances to cities and towns in the region are shown in Figure 3. Figures 2 and 3 also show the nearest public access points and the transportation network for the INEL and surrounding towns.

There are no permanent residents at the INEL. The communities near the INEL and their 1990 populations include Idaho Falls with 43,929; Blackfoot with 9,646; Pocatello with 46,080; Arco with 1,016; and Atomic City with 25 . Atomic City is the nearest community to WERF and is located approximately $13 \mathrm{~km}(8 \mathrm{mi})$ to the south of WERF. The population density in Butte, Bonneville, 
Bingham, Jefferson, and Clark counties are $0.5(1.3), 15.1(39.2), 6.9(17.9), 5.8(15.0)$, and 0.2 persons $/ \mathrm{km}^{2}\left(0.5\right.$ persons $\left./ \mathrm{mi}^{2}\right)$, respectively.

The work force at the INEL varies depending on the levels of construction and the research being conducted at each of the facilities. In June 1992, the INEL employed approximately 12,531 employees. Approximately 8,383 employees work at the site facilities and approximately 4,148 employees work at facilities in Idaho Falls. Of the employees at the site, approximately 36 work at WERF, 142 work at PBF, 1,299 work at Central Facilities Area (CFA), and 2,095 work at the Idaho Chemical Processing Plant (ICPP).

Co-located facilities include the Waste Engineering Development Facility (WEDF), the Mixed Waste Storage Facility (MWSF), and the PBF reactor. The WEDF is an experimental facility used for the development of treatment methods for hazardous or mixed wastes so that the waste may be appropriately disposed of following treatment. The MWSF is housed in the former SPERT IV reactor building. Activities associated with the MWSF consist of operations associated with receiving and storage of MLLW. The PBF reactor was constructed in 1970 and was initially used to perform safety studies on light-water moderated enriched-fuel systems. Subsequently, the fuel has been unloaded from the reactor and is stored in the canal adjacent to the reactor cavity. The facility is in a shutdown condition pending initiation of decommissioning and decontamination (D\&D).

\subsection{Facility Description}

For this hazards assessment, the facility description for the WERF complex will be considered to consist of the following primary structures:

- PER-609, Incinerator Building. The main WERF building is composed of a Highbay and a Lowbay. The Highbay is a two-story (above and below grade) structure with a concrete and steel frame. The basement walls are reinforced concrete and have integral reinforced concrete columns that are part of the structural trame. The above grade walls are masonry (pumice block). A braced steel frame is located just inside the exterior masonry walls. The roof is a braced steel frame with sheet metal roofing panels.

The Lowbay, which houses office areas, utilities, and restrooms, is a single story structure abutting the west wall of the Highbay. The original building has been extended six times to accommodate equipment, power supply, and offices. Building extensions are described in the WERF SAR.

- PER-635, Auxiliary Building. PER-635 is currently scheduled for removal. It has no active processes or operations. This building is a metal building located northeast of PER609. The building is divided into three separate areas and has a reinforced concrete pad to the south and to the north.

- PER-622, Compaction and Sizing Reduction Facility. PER-622 is a one-story metal building located directly east of PER-609. The building has a concrete floor painted with epoxy paint for ease of decontamination. The building contains a self-contained enclosure for performing sizing operations. The enclosure has two main sections with the north section used for opening waste boxes and preparing the waste for sizing operations and the south section used for performing size reduction of waste. The north section includes a motorized rollup door that separates the enclosure from PER-622, an airlock room for entry and exit into the enclosure, and a sorting and stripping room. 
The south section is separated from the sorting and stripping room by bifold doors. The sizing room contains stainless steel wall panels for ease of decontamination.

The south end of PER-622 is used to house the compactor operations and includes a 200ton compactor that is filtered and exhausted into the PER-622 ventilation system.

- $\quad$ PER-623, WERF Waste Storage Building (WWSB). The WWSB is a metal building with a rigid frame. A central wall divides the building into two main sections. The north section consists of three waste storage areas plus an electrical equipment room. The south section consists of three waste storage areas. The building has a concrete floor that is finished with an epoxy enamel to render it impervious to liquids.

- PER-641, WERF Operations Support Building. PER-641 is used as an office space for administrative and support personnel. The building is a one-story prefabricated metal sided building.

These buildings and their locations are shown in Figure 4. Detailed descriptions of these and other buildings at WERF are provided in the WERF SAR.

\subsection{Processes and Operations}

The following major processes and operations have been identified for WERF. The specific location, equipment, and detailed descriptions of these processes and operations are provided in the WERF SAR.

\subsubsection{Incineration}

The purpose of the WERF incinerator is to achieve effective volume reduction of low-level combustible waste prior to disposal at the Radioactive Waste Management Complex (RWMC).

The incinerator is normally operated in 24-hour-per-day campaigns of varying lengths of time depending on the type and amount of waste to be processed. Hazardous or mixed waste is incinerated intermittently on a case-by-case basis. Characteristic ${ }^{6}$ hazardous or mixed waste may be burned as part of a LLW burn, but listed ${ }^{6}$ hazardous or mixed waste is burned separately in dedicated campaigns. This allows the segregation of the ash which must be stored until a Resource Conservation and Recovery Act (RCRA) ${ }^{6}$ permitted disposal facility is available. (Samples of the bottom ash are drawn and analyzed. If the bottom ash samples exhibit characteristics of mixed waste criteria, then the ash from a LLW and MLLW burn is stabilized and, after passing Environmental Protection Agency (EPA) toxicity characteristic leaching procedure (TCLP) ${ }^{7}$ testing, is disposed of as LLW at the RWMC. If the bottom ash samples do not exhibit characteristics of mixed waste criteria, stabilization is not performed.)

\subsubsection{Sizing}

Sizing operations are conducted for the purpose of reducing the volume of large metallic LLW components prior to disposal. Sizing is performed on LLW only and includes the sizing of metallic (ferrous and nonferrous) and wood structures. For sizing operations, principal equipment utilized includes manually operated torches such as plasma-arc and oxy-acetylene torches, various mechanical cutting devices such as saws and shears, and various saws for cutting wood waste. 
Materials such as pipes, tanks and machinery to be size reduced are introduced into the sizing building and placed in the sorting area where material having thermal insulation, wiring, or coverings is stripped to the maximum extent possible. The removed material may be either packaged for disposal or sent to the compactor or incinerator for further volume reduction. The remaining material is then transferred to the sizing area and cut into smaller, manageable pieces. This processed waste is then boxed for disposal. Personnel performing waste reduction operations in the sizing area are dressed in full personal protective equipment (PPE) including anticontamination clothing, thermal suits, and breathing air hoods or respirators as necessary for the sizing process being performed.

\subsubsection{Stabilization}

Stabilization operations are conducted to stabilize incinerator flyash, bottom ash, and sizing dustcollector dust. Stabilization is accomplished using cement which renders the hazardous constituents in a nonhazardous form. Stabilization operations have expanded to include other types of waste forms, including soils and aqueous waste forms.

\subsubsection{Compaction}

Compaction of LLW provides volume reduction of compactible waste that includes noncombustible materials (e.g., light gauge metals and glass) and acid gas producing combustible materials (e.g., plastics containing polyvinyl chloride).

Compactible waste is segregated and packaged in plastic bags by the generators at the generator site. Prior to shipment to WERF, compactible waste is certified by the generator as meeting the waste acceptance criteria (WAC) for compactible LLW. The compactible waste is placed in metal containers, shipped to WERF, and stored on the asphalt pad outside WERF prior to compaction operations.

Compaction operations consists of utilizing a forklift to place an empty metal container in the compaction chamber. The metal container is then manualiy loaded by operators with compactible LLW through the upper door on the compactor. Once the metal container is full, the compactor upper door is closed and the hydraulic system is engaged to operate the compaction ram. This loading and compacting process is repeated until the container is full. Anti-spring-back retainers are installed once the container is full and a lid is placed on the container. The container is then weighed and removed from the compaction chamber. A radiation and contamination survey is performed on the container and any needed actions, such as decontaminating the outside of the container, are performed. The loaded container is marked to identify the radiation level and radionuclide content. The container is then removed from the compactor room and stored for shipment to RWMC for disposal.

\subsubsection{Waste Storage}

The processes and operations associated with LLW and MLLW storage are discussed in the following sections.

2.4.5.1 LLW Storage. Solid LLW is stored at WERF on asphalt pads surrounding the facility. Combustible and compactible waste is shipped to WERF in weatherproof cargo containers which are used to store the waste until it is ready for treatment. Metallic waste is shipped to WERF in metal or plywood containers. Some oversized contaminated metallic waste is shipped and stored at WERF prior to treatment. If it is not feasible to place the oversized waste component into a container, the 
component is wrapped to contain the contaminated portions and to exclude moisture. Pad storage is normally organized to segregate compactible, combustible, and metallic waste into individual storage areas for ease of management of the waste.

Prior to shipment of LLW to WERF, the waste generator notifies WERF of the intended shipment date and obtains shipment approval from the WERF operations manager or designated alternate. This notification allows WERF to make the necessary preparations for hoisting and rigging equipment preparation and to ensure the waste shipment is properly documented and certified for treatment.

Upon arrival at WERF and prior to unloading the waste shipment, the documentation is examined to ensure it is properly completed. The radionuclide content quantities are noted and compared with appropriate storage inventory to verify the reported quantities do not exceed the allowed inventory. If paperwork discrepancies cannot be resolved, the shipment may not be accepted and may be returned to the waste generator. The storage inventory is updated with the reported inventory from the shipping papers. The waste shipment is visually inspected to verify that the shipment is properly packaged and not damaged. A radiation and contamination survey is performed to verify that the shipment is contamination free and that the radiation levels of the containers meet the WAC.

If no discrepancies are noted, or as soon as any discrepancies are corrected, the shipment is accepted and scheduled for off-loading. Once off-loading is completed, a radiation survey and contamination survey is performed and any radiation barriers are setup as necessary. Periodic surveillances and surveys of the outside storage areas are performed to verify container integrity and ensure control of any potential contamination spread.

2.4.5.2 MLLW Storage. Storage of MLLW at WERF is performed in accordance with RCRA requirements. Designated storage locations for MLLW at WERF include the temporary accumulation area (TAA) located in the basement of the main WERF building (PER-609) and in the WWSB (PER-623). The WWSB is operating under RCRA Part A interim status.

The TAA is used as a 90-day storage facility for waste generated at WERF. The room provides a temporary storage location for MLLW or HW that is either awaiting sampling for characterization or the return of characterization data. When the characterization is completed and before the 90 days are up, the waste is either disposed of as LLW, treated, or moved to the WWSB, Hazardous Waste Storage Facility (HWSF), or the MWSF for long-term storage.

The WWSB provides long-term storage of MLLW awaiting treatment or final disposition. MLLW stored at the WWSB is packaged in approved containers and includes flammable liquid wastes, combustibie liquid wastes, liquid wastes, and solid wastes. Activities performed at WWSB include waste handling, storage, shipment, and inspection of the waste containers. Other activities at WWSB include container overpacking of leaking drums or packages, associated cleanups, and general maintenance. Initial waste receipt and inspection are performed by WROC personnel. Waste container handling between WWSB and WERF is performed by WERF operations personnel.

MLLW is transported from various generators and stored at the WWSB until treatment or a disposal option becomes available. Acceptance of waste at the WWSB is provisional upon meeting the WWSB WAC. Before waste can be shipped to the WWSB, the generator notifies WERF of the waste to be shipped for storage, fills out, and submits a Generator's Hazardous Waste Material Profile Sheet (Form EG\&G 669A) profiling the waste. Waste profile data must be based on 
verifiable process knowledge or chemical analysis of the waste. Based on the waste profile data, the generator is informed if sampling is required and if there is any special packaging or shipping requirements. All mixed waste received at the WWSB must be packaged in accordance with Department of Transportation (DOT) and RCRA regulations. The generator makes arrangements with WERF for the receipt of the waste and originates a Uniform Hazardous Waste Manifest (EPA Form 8700-22).

Upon arrival at WERF and prior to unloading the waste, the documentation is examined to ensure it is complete. The radionuclide and nonradiological hazardous material content quantities are compared with the appropriate storage inventory to verify that the reported quantities do not exceed the allowed inventory. The inventory is updated using the reported inventory amounts from the shipping papers. The WERF inventory control program is updated prior to unloading the waste.

Before acceptance at the WWSB, containers or packages are inspected by WROC personnel for leaks or any damage. A radiation and contamination survey is performed to verify that the shipment is contamination free and that the radiation levels of the containers meet the WAC. Documentation, markings, radiation levels, and labeling must be in compliance with the WAC requirements and Form EG\&G 669A. WROC Technical Programs personnel are responsible for accepting the waste into the WWSB.

Once all inspections are complete and the waste is accepted, the waste is ready to be moved to a storage location. WROC personnel specify the storage location based on drum labels or any special requirements established by the generator and a storage compatibility evaluation. WERF personnel unload and move the waste into the appropriate storage bays.

WERF operations personnel perform walk-through inspections of the facility at least weekly or before any material is moved in or out of the facility. Inspectors look for any signs of facility deterioration, damage, or malfunction as well as any signs of container breaches or leaks. The inspector visually inspects all safety and emergency equipment to ensure that there is an adequate

supply and that the equipment is within the current test date. Radiation monitoring instruments and ventilation systems are also checked to ensure proper operation.

\subsubsection{Waste Repackaging}

The purpose of waste repacking is to repackage waste in a suitable container for subsequent treatment. Some hazardous or mixed wastes are packaged in containers not suitable for incineration (i.e., metal drums) or are in a waste form or concentration not permitted for direct incineration. This waste is repackaged in cardboard boxes that are lined with a polyethylene bag. Other liner material may be substituted for polyethylene to ensure chemical resistance to the materials being repackaged.

Repackaging of non-flammable MLLW takes place in the drum feed/blending unit, the furnace room (B101 for Furnace Room No. 1 and B102 for Furnace Room No. 2), or the stabilization room (B108). Repackaging/blending of flammable liquids is only permitted in the drum feed/blending unit because the other rooms are not designed to meet the safety requirements for handling these materials.

Prior to any repackaging of MLLW, a repackaging plan is prepared that identifies the amount of waste to be placed in each box and the need for adsorbents. Personnel performing the repackaging operations are dressed and equipped with the appropriate PPE. The PPE requirements are addressed on a case-by-case basis in the Radiation Work Permit (RWP) or Safe Work Permit (SWP) for a specific job. Typically, waste material is manually extracted from 19 to $314 \mathrm{~L}$ (5 to $83 \mathrm{gal}$ ) 
containers and repackaged into an appropriate incinerable container and with absorbent material if necessary. Scoops, shovels, or hand pumps are utilized to extract the waste from the original container. Following repackaging, the new containers are marked with appropriate content information including identification number, contents, radiation levels, radionuclide content, and chemical concentration levels of the waste. Prior to removing the box from the repackaging area, a radiation and contamination survey is performed to ensure that the container is contamination free. 
Hazards Assessment for the WERF

EGG-WM-11467, September 19, 1994
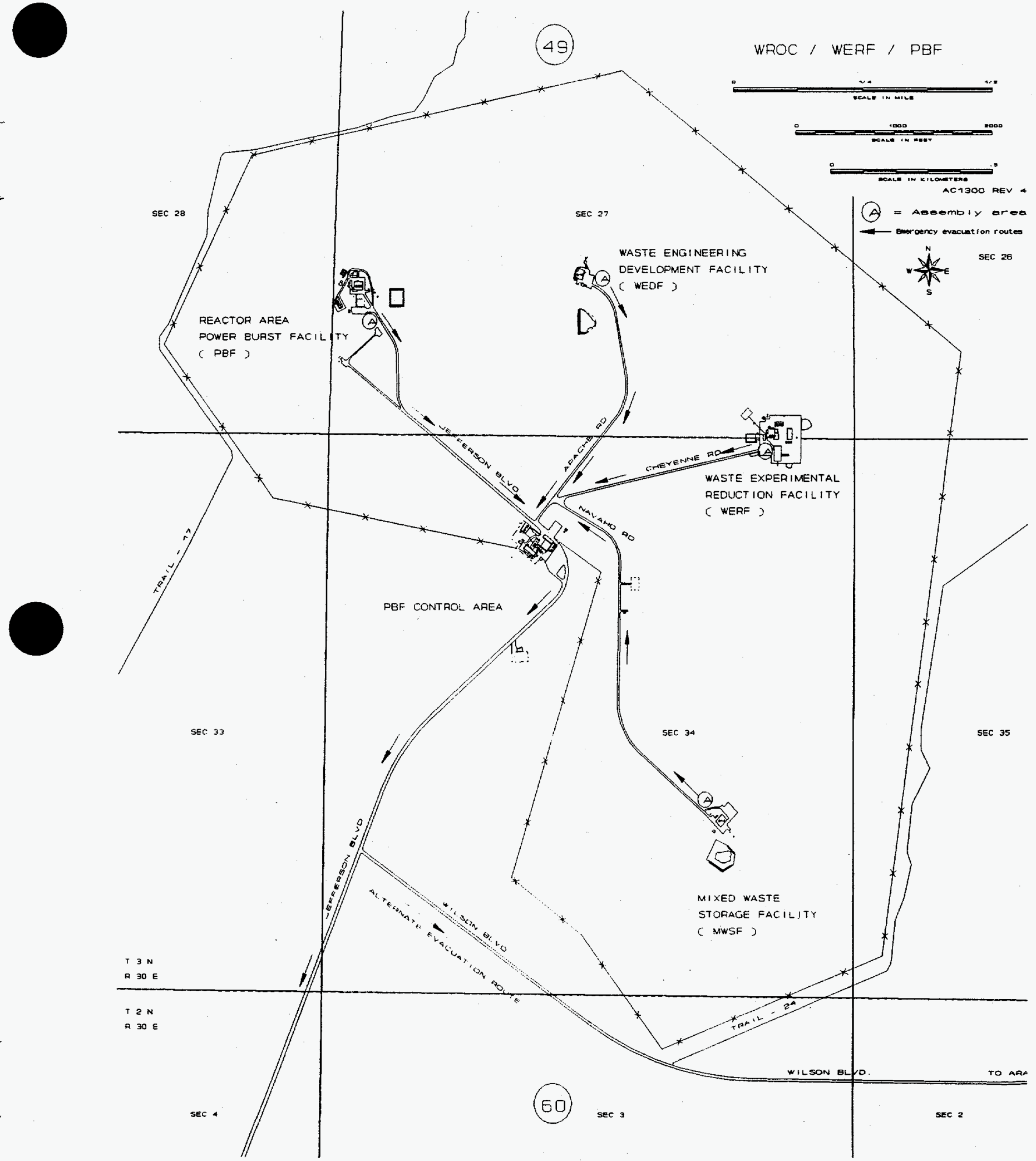

Figure 1. Location of WERF with respect to other WROC/WERE/PBF facilities. 
ARA

Auxiliary Reoctor Areo

ANL-W Argonne Notional Loboratory-West

CFA Central Facilities Areo

CTF Contained Test Facility

EBR-1 Experimental Breeder Reoctor 1

EBR-1l Experimental Breeder Reactor II

ICPP Idaho Chemical Processing Plant

IET Initiol Engine Test

NRF Naval Reactor Facility

PBF Power Burst Facility

RWMC Rodioactive Waste Monagement Complex

STF Security Troining Focility

TAN Test Areo North

TRA Test Reactor Areo

TREAT Transient Reoctor Test (Focility)

TSF Technical Support Facility

WRRTF Water Reactor Research Test Facility

ZPPR Zero Power Plutonium Reoctor

* National Historic Londmark
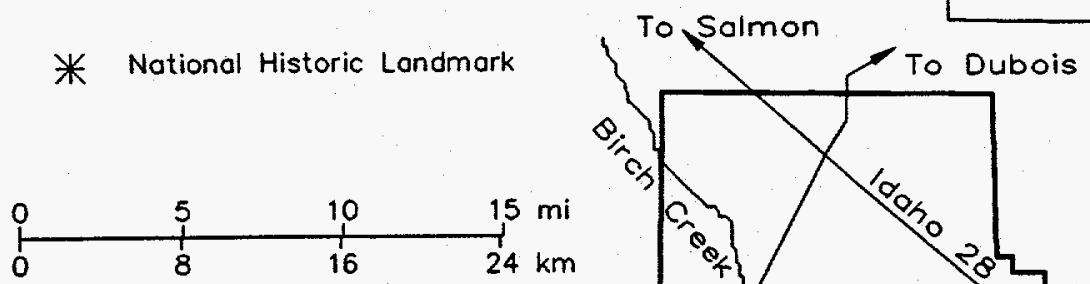

$24 \mathrm{~km}$

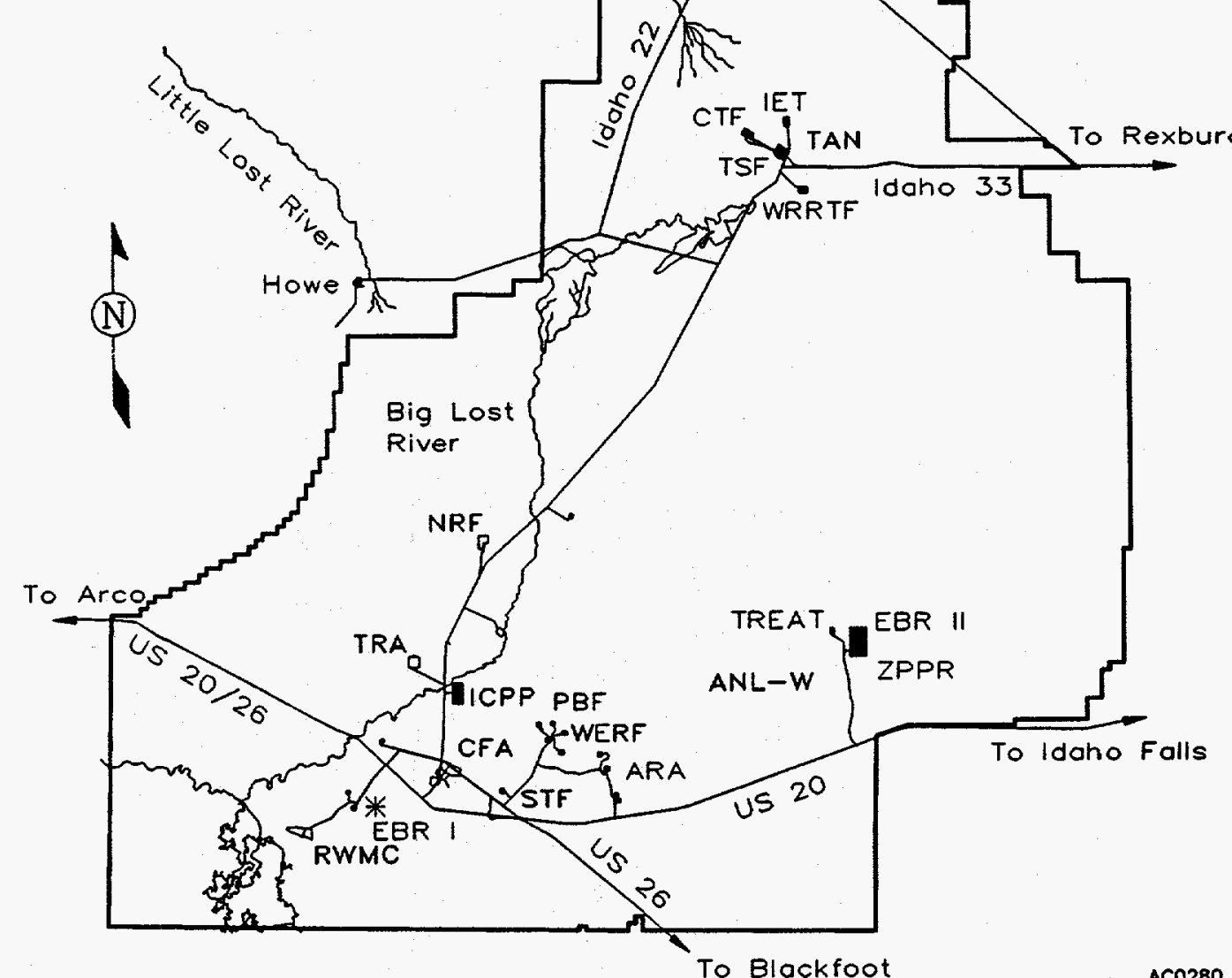

To Blackfoot

Figure 2. Location of the WROC/WERF/PBF facilities. 


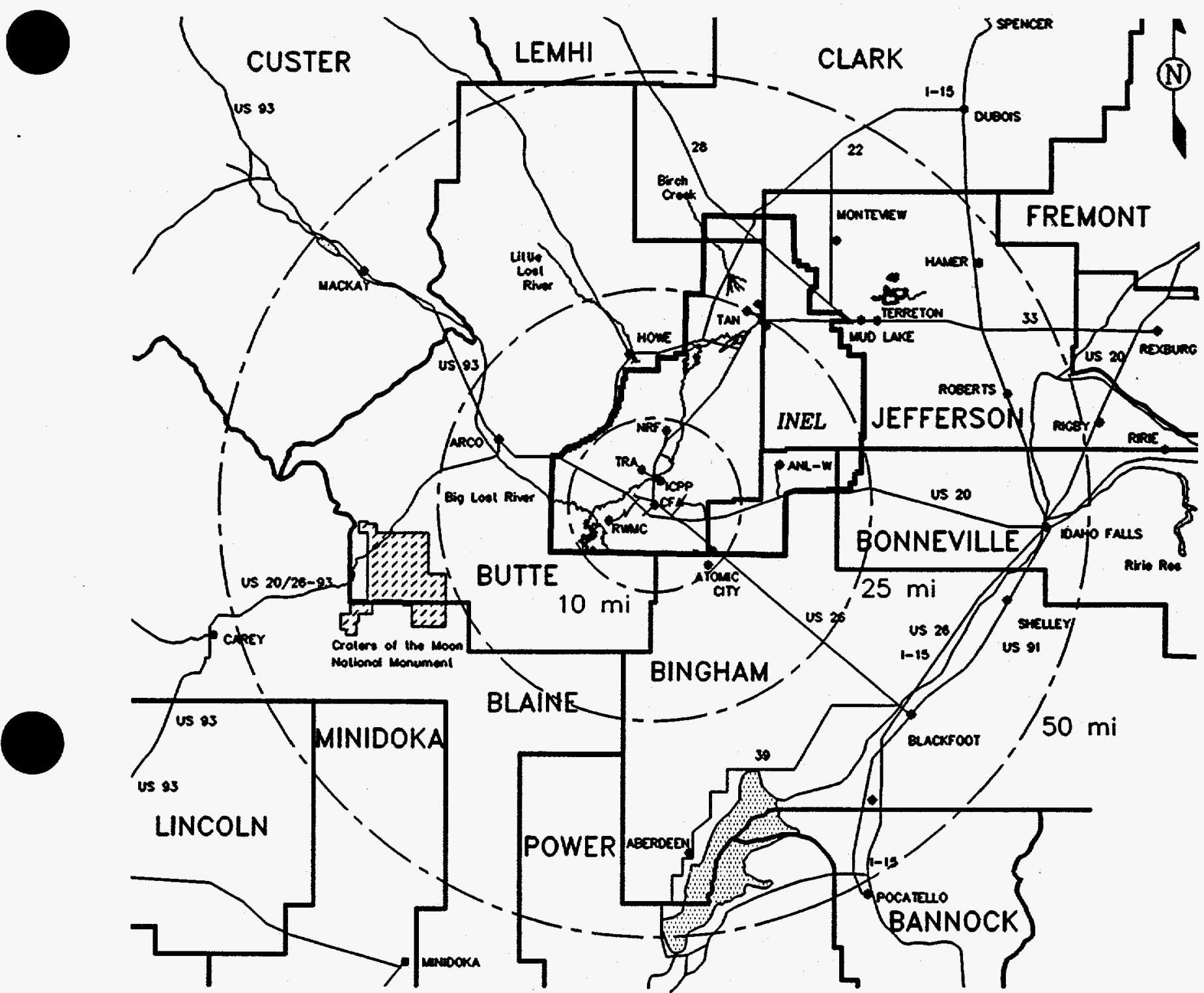

LEGEND

from Central Facilities Area

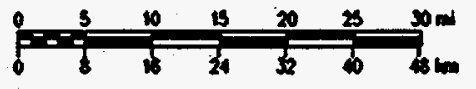

Figure 3. Location of the INEL. 


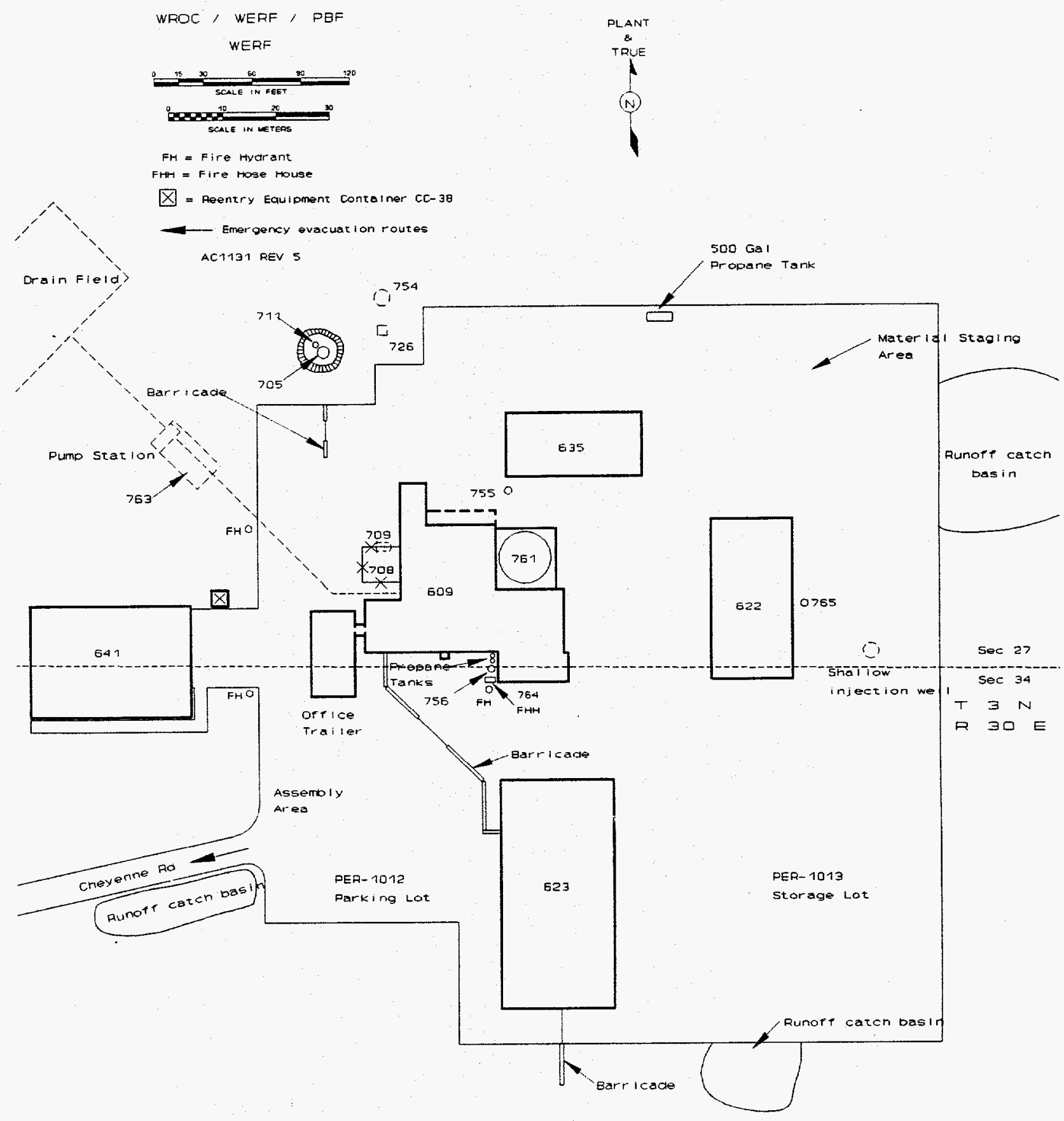

Figure 4. The WERF Complex. 


\section{HAZARDS IDENTIFICATION AND SCREENING}

The hazards such as chemical, radiological, external, and hazards at nearby facilities have been identified for WERF. These hazards are discussed in this section. For waste located at WERF, the waste may contain both radiological and nonradiological hazardous material constituents. The radiological and nonradiological constituents will be addressed separately for this hazards assessment.

\subsection{Radiological Hazards}

\subsubsection{Radiological Hazards Identification}

The radiological hazardous materials contained in the waste located at WERF were identified from the WERF SAR. Table 1 summarizes the radiological material, location, and quantity that was identified. In addition, a walkdown of WERF was conducted on January 19, 1993 to verify that the identified inventory is complete and accurate.

\subsubsection{Radiological Hazards Screening}

The identified radiological hazardous materials were screened in accordance with. DOE Order 5500.3A guidance. DOE Order 5500.3A guidance states that the quantities listed in 10 CFR Part 30.72 , Schedule $C$, may be used as screening threshold quantities (TQs) for radiological hazardous materials. Screening of the radiological hazardous materials identified at WERF is shown in Table 1. Emergency planning TQs were not exceeded for the identified radiological hazardous materials. Therefore, in accordance with DOE order 5500.3A guidance, no further characterization or analysis is required for the radiological hazardous materials identified at WERF.

\subsection{Nonradiological Hazards}

\subsubsection{Nonradiological Hazards Identification}

The nonradiological hazardous materials that may be stored at WERF have been identified from the WERF SAR. These hazardous materials may or may not be contained in the waste located at WERF. The potential hazardous material inventory is listed in Table 2. This is a potential inventory because it is not a typical inventory, but rather it is the inventory that may be stored at the WERF WWSB. The inventory in Table 2 provides the hazardous material and pertinent information such as the hazardous material's associated Chemical Abstract Service (CAS) number; physical properties; applicable threshold planning quantity (TPQ), reportable quantity (RQ), or estimated release quantity (ERQ); release fraction; and facility limit. Information that was not available or that was not relevant has been left blank in the table. The facility limit is the hazardous material quantity administratively controlled at WERF. The facility limit quantity for hazardous materials at WERF is based on the hazardous material's TPQ, RQ, or ERQ. Determination of the facility limit quantity is discussed in Section 3.2.2. Nonradiological hazardous commercial products were also identified and the inventory for these materials are listed in Appendix A. The nonradiological hazardous material inventory was verified to be complete and accurate during the walkdown of WERF that was conducted on January 19,1993 . The inventory of nonradiological hazardous commercial products listed in Appendix A was also updated with the inventory as of June 16, 1994. 
Table 1. WERF radionuclide inventory and threshold quantities.

\begin{tabular}{|c|c|c|c|c|}
\hline Material & Location & $\begin{array}{l}\text { Max. Quantity } \\
\text { (Curies) }\end{array}$ & $\begin{array}{l}\text { Threshold Quantity } \\
\text { (Curies) }\end{array}$ & Source \\
\hline \multirow{18}{*}{$\begin{array}{l}\text { Mixed radioactive waste, } \\
\text { beta-gamma }\end{array}$} & PER-609 Highbay & $9.8 \mathrm{E}-01$ & 1,000 & 1 \\
\hline & Outside Storage & $2.1 E+02$ & 1,000 & 1 \\
\hline & PER-609 Incinerator & $2.1 \mathrm{E}+01$ & 1,000 & 1 \\
\hline & PER-609 Offgas & $1.2 \mathrm{E}+01$ & 1,000 & 1 \\
\hline & Baghouse & $8.4 \mathrm{E}+00$ & & \\
\hline & HEPA & $3.8 \mathrm{E}+00$ & & \\
\hline & PER-609 Ash Handling Room & $2.4 \mathrm{E}-01$ & 1,000 & 1 \\
\hline & PER-609 Stabilization & $1.4 \mathrm{E}+00$ & 1,000 & 1 \\
\hline & PER-609 TAA & $1.1 \mathrm{E}+00$ & 1,000 & $\mathbf{1}$ \\
\hline & PER-609 Furnace Room & $4.2 \mathrm{E}-01$ & 1,000 & 1 \\
\hline & PER-609 Liquid Feed Station & $1.9 \mathrm{E}-01$ & 1,000 & 1 \\
\hline & PER-622 & $1.1 \mathrm{E}+01$ & 1,000 & 1 \\
\hline & Compactor & $3.7 \mathrm{E}+00$ & & \\
\hline & Baghouse & $7.2 \mathrm{E}+00$ & & \\
\hline & HEPA & $7.3 \mathrm{E}-02$ & & \\
\hline & WWSB All Bays & $7.5 \mathrm{E}+01$ & 1,000 & 1 \\
\hline & Bays 1, 2, 3 & $3.9 \mathrm{E}+01$ & & \\
\hline & Bays 4, 5, 6 & $3.6 \mathrm{E}+01$ & & \\
\hline
\end{tabular}

1. Screening threshold established on basis of 10 CFR 30.72 , Schedule $C$, value of 1,000 Curies for mixed radioactive waste. Mixed radioactive waste, alpha limit is 20 Curies (limit for packaged waste). The alpha quantities are less than $1 \%$ of the inventory, therefore, alpha contamination is not reported. 
Table 2. Potential hazardous material inventory for the WWSB.

\begin{tabular}{|c|c|c|c|c|c|c|c|}
\hline Material & $\begin{array}{c}\text { CAS } \\
\text { number }\end{array}$ & Properties $^{a}$ & $\begin{array}{c}\mathrm{TPQ}^{\mathrm{b}} \\
(\mathrm{kg})\end{array}$ & $\begin{array}{l}R^{c} \\
(\mathrm{~kg})\end{array}$ & $\begin{array}{c}\mathrm{ERQ}^{\mathrm{d}} \\
(\mathrm{kg})\end{array}$ & $\begin{array}{l}\text { Release } \\
\text { fraction }\end{array}$ & $\begin{array}{c}\text { Facility } \\
\text { limit }^{f} \\
(\mathrm{~kg})\end{array}$ \\
\hline Acenapthene & $83-32-9$ & SIIC & & 45.4 & & 0.01 & 4,540 \\
\hline Acetic acid & $64-19-7$ & L2SC & & 2,270 & & 0.01 & 4,540 \\
\hline Acetone & $67-64-1$ & L3PF & & 2,270 & & 0.5 & 4,540 \\
\hline Acetophenone & $98-86-2$ & L2PC & & 2,270 & & 0.01 & 4,540 \\
\hline Acrylonitrile & $107-13-1$ & L3PF & 4,540 & & & & $<4,540$ \\
\hline Antimonys & $7440-36-0$ & SOIN & & 2,270 & & 0.001 & 4,540 \\
\hline Arsenic $^{\mathrm{E}}$ & $7440-38-2$ & S1IF & & 0.454 & & 0.5 & 0.9 \\
\hline Asbestos (friable) & $1332-21-4$ & SOIN & & 0.454 & & 0.001 & 454 \\
\hline Barium & $7440-39-3$ & S3RF & & & 1.7 & 0.5 & 3.4 \\
\hline Benzene & $71-43-2$ & L3IF & & 4.54 & & 0.5 & 9.1 \\
\hline Benzoic acid & $65-85-0$ & S1PC & & 2.270 & & 0.01 & 4,540 \\
\hline Benzo[a]anthracene & $56-55-3$ & SOPN & & 4.54 & & 0.001 & 4,540 \\
\hline Benzo[a]pyrene & $50-32-8$ & SOIN & & 0.454 & & 0.001 & 454 \\
\hline Benzo[b]fluoranthene & $205-99-2$ & SOIN & & 0.454 & & 0.001 & 454 \\
\hline Benzo[g,h,i]perylene & $191-24-2$ & SOIN & & 2,270 & & 0.001 & 4,540 \\
\hline Beryllium ${ }^{g}$ & $7440-41-7$ & SIIF & & 4.54 & & 0.5 & 9.1 \\
\hline Bis(2-ethylhexyl) phthalate & $117-81-7$ & SOIN & & 45.4 & & 0.001 & 4,540 \\
\hline Bismuth & $7440-69-9$ & S2IF & & & 0.2 & 0.5 & 0.4 \\
\hline Boron & $7440-42-8$ & SIPF & & & 60.5 & 0.5 & 121 \\
\hline Butanone-2 & $78-93-3$ & L3SF & & 2,270 & & 0.5 & 4,540 \\
\hline Butoxy ethanoi-2 & $111-76-2$ & L2SF & & & 112.8 & 0.5 & 225.6 \\
\hline Butyl/benzylphthalate & $85-68-7$ & LIIC & & 45.4 & & 0.01 & 4,540 \\
\hline Cadmium $^{8}$ & $7440-43-9$ & SIIF & & 4.54 & & 0.5 & 9.1 \\
\hline Calcium & $7440-70-2$ & SIRF & & & 0.7 & 0.5 & 1.4 \\
\hline Carbon tetrachloride & $56-23-5$ & LOIN & & 4.54 & & 0.001 & 4,540 \\
\hline Chlordane & $57-74-9$ & LOIN & 454 & & & & $<454$ \\
\hline Chlorine & $7782-50-5$ & GOIN & 45.4 & & & & $<45.4$ \\
\hline Chlorobenzene & $108-90-7$ & L3IF & & 45.4 & & 0.5 & 90.7 \\
\hline Chloroform & $67-66-3$ & LOIN & 4.540 & & & & $<4,540$ \\
\hline Chromiums & $7440-47-3$ & S2IF & & 2,270 & & 0.5 & 4,540 \\
\hline Chrysene & $218-01-9$ & SOIN & & 45.4 & & 0.001 & 4,540 \\
\hline Cobalt & $7440-48-4$ & SIIF & & & 0.2 & 0.5 & 0.4 \\
\hline Copper ${ }^{g}$ & $7440-50-8$ & SOIN & & 2,270 & & 0.001 & $4,540^{\circ}$ \\
\hline
\end{tabular}


Table 2. (continued).

\begin{tabular}{|c|c|c|c|c|c|c|c|}
\hline Material & $\begin{array}{c}\text { CAS } \\
\text { number }\end{array}$ & Properties $^{\mathrm{a}}$ & $\begin{array}{c}\mathrm{TPQ}^{\mathrm{b}} \\
(\mathrm{kg})\end{array}$ & $\begin{array}{l}\mathrm{RQ}^{\mathrm{c}} \\
(\mathrm{kg})\end{array}$ & $\begin{array}{c}E R Q^{d} \\
(k g)\end{array}$ & $\begin{array}{l}\text { Release } \\
\text { fraction }\end{array}$ & $\begin{array}{c}\text { Facility } \\
\text { limit }^{\mathrm{f}} \\
(\mathrm{kg})\end{array}$ \\
\hline Cresol-p & $106-44-5$ & S2IC & & 454 & & 0.01 & 4,540 \\
\hline Cresol (mixed isomers) & $1319-77-3$ & L2IC & & 454 & & 0.01 & 4,540 \\
\hline Cresol-m & $108-39-4$ & L2IC & & 454 & & 0.01 & 4,540 \\
\hline Cresol-o ${ }^{\text {h }}$ & $95-48-7$ & L2IC & 454 & & & & $<454$ \\
\hline Cresol-o & $95-48-7$ & L2IC & 4,540 & & & & $<4,540$ \\
\hline $\begin{array}{l}\text { Cyanides (soluble saits and } \\
\text { complexes) }\end{array}$ & $57-12-5$ & SOSN & & 4.54 & & 0.001 & 4,540 \\
\hline D-2,4 & $94-75-7$ & SOSN & & 45.4 & & & \\
\hline Di-n-octyphthalate & $117-84-0$ & LOIN & & 2,270 & & 0.001 & 4,540 \\
\hline Di-n-butylphthalate & $84-74-2$ & L2IC & & 4.54 & & 0.01 & 454 \\
\hline Dichlorobenzene-1,3 & $541-73-1$ & L2IC & & 45.4 & & 0.01 & 4,540 \\
\hline Dichlorobenzene-1,2 & $95-50-1$ & L2IC & & 45.4 & & 0.01 & 4,540 \\
\hline Dichlorobenzene-1,4 & $106-46-7$ & L.2IC & & 45.4 & & 0.01 & 4,540 \\
\hline Dichlorodifluoromethane & $75-71-8$ & GOIN & & 2,270 & & 1 & 2,270 \\
\hline Dichloroethane-1,1 & $75-34-3$ & L3PF & & 454 & & 0.5 & 907.2 \\
\hline Dichloroethane-1,2 & $107-06-2$ & L.3IF & & 45.4 & & 0.5 & 90.7 \\
\hline Dichloroethene-1,1 & $75-35-4$ & L4IF & & 45.4 & & 0.5 & 90.7 \\
\hline Dichloroethene-1,2 & $156-60-5$ & L3IF & & 454 & & 0.5 & 907. \\
\hline Dichloroethylene-1,1 & $75-35-4$ & L4IF & & 45.4 & & 0.5 & 90.7 \\
\hline Diethyl phthalate & $84-66-2$ & LIIC & & 454 & & 0.01 & 4,540 \\
\hline Dinitrotoluene-2,4 & $121-14-2$ & Silc & & 4.54 & & 0.01 & 454 \\
\hline Endrin ${ }^{\mathrm{b}}$ & $72-20-8$ & SOIN & 227 & & & & $<227$ \\
\hline Endrin & $72-20-8$ & SOIN & 4,540 & & & & $<4,540$ \\
\hline Ester & & L2SC & & & 16.9 & 0.01 & 1,694 \\
\hline Ethanol amine & $141-43-5$ & L2IC & & & & & \\
\hline \multicolumn{8}{|l|}{ Ether } \\
\hline Ethyl alcohol & $64-17-5$ & L3SF & & & 6,438 & 0.5 & 4,540 \\
\hline Ethylbenzene & $100-41-4$ & L3IF & & 454 & & 0.5 & 907.2 \\
\hline Ethylene diamine & $107-15-3$ & L2SC & 4,540 & & & & $<4,540$ \\
\hline $\begin{array}{l}\text { Ethylene diamine tetraacetic } \\
\text { acid (EDTA) }\end{array}$ & $60-00-4$ & $\operatorname{SOSN}$ & & 2,270 & & 0.001 & 4,540 \\
\hline Fluoranthene & $206-44-0$ & S2IC & & 45.4 & & 0.01 & 4,540 \\
\hline Fluorene & $86-73-7$ & SOIN & & 2,270 & & 0.001 & 4,540 \\
\hline
\end{tabular}


Table 2. (continued).

\begin{tabular}{|c|c|c|c|c|c|c|c|}
\hline Material & $\begin{array}{c}\text { CAS } \\
\text { number }\end{array}$ & Properties $^{a}$ & $\begin{array}{c}\mathbf{T P Q}^{\mathbf{b}} \\
(\mathrm{kg})\end{array}$ & $\begin{array}{l}\mathrm{RQ}^{\mathrm{c}} \\
(\mathrm{kg})\end{array}$ & $\begin{array}{c}\mathrm{ERQ}^{\mathrm{d}} \\
(\mathrm{kg})\end{array}$ & $\begin{array}{l}\text { Release } \\
\text { fraction }^{e}\end{array}$ & $\begin{array}{c}\text { Facility } \\
\text { limit }^{f} \\
(\mathrm{~kg})\end{array}$ \\
\hline Formic acid & $64-18-6$ & L2SC & & 2,270 & & 0.01 & 4,540 \\
\hline Freon-113 & $76-13-1$ & L3SF & & & 25,751 & 0.5 & 4,540 \\
\hline Gold monocyanide & $506-65-0$ & SOIN & & & 4.5 & 0.001 & 4,540 \\
\hline Gold & $7440-57-5$ & SOIN & & & 4,540 & 0.001 & 4,540 \\
\hline Heptachlor & $76-44-8$ & SOIN & & 0.454 & & 0.001 & 454 \\
\hline Hexachlorobenzene & $118-74-1$ & S2IC & & 4.54 & & 0.01 & 454 \\
\hline Hexachlorobutadiene & $87-68-3$ & LIIC & & 0.454 & & 0.01 & 45.4 \\
\hline Hexachloroethane & $67-72-1$ & S3IF & & 45.4 & 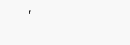 & 0.5 & 90.7 \\
\hline Hexane & $110-54-3$ & L3IF & & & 6,099 & 0.5 & 4,540 \\
\hline $\begin{array}{l}\text { Hexone (methyl isobutyl } \\
\text { ketone) }\end{array}$ & $108-10-1$ & L3PF & & 2,270 & & 0.5 & 4,540 \\
\hline Iron & $7439-89-6$ & SOIN & & & 33.9 & 0.001 & 4,540 \\
\hline Lead' & $7439-92-1$ & SOIN & & 0.454 & & 0.001 & 454 \\
\hline Lindane $^{h}$ & $58-89-9$ & SOIN & 454 & & & & $<454$ \\
\hline Lindane & $58-89-9$ & SOIN & 4,540 & & & & $<4,540$ \\
\hline Magnesium & $7439-95-4$ & S1IF & & & 33.9 & 0.5 & 67.8 \\
\hline Manganese & $7439-96-5$ & $\mathrm{~S} 2 \mathrm{RC}$ & & & 3.4 & 0.01 & 338.8 \\
\hline Mercury & $7439-97-6$ & LOIN & & 0.454 & & 0.01 & 45.4 \\
\hline Methanol (methyl alcohol) & $67-56-1$ & L3SF & & 2,270 & & 0.5 & 4,540 \\
\hline Methoxychlor & $72-43-5$ & SOIN & & 0.454 & & 0.001 & 454 \\
\hline Methyl ethyl ketone (MEK) & $78-93-3$ & L3SF & & 2,270 & & 0.5 & $4,540^{\circ}$ \\
\hline Methylene chloride & $75-09-2$ & LIIC & & 454 & & 0.01 & 4,540 \\
\hline Methylnaphthalene-2 & $91-57-6$ & L2IC & & & 8.5 & 0.01 & 847.1 \\
\hline Mineral oil & $8020-83-5$ & LIIC & & & 16.9 & 0.01 & 1,694 \\
\hline Molybdenum & $7439-98-7$ & Silc & & & 16.9 & 0.01 & 1,694 \\
\hline Naphthalene & $91-20-3$ & S2IC & & 45.4 & & 0.01 & 4,540 \\
\hline Nickel & $7440-02-0$ & S2IC & & & & & \\
\hline Nitric acid & $7697-37-2$ & LOSN & 454 & & & & $<454$ \\
\hline Nitrobenzene & $98-95-3$ & L2IC & 4,540 & & & & $<4,540$ \\
\hline Oxalic acid & $6153-56-6$ & S1PC & & & 169.4 & 0.01 & 4,540 \\
\hline $\mathrm{PCBs}^{\mathrm{i}}$ & $1336-36-3$ & LiIC & & 0.454 & & 0.01 & 45.4 \\
\hline Pentachlorophenol & $87-86-5$ & SOIN & & 4.54 & & 0.001 & 4,540 \\
\hline Perchlorates & & LIIF & & & 0.3 & 0.5 & 0.6 \\
\hline
\end{tabular}


Table 2. (continued).

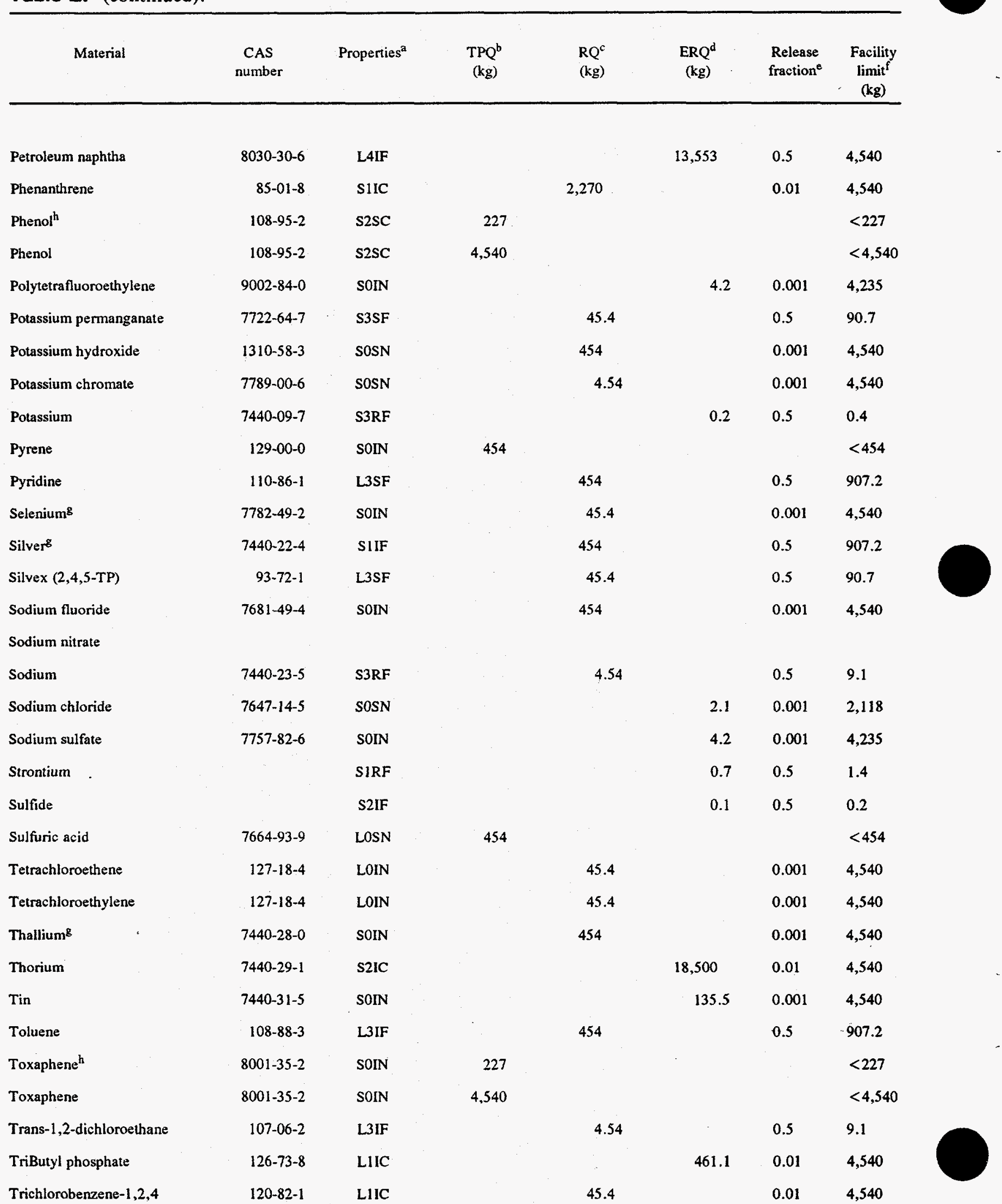


Table 2. (continued).

\begin{tabular}{|c|c|c|c|c|c|c|c|}
\hline Material & $\begin{array}{c}\text { CAS } \\
\text { number }\end{array}$ & Properties $^{a}$ & $\begin{array}{c}T{ }^{b} Q^{\circ} \\
(\mathrm{kg})\end{array}$ & $\begin{array}{l}\mathrm{RQ}^{\mathrm{c}} \\
(\mathrm{kg})\end{array}$ & $\begin{array}{c}\mathrm{ERQ}^{\mathrm{d}} \\
(\mathrm{kg})\end{array}$ & $\begin{array}{l}\text { Release } \\
\text { fraction }^{e}\end{array}$ & $\begin{array}{c}\text { Facility } \\
\text { limit }^{\mathrm{f}} \\
(\mathbf{k g})\end{array}$ \\
\hline Trichlorobenzene-1,2,3 & & LIIC & & & 15.7 & 0.01 & 1,567 \\
\hline Trichloroethane-1,1,1 & $71-55-6$ & LIIC & & 454 & & 0.01 & 4,540 \\
\hline Trichloroethene & $79-01-6$ & L2IC & & 45.4 & & 0.01 & 4,540 \\
\hline Trichloroethylene & $79-01-6$ & L2IC & & 45.4 & & 0.01 & 4,540 \\
\hline Trichlorophenol-2,4,5 & $95-95-4$ & S3IF & & 4.54 & & 0.5 & 9.1 \\
\hline Trichlorophenol-2,4,6 & $88-06-2$ & S3SF & & 4.54 & & 0.5 & 9.1 \\
\hline Trimethylbenzene-1,2.4 & $95-63-6$ & L2IC & & & 406.6 & 0.01 & 4,540 \\
\hline Vanadium & $7440-62-2$ & SIIC & & & 1.7 & 0.01 & 169.4 \\
\hline Vinyl chloride & $75-01-4$ & G4IF & & 0.454 & & 1 & 0.454 \\
\hline Xylene (mixed isomers) & $1330-20-7$ & L3IF & & 454 & & 0.5 & 907.2 \\
\hline Zinc8 & $7440-66-6$ & S2IF & & 454 & & 0.5 & 907.2 \\
\hline
\end{tabular}

a. The Properties column has a four-character identifier "ABCD." These characters are defined as follows:

$$
\begin{aligned}
& \text { A-This position denotes the physical state of the hazardous material. } \\
& \text { S-Denotes that the substance is a solid at normal temperatures } \\
& \text { L-Denotes that the substance is a liquid at normal temperatures } \\
& \text { G-Denotes that the substance is a gas at normal temperatures }
\end{aligned}
$$

B-This position denotes the "Fire Hazard" from the National Fire Protection Association (NFPA: NFPA 325M "Fire Hazard Properties of Flammable Liquids, Gases, and Volatile Solids," 1991) codes.

C-This position denotes the solubility of the substance relative to water. I-Substance is not soluble in water P-Substance is partially soluble in water $\mathrm{R}$-Substance reacts readily in water or air $S-$ Substance is soluble in water

D-This position denotes the ease with which the substance burns. F-Denotes a flammable and volatile substance C-Denotes a substance that is combustible $\mathrm{N}$-Denotes a substance that is non combustible

b. This column is the TPQ listed in 40 CFR 355, Appendix A. The List of Extremely Hazardous Substances and their Threshold Planning Quantities.

c. This column is the RQ listed in 40 CFR 302, Table 302.4, List of Hazardous Substances and Reportable Quantities.

d. This column is the estimated release quantity (ERQ). The ERQ is determined based on air concentration limits or other properties associated with the specified hazardous material. The determination of an ERQ is discussed in Appendix $B$.

e. Release fraction from U.S. Department of Energy (DOE), "Hazard Categorization and Accident Analysis Techniques for Compliance with DOE Order 5480.23, Nuclear Safety Analysis Reports," DOE-STD-1027-92, December 1992.

f. This column is the hazardous material facility limit that will be administratively maintained at WERF. The facility limit is based on the following criteria in the specified order:

1. Less than the TPQ staled in 40 CFR 355

2. Equal to the RQ from 40 CFR 302 divided by the release fraction or a maximum of $4,540.0 \mathrm{~kg}$

3. Equal to the ERQ divided by the release fraction or a maximum of $4,540.0 \mathrm{~kg}$. 
Table 2. (continued).

\begin{tabular}{|c|c|c|c|c|c|c|c|}
\hline Material & $\begin{array}{l}\text { CAS } \\
\text { number }\end{array}$ & Properties $^{\mathrm{a}}$ & $\begin{array}{c}\mathrm{TPQ}^{6} \\
(\mathrm{~kg})\end{array}$ & $\begin{array}{l}\mathrm{RQ}^{\mathrm{c}} \\
(\mathrm{kg})\end{array}$ & $\begin{array}{c}\mathrm{ERQ}^{\mathrm{d}} \\
(\mathrm{kg})\end{array}$ & $\begin{array}{l}\text { Release } \\
\text { fraction }^{\mathrm{e}}\end{array}$ & $\begin{array}{c}\text { Facility } \\
\text { limit }^{\mathrm{f}} \\
(\mathrm{kg})\end{array}$ \\
\hline
\end{tabular}

g. No reporting of this hazardous substance is required if the diameter of the pieces of the solid metal released is equal to or exceeds 100 $\mu \mathrm{m}(0.004$ in.).

h. For extremely hazardous substances (listed in 40 CFR 355) that are solids, there may be two TPQs given. In these cases, the lower quantity applies only if the solid exists in powdered form and has a particle size less than $100 \mu \mathrm{m}(0.004 \mathrm{in}$.) or is handled in solution or in molten form. Otherwise, the higher limit applies.

i. The WERF SAR states that PCBs are not allowed to be treated at WERF in concentrations greater than or equal to $5 \mathrm{ppm}$. 


\subsubsection{Nonradiological Hazards Screening}

For the hazards assessment, the hazardous materials were screened in accordance with DOE Order 5500.3A guidance. DOE Order 5500.3A guidance states that screening TQs should be used to eliminate the need to analyze insignificant hazards. The guidance documents state that the TPQ defined by the EPA Superfund Amendment and Reauthorization Act (SARA) Title III, 40 CFR Part 355, Appendix A, may be used as TQs for those chemicals listed. 40 CFR Part 355 requires that emergency planning be performed for those hazardous materials that are stored, used, or produced in an amount equal to or in excess of its TPQ. The facility limit for a hazardous material with a TPQ is a quantity less than the TPQ. Thus, the screening TQ is not exceeded for these hazardous materials.

Screening TQs were also determined for those hazardous materials that were not listed in 40 CFR 355 but were listed in the SARA Title III Consolidated List of Chemicals, 40 CFR Part 302, Table 302.4. 40 CFR Part 302 requires notification if the quantity of hazardous material released is equal to or exceeds the stated RQ. The TQs for these hazardous materials are determined by dividing the RQ listed in 40 CFR 302 by the appropriate release fraction, with the maximum TQ being limited to $4,540 \mathrm{~kg}(10,000 \mathrm{lb})$. The facility limit for these hazardous materials is equal to the determined TQ. Thus, the screening TQ is not exceeded for these hazardous materials.

For hazardous materials not listed in 40 CFR 355 or 40 CFR 302, a TQ was determined by dividing an ERQ by the appropriate release fraction, with the maximum TQ being limited to $4,540 \mathrm{~kg}$ $(10,000 \mathrm{lb})$. The ERQ for these hazardous materials were determined based on air concentration limits or other properties associated with a particular hazardous material. Determination of the ERQ for the hazardous materials indicated in Table 2 is discussed in Appendix B. The facility limit for these hazardous materials is equal to the determined TQ. Thus, the screening $T Q$ is not exceeded for these hazardous materials.

The facility limit, which is the hazardous material quantity that is administratively maintained at WERF, for each hazardous material listed in Table 2 does not exceed the screening TQ. Therefore, in accordance with DOE order 5500.3A guidance, no further characterization or analysis is required for the nonradiological hazardous materials. However, it is felt that the TQs for the hazardous materials listed in 40 CFR 355 and 40 CFR 302 may be too high because there is no correlation between the screening TQs and the protective action criteria concentration limits specified in DOE Order 5500.3A guidance. Therefore, the nonradiological hazardous materials identified at WERF that are listed in 40 CFR 355 and 40 CFR 302 will be analyzed further in Section 4 and 5.

\subsection{Commercial Energy Source Hazards}

Flammable gases and liquids at WERF are limited to fuel gases (e.g., propane cylinders), fuel oils (e.g., diesel fuel oil), and flammable constituents of other commercial products used at WERF. These items are listed in Appendix A. Appendix A indicates that over 17,000 L (4,500 gal) of No. 2-D diesel fuel oil and 2,230 L (590 gal) of propane are located at WERF. These energy sources have the potential to enhance the consequences of possible fire scenarios at WERF.

\subsection{Occupational Hazards}

Occupational hazards such as high voltage and high noise levels are identified and addressed in the WERF SAR. 


\subsection{Hazards at Nearby Facilities}

The WEDF, MWSF, PBF, and two water treatment facilities (PER-602 and PER-614) are facilities that contain hazardous materials that are located at the WROC/WERF/PBF area. WEDF is currently not being used, and no processes are taking place at this facility. Radiological and nonradiological hazardous materials are located at WEDF, but the WEDF Hazards Assessment ${ }^{8}$ indicates that there is no potential for hazardous material releases to impact WERF. The MWSF is currently being used for the storage of MLLW. The MWSF Hazards Assessment ${ }^{9}$ indicates that WERF personnel would be required to evacuate the WROC/WERF/PBF Area if an extensive fire occurred at the MWSF. PBF is a reactor facility that contains radiological and nonradiological hazards. The PBF Hazards Assessment ${ }^{10}$ indicates that WERF personnel would be required to evacuate the WROC/WERF/PBF Area if a large explosion occurred at the PBF. The two water treatment facilities contain cylinders of chlorine. The Water Treatment Facilities Hazards Assessment ${ }^{11}$ indicates that immediate protective action for WERF personnel should be to shelter within a facility if a chlorine release is detected or imminent. Evacuation should only occur if it can be done safely. WERF personnel will be evacuated in accordance with the ER\&WM Emergency Plan/RCRA Contingency Plan. ${ }^{12}$

\subsection{External Hazards}

External hazards originating outside the WROC/WERF/PBF area on the INEL site and offsite that could potentially impact the health and safety of WERF personnel were also investigated. Other facilities onsite but outside the WROC/WERF/PBF area [e.g., facilities at CFA, ICPP, Test Reactor Area (TRA), and Argonne National Laboratory-West (ANL-W)] and offsite were identified and their hazards analysis were reviewed. Based on hazard analysis results at this time, WERF would not be encompassed by an EPZ for facilities outside the WROC/WERF/PBF area.

Natural phenomena hazards, such as earthquakes, floods, winds, tornadoes, lightning strikes, volcanism, range fires, and heavy snow loads, were considered. Exposure to these events is covered in the WERF SAR.

\subsection{Hazardous Material Transportation Hazards}

Transportation of hazardous materials to and from WERF would be in quantities less than those stated in the identification and screening section. Therefore, in accordance with DOE Order 5500.3A guidance, no further analysis is required. 


\section{EVENT SCENARIOS}

Determining a bounding set of event scenarios was the first step taken in evaluating the consequences of potential releases of nonradiological hazardous materials. This bounding set of event scenarios would provide an initial assessment and a bounding set of consequences for the nonradiological hazardous materials that could be located at WERF. The bounding set of event scenarios was determined from discussions with WERF personnel, review of the hazardous materials and operations at WERF, and information contained in the WERF SAR.

In determining the bounding set of event scenarios, it was assumed that any one of the nonradiological hazardous materials identified for WERF could be involved and that the facility limit quantity for a particular hazardous material would be involved during the event. The event scenarios do not consider interactions between the hazardous materials. Interactions were not considered because the inventory presented is the facility limit inventory for each individual hazardous material and there may be numerous combinations of hazardous material inventory. However, the facility limit for each hazardous material is evaluated for the bounding set of event scenarios and therefore the results are conservative.

Operational history for WERF was also reviewed to identify any events that may be of concern for the bounding set of event scenarios. There has been contamination events at WERF, however these events were very minor and do not provide any additional insights to the bounding set of event scenarios.

A fire that occurs in the WWSB and lasts for 8 hours was the worst-case event scenario determined. This event was considered to be the worst case because it could impact the entire facility limit quantity for the hazardous materials stored in the WWSB. This event has the potential to cause a release of a hazardous material regardless of whether the hazardous material is stored in the WWSB as a solid, liquid, or gas. For details concerning this event, the WERF SAR discusses the initiating events that may lead to a fire and the extent of damage that may result. Assumptions in modeling the hazardous material dispersion are discussed in the following section.

A spill of a liquid hazardous material was also determined to be a bounding event scenario. Although hazardous materials that are liquids may be contained throughout the waste stored in the WWSB, it was assumed for this event that the entire facility limit quantity of the liquid hazardous material was spilled at once. Assumptions in modeling the hazardous material dispersion are discussed in the following section.

For hazardous materials that are gases, the only type of release modeled was a direct release of the facility limit quantity over the 8 hours of the assumed fire in the WWSB. This type of release assumes that the facility limit quantity is contained in waste throughout the facility. For example, there may be a total of 100 waste containers that each contain a small quantity of chlorinecontaminated waste, but the total quantity of chlorine is equal to the facility limit for chlorine. An instantaneous release of gas from a gas cylinder was not modeled because WERF personnel indicated that cylinders of gaseous hazardous materials are not stored at WERF. If gas cylinders are stored at WERF in the future, a hazardous material release from a gas cylinder would need to be modeled. 


\section{EVENT CONSEQUENCES}

The consequences for the event scenarios identified in Section 4 are presented in this section. The calculational models, model assumptions, and receptor locations are also presented in this section.

\subsection{Calculation Models}

Consequences for the event scenarios identified in Section 4 were estimated by determining the peak concentration levels at various receptor locations. The term peak concentration is consistent with the terminology used in the DOE Order 5500.3A guidance documents; however, the peak concentration presented in this analysis is the maximum concentration averaged over the shortest time allowed by the dispersion codes (typically, the shortest averaging time is 10 minutes). The dispersion codes used to determine the peak concentration levels at various receptor locations were either Areal Locations of Hazardous Atmospheres (ALOHA) ${ }^{13}$ Version 5.0 or Emergency Prediction Information (EPI) ${ }^{14}$ Version 5.0. ALOHA is the dispersion code in the Computer-Aided Management of Emergency Operations (CAMEO) ${ }^{15}$ code. CAMEO is the computer program used by INEL, DOE-ID, and state representatives for hazardous material emergency planning and response.

For this analysis, ALOHA was the primary code used to estimate the peak concentration levels. If a chemical was not listed in the ALOHA chemical library, the dispersion was preformed with the EPI code. If a chemical was not listed in either the ALOHA or EPI chemical library, chemical properties were researched and added to the ALOHA chemical library. The consequences of the added chemicals were then estimated with ALOHA.

\subsection{Calculation Assumptions}

The assumptions made to define the hazardous material releases that may occur for the bounding set of event scenarios are presented below. The bounding set of event scenarios includes a fire in the WWSB and a liquid hazardous material spill.

\subsubsection{Assumptions for a Fire in the WWSB}

A fire in the WWSB has the potential to affect hazardous materials at WERF whether the hazardous material is stored as a solid, liquid, or gas. For this event, a direct release was assumed for the dispersion models. The source strength for a direct release was assumed to be the TPQ or RQ (if a TPQ did not exist) for the hazardous material divided by 8 hours (the fire is assumed to burn for 8 hours).

For a fire in the WWSB, a second release type was also modeled for hazardous materials that are stored as liquids. This release type assumed that a liquid hazardous material was spilled and exposed to fire. For this release, the hazardous material puddle temperature was assumed to be equal to a ground temperature of $80^{\circ} \mathrm{C}$, which is the highest ground temperature allowed by ALOHA. If the boiling point of the hazardous material was below $80^{\circ} \mathrm{C}$, the puddle temperature was then assumed to be equal to the boiling point of the hazardous material. It was also assumed that the puddle area for the spilled liquid was equal to the maximum puddle area possible in the WWSB because a maximum puddle area provides the maximum consequences for a spilled liquid. The maximum puddle area in the WWSB is $8.6 \mathrm{~m}^{2}$. The quantity released was assumed to be equal to the TPQ, or to the RQ if no TPQ was available for the specific hazardous material. 


\subsubsection{Assumptions for a Liquid Hazardous Material Spill}

For hazardous materials that are stored as liquids at WERF, a release type of a spill (with no fire present) was assumed. The puddle temperature for a spill was assumed to be equal to a ground temperature of $20^{\circ} \mathrm{C}$. It was also assumed that the puddle area for the spilled liquid was equal to the maximum puddle area possible in the WWSB because a maximum puddle area provides the maximum consequences for a spilled liquid. The maximum puddle area in the WWSB is $8.6 \mathrm{~m}^{2}$. The quantity released was assumed to be equal to the TPQ, or to the RQ if no TPQ was available for the specific hazardous material.

\subsection{Meteorological Conditions Modeled}

Two sets of meteorological conditions were modeled for the event consequences to be consistent with the requirements in DOE Order 5500.3A guidance. The two sets of meteorological conditions included the $95 \%$ worst-case wind speed and stability for the INEL ${ }^{16}$ and a typical set of meteorological conditions at WERF. ${ }^{17}$ The $95 \%$ worst-case conditions include

- Weather Class

- Wind Speed

- Relative Humidity

- Cloud Cover

- Air Temperature

- Ground Roughness
F

$0.5 \mathrm{~m} / \mathrm{s}$ (limited to $1 \mathrm{~m} / \mathrm{s}$ by dispersion codes)

$5 \%$

Clear

$20^{\circ} \mathrm{C}$

Open country.

The typical set of meteorological conditions include

- Weather Class

- Wind Speed

- Relative Humidity

- Cloud Cover

- Air Temperature

- Ground Roughness
D

$2.5 \mathrm{~m} / \mathrm{s}$

$25 \%$

Cloudy

$20^{\circ} \mathrm{C}$

Open country.

\subsection{Receptor Locations}

Receptor locations were selected to determine the concentrations that could occur if the hazardous materials were released in the potential event scenarios. The receptor locations evaluated included the facility boundary $(100 \mathrm{~m})$, the WROC/WERF/PBF control area $(756 \mathrm{~m})$, and the nearest location where the general public has uncontrolled access $(5.2 \mathrm{~km})$. These receptor locations are discussed in the following sections.

\subsubsection{Facility Boundary}

The facility boundary was selected to be a circle 100-m around WERF. A facility boundary of $100 \mathrm{~m}$ was selected because the consequence models are not accurate for distances less than $100 \mathrm{~m}$.

\subsubsection{Other Onsite Receptors}

Other selected onsite receptor locations near WERF include the WROC/WERF/PBF control area $(756 \mathrm{~m})$ and U.S. Highway $20(5.2 \mathrm{~km})$. The WROC/WERF/PBF control area was selected because 
it is the closest facility to the WERF area. Highway 20 was selected because it is the closest location where the general public has uncontrolled access. Highway 20 is considered an uncontrolled access location because site management does not have direct control over general public access. That is, site management has no knowledge of the exact number or location of people in this area and cannot readily evacuate and establish access control of Highway 20 , which passes through the site. In addition; site management does not have the authorization to evacuate and establish access control of the highway. The following information concerns these onsite receptor locations:

- WROC/WERF/PBF Control Area-The WROC/WERF/PBF control area is approximately $756 \mathrm{~m}$ to the southwest of the WERF area. The WROC/WERF/PBF control area is occupied by approximately 90 people during normal working hours.

- U.S. Highway 20 -Highway 20 is approximately $5.2 \mathrm{~km}$ to the south of the WERF area. Highway 20 can be occupied by an unspecified number of the general public at any hour.

\subsection{Distances to ERPG Concentrations}

Several other receptor locations were also evaluated, but these receptor locations are not fixed receptor locations like those presented above. Rather, these locations are the distances to the specific ERPG for each hazardous material evaluated. ERPGs are airborne concentration levels of hazardous materials that are compared with estimated hazardous material release concentrations to determine appropriate emergency classifications and EPZs. In accordance with DOE Order 5500.3A guidance, ERPG values are defined as follows:

ERPG-1 -is the maximum airborne concentration below which it is believed that nearly all individuals could be exposed for up to one hour without experiencing other than mild transient adverse health effects or perceiving a clearly defined objectionable odor.

ERPG-2-is the maximum airborne concentration below which it is believed that nearly all individuals could be exposed for up to one hour without experiencing or developing irreversible or other serious health effects or symptoms that could impair their abilities to take protective action.

ERPG-3-is the maximum airborne concentration below which it is believed that nearly all individuals could be exposed for up to one hour without experiencing or developing lifethreatening health effects.

Emergency classifications are determined by comparing the hazardous material release concentrations to the protective action criteria. The following are definitions of company guidelines for event classifications of hazardous material releases at the INEL: ${ }^{18}$

Alert-Any release of a hazardous chemical to the atmosphere producing actual or predicted peak concentrations at or beyond any facility boundary, but not beyond any site boundary, in excess of the ERPG-1, or equivalent (PEL-STEL, TLV-STEL, 3*TLV-TWA) value for that chemical.

Site Area Emergency-Any release of a hazardous chemical to the atmosphere producing actual or predicted peak concentrations at or beyond any facility boundary, but not beyond any site boundary, in excess of the ERPG-2, or equivalent (EEGL 60 minutes, LOC, PEL-C, TLV-C, $5 *$ TLV-TWA) value for that chemical. 
General Emergency-Any release of a hazardous chemical to the atmosphere producing actual or predicted peak concentrations at or beyond any site boundary in excess of the ERPG-2, or equivalent (EEGL 60 minutes, LOC, PEL-C, TLV-C, 5*TLV-TWA) value for that chemical.

An EPZ for a facility is determined by comparing the hazardous material release concentration to the early severe health effect (ESHE) threshold. Based on DOE Order 5500.3A guidance and company guidelines for ERPG concentrations, ${ }^{18}$ the ESHE threshold for determining the EPZ corresponds to the ERPG-3, or equivalent (EEGL 30 minutes or the IDLH) value for a particular hazardous material.

The protective action criteria and ESHE threshold for each hazardous material evaluated are presented in the consequence results in Appendix C. These consequence results indicate the ERPGs or equivalent values used in determining the emergency class and distance to ESHE for the EPZ for each hazardous material evaluated.

\subsection{Consequence Calculation Results}

The consequence results for each hazardous material analyzed are presented in Appendix C. A summary of the consequence results for the modeled event scenarios are discussed below.

\subsubsection{Consequence Results for a Fire in the WWSB}

As previously stated, a fire in the WWSB has the potential to affect solid, liquid, or gaseous hazardous materials at WERF. For this event, a direct release was assumed for the dispersion models. Also, a spill of a liquid hazardous material with exposure to a fire was modeled. A summary of the consequences for a fire in the WWSB is presented in Table 3. The consequences are presented as the distances to the ERPG limits for each hazardous material that may be released due to a fire in the WWSB.

The consequence results indicate that the highest emergency class for a fire in the WWSB is a Site Area Emergency. In accordance with company guidelines, a Site Area Emergency is a hazardous material release that produces actual or predicted peak concentrations at or beyond any facility boundary, but not beyond any site boundary, in excess of the ERPG-2 or equivalent.

The consequence results also indicate that the greatest potential distance to ESHE is approximately $600 \mathrm{~m}$ for a fire in the WWSB. The distance to the ESHE is used to determine the EPZ for operational emergencies at WERF. This distance corresponds to the distance at which any release of a hazardous chemical to the atmosphere produces actual or predicted peak concentrations equal to an ERPG-3, or equivalent value.

\subsubsection{Consequence Results for a Liquid Hazardous Material Spill}

A release type of a spill was modeled for hazardous materials that are stored as liquids at WERF. A summary of the consequences for liquid hazardous material spills is presented in Table 4. The consequences presented in this table are applicable only for liquid hazardous materials that are released in a quantity equal to the TPQ, or to the RQ if no TPQ was available for the specific hazardous material.

The consequence results indicate that the highest emergency class is a Site Area Emergency for a liquid hazardous material spill. In accordance with company guidelines, a Site Area Emergency is a 
hazardous material release that produces actual or predicted peak concentrations at or beyond any facility boundary, but not beyond any site boundary, in excess of the ERPG-2 or equivalent.

The consequence results also indicate that the estimated airborne concentration would not exceed the ERPG-3 or equivalent concentration limit at a distance equal to or greater than $100 \mathrm{~m}$ for a liquid hazardous material spill. Therefore, a distance to ESHE was not determined for liquid hazardous materials spills. Concentrations within $100 \mathrm{~m}$ were not determined because of calculation limitations of the dispersion codes. 
Table 3. Summary of consequence results for a fire in the WWSB.

\begin{tabular}{|c|c|c|c|c|c|c|c|c|c|c|}
\hline \multirow[b]{2}{*}{ Material } & \multirow[b]{2}{*}{$\begin{array}{l}\text { CAS } \\
\text { number }\end{array}$} & \multirow[b]{2}{*}{ Attributes $^{\mathrm{a}}$} & \multirow[b]{2}{*}{$\begin{array}{c}T_{P Q}^{b} \\
(\mathrm{~kg})\end{array}$} & \multirow[b]{2}{*}{$\begin{array}{l}\mathrm{RQ}^{\mathbf{c}} \\
(\mathrm{kg})\end{array}$} & \multicolumn{3}{|c|}{$\begin{array}{l}\text { Direct release } \\
\text { distance to }\end{array}$} & \multicolumn{3}{|c|}{$\begin{array}{l}\text { Spill with a fire } \\
\text { distance to }\end{array}$} \\
\hline & & & & & $\begin{array}{l}\text { ERPG-I or } \\
\text { equivalent } \\
\text { (m) }\end{array}$ & $\begin{array}{l}\text { ERPG-2 or } \\
\text { equivalent } \\
\text { (m) }\end{array}$ & $\begin{array}{l}\text { ERPG-3 or } \\
\text { equivalent } \\
\text { (m) }\end{array}$ & $\begin{array}{l}\text { ERPG-1 or } \\
\text { equivalent } \\
\text { (m) }\end{array}$ & $\begin{array}{l}\text { ERPG-2 or } \\
\text { equivalent } \\
\text { (m) }\end{array}$ & $\begin{array}{c}\text { ERPG-3 or } \\
\text { equivalent } \\
\text { (m) }\end{array}$ \\
\hline Acenapthene & $83-32-9$ & 3BSIIC & & 45.4 & $\mathrm{NSC}^{\mathrm{e}}$ & NLA $^{\prime}$ & NLA & - & - & - \\
\hline Acetic acid & $64-19-7$ & IBL2SC & & 2,270 & 430 & 315 & NSC & 562 & 410 & NSC \\
\hline Acetone & $67-64-1$ & IBL3PF & & 2,270 & NSC & NSC & NSC & NSC & NSC & NSC \\
\hline Acetophenone & $98-86-2$ & 3BL2PC & & 2,270 & 1,200 & 834 & NLA & - & - & - \\
\hline Acrylonitrile & $107-13-1$ & 1 AL3PF & 4,540 & & 1,900 & 1,400 & 119 & 1,800 & 1,400 & 120 \\
\hline Arsenic ${ }^{g}$ & $7440-38-2$ & 2BSIIF & & 0.454 & 240 & 190 & NLA & - & - & - \\
\hline Asbestos (friable) & $1332-21-4$ & 2BSOIN & & 0.454 & 250 & 250 & NLA & - & - & - \\
\hline Benzene & $71-43-2$ & IBL3IF & & 4.54 & NSC & NSC & NSC & 490 & 490 & NSC \\
\hline Benzoic acid & $65-85-0$ & $3 \mathrm{BS} 1 \mathrm{PC}$ & & 2,270 & 260 & 193 & NLA & - & - & - \\
\hline Benzola]anthracene & $56-55-3$ & $3 \mathrm{BSOPN}$ & & 4.54 & 385 & 295 & NLA & - & - & - \\
\hline Benzola]pyrene & $50-32-8$ & 2BSOIN & & 0.454 & NLA & NLA & NLA & - & - & - \\
\hline Benzo[b]fluoranthene & $205-99-2$ & 3BSOIN & & 0.454 & NSC & NSC & NLA & - & - & - \\
\hline Benzolg,h,i]perylene & $191-24-2$ & $3 \mathrm{BSOIN}$ & & 2,270 & 519 & 396 & NLA & - & - & - \\
\hline Beryllium 8 & $7440-41-7$ & 2BS1IF & & 4.54 & NLA & NSC & NSC & & & \\
\hline Bis(2-ethylhexyl) phthalate & $117-81-7$ & $2 \mathrm{BSOIN}$ & & 45.4 & 260 & 160 & NLA & - & - & - \\
\hline $\begin{array}{l}\text { Butanone-2 (methyl ethyl } \\
\text { ketone) }\end{array}$ & $78-93-3$ & 2BL3SF & & 2,270 & NSC & NSC & NSC & NSC & NSC & NSC \\
\hline $\begin{array}{l}\text { Butyl/benzylphthalate } \\
(1,2 \text { benzene dicarboxylic } \\
\text { acid) }\end{array}$ & $85-68-7$ & 3BLIIC & & 45.4 & 1,300 & 711 & NLA & - & - & - \\
\hline Cadmium $\mathrm{g}$ & $7440-43-9$ & 2BS1IF & & 4.54 & 602 & 496 & NSC & - & - & - \\
\hline Carbon tetrachloride & $56-23-5$ & IBLOIN & & 4.54 & NSC & NSC & NSC & 110 & NSC & NSC \\
\hline Chlordane & $57-74-9$ & 2ALOIN & 454 & & 810 & 650 & NSC & - & - & - \\
\hline Chlorine & $7782-50-5$ & IAGOIN & 45.4 & & 756 & 400 & 120 & - & - & - \\
\hline Chlorobenzene & $108-90-7$ & 1BL.3IF & & 45.4 & NSC & NSC & NSC & 220 & 158 & NSC \\
\hline Chloroform & $67-66-3$ & 1 ALOIN & 4,540 & & 181 & NSC & NSC & 232 & NSC & NSC \\
\hline
\end{tabular}


Table 3. (continued).

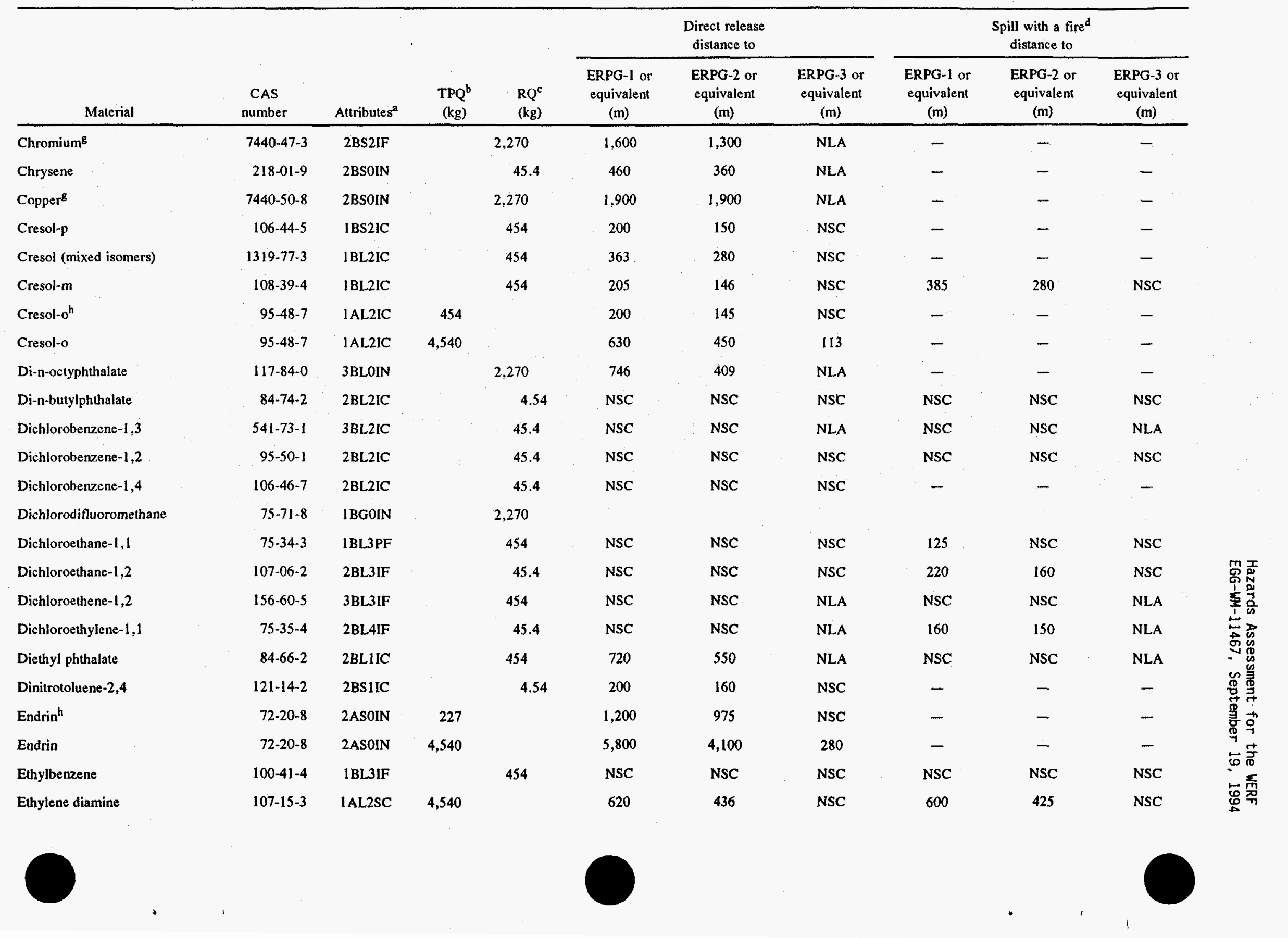


Table 3. (continued).

\begin{tabular}{|c|c|c|c|c|c|c|c|c|c|c|}
\hline \multirow[b]{2}{*}{ Material } & \multirow[b]{2}{*}{$\begin{array}{c}\text { CAS } \\
\text { number }\end{array}$} & \multirow[b]{2}{*}{ Attributes $^{a}$} & \multirow[b]{2}{*}{$\begin{array}{l}\mathrm{TPQ}^{\mathrm{b}} \\
(\mathrm{kg})\end{array}$} & \multirow[b]{2}{*}{$\begin{array}{l}\mathrm{RQ}^{\mathrm{c}} \\
(\mathrm{kg}) \\
\end{array}$} & \multicolumn{3}{|c|}{$\begin{array}{c}\text { Direct release } \\
\text { distance to }\end{array}$} & \multicolumn{3}{|c|}{$\begin{array}{l}\text { Spill with a fired } \\
\text { distance to }\end{array}$} \\
\hline & & & & & $\begin{array}{c}\text { ERPG-1 or } \\
\text { equivalent } \\
\text { (m) }\end{array}$ & $\begin{array}{l}\text { ERPG-2 or } \\
\text { equivalent } \\
(\mathrm{m})\end{array}$ & $\begin{array}{c}\text { ERPG-3 or } \\
\text { equivalent } \\
\text { (m) }\end{array}$ & $\begin{array}{c}\text { ERPG-1 or } \\
\text { equivalent } \\
\text { (m) }\end{array}$ & $\begin{array}{l}\text { ERPG-2 or } \\
\text { equivalent } \\
(m)\end{array}$ & $\begin{array}{c}\text { ERPG-3 or } \\
\text { equivalent } \\
\text { (m) }\end{array}$ \\
\hline $\begin{array}{l}\text { Ethylene diamine Tetraacetic } \\
\text { acid (EDTA) }\end{array}$ & $60-00-4$ & 3BSOSN & & 2,270 & 348 & 266 & NLA & - & - & - \\
\hline Fluoranthene & $206-44-0$ & 3BS2IC & & 45.4 & NSC & NSC & NLA & - & - & - \\
\hline Formic acid & $64-18-6$ & IBL2SC & & 2,270 & 1,100 & 603 & 530 & 1,200 & 680 & 598 \\
\hline Heptachlor & $76-44-8$ & 2BSOIN & & 0.454 & NSC & NSC & NSC & - & - & - \\
\hline Hexachlorobenzene & $118-74-1$ & $3 \mathrm{BS} 2 \mathrm{IC}$ & & 4.54 & NSC & NSC & NLA & - & - & - \\
\hline Hexachlorobutadiene & $87-68-3$ & 2BLIIC & & 0.454 & NSC & NSC & NSC & NSC & NSC & NSC \\
\hline Hexachloroethane & $67-72-1$ & 1BS3IF & & 45.4 & 168 & 130 & NSC & - & - & - \\
\hline $\begin{array}{l}\text { Hexone (methyl isobutyl } \\
\text { ketone) }\end{array}$ & $108-10-1$ & IBL3PF & & 2,270 & 175 & NSC & NSC & 107 & NSC & NSC \\
\hline Lead ${ }^{8}$ & $7439-92-1$ & 2BSOIN & & 0.454 & NSC & NSC & NSC & - & - & - \\
\hline Lindane $^{\mathrm{h}}$ & $58-89-9$ & 2ASOIN & 454 & & 820 & 650 & NSC & - & - & - \\
\hline Lindane & $58-89-9$ & $2 \mathrm{ASOIN}$ & 4,540 & & 2,100 & 1,720 & 150 & - & - & - \\
\hline Mercury & $7439-97-6$ & 2BLOIN & & 0.454 & 500 & 180 & NSC & NSC & NSC & NSC \\
\hline Methanol (methyl alcohol) & $67-56-1$ & IBL3SF & & 2,270 & 225 & NSC & NSC & 250 & NSC & NSC \\
\hline Methoxychlor & $72-43-5$ & 2BSOIN & & 0.454 & NSC & NSC & NLA & - & - & - \\
\hline Methyl ethyl ketone (MEK) & $78-93-3$ & IBL3SF & & 2,270 & NSC & NSC & NSC & 155 & NSC & NSC \\
\hline Methylene chloride & $75-09-2$ & 2BLIIC & & 454 & 125 & NSC & NSC & 175 & NSC & NSC \\
\hline Naphthalene & $91-20-3$ & IBS2IC & & 45.4 & NSC & NSC & NSC & - & - & - \\
\hline Nitric acid & $7697-37-2$ & IALOSN & 454 & & 1,100 & 300 & 200 & 2,200 & 700 & 462 \\
\hline Nitrobenzene & $98-95-3$ & 1AL2IC & 4,540 & & 1,600 & 1,100 & 119 & 1,700 & 1,200 & 127 \\
\hline Pentachlorophenol & $87-86-5$ & 2BSOIN & & 4.54 & 130 & 100 & NSC & - & - & - \\
\hline Phenanthrene & $85-01-8$ & 3BSIIC & & 2,270 & 150 & NSC & NLA & - & - & - \\
\hline Phenol ${ }^{\text {b }}$ & $108-95-2$ & 1 AS2SC & 227 & & 208 & NSC & NSC & - & - & - \\
\hline Phenol & $108-95-2$ & $1 \mathrm{AS} 2 \mathrm{SC}$ & 4,540 & & 900 & 325 & 123 & - & - & - \\
\hline
\end{tabular}


Table 3. (continued).

\begin{tabular}{|c|c|c|c|c|c|c|c|c|c|c|}
\hline \multirow[b]{2}{*}{ Material } & \multirow[b]{2}{*}{$\begin{array}{c}\text { CAS } \\
\text { number }\end{array}$} & \multirow[b]{2}{*}{ Attributes $^{\mathrm{a}}$} & \multirow[b]{2}{*}{$\begin{array}{c}\mathrm{TPQ}^{\mathrm{b}} \\
(\mathrm{kg})\end{array}$} & \multirow[b]{2}{*}{$\begin{array}{l}\mathrm{RQ}^{\mathrm{c}} \\
(\mathrm{kg})\end{array}$} & \multicolumn{3}{|c|}{$\begin{array}{l}\text { Direct release } \\
\text { distance to }\end{array}$} & \multicolumn{3}{|c|}{$\begin{array}{l}\text { Spill with a fire } \\
\text { distance to }\end{array}$} \\
\hline & & & & & $\begin{array}{c}\text { ERPG-1 or } \\
\text { equivalent } \\
\text { (m) }\end{array}$ & $\begin{array}{c}\text { ERPG-2 or } \\
\text { equivalent } \\
\text { (m) }\end{array}$ & $\begin{array}{c}\text { ERPG-3 or } \\
\text { equivalent } \\
\text { (m) }\end{array}$ & $\begin{array}{c}\text { ERPG-1 or } \\
\text { equivalent } \\
(\mathrm{m})\end{array}$ & $\begin{array}{c}\text { ERPG-2 or } \\
\text { equivalent } \\
\text { (m) }\end{array}$ & $\begin{array}{c}\text { ERPG-3 or } \\
\text { equivalent } \\
(\mathrm{m})\end{array}$ \\
\hline Potassium permanganate & $7722-64-7$ & 3BS3SF & & 45.4 & 238 & 183 & NLA & - & - & - \\
\hline Potassium hydroxide & $1310-58-3$ & $2 \mathrm{BSOSN}$ & & 454 & NLA & 756 & NLA & - & - & - \\
\hline Potassium chromate & $7789-00-6$ & $3 B S O S N$ & & 4.54 & 560 & 424 & NLA & - & - & - \\
\hline Pyrene & $129-00-0$ & 3ASOIN & 454 & & 3,200 & 2,900 & NLA & - & - & - \\
\hline Pyridine & $110-86-1$ & !BL3SF & & 454 & 260 & 185 & NSC & 600 & 440 & NSC \\
\hline Selenium ${ }^{8}$ & $7782-49-2$ & 2BSOIN & & 45.4 & 460 & 370 & NLA & - & - & - \\
\hline Silver ${ }^{8}$ & $7440-22-4$ & 2BS1IF & & 454 & 5,800 & 4,100 & NLA & - & - & - \\
\hline Silvex $(2,4,5-\mathrm{TP})$ & $93-72-1$ & 3BL3SF & & 45.4 & 526 & 400 & NLA & - & - & - \\
\hline Sodium fluoride & $7681-49-4$ & 3BSOIN & & 454 & 940 & 700 & NLA & - & - & - \\
\hline Sodium & $7440-23-5$ & 3BS3RF & & 4.54 & NSC & NSC & NLA & - & - & - \\
\hline Sulfuric acid & $7664-93-9$ & $2 \mathrm{ALOSN}$ & 454 & & 2,300 & 900 & 500 & NSC & NSC & NSC \\
\hline Tetrachloroethene & $127-18=4$ & 2BLOIN & & 45.4 & NSC & NSC & NSC & NSC & NSC & NSC \\
\hline Tetrachloroethylene & $127-18-4$ & 1BLOIN & & 45.4 & NSC & NSC & NSC & 120 & NSC & NSC \\
\hline Toluene & $108-88-3$ & IBL3IF & & 454 & NSC & NSC & NSC & 162 & 123 & NSC \\
\hline Toxaphene ${ }^{h}$ & $8001-35-2$ & 2ASOIN & 227 & & 920 & 700 & NLA & - & - & - \\
\hline Toxaphene & $8001-35-2$ & 2ASOIN & 4,540 & & 2,500 & 1,700 & NLA & - & - & - \\
\hline Trans-1,2-dichloroethane & $107-06-2$ & 2BL3IF & & 4.54 & NSC & NSC & NSC & 650 & 410 & NSC \\
\hline Trichlorobenzene-1,2,4 & $120-82-1$ & 2BLIIC & & 45.4 & NLA & 434 & NLA & - & - & - \\
\hline Trichloroethane-1,1,1 & $71-55-6$ & 2BL1IC & & 454 & NSC & NSC & NSC & NSC & NSC & NSC \\
\hline Trichloroethene & $79-01-6$ & 2BL2IC & & 45.4 & NSC & NSC & NSC & 160 & NSC & NSC \\
\hline Trichloroethylene & $79-01-6$ & 1BL2IC & & 45.4 & NSC & NSC & NSC & 150 & NSC & NSC \\
\hline Trichlorophenol-2,4,5 & $95-95-4$ & 3BS3IF & & 4.54 & NSC & NSC & NLA & - & - & - \\
\hline Trichlorophenol-2,4,6 & $88-06-2$ & 3BS3SF & & 4.54 & NSC & NSC & NLA & - & - & - \\
\hline Vinyl chloride & $75-01-4$ & 1BG4IF & & 0.454 & NSC & NSC & NLA & - & - & - \\
\hline
\end{tabular}


Table 3. (continued).

\begin{tabular}{|c|c|c|c|c|c|c|c|c|c|c|}
\hline \multirow[b]{2}{*}{ Material } & \multirow[b]{2}{*}{$\begin{array}{c}\text { CAS } \\
\text { number }\end{array}$} & \multirow[b]{2}{*}{ Attributes ${ }^{a}$} & \multirow[b]{2}{*}{$\begin{array}{c}\mathrm{TPQ}^{\mathrm{b}} \\
(\mathrm{kg})\end{array}$} & \multirow[b]{2}{*}{$\begin{array}{l}\mathrm{RQ}^{\mathrm{c}} \\
(\mathrm{kg})\end{array}$} & \multicolumn{3}{|c|}{$\begin{array}{l}\text { Direct release } \\
\text { distance to }\end{array}$} & \multicolumn{3}{|c|}{$\begin{array}{l}\text { Spill with a fire }{ }^{d} \\
\text { distance to }\end{array}$} \\
\hline & & & & & $\begin{array}{l}\text { ERPG-I or } \\
\text { equivalent } \\
\text { (m) }\end{array}$ & $\begin{array}{l}\text { ERPG-2 or } \\
\text { equivalent } \\
\text { (m) }\end{array}$ & $\begin{array}{l}\text { ERPG-3 or } \\
\text { equivalent } \\
(\mathrm{m})\end{array}$ & $\begin{array}{l}\text { ERPG-1 or } \\
\text { equivalent } \\
\text { (m) }\end{array}$ & $\begin{array}{c}\text { ERPG-2 or } \\
\text { equivalent } \\
\text { (m) }\end{array}$ & $\begin{array}{l}\text { ERPG-3 or } \\
\text { equivalent } \\
\text { (m) }\end{array}$ \\
\hline Xylene (mixed isomers) & $1330-20-7$ & IBL3IF & & 454 & NSC & NSC & NSC & 150 & NSC & NSC \\
\hline Zinc ${ }^{8}$ & $7440-66-6$ & 3BS2IF & & 454 & 576 & 407 & NLA & - & - & - \\
\hline
\end{tabular}

a. The Attributes column has a six character identifier "ABCDEF." These characters are defined as follows:

A-This position denotes if the hazardous material is

1 -in ALOHA chemical library, modeled with ALOHA

2-not in ALOHA chemical library, in EPI chemical library, modeled with EPI

3-not in ALOHA or EPI chemical library, chemical properties added to ALOHA chemical library, modeled with ALOHA

B-This position denotes if the

A-TPQ was the quantity used for the dispersion calculation

$B-R Q$ was the quantity used for the dispersion calculations

C-This position denotes the physical state of the hazardous material

$S$-Denotes that the substance is a solid at normal temperatures

L-Denotes that the substance is a liquid at normal temperature

G-Denotes that the substance is a gas at normal temperatures

D-This position denotes the fire hazard from the National Fire Protection Association (NFPA: NFPA 325M "Fire Hazard Properties of Flammable Liquids, Gases, and Volatile Solids,"

1991) codes

0-Will not burn

$1-$ Will burn at temperatures above $200^{\circ} \mathrm{F}$

2-Will burn at temperatures above $100^{\circ} \mathrm{F}$

3-Fire and explosion hazard at normal temperatures

4-Extremely dangerous fire and explosion hazard

E-This position denotes the solubility of the substance relative to water.

I-Substance is not soluble in water

P-Substance is partially soluble in water

$R$-Substance reacts readily in water or air

$\mathbf{S}$-Substance is soluble in water

F-This position denotes the ease with which the substance burns.

F-Denotes a flammable and volatile substance

C-Denotes a substance that is combustible

$\mathrm{N}$-Denotes a substance that is non combustible 
Table 3. (continued).

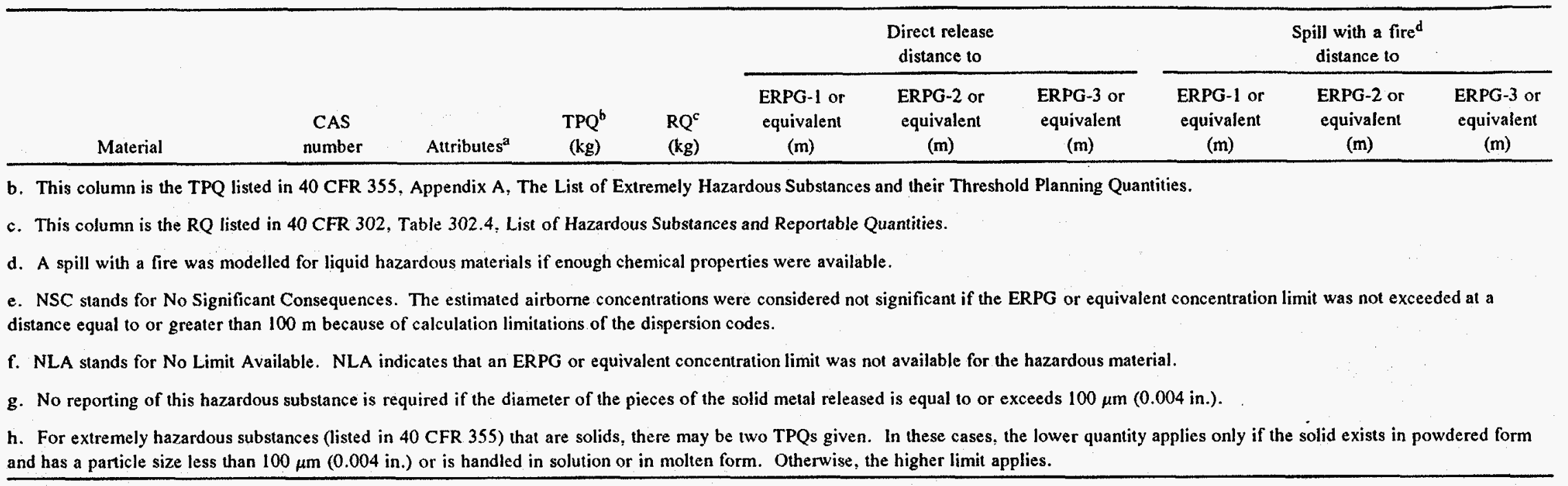


Table 4. Summary of consequence results for liquid hazardous material spills.

\begin{tabular}{|c|c|c|c|c|c|c|c|}
\hline \multirow[b]{2}{*}{ Material } & \multirow[b]{2}{*}{$\begin{array}{l}\text { CAS } \\
\text { number }\end{array}$} & \multirow[b]{2}{*}{ Attributes $^{\mathrm{a}}$} & \multirow[b]{2}{*}{$\begin{array}{c}\mathrm{TPQ}^{\mathrm{b}} \\
(\mathrm{kg})\end{array}$} & \multirow[b]{2}{*}{$\begin{array}{l}\mathrm{RQ}^{\mathrm{c}} \\
(\mathrm{kg})\end{array}$} & \multicolumn{3}{|c|}{$\begin{array}{l}\text { Spill (no fire present) } \\
\text { distance to }\end{array}$} \\
\hline & & & & & $\begin{array}{c}\text { ERPG-1 or } \\
\text { equivalent } \\
\text { (m) }\end{array}$ & $\begin{array}{c}\text { ERPG-2 or } \\
\text { equivalent } \\
\text { (m) }\end{array}$ & $\begin{array}{c}\text { ERPG-3 or } \\
\text { equivalent } \\
\text { (m) }\end{array}$ \\
\hline Acetic acid & $64-19-7$ & 1BL2SC & & 2,270 & $\mathrm{NSC}^{\mathrm{e}}$ & NSC & NSC \\
\hline Acetone & $67-64-1$ & 1BL3PF & & 2,270 & NSC & NSC & NSC \\
\hline Acrylonitrile & $107-13-1$ & 1AL3PF & 4,540 & & 425 & 298 & NSC \\
\hline Benzene & $71-43-2$ & 1BL3IF & & 4.54 & 160 & 160 & NSC \\
\hline Butanone-2 (methyl ethyl ketone) & $78-93-3$ & 2BL3SF & & 2,270 & NSC & NSC & NSC \\
\hline Carbon tetrachloride & $56-23-5$ & IBLOIN & & 4.54 & NSC & NSC & NSC \\
\hline Chlorobenzene & $108-90-7$ & 1BL3IF & & 45.4 & NSC & NSC & NSC \\
\hline Chloroform & $67-66-3$ & IALOIN & 4,540 & & NSC & NSC & NSC \\
\hline Cresol-m & $108-39-4$ & IBL2IC & & 454 & NSC & NSC & NSC \\
\hline Di-n-butylphthalate & $84-74-2$ & 2BL2IC & & 4.54 & NSC & NSC & NSC \\
\hline Dichlorobenzene-1,3 & $541-73-1$ & 3BL2IC & & 45.4 & NSC & NSC & $\operatorname{NLA}^{f}$ \\
\hline Dichlorobenzene-1,2 & $95-50-1$ & 2BL2IC & & 45.4 & NSC & NSC & NSC \\
\hline Dichloroethane-1,1 & $75-34-3$ & 1BL3PF & & 454 & NSC & NSC & NSC \\
\hline Dichloroethane-1,2 & $107-06-2$ & 2BL3IF & & 45.4 & NSC & NSC & NSC \\
\hline Dichloroethene-1,2 & $156-60-5$ & 3BL3IF & & 454 & NSC & NSC & NLA \\
\hline Dichloroethylene-1.1 & $75-35-4$ & 2BL4IF & & 45.4 & 410 & 360 & NLA \\
\hline Diethyl phthalate & $84-66-2$ & 2BL1IC & & 454 & NSC & NSC & NLA \\
\hline Ethylbenzene & $100-41-4$ & 1BL3IF & & 454 & NSC & NSC & NSC \\
\hline Ethylene diamine & $107-15-3$ & $1 \mathrm{AL} 2 \mathrm{SC}$ & 4,540 & & NSC & NSC & NSC \\
\hline Formic acid & $64-18-6$ & 1BL2SC & & 2,270 & 187 & 116 & NSC \\
\hline Hexachlorobutadiene & $87-68-3$ & 2BL11C & & 0.454 & NSC & NSC & NSC \\
\hline Hexone (methyl isobutyl ketone) & $108-10-1$ & 1BL3PF & & 2,270 & NSC & NSC & NSC \\
\hline Mercury & $7439-97-6$ & 2BLOIN & & 0.454 & NSC & NSC & NSC. \\
\hline Methanol (methyl alcohol) & $67-56-1$ & 1BL3SF & & 2,270 & NSC & NSC & NSC \\
\hline Methyl ethyl ketone (MEK) & $78-93-3$ & 1BL3SF & & 2,270 & NSC & NSC & NSC \\
\hline Methylene chloride & $75-09-2$ & 2BLIIC & & 454 & 125 & NSC & NSC \\
\hline Nitric acid & $7697-37-2$ & IALOSN & 454 & & 458 & 135 & NSC \\
\hline Nitrobenzene & $98-95-3$ & 1AL2IC & 4,540 & & NSC & NSC & NSC \\
\hline Pyridine & $110-86-1$ & 1BL3SF & & 454 & 141 & 108 & NSC \\
\hline Sulfuric acid & $7664-93-9$ & 2ALOSN & 454 & & NSC & NSC & NSC \\
\hline Tetrachloroethene & $127-18-4$ & 2BLOIN & & 45.4 & NSC & NSC & NSC \\
\hline Tetrachloroethylene & $127-18-4$ & IBLOIN & & 45.4 & NSC & NSC & NSC \\
\hline Toluene & $108-88-3$ & IBL3IF & & 454 & NSC & NSC & NSC \\
\hline Trans-1,2-dichloroethane & $107-06-2$ & 2BL3IF & & 4.54 & 320 & 190 & NSC \\
\hline Trichloroethane-1,1,1 & $71-55-6$ & 2BLIIC & & 454 & NSC & NSC & NSC \\
\hline Trichloroethene & $79-01-6$ & 2BL2IC & & 45.4 & NSC & NSC & NSC \\
\hline
\end{tabular}


Table 4. (continued).

\begin{tabular}{|c|c|c|c|c|c|c|c|}
\hline \multirow[b]{2}{*}{ Material } & \multirow[b]{2}{*}{$\begin{array}{c}\text { CAS } \\
\text { number }\end{array}$} & \multirow[b]{2}{*}{ Attributes ${ }^{\mathrm{a}}$} & \multirow[b]{2}{*}{$\begin{array}{c}\mathrm{TPQ}^{\mathrm{b}} \\
(\mathrm{kg})\end{array}$} & \multirow[b]{2}{*}{$\begin{array}{l}\mathrm{RQ}^{\mathrm{c}} \\
(\mathrm{kg})\end{array}$} & \multicolumn{3}{|c|}{$\begin{array}{l}\text { Spill (no fire present) } \\
\text { distance to }\end{array}$} \\
\hline & & & & & $\begin{array}{l}\text { ERPG-1 or } \\
\text { equivalent } \\
(\mathrm{m})\end{array}$ & $\begin{array}{l}\text { ERPG-2 or } \\
\text { equivalent } \\
\text { (m) }\end{array}$ & $\begin{array}{l}\text { ERPG-3 or } \\
\text { equivalent } \\
\text { (m) }\end{array}$ \\
\hline Trichloroethylene & $79-01-06$ & 1BL2IC & & 45.4 & NSC & NSC & NSC \\
\hline Xylene (mixed isomers) & $1330-20-7$ & 1BL3IF & & 454 & NSC & NSC & NSC \\
\hline
\end{tabular}

a. The Attributes column has a six character identifier "ABCDEF." These characters are defined as follows:

A-This position denotes if the hazardous material is 1 -in ALOHA chemical library, modeled with ALOHA

2-not in ALOHA chemical library, in EPI chemical library, modeled with EPI

3-not in ALOHA or EPI chemical library, chemical properties added to ALOHA chemical library, modeled with ALOHA

B-This position denotes if the

A-TPQ was the quantity used for the dispersion calculations

$B-R Q$ was the quantity used for the dispersion calculations

C-This position denotes the physical state of the hazardous material. $S-D e n o t e s$ that the substance is a solid at normal temperatures $L-D e n o t e s$ that the substance is a liquid at normal temperatures G-Denotes that the substance is a gas at normal temperatures

D-This position denotes the fire hazard from the National Fire Protection Association (NFPA: NFPA 325M "Fire Hazard Properties of Flammable Liquids, Gases, and Volatile Solids," 1991) codes. $0-$ Will not burn 1-Will burn at temperatures above $200^{\circ} \mathrm{F}$ 2-Will burn at temperatures above $100^{\circ} \mathrm{F}$ 3-Fire and explosion hazard at normal temperatures 4-Extremely dangerous fire and explosion hazard

E-This position denotes the solubility of the substance relative to water. I-Substance is not soluble in water $\mathrm{P}$-Substance is partially soluble in water $\mathrm{R}$-Substance reacts readily in water or air - S-Substance is soluble in water

F-This position denotes the ease with which the substance burns. F-Denotes a flammable and volatile substance C-Denotes a substance that is combustible $\mathrm{N}-$ Denotes a substance that is non combustible

b. This column is the TPQ listed in 40 CFR 355, Appendix A, The List of Extremely Hazardous Substances and their Threshold Planning Quantities.

c. This column is the RQ listed in 40 CFR 302, Table 302.4, List of Hazardous Substances and Reportable Quantities.

d. A spill was modeled for liquid hazardous materials if enough chemical properties were available.

e. NSC stands for No Significant Consequences. The estimated airborne concentrations were considered not significant if the ERPG or equivalent concentration limit was not exceeded at a distance equal to or greater than $100 \mathrm{~m}$ because of calculation limitations of the dispersion codes.

f. NLA stands for No Limit Available. NLA indicates that an ERPG or equivalent concentration limit was not available for the hazardous material. 


\section{EMERGENCY PLANNING ZONES}

The DOE Order 5500.3A guidance documents state that the results of the consequence analysis should be used to define the facility EPZ. In accordance with the guidance, the results of the consequence analysis presented in Section 5 were used to define the EPZ for WERF. The EPZ for WERF is presented in this section.

\subsection{Proposed Minimum EPZ Radius}

The proposed minimum EPZ radius for WERF was determined using the consequence results in Section 5 and the EPZ determination logic diagram provided in the DOE Order 5500.3A guidance document. As demonstrated in Section 5, the highest emergency class for operational emergencies at WERF is a Site Area Emergency. From the consequence results in Section 5, the worst-case event scenario has the potential to exceed the ESHE concentration limit (ERPG-3 or equivalent) to a distance of approximately $600 \mathrm{~m}$. Therefore, using these results and the EPZ determination logic diagram, the proposed minimum EPZ radius for WERF is $2 \mathrm{~km}$.

\subsection{Tests of Reasonableness}

Other factors should also be considered, and the size and shape of the proposed EPZ should be adjusted accordingly so that (a) the EPZ conforms to the physical and jurisdictional realities of the site and surrounding area and (b) the EPZ gives confidence that planning and preparedness will be sufficiently flexible and detailed to deal with all types and magnitudes of emergency conditions. Five significant considerations that cannot be readily stated as quantitative guidance are provided in the DOE Order 5500.3A guidance document. These five significant considerations are in the form of questions to be used as "tests of reasonableness" for the proposed EPZ size. The following five tests of reasonableness are addressed for the proposed EPZ of $2 \mathrm{~km}$ for WERF:

1. Are the maximum distances to Protective Action Guidelines (PAGs) or ERPG level impacts for most of the analyzed accident scenarios equal to or less than the EPZ radius selected?

Yes, the maximum distances to ERPG level impacts (protective action criteria ERPG-2) for almost all of the analyzed accident scenarios are equal to or less than the proposed EPZ radius. In fact, only three hazardous materials had estimated consequences that exceeded the ERPG-2 or equivalent level at a distance greater than $2 \mathrm{~km}$.

2. Is the selected EPZ radius large enough to provide for extending response activities outside the EPZ if conditions warrant?

Yes, the selected EPZ radius is large enough to provide for extending response activities outside the EPZ if conditions warrant. The agencies involved in the planning effort for response actions, including INEL security (Protection Technology Idaho), INEL Fire Department, EG\&G Idaho Medical, state and local law enforcement, regional and local hospitals, and local fire departments, are identical to those required for an extended response outside the selected EPZ. Lines of communication and decision processes involving each of these entities have been established and practiced. In exercises, the offsite agencies have demonstrated the flexibility to adapt and extend preplanned response actions to different areas, depending on the conditions of a particular scenario. 
3. Is the EPZ radius large enough to support an effective response at and near the scene of the emergency?

Yes, the EPZ radius is large enough to support an effective response at and near the scene of the emergency. The 2-km EPZ encompasses all WROC/WERF/PBF facilities and all roads leading to them. All nonessential people will be evacuated; they will not complicate or interfere with response at the scene. The control access will exclude nonessential personnel and ensure that emergency vehicles and personnel will not be impeded by nonemergency traffic.

4. Does the proposed EPZ conform to natural and jurisdictional boundaries where reasonable, and are other expectations and needs of the offsite agencies likely to be met by the selected EPZ?

There are no specific natural or jurisdictional boundaries with which to align the EPZ. However, a natural boundary may be established by using the roads that lead to the WROC/WERF/PBF facilities. Also, the consequences do not exceed protective action criteria that will require the assistance of offsite agencies. However, if offsite agency assistance is necessary, exercises have demonstrated the flexibility of offsite agencies to adapt and extend preplanned response actions to different areas.

5. What enhancement of the facility and site boundary preparedness stature would be achieved by increasing the selected EPZ radius?

The proposed EPZ radius already ensures the involvement and integration of all essential emergency response personnel. No enhancement would be gained by increasing the selected EPZ.

\subsection{Minimum EPZ Radius}

Based on the results of the reasonableness tests, the proposed EPZ is reasonable and no adjustments are needed. Therefore, the minimum EPZ radius for operational emergencies at the WERF is $2 \mathrm{~km}$, as shown in Figure 5. 


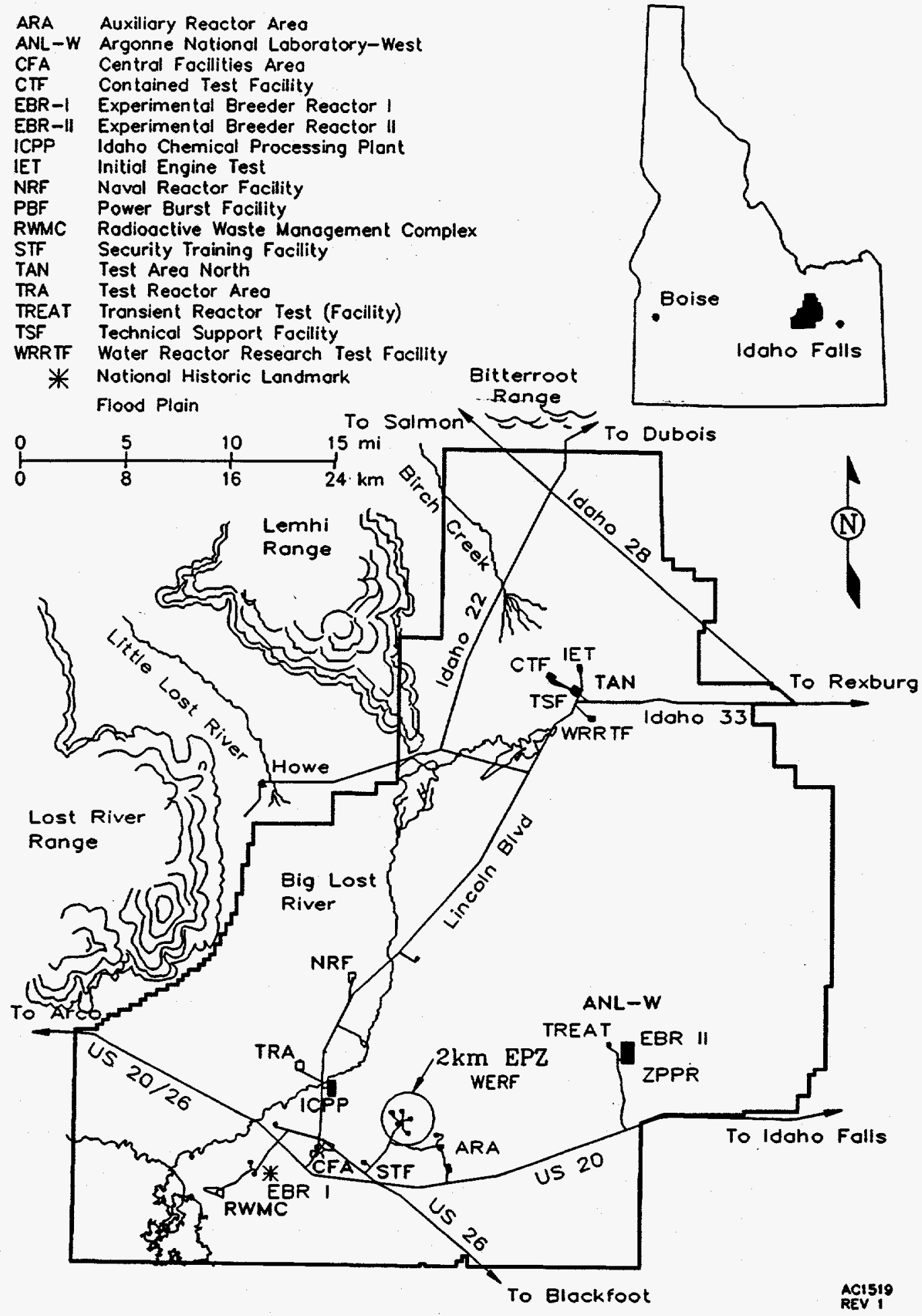

Figure 5. The Minimum EPZ for WERF. 


\section{EMERGENCY CLASSES, PROTECTIVE ACTIONS, AND EMERGENCY ACTION LEVELS}

Because the specific type of hazardous material involved in an event scenario may not be readily known, it must be assumed that the material having the highest consequences is involved for a particular event scenario. For the two event scenarios analyzed, the consequence results indicated that the highest emergency class for both event scenarios is a Site Area Emergency. The EALs and protective actions for both event scenarios are presented by severity of the analyzed event scenarios.

\subsection{Site Area Emergency EALs}

From the analysis in Section 5, the following possible EALs are identified for a Site Area Emergency:

- A fire in the WWSB that is not mitigated within a 10 minutes of detection.

Basis: A fire in the WWSB has the potential to release hazardous materials that are stored as solids, liquids, or gases. If the fire is mitigated quickly, the release of hazardous materials will be limited. If the fire cannot be mitigated rapidly, the facility limit of liquid hazardous materials could be volatized. If the fire persists, there is the potential to release the facility limit of any of the hazardous materials stored in the WWSB.

- Puncture, fracture, or rupture of a container that contains a liquid hazardous material.

Basis: There may be no means to identify the specific liquid hazardous material spilled. Therefore, it must be assumed that the facility limit quantity of the most hazardous material was released.

\subsection{Site Area Emergency Protective Actions}

Protective actions must to be taken for both types of event scenarios analyzed: (a) a fire in the WWSB or (b) a liquid hazardous material spill. The protective actions for the analyzed event scenarios are discussed below.

\subsubsection{Protective Actions for a Fire in the WWSB}

Protective actions to protect personnel at the WROC/WERF/PBF area will be required if a fire occurs at the WWSB. If a fire occurs at the WWSB and it cannot be mitigated within 10 minutes, actions should be taken to evacuate all personnel to a distance greater than $2 \mathrm{~km}$ from WERF. This means that all personnel at the WROC/WERF/PBF area should be evacuated.

All personnel should be evacuated because a fire at the WWSB has the potential to release significant quantities of hazardous materials stored at the facility. The hazardous materials released in a fire may produce ERPG-3 or equivalent concentrations out to a distance of approximately $600 \mathrm{~m}$.

\subsubsection{Protective Actions for a Liquid Hazardous Material Spill}

Protective actions to protect personnel in the immediate vicinity of WERF will be required if liquid hazardous materials are spilled at the WWSB. If possible, protective actions for treatment of 
the spill should be initiated immediately to limit the amount of hazardous material released. All personnel at WERF should be evacuated to a distance greater than $500 \mathrm{~m}$ away from WERF.

Personnel at other facilities located at the WROC/WERF/PBF area will not be affected by this event. 


\section{MAINTENANCE AND REVIEW OF THIS HAZARDS ASSESSMENT}

The WERF Management is responsible for ensuring the WERF hazards assessment is regularly reviewed and maintained current. The review requirement and schedule is specified in the Site Emergency Readiness Assurance Plan. The current schedule requires the hazards assessment to be reviewed annually.

The WERF HA is a controlled document and is subject to Configuration Control. Configuration Control is the process of managing and controlling changes to baseline configuration items to ensure that changes are adequately defined, evaluated, reviewed, and approved. At WERF, a Configuration Management $(\mathrm{CM})$ coordinator has been assigned to coordinate the disciplined implementation of configuration management. The CM coordinator is knowledgeable of WERF systems, components, and documents and ensures that changes are managed in accordance with approved procedures. The $\mathrm{CM}$ coordinator identifies the change that needs to be made, ensures that proper review and approval is obtained, ensures that other affected documentation is identified, and follows up to ensure that the change has been implemented. Changes to facility documentation and equipment are documented in Drawing Revision Requests, Document Change Notices, and Facility Change Forms. The Unreviewed Safety Question ${ }^{19}$ (USQ) process interfaces with CM through Drawing Revision Requests, Document Change Notices, and Facility Change Forms. These items implement the requirement to perform a USQ evaluation as a part of the change control process. 


\section{REFERENCES}

1. U.S. Department of Energy, Office of Emergency Preparedness and Response and Office of Emergency Planning and Operations, "Emergency Management Guidance," memorandum to Distribution, June 29, 1992.

2. J. A. Jones, Chief Occupational Safety and Emergency Management Branch DOE-ID, To Contractor Distribution, Subject: "Issuance of Hazards Assessment Guidance - AM/SES-OEM92-206," October 7, 1992.

3. DOE Order 5500.3A, "Planning and Preparedness for Operational Emergencies," April 30, 1991.

4. Site Development Plan, Idaho National Engineering Laboratory, prepared for the U.S. Department of Energy by EG\&G Idaho, Inc., November 1990.

5. Waste Experimental Reduction Facility Safety Analysis Report, WM-F1-81-026, Revision 8, EG\&G Idaho, Inc., August 1994.

6. Office of Environmental Guidance, Environmental Guidance Program Reference Book: Resource Conservation and Recovery Act, prepared for Assistant Secretary for Environment, Safety, and Health by Oak Ridge National Laboratory, ORNL/M-1897, B/A No. HA 011500 0;EHHAOO2, March 15, 1992.

7. 40 CFR 261, Appendix II, "Method 1311 - Toxicity Characteristic Leaching Procedure," Code of Federal Regulations Chapter 40, Part 261, July 1, 1992.

8. J. K. Knudsen, Hazards Assessment for the Waste Engineering Development Facility, (DRAFT), May 1993.

9. M. B. Calley et al., Hazards Assessment for the Mixed Waste Storage Facility and Mixed Waste Storage Facility Portable Storage Units at the Waste Reduction Operations Complex, EGGWROC-11153, (DRAFT), February 1994.

10. J. L. Edson and T. W. Bolander, Hazards Assessment for the PBF Reactor Facility, PG-T-93011, (DRAFT), March 1993.

11. M. B. Calley, Hazards Assessment for the Water Treatment Facilities at the Waste Reduction Operations Complec, ER\&WM-WROC-94-015, (DRAFT), June 1994.

12. Environmental Restoration and Waste Management Emergency Plan/RCRA Contingency Plan, EG\&G Idaho, Inc., January 1994.

13. Chemical Emergency Preparedness and Prevention Office, Areal Locations of Hazardous Atmospheres (ALOHA), Version 5.1, Environmental Protection Agency, December 1990.

14. Human Association Inc., Emergency Prediction Information (EPI) code, Version 5.0, 1993.

15. Chemical Emergency Preparedness and Prevention Office, Computer-Aided Management of Emergency Operations, Version 1.0, Environmental Protection Agency, December 1990. 
16. Memorandum from G.E. Start, U.S. Department of Commerce National Oceanic and Atmospheric Administration, to Jerry Edson, EG\&G Idaho, Inc., "Reference meteorological values for PBF dispersion calculations," January 22, 1993.

17. P. R. Leonard, Formal Documentation of 1987-1991 INEL Wind Files Used in CAP-88, EG\&G Idaho, Inc., EDF-CAP-PROT-91-011, February 12, 1992.

18. Letter from W. S. Schum, EG\&G Idaho, Inc., to Distribution, "ERPG/EAL Information," June 25, 1993.

19. U.S. Department of Energy, "Unreviewed Safety Questions," DOE Order 5480.21, December 24, 1991. 


\section{Appendix A}

\section{WERF Hazardous Commercial Material List}



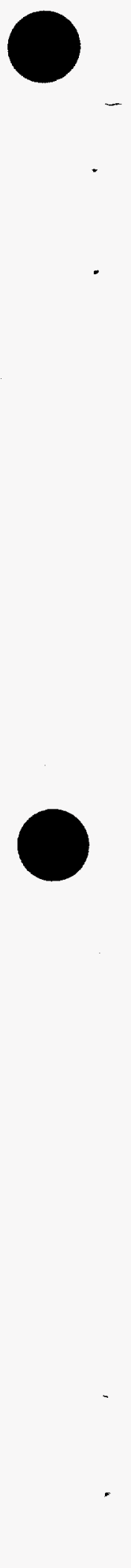


\section{Appendix A}

\section{WERF Hazardous Commercial Material List}

The nonradiological hazardous materials that are commercial products have been identified at WERF. This appendix contains an inventory of the products located at WERF as of June 16, 1994. 
Table A-1. WERF hazardous commercial product list.

\begin{tabular}{|c|c|c|c|c|c|c|c|c|c|}
\hline Chemical & Trade Name & Manufacturer & Location $^{\mathrm{a}}$ & Description & $\begin{array}{l}\text { Typical } \\
\text { Quantity } \\
\end{array}$ & $\begin{array}{l}\text { MSDS } \\
\mathrm{Y} / \mathrm{N}\end{array}$ & $\begin{array}{l}\text { Shelf } \\
\text { Life }\end{array}$ & $\begin{array}{l}\text { EXP. } \\
\text { Date }\end{array}$ & $\begin{array}{l}\text { SARA } \\
\mathrm{Y} / \mathrm{N}\end{array}$ \\
\hline $\begin{array}{l}\text { 02001 Electrical Cleaner } \\
\text { (aerosol) }\end{array}$ & & Sherwin Williams & $\begin{array}{l}\text { Per } 609 \text { FSC } \\
\text { RM109 }\end{array}$ & Compounded Product & $160 \mathrm{oz}$ & $\mathrm{Y}$ & $\mathrm{N} / \mathrm{A}$ & $\mathrm{N} / \mathrm{A}$ & \\
\hline $15 w 40$ Engine Oil & & Cummins Engine Co. & Per 609 RMB 102 & Compounded Product & $9 \mathrm{gal}$ & $\mathrm{Y}$ & $\mathrm{N} / \mathrm{A}$ & $\mathrm{N} / \mathrm{A}$ & \\
\hline 2-Propanol & & Fisher Chem/various & $\begin{array}{l}\text { Per } 609 \text { FSC } \\
\text { RM109 }\end{array}$ & Propanol & $2 \mathrm{pts}$ & $\mathbf{Y}$ & $\mathrm{N} / \mathrm{A}$ & $\mathrm{N} / \mathrm{A}$ & \\
\hline 230 Latex/Silicone & Sealant & Dap & $\begin{array}{l}\text { Per } 609 \text { NFPS } \\
\text { RMB107 }\end{array}$ & Compounded Product & $93 \mathrm{oz}$ & $\mathrm{Y}$ & $\mathrm{N} / \mathrm{A}$ & N/A & \\
\hline 300 Flow Plus & & Schaffers Mfg. & $\begin{array}{l}\text { Per } 609 \text { FSC } \\
\text { RM } 109\end{array}$ & Compounded Product & $4 \mathrm{qt}$ & $Y$ & N/A & N/A & $\mathbf{N}$ \\
\hline 321 Dry Film Lubricant & & Dow Corning & Per 609 RM109 & Compounded Product & $1 \mathrm{gal}$ & $\mathrm{Y}$ & N/A & N/A & \\
\hline $\begin{array}{l}4 \text { Compound (Insulating } \\
\text { Paste/Compound }\end{array}$ & & Dow Corning Corp. & Per 609 RMB102 & Compounded Product & $6 \mathrm{oz}$ & $\mathrm{Y}$ & N/A & N/A & $\mathbf{Y}$ \\
\hline 736 Heat Resistant Silicone & RTV Sealant & Dow Corning & $\begin{array}{l}\text { Per } 609 \text { FSC } \\
\text { RM109 }\end{array}$ & Compounded Product & $124 \mathrm{oz}$ & $\mathrm{Y}$ & N/A & N/A & \\
\hline 999-A Silicone & RTV Sealant & Dow Corning & Per 609 RMI09 & Compounded Product & $371 \mathrm{oz}$ & $\mathrm{Y}$ & $\mathrm{N} / \mathrm{A}$ & N/A & \\
\hline A.W. Hydraulic 220 & & Chevron & Per 609 RMB 102 & Compounded Product & $5 \mathrm{gal}$ & $\mathrm{Y}$ & $\mathrm{N} / \mathrm{A}$ & N/A & $\mathrm{N}$ \\
\hline A.W. Machine Oil 220 & & Chevron & Per 609 RMB102 & Compounded Product & $5 \mathrm{gal}$ & $\mathbf{Y}$ & $N / A$ & N/A & $\mathrm{N}$ \\
\hline Acetylene & & Various & Per 635 & $100 \%$ Acetylene & $250 \mathrm{lbs}$ & $\mathrm{Y}$ & N/A & N/A & $\mathrm{N}$ \\
\hline Aerodag G (aerosol) & & Various & $\begin{array}{l}\text { Per } 609 \text { FSC } \\
\text { RMI09 }\end{array}$ & Compounded Product & $156 \mathrm{oz}$ & $\mathrm{Y}$ & N/A & N/A & $\mathbf{Y}$ \\
\hline Air tool ludricant & & Hilti Fastening Systems & $\begin{array}{l}\text { Per } 609 \text { FSC } \\
\text { RM109 }\end{array}$ & Compounded Product & $12 \mathrm{oz}$ & $\mathrm{Y}$ & N/A & N/A & \\
\hline Ajax & & Colgate palmolive & $\begin{array}{l}\text { Per } 609 \text { CCS \& } \\
\text { RM116 }\end{array}$ & Compounded Product & $546 \mathrm{oz}$ & $\mathrm{Y}$ & N/A & N/A & $\mathrm{N}$ \\
\hline Ammonium Phosphate & $A B C$ extinguisher & Various & Various & $\begin{array}{l}100 \% \text { Ammonium } \\
\text { Phosphate }\end{array}$ & $300 \mathrm{lbs}$ & $\mathbf{Y}$ & N/A & N/A & $\mathbf{N}$ \\
\hline $\begin{array}{l}\text { Anti-Static Spray } 6625 \\
\text { (aerosol) }\end{array}$ & & Inmas Corp. & Per 609 RMB102 & Compounded Product & $14 \mathrm{oz}$ & $\mathbf{Y}$ & N/A & N/A & $\mathbf{N}$ \\
\hline $\begin{array}{l}\text { Anti-Static Spray } 9040 \\
\text { (aerosol) }\end{array}$ & & $\begin{array}{l}\text { Crown Industrial } \\
\text { Products Co. Inc. }\end{array}$ & Per 609 RMB 102 & Compounded Product & $15 \mathrm{oz}$ & $\mathbf{Y}$ & N/A & N/A & $\mathbf{N}$ \\
\hline
\end{tabular}


Table A-1. (continued).

\begin{tabular}{|c|c|c|c|c|c|c|c|c|c|c|}
\hline Chemical & Trade Name & Manufacturer & Location $^{\mathrm{a}}$ & Description & $\begin{array}{l}\text { Typical } \\
\text { Quantity }\end{array}$ & $\begin{array}{l}\text { MSDS } \\
\text { Y/N }\end{array}$ & $\begin{array}{l}\text { Shelf } \\
\text { Life }\end{array}$ & $\begin{array}{l}\text { EXP. } \\
\text { Date }\end{array}$ & $\begin{array}{l}\text { SARA } \\
\text { Y/N }\end{array}$ & \\
\hline Backing Soda & & Arm \& Hammer & Per 609 CCS & Compounded Product & $240 \mathrm{oz}$ & $\mathbf{Y}$ & $N / A$ & N/A & & \\
\hline Baking Soda & & Arm \& Hammer & CCS \& RMB102 & Compounded Product & $320 \mathrm{oz}$ & $\mathrm{Y}$ & $\mathrm{N} / \mathrm{A}$ & N/A & $\mathrm{N}$ & \\
\hline Body Shampoo & & Santi Fresh & Per 609 RMII6 & Compounded Product & $486 \mathrm{oz}$ & $\mathbf{Y}$ & N/A & N/A & & \\
\hline Body Shampoo & & Johnson Wax & Per 609 RM1 16 & Compounded Product & $92 \mathrm{oz}$ & $\mathbf{Y}$ & N/A & N/A & & \\
\hline Bounce Back & & Spartan & Per 609 RM104 & Compounded Product & $3 \mathrm{gal}$ & $\mathbf{Y}$ & $\mathrm{N} / \mathrm{A}$ & $\mathrm{N} / \mathrm{A}$ & & \\
\hline Bounce Back & & Spartan & Per 609 CCS & Compounded Product & $7 \mathrm{gal}$ & $\mathbf{Y}$ & N/A & N/A & & \\
\hline Brasso & & Airwick Indusrties & $\begin{array}{l}\text { Per } 609 \text { CS } \\
\text { RM116 }\end{array}$ & Compounded Product & $8 \mathrm{oz}$ & $\mathbf{Y}$ & N/A & N/A & $\mathbf{N}$ & \\
\hline Cam 2 EP $80 w 90$ & & Cam 2 oil Products & Per 609 RMB 102 & Compounded Product & 5 gal & $\mathbf{Y}$ & N/A & N/A & & \\
\hline Carbon Monoxide & & Various & Per 609 RM101 & Compounded Product & $500 \mathrm{lbs}$ & $\mathbf{Y}$ & N/A & N/A & $\mathbf{Y}$ & \\
\hline Carbon Zine Batteries & & Various & Various & Compounded Product & Various & $\mathbf{Y}$ & N/A & N/A & $\mathrm{N}$ & \\
\hline Carbon Dioxide & & Various & Various & $100 \%$ Carbon dioxide & $30 \mathrm{lbs}$ & $\mathbf{Y}$ & $\mathrm{N} / \mathrm{A}$ & N/A & $\mathrm{N}$ & \\
\hline Carpet Protector & & 3M Center & $\begin{array}{l}\text { Per } 609 \text { CS } \\
\text { RM } 116\end{array}$ & Compounded Product & $6 \mathrm{gal}$ & $\mathbf{Y}$ & N/A & $\mathrm{N} / \mathrm{A}$ & $Y$ & \\
\hline Citro-Shield (aerosol) & Furniture polish & Spartan Chemical Co. & $\begin{array}{l}\text { Per } 609 \text { CS } \\
\text { RM104 }\end{array}$ & Compounded Product & $18 \mathrm{oz}$ & $\mathbf{Y}$ & N/A & N/A & $N$ & \\
\hline Clean Gear 747 & & $\begin{array}{l}\text { Georgia Steel \& } \\
\text { Chemical Co. }\end{array}$ & Per 609 RMB 102 & Compounded Product & $96 \mathrm{oz}$ & $\mathrm{Y}$ & N/A & $\mathrm{N} / \mathrm{A}$ & $\mathrm{Y}$ & m \\
\hline $\begin{array}{l}\text { Coating-Clear Water } \\
\text { Repellent }\end{array}$ & WaterSeal & $\begin{array}{l}\text { Thompson\& Formby } \\
\text { Inc. }\end{array}$ & $\begin{array}{l}\text { Per } 609 \text { FSC } \\
\text { RM } 109\end{array}$ & $90 \%$ Mineral Spirits & $1 q t$ & $\mathbf{Y}$ & N/A & $\mathrm{N} / \mathrm{A}$ & $\mathrm{N}$ & $\frac{1}{\frac{1}{3}} \frac{N}{2}$ \\
\hline Columbia 07-785-CC & & Columbia Paint Co. & $\begin{array}{l}\text { Per } 609 \text { FSC } \\
\text { RM109 }\end{array}$ & Compounded Product & $1 \mathrm{gal}$ & $\mathbf{Y}$ & $3 y r s$. & $3 / 95$ & $\mathrm{~N}$ & 点密 \\
\hline Columbia 07-590-NT & & Columbia Paint Co. & $\begin{array}{l}\text { Per } 609 \text { FSC } \\
\text { RM } 109\end{array}$ & Compounded Product & $1 \mathrm{gal}$ & $\mathbf{Y}$ & N/A & N/A & $\mathrm{N}$ & 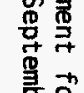 \\
\hline Complete Floor Wax & & S.C. Johnson Wax & Per 609 CCS & Compounded Product & $5 \mathrm{gal}$ & $\mathbf{Y}$ & $\mathrm{N} / \mathrm{A}$ & N/A & $\mathbf{Y}$ & $\begin{array}{l}07 \\
7 \rightarrow+4\end{array}$ \\
\hline $\begin{array}{l}\text { Compublend } 11 \text { Heavy Duty } \\
\text { Cleaner }\end{array}$ & & 3M Center & $\begin{array}{l}\text { Per } 609 \mathrm{CS} \\
\text { RM116 }\end{array}$ & Compounded Product & $5 \mathrm{gal}$ & $\mathbf{Y}$ & N/A & N/A & $\mathbf{Y}$ & 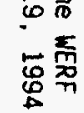 \\
\hline
\end{tabular}


Table A-1. (continued).

\begin{tabular}{|c|c|c|c|c|c|c|c|c|c|}
\hline Chemical & Trade Name & Manufacturer & Location $^{\mathbf{a}}$ & Description & $\begin{array}{l}\text { Typical } \\
\text { Quantity }\end{array}$ & $\begin{array}{l}\text { MSDS } \\
\mathrm{Y} / \mathrm{N}\end{array}$ & $\begin{array}{l}\text { Shelf } \\
\text { Life }\end{array}$ & $\begin{array}{l}\text { EXP. } \\
\text { Date }\end{array}$ & $\begin{array}{l}\text { SARA } \\
\text { Y/N }\end{array}$ \\
\hline $\begin{array}{l}\text { Compublend II Disinfectant } \\
\text { (pre mixed) }\end{array}$ & & 3M Center & $\begin{array}{l}\text { Per } 609 \text { CS } \\
\text { RM1 } 16\end{array}$ & Compounded Product & 5 gal & $\mathrm{Y}$ & N/A & N/A & $\mathrm{Y}$ \\
\hline Compublend II Disinfectant & & $3 \mathrm{M}$ Center & $\begin{array}{l}\text { Per } 609 \text { CS } \\
\text { RM } 116\end{array}$ & Compounded Product & $1 \mathrm{gal}$ & $\mathbf{Y}$ & N/A & N/A & $\mathrm{Y}$ \\
\hline $\begin{array}{l}\text { Compublend } 2 \text { Spot \& } \\
\text { Stain Remover }\end{array}$ & & 3M Center & Per 609 RM116 & Compounded Product & $5 \mathrm{gal}$ & $\mathbf{Y}$ & N/A & N/A & \\
\hline $\begin{array}{l}\text { Compublend } 2 \text { Shampoo } \\
\text { Spray Clearner }\end{array}$ & & 3M Center & Per 609 RM1 16 & Compounded Product & $5 \mathrm{gal}$ & $\mathbf{Y}$ & N/A & N/A & \\
\hline $\begin{array}{l}\text { Compublend } 11 \text { Neutral } \\
\text { Cleaner }\end{array}$ & & $3 \mathrm{M}$ Center & $\begin{array}{l}\text { Per } 609 \text { CS } \\
\text { RM116 }\end{array}$ & Compounded Product & 5 gal. & $\mathbf{Y}$ & N/A & N/A & $\mathbf{Y}$ \\
\hline $\begin{array}{l}\text { Compublend } 11 \text { Glass } \\
\text { Cleaner }\end{array}$ & & 3M Center & $\begin{array}{l}\text { Per } 609 \text { CS } \\
\text { RM116 }\end{array}$ & Compounded Product & $5 \mathrm{gal}$ & $\mathbf{Y}$ & N/A & N/A & $\mathrm{Y}$ \\
\hline $\begin{array}{l}\text { Conoco Motor oil (in hand } \\
\text { pump cans) }\end{array}$ & $20-20$ & Conoco & $\begin{array}{l}\text { Per } 609 \text { FSC } \\
\text { RM116 }\end{array}$ & Compounded Product & $32 \mathrm{oz}$ & $\mathbf{Y}$ & N/A & N/A & $\mathrm{N}$ \\
\hline Conqu-R-Dust & & S.C. Johnson Wax & $\begin{array}{l}\text { Per } 609 \text { FSC } \\
\text { RM109 }\end{array}$ & Compounded Product & $1 \mathrm{gal}$ & $\mathbf{Y}$ & N/A & N/A & $\mathrm{Y}$ \\
\hline Cutting Oil \#208 & & Sprayon & $\begin{array}{l}\text { Per } 609 \text { FSC } \\
\text { RM109 }\end{array}$ & Compounded Product & $60 \mathrm{oz}$ & $\mathbf{Y}$ & N/A & N/A & $\mathrm{N}$ \\
\hline Defoamer & & Spartan & Per 609 RMI16 & Compounded Product & 2 gal & $\mathbf{Y}$ & N/A & N/A & \\
\hline Diesel Fuel Oil No.2-D & & Various & Per 705 & Compounded Product & $4,000 \mathrm{gal}$ & $\mathbf{Y}$ & N/A & N/A & $\mathrm{N}$ \\
\hline Diesel Fuel Oil No.2-D & & Various & Per 711 & Compounded Product & $500 \mathrm{gal}$ & $\mathbf{Y}$ & $\mathrm{N} / \mathrm{A}$ & N/A & $\mathbf{N}$ \\
\hline $\begin{array}{l}\text { Dow Corning } 111 \\
\text { Compound }\end{array}$ & Silicone Grease & Dow Corning & Per 609 RMB102 & Amorphous Silica & $11 \mathrm{oz}$ & $\mathbf{Y}$ & N/A & N/A & $\mathrm{N}$ \\
\hline Dy Chek Penetrant (aerosol) & & Turco Products & $\begin{array}{l}\text { Per } 609 \text { FSC } \\
\text { RM109 }\end{array}$ & Compounded Product & $12 \mathrm{oz}$ & $\mathbf{Y}$ & N/A & $\mathrm{N} / \mathrm{A}$ & \\
\hline $\begin{array}{l}\text { Dy Chek Remover \#3 } \\
\text { (aerosol) }\end{array}$ & & Turco Products & $\begin{array}{l}\text { Per } 609 \text { FSC } \\
\text { RM109 }\end{array}$ & Compounded Product & $7 \mathrm{oz}$ & $\mathbf{Y}$ & N/A & N/A & \\
\hline $\begin{array}{l}\text { Dy Chek Developer } \\
\text { (aerosol) }\end{array}$ & & Turco Products & $\begin{array}{l}\text { Per } 609 \text { FSC } \\
\text { RM109 }\end{array}$ & Compounded Product & $13 \mathrm{oz}$ & $\mathbf{Y}$ & N/A & N/A & \\
\hline Dyco & ice melter & Dyco Chemical & Per 609 CCS & Compounded Product & $75 \mathrm{lbs}$ & $\mathbf{Y}$ & $\mathrm{N} / \mathrm{A}$ & N/A & $\mathbf{N}$ \\
\hline
\end{tabular}


Table A-1. (continued).

\begin{tabular}{|c|c|c|c|c|c|c|c|c|c|}
\hline Chemical & Trade Name & Manufacturer & Location $^{\mathrm{a}}$ & Description & $\begin{array}{l}\text { Typical } \\
\text { Quantity }\end{array}$ & $\begin{array}{l}\text { MSDS } \\
\mathrm{Y} / \mathrm{N}\end{array}$ & $\begin{array}{l}\text { Shelf } \\
\text { Life }\end{array}$ & $\begin{array}{l}\text { EXP. } \\
\text { Date }\end{array}$ & $\begin{array}{l}\text { SARA } \\
\text { Y/N }\end{array}$ \\
\hline Eletrical Cleaner aerosol & & Sprayon Products & Per 609 & Compounded Product & $160 \mathrm{oz}$ & $\mathrm{Y}$ & $\mathrm{N} / \mathrm{A}$ & N/A & $\mathrm{N}$ \\
\hline $\begin{array}{l}\text { Enhance Lotionized Hand } \\
\text { Soap }\end{array}$ & & S.C. Johnson Wax & $\begin{array}{l}\text { Per } 609 \text { CS } \\
\text { RM116 }\end{array}$ & Compounded Product & $166 \mathrm{oz}$ & $\mathrm{Y}$ & $\mathrm{N} / \mathrm{A}$ & $\mathrm{N} / \mathrm{A}$ & $\mathrm{N}$ \\
\hline Envy (Aerosol) & & S.C.Johonson Wax & $\begin{array}{l}\text { Per } 609 \text { CS } \\
\text { RM116 }\end{array}$ & Compounded Product & $60 \mathrm{oz}$ & $\mathrm{Y}$ & $\mathrm{N} / \mathrm{A}$ & $\mathrm{N} / \mathrm{A}$ & $\mathbf{N}$ \\
\hline EP Polyurea Grease 1 & & Chevron & Per 609 RMB 102 & Compounded Product & 5 gal & $\mathrm{Y}$ & N/A & $\mathrm{N} / \mathrm{A}$ & $\mathbf{N}$ \\
\hline Elhyl Alcohol & & Vạious & $\begin{array}{l}\text { Per } 609 \text { FSC } \\
\text { RM109 }\end{array}$ & $\begin{array}{l}\text { Ethyl alcohol, } \\
\text { Anhydrous water }\end{array}$ & $1 q t$ & $Y$ & N/A & N/A & $\mathrm{Y}$ \\
\hline Ethylene Glycol & & Texaco & Per 609 CCS & Compounded Product & $2 \mathrm{gal}$ & $\mathbf{Y}$ & N/A & N/A & \\
\hline Ethylene Glycol & & Various & Per 609 RMB 102 & Ethylene Glycol & $10 \mathrm{gal}$ & $\mathbf{Y}$ & N/A & N/A & $\mathrm{Y}$ \\
\hline Expo White Board Cleaner & & Sanford & Various & Compounded Product & Various & $Y$ & N/A & N/A & $\mathbf{N}$ \\
\hline F-matic P-type & Air freshener & Eikosha Co. Ltd. & $\begin{array}{l}\text { Per } 609 \mathrm{CS} \\
\text { RM116 }\end{array}$ & Compounded Product & $20 \mathrm{oz}$ & $\mathrm{Y}$ & N/A & $\mathrm{N} / \mathrm{A}$ & $\mathrm{Y}$ \\
\hline Fel-Pro C5-A & Antiseize & Fel-Pro Inc. & Per 609 RMB102 & Compounded Product & $16 \mathrm{oz}$ & $\mathrm{Y}$ & N/A & N/A & $\mathbf{N}$ \\
\hline Fire Clay Plastic Refactory & & A.P.Green & Per 609 CCS & Compounded Product & $20 \mathrm{lbs}$ & $\mathrm{Y}$ & N/A & $\mathrm{N} / \mathrm{A}$ & \\
\hline $\begin{array}{l}\text { Flame Control Coating } \\
\text { Reducer }\end{array}$ & $\therefore$ & $\begin{array}{l}\text { Flame Control Coating } \\
\text { Inc. }\end{array}$ & $\begin{array}{l}\text { Per } 609 \text { FSC } \\
\text { RM109. }\end{array}$ & Compounded Product & $0.5 \mathrm{gal}$ & $\mathrm{Y}$ & N/A & $\mathrm{N} / \mathrm{A}$ & $\mathrm{Y}$ \\
\hline $\begin{array}{l}\text { Fox Valley Traffic Paint } \\
\text { (aerosol) }\end{array}$ & & Fox Valley System Inc. & $\begin{array}{l}\text { Per } 609 \text { FSC } \\
\text { RM109 }\end{array}$ & Compounded Product & $234 \mathrm{oz}$ & $\mathrm{Y}$ & N/A & N/A & $\mathrm{Y}$ \\
\hline Fuller O'Brien 214-10 & & The $O^{\prime}$ Brien Corp. & $\begin{array}{l}\text { Per } 609 \text { NFPS } \\
\text { RMB107 }\end{array}$ & Compounded Product & $3 \mathrm{gal}$ & $\mathrm{Y}$ & $3 y r s$. & $4 / 94$ & $\mathbf{N}$ \\
\hline Fulfer $O^{\prime}$ Brien 214-10 & & Fuller O'Brien & $\begin{array}{l}\text { Per } 609 \text { NFPS } \\
\text { RMB107 }\end{array}$ & Compounded Product & $4 \mathrm{gal}$ & $\mathbf{Y}$ & N/A & $\mathrm{N} / \mathrm{A}$ & \\
\hline Fun Dish Soap & & Eco & Per 609 RM116 & Compounded Product & $4 \mathrm{qt}$ & $\mathbf{Y}$ & N/A & N/A & \\
\hline Gasoila & Pipe fitting seal & Fedral Process Co. & Per609 RMB107 & Compounded Product & $8 \mathrm{oz}$ & $\mathbf{Y}$ & N/A & N/A & $\mathbf{N}$ \\
\hline Gasoline Unleaded & & Various & $\begin{array}{l}\text { Per } 609 \text { RM } 109 \\
(5 \text { gal can) }\end{array}$ & Compounded Product & $1 \mathrm{gal}$ & $\mathbf{Y}$ & N/A & N/A & $\mathbf{N}$ \\
\hline
\end{tabular}


Table A-1. (continued).

\begin{tabular}{|c|c|c|c|c|c|c|c|c|c|}
\hline Chemical & Trade Name & Manufacturer & Location $^{\mathrm{a}}$ & Description & $\begin{array}{l}\text { Typical } \\
\text { Quantity }\end{array}$ & $\begin{array}{l}\text { MSDS } \\
\mathrm{Y} / \mathrm{N}\end{array}$ & $\begin{array}{l}\text { Shelf } \\
\text { Life }\end{array}$ & $\begin{array}{l}\text { EXP. } \\
\text { Date }\end{array}$ & $\begin{array}{l}\text { SARA } \\
\text { Y/N }\end{array}$ \\
\hline GC Bond (rubber Cement) & & GC Electronics & $\begin{array}{l}\text { Per } 609 \text { FSC } \\
\text { RM109 }\end{array}$ & Compounded Product & $24 \mathrm{oz}$ & $\mathrm{Y}$ & N/A & N/A & $\mathrm{N}$ \\
\hline Gear Compounded EP & & Texaco & Per 609 RM 109 & Compounded Product & $5 \mathrm{gal}$ & $\mathrm{Y}$ & N/A & N/A & \\
\hline $\begin{array}{l}\text { Gear Compound } 320 \text { ISU } \\
\text { EP }\end{array}$ & & Chevron & Per 609 RM109 & Compounded Product & 5 gal & $\mathbf{Y}$ & N/A & N/A & \\
\hline $\begin{array}{l}\text { Gear Compound EP ISO } \\
460\end{array}$ & & Chevron & Per 609 RMBl02 & Compounded Product & 5 gal & $\mathrm{Y}$ & N/A & N/A & \\
\hline Genuine Sullair $24 \mathrm{KT}$ & & Sullair & $\begin{array}{l}\text { Per } 609 \text { FSC } \\
\text { RM109 }\end{array}$ & Compounded Product & $10 \mathrm{gal}$ & $\mathrm{Y}$ & N/A & N/A & \\
\hline Halon 1301 & & Various & Per 609 RM101 & $\begin{array}{l}\text { Trifiuoromonobromomet } \\
\text { hane }\end{array}$ & $200 \mathrm{lbs}$ & $\mathrm{Y}$ & N/A & N/A & $\mathrm{Y}$ \\
\hline Hand Cream & & Santi Fresh & Per 609 RMI 16 & Compounded Product & $55 \mathrm{oz}$ & $\mathrm{Y}$ & N/A & N/A & \\
\hline Hand Cream & & Sani-Fresh & $\begin{array}{l}\text { Per } 609 \text { CS } \\
\text { RM116 }\end{array}$ & Compounded Product & Various & $\mathbf{Y}$ & N/A & N/A & $\mathbf{N}$ \\
\hline Heavy Duty Cleaner & & Santi Fresh & Per 609 RM116 & Compounded Product & $432 \mathrm{oz}$ & $\mathbf{Y}$ & N/A & N/A & \\
\hline Houghto-Safe 620 & Hydraulic Fluid & E.F.Houghton \& Co. & $\begin{array}{l}\text { Per } 609 \text { RMB102 } \\
\text { \& Various }\end{array}$ & Compounded Product & $\begin{array}{l}60 \mathrm{gal} \\
255 \mathrm{gal} \\
\text { plant system }\end{array}$ & $\mathrm{Y}$ & $\mathrm{N} / \mathrm{A}$ & $\mathrm{N} / \mathrm{A}$ & $\mathrm{Y}$ \\
\hline Hydrogen Chloride Gas & & Various & $\begin{array}{l}\text { Per } 609 \text { RM101 } \\
\text { \& RM109 }\end{array}$ & Compounded Product & $500 \mathrm{lbs}$ & $\mathbf{Y}$ & N/A & N/A & $\mathbf{Y}$ \\
\hline Hydrosep & & Encon Saftey Products & Per 609 RM109 & Compounded Product & $40 \mathrm{pts}$ & $\mathrm{Y}$ & N/A & N/A & $\mathbf{Y}$ \\
\hline Ice Melter & & Brody Chem. & Per 609 CCS & Compounded Product & Various & $\mathrm{Y}$ & N/A & N/A & \\
\hline Ingotcote K (Ceramcote) & & Ashland Chemical Ine. & Per 609 RMBI02 & Compounded Product & $35 \mathrm{gal}$ & $\mathbf{Y}$ & N/A & N/A & $\mathbf{Y}$ \\
\hline Jade Set Super & Refactory Mortar & $\begin{array}{l}\text { A.P.Green Refactories } \\
\text { Co. }\end{array}$ & Per 609 RMB102 & Compounded Product & $10 \mathrm{gal}$ & $\mathbf{Y}$ & N/A & N/A & $\mathbf{Y}$ \\
\hline $\begin{array}{l}\text { Joint Compound (ready } \\
\text { mixed) }\end{array}$ & & U.S.Gypsum Co. & $\begin{array}{l}\text { Per } 609 \text { NFPS } \\
\text { RMB107 }\end{array}$ & Compounded Product & 4 gal & $\mathbf{Y}$ & N/A & N/A & $\mathrm{N}$ \\
\hline k-Lens-M & & The Wilkens Co. & Per 609 RM109 & Compounded Product & $80 \mathrm{oz}$ & $\mathrm{Y}$ & N/A & N/A & $\mathbf{Y}$ \\
\hline K-47 Roebic & & Roebic Inc. & Per 609 RMB102 & Compounded Product & $5 \mathrm{qt}$ & $\mathbf{Y}$ & N/A & N/A & $\mathbf{N}$ \\
\hline
\end{tabular}


Table A-1. (continued).

\begin{tabular}{|c|c|c|c|c|c|c|c|c|c|}
\hline Chemical & Trade Name & Manufacturer & Location ${ }^{\mathrm{a}}$ & Description & $\begin{array}{l}\text { Typical } \\
\text { Quantity }\end{array}$ & $\begin{array}{l}\text { MSDS } \\
\mathrm{Y} / \mathrm{N}\end{array}$ & $\begin{array}{l}\text { Shelf } \\
\text { Life }\end{array}$ & $\begin{array}{l}\text { EXP. } \\
\text { Date }\end{array}$ & $\begin{array}{l}\text { SARA } \\
\text { Y/N }\end{array}$ \\
\hline Klenn Stip Paint Thinner & Minerial Spirits & Klenn Strip & $\begin{array}{l}\text { Per } 609 \text { FSC } \\
\text { RM } 109\end{array}$ & Compounded Product & $1 \mathrm{qt}$ & $\mathrm{Y}$ & N/A & N/A & \\
\hline Krylon Primer 1371 & & Borben & Per 609 RM 109 & Compounded Product & $12 \mathrm{oz}$ & $Y$ & $\mathrm{~N} / \mathrm{A}$ & N/A & $\mathbf{N}$ \\
\hline Lacquer Thinner & & Klean Strip & $\begin{array}{l}\text { Per } 609 \text { FSC } \\
\text { RM109 }\end{array}$ & Compounded Product & 5 gal & $\mathbf{Y}$ & N/A & N/A & \\
\hline Lattner Boiler Compound & & P.M. Lattner Mfg. Co. & Per 609 RMBI02 & Trisodium Phosphate & $1 \mathrm{pt}$ & $\mathrm{Y}$ & N/A & N/A & $\mathbf{Y}$ \\
\hline LEC-36 (6V Battery) & & Exide Electronics & Per 609 RMB102 & Compounded Product & 4 & $\mathrm{Y}$ & N/A & N/A & $\mathrm{N}$ \\
\hline Lightguard Q6 & & Exide Electronics & Per 609 RMB102 & Compounded Product & Various & $Y$ & N/A & N/A & \\
\hline $\begin{array}{l}\text { Lithonia Emergency } \\
\text { Lighting }\end{array}$ & & Lithonia & Per 609 RMBI02 & Compounded Product & Various & $\mathrm{Y}$ & N/A & N/A & \\
\hline Lysol Institutional (Aerosol) & & National Laboratories & $\begin{array}{l}\text { Per } 609 \text { CS } \\
\text { RM } 116\end{array}$ & Compounded Product & $252 \mathrm{oz}$ & $Y$ & N/A & $\mathrm{N} / \mathrm{A}$ & $\mathrm{Y}$ \\
\hline Master Bond Part B & & Master Bond Inc. & Per 609 RM 109 & Compounded Product & $1 \mathrm{gal}$ & $\mathrm{Y}$ & N/A & N/A & \\
\hline Master Bond Part A & & Master Bond Inc. & $\begin{array}{l}\text { Per } 609 \text { FSC } \\
\text { RM } 109\end{array}$ & Compounded Product & $1 \mathrm{gal}$ & $Y$ & N/A & N/A & \\
\hline Mercontainer & & EPS Chemical & CC-38 & Compounded Product & $150 \mathrm{lbs}$ & $\gamma$ & N/A & N/A & $Y$ \\
\hline Mg Absorb & & Lab Safety & CC-38 \& Per 623 & Compounded Product & $100 \mathrm{lbs}$ & $\mathbf{Y}$ & N/A & $\mathrm{N} / \mathrm{A}$ & $\mathrm{Y}$ \\
\hline Moldcote 2 & & Huron Industries & $\begin{array}{l}\text { Per } 609 \text { FSC } \\
\text { RM109 }\end{array}$ & Compounded Product & 1 gal & $Y$ & N/A & $\mathrm{N} / \mathrm{A}$ & $Y$ \\
\hline Muriatic Acid & & $\begin{array}{l}\text { Reagent Chemical \& } \\
\text { Research Co. }\end{array}$ & Per 609 RMB 102 & $\begin{array}{l}31.5-36 \% \\
\text { Hydrochloric Acid }\end{array}$ & $1 \mathrm{gal}$ & $\mathrm{Y}$ & N/A & $\mathrm{N} / \mathrm{A}$ & $\mathrm{N}$ \\
\hline NCP-2 & & Norco Co. & Per 609 RMB102 & Compounded Product & $1 \mathrm{pt}$ & $\mathrm{Y}$ & N/A & N/A & \\
\hline NL Gear Compound 220 & & Chevron & Per 609 RMB102 & Compounded Product & 5 gal & $\mathbf{Y}$ & N/A & $\mathrm{N} / \mathrm{A}$ & $\mathbf{Y}$ \\
\hline No.T-36 Refactory Cement & Refactory Mortar & $\begin{array}{l}\text { A.P.Green Industries } \\
\text { Inc. }\end{array}$ & Per 609 RMB102 & Compounded Product & 5 gal & $\mathbf{Y}$ & N/A & N/A & $\mathbf{Y}$ \\
\hline Noalox Joint Compound & & Noalox & Per 609 RM109 & Compounded Product & $8 \mathrm{oz}$ & $\mathbf{Y}$ & N/A & $\mathrm{N} / \mathrm{A}$ & \\
\hline Over \& Under & & Johnson Wax & Per 609 CCS & Compounded Product & $10 \mathrm{gal}$ & $\mathbf{Y}$ & N/A & N/A & \\
\hline
\end{tabular}


Table A-1. (continued).

\begin{tabular}{|c|c|c|c|c|c|c|c|c|c|}
\hline Chemical & Trade Name & Manufacturer & Location $^{a}$ & Description & $\begin{array}{l}\text { Typical } \\
\text { Quantity }\end{array}$ & $\begin{array}{l}\text { MSDS } \\
\mathrm{Y} / \mathrm{N}\end{array}$ & $\begin{array}{l}\text { Shelf } \\
\text { Life }\end{array}$ & $\begin{array}{l}\text { EXP. } \\
\text { Date }\end{array}$ & $\begin{array}{l}\text { SARA } \\
\mathrm{Y} / \mathrm{N}\end{array}$ \\
\hline $\begin{array}{l}\text { P-10 (nuclear counter } \\
\text { Mixture) }\end{array}$ & & Various & Various & Compounded Product & $16200 \mathrm{lbs}$ & $\mathbf{Y}$ & N/A & N/A & $\mathbf{Y}$ \\
\hline Paulmolive Gold Hand Soap & & ColgatePaulmolive Co. & $\begin{array}{l}\text { Per } 609 \text { CS } \\
\text { RM116 }\end{array}$ & Compounded Product & $95 \mathrm{oz}$ & $\mathbf{Y}$ & N/A & N/A & $\mathbf{N}$ \\
\hline PL-400 & Subfloor Adesive & Contect & $\begin{array}{l}\text { Per } 609 \text { FSC } \\
\text { RM109 }\end{array}$ & Compounded Product & $670 \mathrm{oz}$ & $\mathbf{Y}$ & N/A & N/A & \\
\hline Polarvis Multi Hydraulic Oil & & Alantic Richfield & Per 609 RMB102 & Compounded Product & 5 gal & $\mathbf{Y}$ & N/A & N/A & $\mathbf{N}$ \\
\hline Polyurea EP Grease 1 & & Chevron & Per 609 RMB 102 & Compounded Product & 5 gal & $\mathbf{Y}$ & N/A & N/A & $\mathbf{Y}$ \\
\hline Propane & & Various & Per 609 RM109 & Aliphatic Hydrocarbon & $70 \mathrm{oz}$ & $\mathbf{Y}$ & N/A & N/A & $\mathrm{N}$ \\
\hline Propane & & Various & North Pad & Aliphatic Hydrocarbon & $500 \mathrm{gal}$ & $\mathrm{Y}$ & N/A & N/A & $\mathrm{N}$ \\
\hline Propane & & Various & $\begin{array}{l}\text { South wall of Per } \\
609 \text { (exterior) }\end{array}$ & Aliphatic Hydrocarbon & $20 \mathrm{gal}$ & $\mathbf{Y}$ & N/A & N/A & $\mathbf{N}$ \\
\hline Propylene Glycol & & Union Carbide & Per 609 RMB102 & Propylene Glycol & $60 \mathrm{gal}$ & $\mathrm{Y}$ & N/A & $\mathrm{N} / \mathrm{A}$ & $\mathbf{Y}$ \\
\hline PSQ Cleaner & & Spartan & Per 609 RM104 & Compounded Product & $1 \mathrm{gal}$ & $\mathbf{Y}$ & N/A & $\mathbf{N} / \mathbf{A}$ & \\
\hline Quick View Cleaner & & Johnson Wax & Per 609 CCS & Compounded Product & 5 gal & $\mathrm{Y}$ & $\mathrm{N} / \mathrm{A}$ & N/A & \\
\hline Quitolubric 822-220 & & Quaker State & Per 609 RMB102 & Compounded Product & $55 \mathrm{gal}$ & $\mathrm{Y}$ & $\mathrm{N} / \mathrm{A}$ & N/A & $\mathbf{Y}$ \\
\hline Ramik Green & Rodenticide & Haco Inc. & Various & Compounded Product & $4 \mathrm{lbs}$ & $\mathbf{Y}$ & $\mathrm{N} / \mathrm{A}$ & N/A & $\mathrm{N}$ \\
\hline Real Cool Snoop & Snoop & Nupro Co. & $\begin{array}{l}\text { Per } 609 \text { RM113 } \\
\text { \& RMB103 }\end{array}$ & Compounded Product & $8 \mathrm{oz}$ & $\mathbf{Y}$ & N/A & N/A & $\mathrm{N}$ \\
\hline $\begin{array}{l}\text { Rechargeable Battery \# } \\
\text { ELB0604 (6v) }\end{array}$ & & Lithonia Lighting & Per 609 RMB102 & Compounded Product & 1 & $\mathrm{Y}$ & N/A & N/A & $\mathbf{Y}$ \\
\hline Rectorseek & & Rectorseal Corp. & Per 609 RMB102 & Compounded Product & $12 \mathrm{oz}$ & $\mathbf{Y}$ & N/A & N/A & \\
\hline Regal Oil R \& O 100 & & Texaco & Per 609 RMB102 & Compounded Product & $5 \mathrm{gal}$ & $\mathbf{Y}$ & N/A & N/A & \\
\hline Renuzit air freshener & & Drackett Products Co. & Per 609 CCS & Compounded Product & $120 \mathrm{oz}$ & $\mathbf{Y}$ & N/A & N/A & $\mathbf{N}$ \\
\hline $\begin{array}{l}\text { Rugbee Heavy Duty Spot \& } \\
\text { Stain Remover }\end{array}$ & & S.C.Johnson Wax & $\begin{array}{l}\text { Per } 609 \text { FSC } \\
\text { RM109 }\end{array}$ & Compounded Product & 1 gal & $\mathbf{Y}$ & N/A & N/A & $\mathbf{Y}$ \\
\hline $\begin{array}{l}\text { RustOleum Traffic Paint } \\
\text { (aerosol) }\end{array}$ & & RustOleum Corp. & $\begin{array}{l}\text { Per } 609 \text { FSC } \\
\text { RM109 }\end{array}$ & Compounded Product & $320 \mathrm{oz}$ & $\mathrm{Y}$ & Syrs. & $5 / 98$ & \\
\hline
\end{tabular}




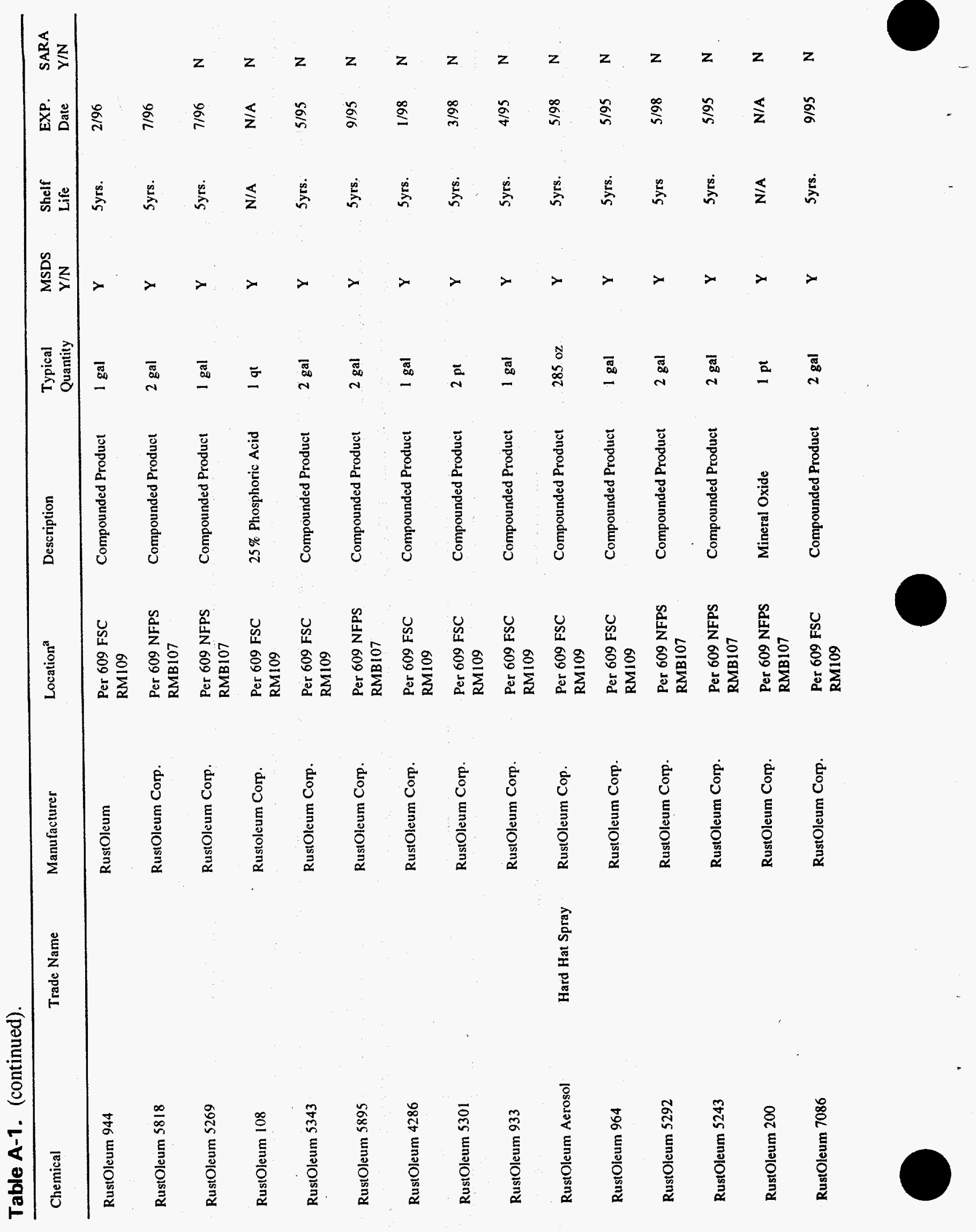


Table A-1. (continued).

\begin{tabular}{|c|c|c|c|c|c|c|c|c|c|}
\hline Chemical & Trade Name & Manufacturer & Location ${ }^{2}$ & Description & $\begin{array}{l}\text { Typical } \\
\text { Quantity }\end{array}$ & $\begin{array}{l}\text { MSDS } \\
\mathrm{Y} / \mathrm{N} \\
\end{array}$ & $\begin{array}{l}\text { Shelf } \\
\text { Life }\end{array}$ & $\begin{array}{l}\text { EXP. } \\
\text { Date }\end{array}$ & $\begin{array}{l}\text { SARA } \\
\mathrm{Y} / \mathrm{N} \\
\end{array}$ \\
\hline $\begin{array}{l}\text { RustOleum } 5800 \text { (Tinting } \\
\text { Colorants) }\end{array}$ & & RustOleum Corp. & $\begin{array}{l}\text { Per } 609 \text { NFPS } \\
\text { RMB107 }\end{array}$ & Compounded Product & $96 \mathrm{oz}$ & $\mathbf{Y}$ & $5 y r s$ & $4 / 97$ & $\mathrm{~N}$ \\
\hline RustOleum 925 & & RustOleum Corp. & $\begin{array}{l}\text { Per } 609 \text { FSC } \\
\text { RM109 }\end{array}$ & Compounded Product & $1 \mathrm{gal}$ & $\mathbf{Y}$ & $5 y r s$ & $5 / 95$ & $\mathbf{N}$ \\
\hline RustOleum 5222 & & RustOleum Corp. & $\begin{array}{l}\text { Per } 609 \text { NFPS } \\
\text { RMB107 }\end{array}$ & Compounded Product & $2 \mathrm{gal}$ & $\mathbf{Y}$ & $5 y r s$ & $2 / 95$ & $\mathbf{N}$ \\
\hline RX-14 Refactory Coating & & R.X.Chemical Co. Inc. & Per 609 RMB102 & Compounded Product & 2 gal & $\mathbf{Y}$ & $\mathrm{N} / \mathrm{A}$ & $\mathrm{N} / \mathrm{A}$ & $\mathbf{Y}$ \\
\hline RX-36 Refactory Coating & & R.X. Chemical Co. Inc. & Per 609 RMB102 & Compounded Product & $2 \mathrm{gal}$ & $\mathbf{Y}$ & N/A & N/A & $\mathbf{Y}$ \\
\hline Shred Pax & & Fiske Brothers Co. & Per 609 RMB102 & Compounded Product & $15 \mathrm{gal}$ & $\mathbf{Y}$ & N/A & N/A & \\
\hline Silicate Catalyst & & $\begin{array}{l}\text { Delta Resin \& } \\
\text { Refactories }\end{array}$ & Per 609 RMB 102 & Compounded Product & $20 \mathrm{gal}$ & $\mathbf{Y}$ & N/A & N/A & $\mathrm{Y}$ \\
\hline Silicone Spray Lubricant & & $\begin{array}{l}\text { Radiator Specialty Co. } \\
\text { (aerosol) }\end{array}$ & $\begin{array}{l}\text { Per } 609 \text { FSC } \\
\text { RM109 }\end{array}$ & Compounded Product & $14 \mathrm{oz}$ & $\mathbf{Y}$ & N/A & N/A & \\
\hline Sodium Bicarbonate & BC extinguisher & Various & Various & Sodium Bicardonate & Various & $\mathbf{Y}$ & N/A & $\mathrm{N} / \mathrm{A}$ & $\mathbf{N}$ \\
\hline SOS Soap Pads & & Miles Inc. & Per 609 CCs & Compounded Product & 234 pads & $\mathbf{Y}$ & N/A & N/A & \\
\hline Sparkling & & Spartan Chemical Co. & $\begin{array}{l}\text { Per } 609 \text { CS } \\
\text { RM116 \& } \\
\text { RM104 }\end{array}$ & $\begin{array}{l}9.5 \% \text { Hydrochloric } \\
\text { Acid }\end{array}$ & $1 \mathrm{qt}$ & $\mathbf{Y}$ & N/A & N/A & $\mathbf{Y}$ \\
\hline Spic \& Span & & Proctor \& Gamble & Per 609 RM116 & Compounded Product & 75 & $\mathbf{Y}$ & N/A & N/A & \\
\hline $\begin{array}{l}\text { Spray Buff Cleaner \& } \\
\text { Polish }\end{array}$ & & 3M Center & Per 609 RM1 16 & Compounded Product & $1 \mathrm{gal}$ & $\mathbf{Y}$ & N/A & N/A & $\mathbf{Y}$ \\
\hline SSR Ultra Coolant & & Ingersoll Rand & Per 609 RMB102 & Compounded Product & $1 \mathrm{gal}$ & $\mathbf{Y}$ & N/A & N/A & $\mathbf{Y}$ \\
\hline Stainless Steel polish & & 3M Center & Per 609 RM116 & Compounded Product & $21 \mathrm{oz}$ & $\mathbf{Y}$ & N/A & N/A & $\mathbf{Y}$ \\
\hline Super Freeze Mist (aerosol) & & GC Electronics & Per 609 RM102 & $\begin{array}{l}\text { 100\% Dichloro- } \\
\text { difluoromethane }\end{array}$ & $15 \mathrm{oz}$ & $\mathbf{Y}$ & N/A & N/A & $\mathrm{N}$ \\
\hline Tapmatic & & Triple E & Per 609 RM109 & Compounded Product & $5 \mathrm{oz}$ & $\mathbf{Y}$ & N/A & N/A & \\
\hline $\begin{array}{l}\text { Thermal Arc Tourch } \\
\text { Coolant }\end{array}$ & & Thermal Dynamics & Per 622 & Compounded Product & $1 \mathrm{gal}$ & $\mathbf{Y}$ & N/A & N/A & $\mathbf{Y}$ \\
\hline
\end{tabular}


Table A-1. (continued).

\begin{tabular}{|c|c|c|c|c|c|c|c|c|c|}
\hline Chemical & Trade Name & Manufacturer & Location $^{\mathbf{a}}$ & Description & $\begin{array}{l}\text { Typical } \\
\text { Quantity }\end{array}$ & $\begin{array}{l}\text { MSDS } \\
\text { Y/N }\end{array}$ & $\begin{array}{l}\text { Shelf } \\
\text { Life }\end{array}$ & $\begin{array}{l}\text { EXP. } \\
\text { Date }\end{array}$ & $\begin{array}{l}\text { SARA } \\
\text { Y/N }\end{array}$ \\
\hline Thermalcote & & Themalloy Inc. & Per 609 RMBI02 & Compounded Product & $2 \mathrm{oz}$ & $\mathrm{Y}$ & N/A & N/A & $\mathrm{Y}$ \\
\hline Traffic Paint (aerosol) & & Fox Valley & $\begin{array}{l}\text { Per } 609 \text { FSC } \\
\text { RM109 }\end{array}$ & Compounded Product & $234 \mathrm{oz}$ & $Y$ & & & \\
\hline Tuff Bond & Adhesive & Goodloe E Moore Inc. & $\begin{array}{l}\text { Per } 609 \text { FSC } \\
\text { RM109 }\end{array}$ & Compounded Product & $1 \mathrm{gal}$ & $Y$ & $N / A$ & N/A & \\
\hline Ultragel 2 & & Johnson \& Johnson & Per 609 RMBI02 & Compounded Product & $72 \mathrm{oz}$ & $\mathrm{Y}$ & N/A & N/A & \\
\hline Unocal Unoba EP Grease 2 & $\ldots$ & Unocal Oil Co. & $\begin{array}{l}\text { Per } 609 \text { RM } 109 \\
\& \text { RMB } 103\end{array}$ & Compounded Product & $\begin{array}{l}28 \mathrm{oz} \\
\text { RM109 } \\
280 \mathrm{oz} \\
\text { RMB103 }\end{array}$ & $\mathrm{Y}$ & N/A & N/A & $\mathbf{N}$ \\
\hline Urinal Blocks & & Triple $S$ & Per 609 RM116 & Compounded Product & $44 \mathrm{oz}$ & $\mathrm{Y}$ & N/A & N/A & \\
\hline Vinyl Spackling & & Crawford Products Co. & Per 609 RMBI07 & Compounded Product & $4 \mathrm{qt}$ & $\mathrm{Y}$ & N/A & N/A & $\mathrm{N}$ \\
\hline WD-40 & & WD-40 Co. & Per 609 RM 109 & Compounded Product & $4 \mathrm{qt}$ & $\mathrm{Y}$ & N/A & N/A & $N$ \\
\hline Windex & & Drackett Products Co. & Per 609 RM 116 & Compounded Product & $4 \mathrm{qt}$ & $\mathrm{Y}$ & N/A & $\mathrm{N} / \mathrm{A}$ & $\mathbf{N}$ \\
\hline \multicolumn{10}{|c|}{$\begin{array}{l}\text { a. The abbreviations for the locations include } \\
\text { FSC - Flammable Storage Cabinet } \\
\text { CS - Custodial Storage } \\
\text { NFPS - Nonflammable Paint Storage } \\
\text { CCS - Cargo Container Storage }\end{array}$} \\
\hline
\end{tabular}




\section{Appendix B}

Facility Limits for Hazardous Materials without a TPO or RQ 
-
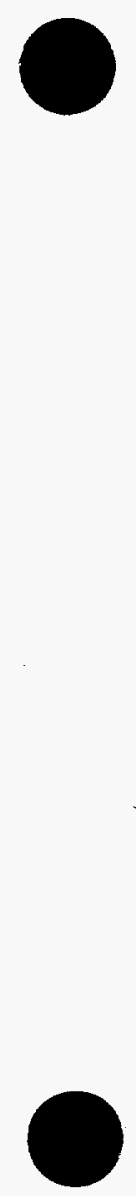


\section{Appendix B}

\section{Facility Limits for Hazardous Materials without a TPQ or RO}

The nonradiological hazardous materials have been identified for WERF. Most of the hazardous materials identified had a TPQ or RQ value which was used to determine the facility limit quantity. This appendix provides the calculations that were used to obtain the facility limit quantity for those hazardous materials that did not have a TPQ or RQ value. The facility limit for these hazardous materials are based on air concentration limits or other properties associated with the particular hazardous material.

\section{B-1. FACILITY LIMITS SET USING AIR CONCENTRATION LIMITS}

For chemicals with neither a TPQ nor RQ, emergency air concentration limits (e.g., IDLH) or workplace air concentration limits (e.g., TLV-TWA or TLV-STEL) were used to establish a facility limit quantity. The limiting quantities are established by not exceeding the specified air concentration limit at $100 \mathrm{~m}$ (minimum distance because of calculation limitations of dispersion codes) for the worse case accident. The worse case accident is a facility fire where the chemicals are consumed and released over 8 hours. The RSAC- 4 computer $\operatorname{code}^{1}$ has been used to model the atmospheric dispersion coefficients for the worst case meteorological conditions and to determine the air concentrations at the receptor location $(100 \mathrm{~m})$ during accident conditions for a ground release. A ground release is considered to be bounding because the plume from a release above the ground (i.e., stack release) may touch down well past the nearest site boundary. Plume concentrations at the time of touch down for a stack release are less than the plume concentrations for a ground release. The meteorological parameters ${ }^{2}$ used in the RSAC-4 calculations for the worse case release include

- Weather Class

- Wind Speed (less than $2 \mathrm{~km}$ )

- Wind Speed (greater than $2 \mathrm{~km}$ )

- Air Density

- Sigma Y

- Sigma Z
F

$0.5 \mathrm{~m} / \mathrm{s}$

$2.0 \mathrm{~m} / \mathrm{s}$

$1.099 \mathrm{E}+03 \mathrm{~g} / \mathrm{m}^{3}$

Markee

Markee.

The X/Q (dispersion coefficient related to the expansion of the vapor cloud in units of seconds per cubic meter) value ${ }^{3}$ at $100 \mathrm{~m}$ is listed in Table B-1. The quantity released to cause the airborne concentration limit (in $\mathrm{kg}$ ) are calculated by dividing the $\mathrm{X} / \mathrm{Q}$ value $\left(\mathrm{s} / \mathrm{m}^{3}\right)$ into the concentration limit (may be either $0.1 *$ IDLH, 1/8*TLV-STEL, or TLV-TWA in $\mathrm{mg} / \mathrm{m}^{3}$ ) and dividing the result by $1.0 \mathrm{E}+06$ to convert from $\mathrm{mg}$ to $\mathrm{kg}$. Table B-1 displays the results of the calculations. Since the calculated number is the total quantity released to reach the airborne limit, it is similar to the RQ value. Therefore, this quantity is divided by the release fraction to get the facility quantity limits. The maximum quantity is limited to $4,540 \mathrm{~kg}(10,000 \mathrm{lb})$.

\section{B-2. FACILITY LIMITS SET USING OTHER MATERIAL PROPERTIES}

Some hazardous materials do not have an established TPQ, RQ, or air concentration limits. For these hazardous materials other methods were used to determine a facility limit quantity. Gold is not considered poisonous and is relatively inert. Therefore, in accordance with 40 CFR 355 , the facility limit for gold can be set at 4,540 $\mathrm{kg}(10,000 \mathrm{lb})$. Gold Cyanide emits $\mathrm{CN}^{-}$ion when heated and 
therefore the limit is established the same as the RQ for Cyanides $(4.536 \mathrm{~kg})$, which produces a facility limit of $4536 \mathrm{~kg}(10,000 \mathrm{lb})$. For magnesium, the quantity is based on the TLV-TWA for magnesium oxide since this is the likely form of release due to its reactivity. The quantity for potassium is determined in the same manner as magnesium using the TLV-STEL for potassium hydroxide. The ester limit is determined by using the TLV-TWA for emery (CAS No. 12415-34-8). Strontium is similar to calcium; therefore, the limiting quantities for calcium may be used for strontium. Thorium is assumed to be thorium-232 which is an alpha emitter. The limit for "any other alpha emitter" is 2 curies. ${ }^{4}$ The 2 curies translates into $18,500 \mathrm{~kg}$ of thorium; therefore the facility limit is set at $4,540 \mathrm{~kg}(10,000 \mathrm{lb})$.

For boron, a dose of $6 \mathrm{~g}$ to an infant can be fatal. Therefore, $6 \mathrm{~g}$ is used as the facility limiting quantity. Doses obtained through inhalation do not correspond to doses obtained through ingestion. Ingested doses go through the stomach and are absorbed through the intestines. Inhaled doses are absorbed through the lungs. An inhaled dose may not represent the actual dose absorbed by the body since a fraction of the material may be exhaled rather than absorbed. Therefore, using an inhaled dose adds another layer of conservatism to the calculation.

Since the worse case event scenario is fire lasting for at least 8 hours, the airborne concentration that a person would have to breathe for 8 hours in order to inhale $6 \mathrm{~g}$ is calculated. A formula for this calculation is found in the EPA "Exposure Factors Handbook"5 and is as follows:

$$
\mathrm{IHX}=\mathrm{IR} \times \mathrm{ED} \times \mathrm{C}
$$

where

$$
\begin{aligned}
& \text { IHX = Inhalation exposure }(\mathrm{mg})-6,000 \mathrm{mg}(6 \mathrm{~g}) \\
& \mathrm{IR}=\text { Inhalation rate }\left(\mathrm{m}^{3} / \mathrm{h}\right)-4.2 \mathrm{~m}^{3} / \mathrm{h} \text { for an adult at a high activity level } \\
& \mathrm{ED}=\text { duration of exposure event (hours) }-8 \text { hours } \\
& \mathrm{C}=\text { average air concentration for boron }
\end{aligned}
$$

Thus, substituting into the above equation,

$$
6,000 \mathrm{mg}=4.2 \mathrm{~m}^{3} / \mathrm{h} \times 8 \mathrm{~h} \times \mathrm{C}
$$

and solving for $\mathrm{C}$,

$$
\mathrm{C}=178.6 \mathrm{mg} / \mathrm{m}^{3}
$$

The calculated average concentration is fatal for an accident lasting 8 hours. This value is reduced by a factor of ten for conservatism and used as an air concentration limit to calculate the facility quantity limit for this chemical.

\section{B-3. REFERENCES}

1. D. R. Wenzel, "Radiological Safety Analysis Code (RSAC-4)," Version 4.03, April 10,1990.

2. G. E. Stuart, NOAA, to L. Finch, WINCO, "Interim Guidance for Dispersion Calculations at ICPP," March 1989.

3. WERF-0232, "Accident Analysis of Anticipated Accidents." 
4. 10 CFR 30.72, "Schedule C-Quantities of radioactive materials requiring consideration of the need for an emergency plan for responding to a release," Code of Federal Regulations Chapter 10, Part 30.72, January 1991.

5. U. S. Environmental Protection Agency, Exposure Factors Handbook, PB90-106774, July 1989. 

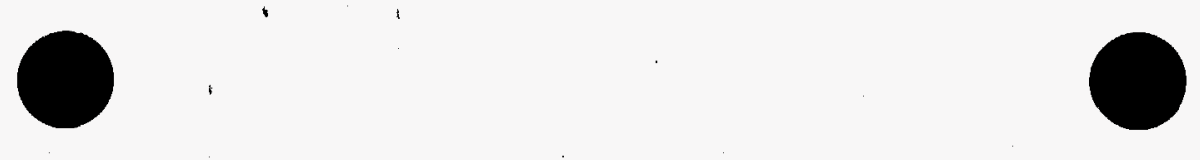

Table B-1. Calculation of release quantities from air concentration limits.

\begin{tabular}{|c|c|c|c|c|c|c|c|}
\hline Material & $\begin{array}{l}\text { Calculated Release } \\
\text { Quantity } \\
(\mathrm{kg})\end{array}$ & $\begin{array}{l}\text { Duration } \\
\text { (s) }\end{array}$ & $\begin{array}{l}X / Q \\
\left(s / m^{3}\right)\end{array}$ & $\begin{array}{c}\text { Windspeed } \\
(\mathrm{m} / \mathrm{s})\end{array}$ & $\begin{array}{l}\text { Distance } \\
\text { (m) }\end{array}$ & $\begin{array}{c}\text { Air } \\
\text { Concentration } \\
\text { Limit } \\
\left(\mathrm{mg} / \mathrm{m}^{3}\right)\end{array}$ & Type of limit ${ }^{2}$ \\
\hline Barium & 1.694 & 28800 & $8.50 \mathrm{E}-03$ & 0.5 & 100 & 0.5 & TLV-TWA \\
\hline Bismuth & 0.2118 & 28800 & $8.50 \mathrm{E}-03$ & 0.5 & 100 & 0.0625 & $\begin{array}{l}\text { STEL of } 0.5 \mathrm{mg} / \mathrm{m}^{3} \text { divided by } 8 \text { to estimate } \\
\text { TLV-TWA }\end{array}$ \\
\hline Boron & 60.51 & 28800 & $8.50 \mathrm{E}-03$ & 0.5 & 100 & 17.86 & $\begin{array}{l}\text { Estimated from lethal conc of } 6 \mathrm{~g} \text { to child } \\
\text { (reduced by factor of } 10 \text { ) }\end{array}$ \\
\hline Butoxy Ethanol-2 & 112.8 & 28800 & $8.50 \mathrm{E}-03$ & 0.5 & 100 & 33.3 & $1 / 10$ IDLH $\left(700 \mathrm{ppm}\right.$ or $\left.3328 \mathrm{mg} / \mathrm{m}^{3}\right)$ \\
\hline Calcium & 0.6776 & 28800 & $8.50 \mathrm{E}-03$ & 0.5 & 100 & 0.2 & TLV-TWA \\
\hline Cobalt & 0.1694 & 28800 & $8.50 \mathrm{E}-03$ & 0.5 & 100 & 0.05 & TLV-TWA \\
\hline Ester & 16.94 & 28800 & $8.50 \mathrm{E}-03$ & 0.5 & 100 & 5 & TLV-TWA for EMERY as representative \\
\hline Ethyl Alcohol & 6438.0 & 28800 & $8.50 \mathrm{E}-03$ & 0.5 & 100 & 1900 & TLV-TWA \\
\hline Freon-113 & 25751.0 & 28800 & $8.50 \mathrm{E}-03$ & 0.5 & 100 & 7600 & TLV-TWA \\
\hline Hexane & 6099.0 & 28800 & $8.50 \mathrm{E}-03$ & 0.5 & 100 & 1800 & $1 / 10$ IDLH ( $5000 \mathrm{ppm}$ or $18000 \mathrm{mg} / \mathrm{mm}^{3}$ ) \\
\hline Iron & 33.88 & 28800 & $8.50 \mathrm{E}-03$ & 0.5 & 100 & 10 & TLV-TWA \\
\hline Magnesium & 33.88 & 28800 & $8.50 \mathrm{E}-03$ & 0.5 & 100 & 10 & TLV-TWA for Magnesium Oxide \\
\hline Manganese & 3.388 & 28800 & $8.50 \mathrm{E}-03$ & 0.5 & 100 & 1. & TLV-TWA \\
\hline Methylnaphthalene-2 & 8.471 & 28800 & $8.50 \mathrm{E}-03$ & 0.5 & 100 & 2.5 & $\begin{array}{l}\text { STEL of } 20 \mathrm{mg} / \mathrm{m}^{3} \text { divided by } 8 \text { to estimate } \\
\text { TLV-TWA }\end{array}$ \\
\hline Mineral Oil & 16.94 & 28800 & $8.50 \mathrm{E}-03$ & 0.5 & 100 & 5 & TLV-TWA \\
\hline Molybdenum & 16.94 & 28800 & $8.50 \mathrm{E}-03$ & 0.5 & 100 & 5 & TLV-TWA \\
\hline Oxalic Acid & 169.4 & 28800 & $8.50 \mathrm{E}-03$ & 0.5 & 100 & 50 & $1 / 10$ IDLH $\left(500 \mathrm{mg} / \mathrm{m}^{3}\right)$ \\
\hline Perchlorates & 0.3388 & 28800 & $8.50 \mathrm{E}-03$ & 0.5 & 100 & 0.1 & TLV-TWA \\
\hline Petroleum Naphtha & 13553.0 & 28800 & $8.50 \mathrm{E}-03$ & 0.5 & 100 & 4000 & $1 / 10$ IDLH $\left(10000 \mathrm{ppm}\right.$ or $\left.40000 \mathrm{mg} / \mathrm{m}^{3}\right)$ \\
\hline Polytetrafluoroethylene & 4.235 & 28800 & $8.50 \mathrm{E}-03$ & 0.5 & 100 & 1.25 & $\begin{array}{l}\text { STEL of } 10 \mathrm{mg} / \mathrm{m}^{3} \text { (from USSR) divided by } 8 \text { to } \\
\text { estimate TLV-TWA }\end{array}$ \\
\hline
\end{tabular}


Table B-1. (continued).

\begin{tabular}{|c|c|c|c|c|c|c|c|}
\hline Material & $\begin{array}{l}\text { Calculated Release } \\
\text { Quantity } \\
\text { (kg) }\end{array}$ & $\begin{array}{l}\text { Duration } \\
\text { (s) }\end{array}$ & $\begin{array}{c}X / Q \\
\left(s / m^{3}\right)\end{array}$ & $\begin{array}{l}\text { Windspeed } \\
(\mathrm{m} / \mathrm{s})\end{array}$ & $\begin{array}{l}\text { Distance } \\
\text { (m) }\end{array}$ & $\begin{array}{c}\text { Air } \\
\text { Concentration } \\
\text { Limit } \\
\left(\mathrm{mg} / \mathrm{m}^{3}\right)\end{array}$ & Type of limit \\
\hline Potassium & 0.2118 & 28800 & $8.50 \mathrm{E}-03$ & 0.5 & 100 & 0.0625 & $\begin{array}{l}\text { TLV-C of } 2 \mathrm{mg} / \mathrm{m}^{3} \text { for potassium hydroxide } \\
\text { divided by } 4 \text { to determine ceiling and divided by } \\
8 \text { to estimate TLV-TWA }\end{array}$ \\
\hline Sodium Chloride & 2.118 & 28800 & $8.50 \mathrm{E}-03$ & 0.5 & 100 & 0.625 & $\begin{array}{l}\text { STEL of } 5 \mathrm{mg} / \mathrm{m}^{3} \text { (from USSR) divided by } 8 \text { to } \\
\text { estimate TLV-TWA }\end{array}$ \\
\hline Sodium Sulfate & 4.235 & 28800 & $8.50 \mathrm{E}-03$ & 0.5 & 100 & 1.25 & $\begin{array}{l}\text { STEL of } 10 \mathrm{mg} / \mathrm{m}^{3} \text { (from USSR) divided by } 8 \text { to } \\
\text { estimate TLV-TWA }\end{array}$ \\
\hline Strontium & 0.6776 & 28800 & $8.50 \mathrm{E}-03$ & 0.5 & 100 & 0.2 & $\begin{array}{l}\text { TLV-TWA for calcium used, strontium is } \\
\text { similar }\end{array}$ \\
\hline Sulfide & 0.0847 & 28800 & $8.50 \mathrm{E}-03$ & 0.5 & 100 & 0.025 & $\begin{array}{l}\text { STEL of } 0.2 \mathrm{mg} / \mathrm{m}^{3} \text { (from USSR) divided by } 8 \\
\text { to estimate TLV-TWA }\end{array}$ \\
\hline Thorium & 18500.0 & 28800 & $8.50 \mathrm{E}-03$ & 0.5 & 100 & 5460.1 & $\begin{array}{l}\text { Estimated from the maximum grams of thorium } \\
\text { for } 2 \text { curies as indicated for alpha emitters in } 10 \\
\text { CFR } 30\end{array}$ \\
\hline Tin & 135.53 & 28800 & $8.50 \mathrm{E}-03$ & 0.5 & 100 & 40 & $1 / 10$ IDLH $\left(400 \mathrm{mg} / \mathrm{m}^{3}\right)$ \\
\hline Tributyl Phosphate & 461.1 & 28800 & $8.50 \mathrm{E}-03$ & 0.5 & 100 & 136.1 & $1 / 10$ IDLH $\left(125 \mathrm{ppm}\right.$ or $\left.1361 \mathrm{mg} / \mathrm{m}^{3}\right)$ \\
\hline Trichlorobenzene-1,2,3 & 15.67 & 28800 & $8.50 \mathrm{E}-03$ & 0.5 & 100 & 4.625 & $\begin{array}{l}\text { STEL of } 37 \mathrm{mg} / \mathrm{m}^{3} \text { divided by } 8 \text { to estimate } \\
\text { TLV-TWA }\end{array}$ \\
\hline Trimethylbenzene-1,2,4 & 406.6 & 28800 & $8.50 \mathrm{E}-03$ & 0.5 & 100 & 120 & TLV-TWA (from Japan) \\
\hline Vanadium & 1.694 & 28800 & $8.50 E-03$ & 0.5 & 100 & 0.5 & TLV-TWA (from United Kingdom) \\
\hline
\end{tabular}
from the American Conference of Governmental Industrial Hygienists, "Threshold Limit Values and Biological Exposure Indices," 1992 (unless a foreign origin is indicated). TLV-TWA, TLV-STEL, and TLV-C values with a foreign origin come from "Occupational Exposure Limits for Airborne Toxic Substances" by the International Labour Organisation, Geneva, 1991. 


\section{Appendix C}

\section{Event Consequence Results}


-

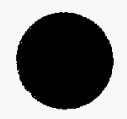

- 


\section{Appendix C}

\section{EVENT CONSEQUENCE RESULTS}

This appendix provides the event consequence results for each hazardous material analyzed in this analysis. A consequence result table is presented for each hazardous material modeled with the ALOHA or EPI dispersion code. The tables indicate the type of release modeled and the peak concentrations estimated at the various receptor locations for the two sets of meteorological conditions. The tables also provide the ERPG or equivalent values used as protective action criteria for each hazardous material evaluated. The tables also indicate the highest emergency class for each release that was modeled. 
Table C-1. Summary of event consequences for a release of acenapthene.

\begin{tabular}{|c|c|c|c|c|c|c|c|c|c|c|}
\hline \multirow[b]{2}{*}{ Release Type } & \multirow[b]{2}{*}{$\begin{array}{l}\text { Meteorological } \\
\text { conditions }\end{array}$} & \multicolumn{3}{|c|}{$\begin{array}{c}\begin{array}{c}\text { Peak concentration (time to) } \\
(\mathrm{ppm})\end{array} \quad \begin{array}{c}(\mathrm{min}) \\
\end{array} \\
\end{array}$} & \multicolumn{2}{|c|}{$\begin{array}{l}\text { Protective action criteria" } \\
\text { (ppm) }\end{array}$} & \multirow{2}{*}{$\begin{array}{c}\text { Highest } \\
\text { emergency } \\
\text { class }\end{array}$} & \multicolumn{3}{|c|}{$\begin{array}{l}\text { Distance to ERPG or equivalent } \\
\qquad(\mathrm{m})\end{array}$} \\
\hline & & $100 \mathrm{~m}$ & $756 \mathrm{~m}$ & $5,200 \mathrm{~m}$ & Alert & $\begin{array}{c}\text { Site Area or General } \\
\text { Emergency }^{c}\end{array}$ & & $\begin{array}{l}\text { ERPG-1 or } \\
\text { equivalent }\end{array}$ & $\begin{array}{l}\text { ERPG-2 or } \\
\text { equivalent }\end{array}$ & $\begin{array}{l}\text { ERPG-3 or } \\
\text { equivalent }\end{array}$ \\
\hline \multirow{3}{*}{ Direct } & $95 \%$ worst-case & $5.34(5)$ & $\mathrm{NSC}^{\mathrm{e}}$ & NSC & 10 & NLA $^{f}$ & - & NSC & NLA & NLA \\
\hline & & & & & & & . & & & \\
\hline & Typical & $1.59(4)$ & NSC & NSC & 10 & NLA & - & NSC & NLA & NLA \\
\hline
\end{tabular}

a. Protective action criteria are based on company guidelines for determining event classification. The definitions for event classifications of hazardous material releases at the INEL are discussed in the text.

b. The Alert protective action criteria value listed is the ERPG-1 equivalent (TLV-STEL) value for acenapthene.

c. There is no Site Area Emergency or General Emergency protective action criteria value listed for acenapthene.

d. The company guidelines for ERPGs and ERPG equivalents are discussed in the text. There is no ERPG-3 or equivalent concentration for acenapthene.

e. NSC stands for No Significant Consequences. The estimated airborne concentrations were not significant at this receptor location or the ERPG (or equivalent) concentration was not exceeded at $100 \mathrm{~m}$. 
Table C-2. Summary of event consequences for a release of acetic acid.

\begin{tabular}{|c|c|c|c|c|c|c|c|c|c|c|}
\hline \multirow[b]{2}{*}{ Release Type } & \multirow[b]{2}{*}{$\begin{array}{l}\text { Meteorological } \\
\text { conditions }\end{array}$} & \multirow[b]{2}{*}{$100 \mathrm{~m}$} & \multicolumn{2}{|c|}{$\begin{array}{l}\text { Peak concentration (time to) } \\
\begin{array}{c}(\mathrm{ppm}) \\
\text { (min) }\end{array}\end{array}$} & \multicolumn{2}{|c|}{$\begin{array}{l}\text { Protective action criterisa } \\
\text { (ppm) }\end{array}$} & \multirow{2}{*}{$\begin{array}{c}\begin{array}{c}\text { Highest } \\
\text { emergency } \\
\text { class }\end{array} \\
\end{array}$} & \multicolumn{3}{|c|}{$\begin{array}{l}\text { Distance to ERPG or equivalent }{ }^{d} \\
(\mathrm{~m})\end{array}$} \\
\hline & & & $756 \mathrm{~m}$ & $5,200 \mathrm{~m}$ & Alert $^{b}$ & $\begin{array}{l}\text { Site Area or General } \\
\text { Emergency }^{\mathrm{c}}\end{array}$ & & $\begin{array}{l}\text { ERPG-1 or } \\
\text { equivalent }\end{array}$ & $\begin{array}{l}\text { ERPG-2 or } \\
\text { equivalent }\end{array}$ & $\begin{array}{l}\text { ERPG-3 or } \\
\text { equivalent }\end{array}$ \\
\hline & $95 \%$ worst-case & $334(5)$ & $13.1(22)$ & NSCe & 30 & 50 & Site Area & 430 & 315 & NSC \\
\hline \multicolumn{11}{|l|}{ Direct } \\
\hline & Typical & $221(5)$ & $4.72(7)$ & NSC & 30 & 50 & Site Area & 285 & 218 & NSC \\
\hline & $95 \%$ worst-case & $15.5(4)$ & $\mathrm{NSC}$ & NSC & 30 & 50 & - & NSC & NSC & NSC \\
\hline \multicolumn{11}{|l|}{ Spill } \\
\hline & Typical & $1.6(3)$ & NSC & NSC & 30 & 50 & - & NSC & NSC & NSC \\
\hline \multirow{3}{*}{ Spill w/ fire } & $95 \%$ worst-case & $529(5)$ & $19.5(23)$ & $\mathrm{NSC}$ & 30 & 50 & Site Area & 562 & 410 & NSC \\
\hline & & & & & & & & & & \\
\hline & Typical & $243(20)$ & $4.79(25)$ & NSC & 30 & 50 & Site Area & 292 & 226 & NSC \\
\hline
\end{tabular}

a. Protective action criteris are based on company guidelines for determining event classification. The definitions for event classifications of hazardous material releases at the INEL are discussed in the text.

b. The Alert protective action criteria value listed is the ERPG-1 equivalent (3*TLV.TWA) value for acetic acid.

c. The Site Area Emergency and General Emergency protective action criteria value listed is the ERPG-2 equivalent (5*TLV-TWA) value for acetic acid.

d. The company guidelines for ERPGs and ERPG equivalents are discussed in the text. The ERPG-3 equivalent (IDLH) concentration of 1,000 ppm for acetic acid was used.

e. NSC stands for No Significant Consequences. The estimated airbome concentration was not significant at this receptor location or the ERPG (or equivalent) concentration was not exceeded at $100 \mathrm{~m}$. 
Table C-3. Summary of event consequences for a release of acetone.

\begin{tabular}{|c|c|c|c|c|c|c|c|c|c|c|}
\hline \multirow[b]{2}{*}{ Release Type } & \multirow[b]{2}{*}{$\begin{array}{l}\text { Meteorological } \\
\text { conditions }\end{array}$} & \multicolumn{3}{|c|}{$\begin{array}{l}\text { Peak concentration (time to) } \\
\begin{array}{c}(\mathrm{ppm}) \\
(\mathrm{min})\end{array}\end{array}$} & \multicolumn{2}{|c|}{$\begin{array}{l}\text { Protective action criteria } \\
\text { (ppm) }\end{array}$} & \multirow{2}{*}{$\begin{array}{c}\begin{array}{c}\text { Highest } \\
\text { emergency } \\
\text { class }\end{array} \\
\end{array}$} & \multicolumn{3}{|c|}{$\begin{array}{l}\text { Distance to ERPG or equivalent } \\
\text { (m) }\end{array}$} \\
\hline & & $100 \mathrm{~m}$ & $756 \mathrm{~m}$ & $5,200 \mathrm{~m}$ & Alert ${ }^{b}$ & $\begin{array}{l}\text { Site Area or General } \\
\text { Emergency }{ }^{\circ}\end{array}$ & & $\begin{array}{l}\text { ERPG-1 or } \\
\text { equivalent }\end{array}$ & $\begin{array}{l}\text { ERPG-2 or } \\
\text { equivalent }\end{array}$ & $\begin{array}{l}\text { ERPG-3 or } \\
\text { equivalent }\end{array}$ \\
\hline & $95 \%$ worst-case & $347(5)$ & $\mathrm{NSC}^{*}$ & NSC & 1,000 & 3,750 & - & NSC & NSC & NSC \\
\hline \multicolumn{11}{|l|}{ Direct } \\
\hline & Typical & $209(5)$ & NSC & NSC & 1,000 & 3.750 & - & NSC & NSC & NSC \\
\hline & $95 \%$ worst-case & $101(5)$ & NSC & $\mathrm{NSC}$ & 1,000 & 3,750 & - & NSC & NSC & NSC \\
\hline \multicolumn{11}{|l|}{ Spill } \\
\hline & Typical & $37.5(3)$ & NSC & NSC & 1,000 & 3,750 & - & NSC & NSC & NSC \\
\hline & $95 \%$ worst-case & $143(5)$ & NSC & NSC & 1,000 & 3,750 & - & NSC & NSC & NSC \\
\hline \multicolumn{11}{|l|}{ Spill w/ fire } \\
\hline & Typical & $13.5(3)$ & $\mathrm{NSC}$ & NSC & 1,000 & 3,750 & : & NSC & NSC & NSC \\
\hline
\end{tabular}

a. Protective action criteria are based on company guidelines for determining event classification. The definitions for event classifications of hazardous material releases at the INEL are discussed in the text.

b. The Alert protective action criteria value listed is the ERPG-1 equivalent (TLV-STEL) value for acetone.

c. The Site Area Emergency and General Emergency protective action criteria value listed is the ERPG-2 equivalent (5*TLV-TWA) value for acetone.

d. The company guidelines for ERPGs and ERPG equivalents are discussed in the text. The ERPG-3 equivalent (IDLH) concentration of 20,000 ppm for acetone was used.

e. NSC stands for No Significant Consequences. The estimated airborne concentration was not significant at this receptor location or the ERPG (or equivalent) concentration was not exceeded at $100 \mathrm{~m}$. 
Table C-4. Summary of event consequences for a release of acetophenone.

\begin{tabular}{|c|c|c|c|c|c|c|c|c|c|c|}
\hline \multirow[b]{2}{*}{ Release Type } & \multirow[b]{2}{*}{$\begin{array}{l}\text { Meteorological } \\
\text { conditions }\end{array}$} & \multicolumn{3}{|c|}{$\begin{array}{l}\text { Peak concentration (time to) } \\
\begin{array}{cc}(\mathrm{ppm}) \quad(\mathrm{min}) \\
\end{array}\end{array}$} & \multicolumn{2}{|c|}{$\begin{array}{c}\text { Protective action criteriaf } \\
\text { (ppm) }\end{array}$} & \multirow{2}{*}{$\begin{array}{c}\text { Highest } \\
\text { emergency } \\
\text { class }\end{array}$} & \multicolumn{3}{|c|}{$\begin{array}{l}\text { Distance to ERPG or equivalent }{ }^{d} \\
(\mathrm{~m})\end{array}$} \\
\hline & & $100 \mathrm{~m}$ & $756 \mathrm{~m}$ & $5,200 \mathrm{~m}$ & Alert ${ }^{b}$ & $\begin{array}{l}\text { Site Area or General } \\
\text { Emergency }^{c}\end{array}$ & & $\begin{array}{l}\text { ERPG-1 or } \\
\text { equivalent }\end{array}$ & $\begin{array}{l}\text { ERPG-2 or } \\
\text { equivalent }\end{array}$ & $\begin{array}{l}\text { ERPG-3 or } \\
\text { equivalent }\end{array}$ \\
\hline & $95 \%$ worst-case & $156(5)$ & $6.01(24)$ & $\mathrm{NSC}^{e}$ & 3 & 5 & Site Area & 1,200 & 834 & NLA $^{f}$ \\
\hline \multicolumn{11}{|l|}{ Direct } \\
\hline & Typical & $91.4(4)$ & $2.35(8)$ & NSC & 3 & 5 & Site Are & 656 & 500 & NLA \\
\hline
\end{tabular}

a. Protective action criteria are based on company guidelines for determining event classification. The definitions for event classifications of hazardous material releases at the INEL are discussed in the text.

b. The Alent protective action criteria value listed is the ERPG-1 equivalent ( $3{ }^{*}$ TLV-TWA) value for acetophenone.

c. The Site Area Emergency and General Emergency protective nction criteria value listed is the ERPG-2 equivalent (5*TLV-TWA) value for acetophenone.

d. The company guidelines for ERPGs and ERPG equivalents are discussed in the text. There is no ERPG-3 or equivalent concentration for acetophenone.

e. NSC stands for No Significant Consequences. The estimated airbome concentration was not significant at this receptor location or the ERPG (or equivalent) concentration was not exceeded at $100 \mathrm{~m}$.

f. NLA stands for No Limit Available. NLA indicates that an ERPG or equivalent concentration limit was not available for the hazardous material. 
Table C-5. Summary of event consequences for a release of acrylonitrile.

\begin{tabular}{|c|c|c|c|c|c|c|c|c|c|c|}
\hline \multirow[b]{2}{*}{ Release Type } & \multirow[b]{2}{*}{$\begin{array}{l}\text { Meteorological } \\
\text { conditions }\end{array}$} & \multicolumn{3}{|c|}{ 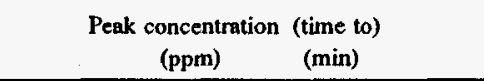 } & \multicolumn{2}{|c|}{$\begin{array}{c}\text { Protective action criteriag } \\
\text { (ppm) }\end{array}$} & \multirow{2}{*}{$\begin{array}{c}\text { Highest } \\
\text { emergency } \\
\text { class }\end{array}$} & \multicolumn{3}{|c|}{$\begin{array}{l}\text { Distance to ERPG or equivalent } \\
\text { (m) }\end{array}$} \\
\hline & & $100 \mathrm{~m}$ & $756 \mathrm{~m}$ & $5,200 \mathrm{~m}$ & Alert ${ }^{b}$ & $\begin{array}{l}\text { Site Area or General } \\
\text { Emergency }\end{array}$ & & $\begin{array}{l}\text { ERPG-1 or } \\
\text { equivalent }\end{array}$ & $\begin{array}{l}\text { ERPG-2 or } \\
\text { equivalent }\end{array}$ & $\begin{array}{l}\text { ERPG-3 or } \\
\text { equivalent }\end{array}$ \\
\hline & $95 \%$ worst-case & $725(4)$ & $25.5(21)$ & $\mathrm{NSC}^{\mathrm{e}}$ & 6 & 10 & Site Area & 1,900 & 1,400 & 119 \\
\hline \multicolumn{11}{|l|}{ Direct } \\
\hline & Typical & $379(3)$ & $10.1(5)$ & $0.277(20)$ & 6 & 10 & Site Area & 988 & 750 & NSC \\
\hline & $95 \%$ worst-case & $53.8(4)$ & $2.3(20)$ & $\mathrm{NSC}$ & 6 & 10 & Site Aren & 425 & 298 & NSC \\
\hline \multicolumn{11}{|l|}{ Spill } \\
\hline & Typical & $15(2)$ & $0.373(6)$ & $0.0187(42)$ & 6 & 10 & Site Area & 160 & 125 & NSC \\
\hline \multirow{3}{*}{ Spill w/ fire } & $95 \%$ worst-case & $732(3)$ & $26(23)$ & $\mathrm{NSC}$ & 6 & 10 & Site Area & 1,800 & 1,400 & 120 \\
\hline & & & & & & & & & & \\
\hline & Typical & $609(3)$ & $19.5(7)$ & NSC & 6 & 10 & Site Area & 1,400 & 1,100 & 112 \\
\hline
\end{tabular}

a. Protective action criteria are based on company guidelines for determining event classification. The definitions for event classifications of hazardous material releases at the INEL are discussed in the text.

b. The Alert protective action criteria value listed is the ERPG-1 equivalent (3*TLV-TWA) value for acrylonitrile

c. The Site Area Emergency and General Emergency protective action criteria value listed is the ERPG-2 equivalent (5*TWA-TLV) value for acrylonitrile.

d. The company guidelines for ERPGs and ERPG equivalents are discussed in the text. The ERPG-3 equivalent (IDLH) concentration of 500 ppm for acrylonitrile was used.

e. NSC stands for No Significant Consequences. The estimated airborne concentration was not significant at this receptor location or the ERPG (or equivalent) concentration was not exceeded at $100 \mathrm{~m}$. 
Table C-6. Summary of event consequences for a release of arsenic.

\begin{tabular}{|c|c|c|c|c|c|c|c|c|c|c|}
\hline \multirow[b]{2}{*}{ Release Type } & \multirow[b]{2}{*}{$\begin{array}{l}\text { Meteorological } \\
\text { conditions }\end{array}$} & \multicolumn{3}{|c|}{$\begin{array}{l}\text { Peak concentration (time to) } \\
\qquad\left(\mathrm{mg} / \mathrm{m}^{3}\right) \quad(\mathrm{min})\end{array}$} & \multicolumn{2}{|c|}{$\begin{array}{l}\text { Protective action criteria" } \\
\left(\mathrm{mg} / \mathrm{m}^{3}\right)\end{array}$} & \multirow{2}{*}{$\begin{array}{l}\text { Highest } \\
\text { emergency } \\
\text { class }\end{array}$} & \multicolumn{3}{|c|}{$\begin{array}{l}\text { Distance to ERPG or equivalent }{ }^{d} \\
(\mathrm{~m})\end{array}$} \\
\hline & & $100 \mathrm{~m}$ & $756 \mathrm{~m}$ & $5,200 \mathrm{~m}$ & Alent $^{b}$ & $\begin{array}{l}\text { Site Area or General } \\
\text { Emergency }{ }^{c}\end{array}$ & & $\begin{array}{l}\text { ERPG-1 or } \\
\text { equivalent }\end{array}$ & $\begin{array}{l}\text { ERPG-2 or } \\
\text { equivalent }\end{array}$ & $\begin{array}{l}\text { ERPG-3 or } \\
\text { equivalent }\end{array}$ \\
\hline & $95 \%$ worst-case & $0.25(2)$ & $1.8 \mathrm{E}-3(13)$ & $\mathrm{NSC}^{e}$ & 0.03 & 0.05 & Site Area & 240 & 190 & $\mathrm{NLA}^{\prime}$ \\
\hline \multicolumn{11}{|l|}{ Direct } \\
\hline & Typical & 0.04 (1) & $8.6 \mathrm{E}-4(5)$ & NSC & 0.03 & 0.05 & Alert & 125 & NSC & NLA \\
\hline
\end{tabular}

a. Protective action criteria are based on company guidelines for determining event classification. The definitions for event classifications of hazandous material releases at the INEL are discussed in the text.

b. The Alert protective action criteria value listed is the ERPG-1 equivalent ( $3 *$ TLV-TWA) value for arsenic.

c. The Site Area Emergency and General Emergency protective action criteria value listed is the ERPG-2 equivalent (5*TLV-TWA) value for argenic.

d. The company guidelines for ERPGs and ERPG equivalents are discussed in the text. There is no ERPG-3 or equivalent concentration for arsenic.

e. NSC stands for No Significant Consequences. The estimated airborne concentration was not significant at this receptor location or the ERPG (or equivalent) concentration was not exceeded at $100 \mathrm{~m}$.

f. NLA stands for No Limit Available. NLA indicates that an ERPG or equivalent concentration limit was not available for the hazardous material. 
Table C-7. Summary of event consequences for a release of asbestos.

\begin{tabular}{|c|c|c|c|c|c|c|c|c|c|c|}
\hline \multirow[b]{2}{*}{ Release Type } & \multirow[b]{2}{*}{$\begin{array}{c}\text { Meteorological } \\
\text { conditions }\end{array}$} & \multicolumn{3}{|c|}{$\begin{array}{c}\begin{array}{c}\text { Peak concentration (time to) } \\
\left(\mathbf{m g} / \mathbf{m}^{\mathbf{3}}\right) \quad(\mathbf{m i n})\end{array} \\
\end{array}$} & \multicolumn{2}{|c|}{$\begin{array}{c}\begin{array}{c}\text { Protective action criteria } \\
\left(\mathbf{m g} / \mathbf{m}^{2}\right)\end{array} \\
\end{array}$} & \multirow{2}{*}{$\begin{array}{c}\text { Highest } \\
\text { emergency } \\
\text { class }\end{array}$} & \multicolumn{3}{|c|}{$\begin{array}{l}\text { Distance to ERPG or equivalent } \\
\text { (m) }\end{array}$} \\
\hline & & $100 \mathrm{~m}$ & $756 \mathrm{~m}$ & $5,200 \mathrm{~m}$ & Alert $^{b}$ & $\begin{array}{c}\text { Site Area or General } \\
\text { Emergencyc }\end{array}$ & & $\begin{array}{l}\text { ERPG-1 or } \\
\text { equivalent }\end{array}$ & $\begin{array}{l}\text { ERPG-2 or } \\
\text { equivalent }\end{array}$ & $\begin{array}{l}\text { ERPG-3 or } \\
\text { equivalent }\end{array}$ \\
\hline & $95 \%$ worst-case & $0.25(2)$ & $1.8 \mathrm{E}-3(13)$ & $\mathrm{NSC}^{*}$ & 0.026 & 0.025 & Site Area & 250 & 250 & $\mathrm{NLA}^{\mathrm{f}}$ \\
\hline \multicolumn{11}{|l|}{ Direct } \\
\hline & Typical & $0.04(1)$ & $8.6 \mathrm{E}-4(5)$ & NSC & 0.026 & 0.025 & Site Area & 130 & 130 & NLA \\
\hline
\end{tabular}

a. Protective action criteria are based on company guidelines for determining event classification. The definitions for event classifications of hazardous material releases at the INEL, are discussed in the text.

b. The Alert protective action criteria value listed is the ERPG-I equivalent (TLV-STEL) value for asbestos.

c. The Site Area Emergency and General Emergency protective action criteria value listed is the ERPG-2 equivalent (5*TLV-TWA) value for asbestos.

d. The company guidelines for ERPGs and ERPG equivalents are discussed in the text. There is no ERPG-3 or equivalent concentration for asbestos.

e. NSC stands for No Significant Consequences. The estimated airborne concentration was not significant at this receptor location or the ERPG (or equivalent) concentration was not exceeded at $100 \mathrm{~m}$. 
Table C-8. Summary of event consequences for a release of barium.

\begin{tabular}{|c|c|c|c|c|c|c|c|c|c|c|}
\hline \multirow[b]{2}{*}{ Release Type } & \multirow[b]{2}{*}{$\begin{array}{l}\text { Meteorological } \\
\text { conditions }\end{array}$} & \multicolumn{3}{|c|}{$\begin{array}{l}\text { Peak concentration (time to) } \\
\left(\mathrm{mg} / \mathrm{m}^{3}\right) \quad(\mathrm{min})\end{array}$} & \multicolumn{2}{|c|}{$\begin{array}{l}\text { Protective action criterisa } \\
\left(\mathrm{mg} / \mathrm{m}^{3}\right)\end{array}$} & \multirow{2}{*}{$\begin{array}{c}\text { Highest } \\
\text { emergency } \\
\text { class }\end{array}$} & \multicolumn{3}{|c|}{$\begin{array}{l}\text { Distance to ERPG or equivalent } \\
(\mathrm{m})\end{array}$} \\
\hline & & $100 \mathrm{~m}$ & $756 \mathrm{~m}$ & $5,200 \mathrm{~m}$ & Alerr $^{6}$ & $\begin{array}{l}\text { Site Area or General } \\
\text { Emergency }\end{array}$ & & $\begin{array}{l}\text { ERPG-1 or } \\
\text { equivalent }\end{array}$ & $\begin{array}{l}\text { ERPG-2 or } \\
\text { equivalent }\end{array}$ & $\begin{array}{l}\text { ERPG.3 or } \\
\text { equivalent }\end{array}$ \\
\hline \multirow{3}{*}{ Direct } & $95 \%$ worst-case & $0.94(2)$ & $6.9 \mathrm{E}-3(13)$ & $\mathrm{NSC}^{*}$ & 1.5 & 2.5 & - & NSC & NSC & NSC \\
\hline & & & & & & & & & & \\
\hline & Typical & $0.15(1)$ & $3.2 \mathrm{E}-4(5)$ & NSC & 1.5 & 2.5 & . & NSC & NSC & NSC \\
\hline
\end{tabular}

a. Protective action criteria are based on company guidelines for determining event classification. The definitions for event classifications of hazardous material releases at the INEL are discussed in the text.

b. The Alert protective action criteria value listed is the ERPG-1 equivalent ( $3^{*}$ TLV-TWA) value for barium.

c. The Site Area Emergency and General Emergency protective action criteria value listed is the ERPG-2 equivalent (5*TLV-TWA) value for barium.

d. The company guidelines for ERPGs and ERPG equivalents are discussed in the text. The ERPG-3 equivalent (IDIH) concentration of $1,100 \mathrm{mg} / \mathrm{m}^{3}$ for barium was used.

e. NSC stands for No Significant Consequences. The estimated airbome concentration was not significant at this receptor location or the ERPG (or equivalent) concentration was not exceeded at $100 \mathrm{~m}$. 
Table C-9. Summary of event consequences for a release of benzene.

\begin{tabular}{|c|c|c|c|c|c|c|c|c|c|c|}
\hline \multirow[b]{2}{*}{ Release Type } & \multirow[b]{2}{*}{$\begin{array}{l}\text { Meteorological } \\
\text { conditions }\end{array}$} & \multicolumn{3}{|c|}{$\begin{array}{c}\begin{array}{c}\text { Peak concentration (time to) } \\
\text { (ppm) }\end{array} \\
\text { (min) }\end{array}$} & \multicolumn{2}{|c|}{$\begin{array}{c}\text { Protective action criterisa } \\
\text { (ppm) }\end{array}$} & \multirow{2}{*}{$\begin{array}{l}\text { Highest } \\
\text { emergency } \\
\text { class }\end{array}$} & \multicolumn{3}{|c|}{$\begin{array}{l}\text { Distance to ERPG or equivalent }{ }^{d} \\
\qquad(\mathrm{~m})\end{array}$} \\
\hline & & $100 \mathrm{~m}$ & $756 \mathrm{~m}$ & $5,200 \mathrm{~m}$ & Alert $^{b}$ & $\begin{array}{l}\text { Site Area or General } \\
\text { Emergencyc }\end{array}$ & & $\begin{array}{l}\text { ERPG-1 or } \\
\text { equivalent }\end{array}$ & $\begin{array}{l}\text { ERPG-2 or } \\
\text { equivalent }\end{array}$ & $\begin{array}{l}\text { ERPG-3 or } \\
\text { equivalent }\end{array}$ \\
\hline & $95 \%$ worst-case & $1.63(5)$ & $\mathrm{NSC}^{+}$ & NSC & 5 & 5 & - & NSC & NSC & $\mathrm{NSC}$ \\
\hline \multicolumn{11}{|l|}{ Direct } \\
\hline & Typical & $0.334(4)$ & NSC & NSC & 5 & 5 & - & NSC & NSC & NSC \\
\hline \multirow{3}{*}{ Spill } & $95 \%$ worst-case & $9.79(5)$ & NSC & $\mathrm{NSC}$ & 5 & 5 & Site Area & 160 & 160 & NsC \\
\hline & . & & & & & & & & & \\
\hline & Typical & $1.7(5)$ & NSC & NSC & 5 & 5 & - & NSC & NSC & NSC \\
\hline \multirow{3}{*}{ Spill w/ fire } & $95 \%$ worst-case & $74.9(4)$ & $2.25(18)$ & NSC & 5 & 5 & Site Area & 490 & 490 & NSC \\
\hline & & & & & & & & & & \\
\hline & Typical & $72(3)$ & $1.27(6)$ & NSC & 5 & 5 & Site Area & 400 & 400 & NSC \\
\hline
\end{tabular}

a. Protective action criteria are based on company guidelines for determining event classification. The definitions for event classifications of hazardous material releases at the INEL, are discussed in the text.

b. The Alert protective action criteria value listed is the ERPG-1 equivalent (TLV.STEL) value for benzene.

c. The Site Area Emergency and General Emergency protective action criteria value listed is the ERPG-2 equivalent (5*TLV-TWA) value for benzene.

d. The company guidelines for ERPGs and ERPG equivalents are discussed in the text. The ERPG-3 equivalent (IDLH) concentration of 3,000 ppm for benzene was used.

e. NSC stands for No Significant Consequences. The estimated airome concentration was not significant at this receptor location or the ERPG (or equivalent) concentration was not exceeded at $100 \mathrm{~m}$. 
Table C-10. Summary of event consequences for a release of benzoic acid.

\begin{tabular}{|c|c|c|c|c|c|c|c|c|c|c|}
\hline \multirow[b]{2}{*}{ Release Type } & \multirow[b]{2}{*}{$\begin{array}{c}\begin{array}{c}\text { Meteorological } \\
\text { conditions }\end{array} \\
\end{array}$} & \multicolumn{3}{|c|}{$\begin{array}{c}\begin{array}{c}\text { Peak concentration (time to) } \\
(\mathrm{ppm}) \quad(\mathrm{min})\end{array} \\
\end{array}$} & \multicolumn{2}{|c|}{$\begin{array}{c}\text { Prolective action criterisa } \\
\text { (ppm) }\end{array}$} & \multirow{2}{*}{$\begin{array}{c}\text { Highest } \\
\text { emergency } \\
\text { class }\end{array}$} & \multicolumn{3}{|c|}{$\begin{array}{l}\text { Distance to ERPG or equivalent }{ }^{d} \\
(\mathrm{~m})\end{array}$} \\
\hline & & $100 \mathrm{~m}$ & $756 \mathrm{~m}$ & $5,200 \mathrm{~m}$ & Alert $^{b}$ & $\begin{array}{l}\text { Site Area or General } \\
\text { Emergency }{ }^{c}\end{array}$ & & $\begin{array}{l}\text { ERPG-1 or } \\
\text { equivalent }\end{array}$ & $\begin{array}{l}\text { ERPG-2 or } \\
\text { equivalent }\end{array}$ & $\begin{array}{l}\text { ERPG-3 or } \\
\text { equivalent }\end{array}$ \\
\hline & $95 \%$ worst-case & $154(6)$ & $5.91(23)$ & $\mathrm{NSC}^{\mathrm{e}}$ & 30 & 50 & Sile Area & 260 & 193 & NLA $^{f}$ \\
\hline \multicolumn{11}{|l|}{ Direct } \\
\hline & Typical & $86.9(4)$ & $2.15(10)$ & NSC & 30 & 50 & Site Area & 163 & 127 & NLA \\
\hline
\end{tabular}

a. Protective action criteria are based on company guidelines for determining event classification. The definitions for event classifications of hazardous material releases at the INEL are discussed in the text.

b. The Alert protective action criteria value listed is the ERPG-1 equivalent (estimated by WERF IH) value for benzoic acid.

c. The Site Area Emergency and General Emergency protective action criteria value listed is the ERPG-2 equivalent (estimated by WERF IH) value for benzoic acid.

d. The company guidelines for ERPGs and ERPG equivalents are discussed in the text. There is no ERPG-3 or equivalent concentration for benzoic acid.

e. NSC stends for No Significant Consequences. The estimated airborne concentration was .not significant at this receptor location or the ERPG (or equivalent) concentration was not exceeded at $100 \mathrm{~m}$.

f. NLA stands for No Limit Available. NLA indicales that an ERPG or equivalent concentration limit was not available for the hazardous material. 
Table C-11. Summary of event consequences for a release of benzo[a]anthracene.

\begin{tabular}{|c|c|c|c|c|c|c|c|c|c|c|}
\hline \multirow[b]{2}{*}{ Release Type } & \multirow[b]{2}{*}{$\begin{array}{c}\text { Meteorological } \\
\text { conditions } \\
\end{array}$} & \multicolumn{3}{|c|}{$\begin{array}{l}\text { Peak concentration (time to) } \\
\left(\mathrm{mg} / \mathrm{m}^{3}\right) \quad(\mathrm{min})\end{array}$} & \multicolumn{2}{|c|}{$\begin{array}{l}\text { Protective action criteria } \\
\left(\mathrm{mg} / \mathrm{m}^{\mathrm{a}}\right)\end{array}$} & \multirow{2}{*}{$\begin{array}{l}\text { Highest } \\
\text { emergency } \\
\text { class }\end{array}$} & \multicolumn{3}{|c|}{$\begin{array}{l}\text { Distance to ERPG or equivalent } \\
\text { (m) }\end{array}$} \\
\hline & & $100 \mathrm{~m}$ & $756 \mathrm{~m}$ & $5,200 \mathrm{~m}$ & Alert $^{b}$ & $\begin{array}{c}\text { Site Area or General } \\
\text { Emergency }^{c}\end{array}$ & & $\begin{array}{l}\text { ERPG-1 or } \\
\text { equivalent }\end{array}$ & $\begin{array}{l}\text { ERPG-2 or } \\
\text { equivalent }\end{array}$ & $\begin{array}{l}\text { ERPG-3 or } \\
\text { equivalent }\end{array}$ \\
\hline & $95 \%$ worst-case & $8.11(4)$ & $0.17(20)$ & $\mathrm{NSC}^{e}$ & 0.6 & 1 & Site Area & 385 & 295 & $\mathrm{NLA}^{f}$ \\
\hline \multicolumn{11}{|l|}{ Direct } \\
\hline & Typical & $0.45(2)$ & NSC & NSC & 0.6 & 1 & - & NSC & NSC & NLA \\
\hline
\end{tabular}

a. Protective action criteria are based on company guidelines for determining event classification. The defintions for event classifications of hazardous material releases at the INEL are discussed in the text.

b. The Alert protective action criteria value listed is the ERPG-1 equivalent (estimated by WERF IH) value for benzola]anthracene.

c. The Site Area Emergency and General Emergency protective action criteria value listed is the ERPG-2 equivalent (estimated by WERF IH) value for benzo[a]anthracene.

d. The company guidelines for ERPGis and ERPG equivalents are discussed in the text. There is no ERPG-3 or equivalent concentration for benzo[a]anthracene.

e. NSC stands for No Significant Consequences. The estimated airborme concentration was not significant at this receptor location or the ERPG (or equivalent) concentration was not exceeded at $100 \mathrm{~m}$.

f. NLA stands for No Limit Available. NLA indicates that an ERPG or equivalent concentration limit was not available for the hazardous material. 
Table C-12. Summary of event consequences for a release of benzo[a]pyrene.

\begin{tabular}{|c|c|c|c|c|c|c|c|c|c|c|}
\hline \multirow[b]{2}{*}{ Release Type } & \multirow[b]{2}{*}{$\begin{array}{l}\text { Meteorological } \\
\text { conditions }\end{array}$} & \multicolumn{3}{|c|}{ 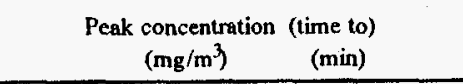 } & \multicolumn{2}{|c|}{$\begin{array}{c}\text { Protective action criteria } \\
\left(\mathbf{m g} / \mathbf{m}^{3}\right)\end{array}$} & \multirow{2}{*}{$\begin{array}{c}\text { Highest } \\
\text { emergency } \\
\text { class }\end{array}$} & \multicolumn{3}{|c|}{$\begin{array}{l}\text { Distance to ERPG or equivalent }{ }^{d} \\
(\mathbf{m})\end{array}$} \\
\hline & & $100 \mathrm{~m}$ & $756 \mathrm{~m}$ & $5,200 \mathrm{~m}$ & Alerr ${ }^{b}$ & $\begin{array}{l}\text { Site Area or General } \\
\text { Emergency }{ }^{c}\end{array}$ & & $\begin{array}{l}\text { ERPG-1 or } \\
\text { equivalent }\end{array}$ & $\begin{array}{l}\text { ERPG-2 or } \\
\text { equivalent }\end{array}$ & $\begin{array}{l}\text { ERPG-3 or } \\
\text { equivalent }\end{array}$ \\
\hline \multirow{3}{*}{ Direct } & $95 \%$ worst-case & $0.25(2)$ & $1.8 \mathrm{E}-3(13)$ & $\mathrm{NSC}^{\mathrm{e}}$ & $\mathrm{NLA}^{\mathrm{f}}$ & NLA & - & NLA & NLA & NLA \\
\hline & & & & & & & & & & \\
\hline & Typical & $0.04(1)$ & $8.6 \mathrm{E}-4(5)$ & NSC & NLA & NLA & - & NLA & NLA & NLA \\
\hline
\end{tabular}

a. Protective action criteria are based on company guidelines for determining event classification. The definitions for event classifications of hazardous material releases at the INEL are discussed in the text.

b. There is no Alert protective action criteria value listed for benzo[a]pyrene.

c. There is no Site Area Emergency or General Emergency protective action criteria value listed for benzo[alpyrene.

d. The company guidelines for ERPGs and ERPG equivalents are discussed in the text. There is no ERPG-3 or equivalent concentration for benzo[a]pyrene.

e. NSC stands for No Significant Consequences. The estimated airborne concentration was not significant at this receptor location or the ERPG (or equivalent) concentration was not exceoded at $100 \mathrm{~m}$.

f. NLA stands for No Limit Available. NLA indicates that an ERPG or equivalent concentration limit was not available for the hazardous material. 
Table C-13. Summary of event consequences for a release of benzo[b]fluoranthene.

\begin{tabular}{|c|c|c|c|c|c|c|c|c|c|c|}
\hline \multirow[b]{2}{*}{ Release Type } & \multirow[b]{2}{*}{$\begin{array}{l}\text { Meteorological } \\
\text { conditions }\end{array}$} & \multicolumn{3}{|c|}{$\begin{array}{l}\begin{array}{l}\text { Peak concentration (time to) } \\
(\mathrm{ppm})\end{array} \quad(\mathrm{min}) \\
\end{array}$} & \multicolumn{2}{|c|}{$\begin{array}{l}\text { Protective action criterian } \\
\text { (ppm) }\end{array}$} & \multirow{2}{*}{$\begin{array}{c}\text { Highest } \\
\text { emergency } \\
\text { class }\end{array}$} & \multicolumn{3}{|c|}{$\begin{array}{l}\text { Distance to ERPG or equivalent } \\
\text { (m) }\end{array}$} \\
\hline & & $100 \mathrm{~m}$ & $756 \mathrm{~m}$ & $5,200 \mathrm{~m}$ & Aler $^{b}$ & $\begin{array}{l}\text { Site Area or General } \\
\text { Emergency }{ }^{c}\end{array}$ & & $\begin{array}{l}\text { ERPG-1 or } \\
\text { equivalent }\end{array}$ & $\begin{array}{l}\text { ERPG-2 or } \\
\text { equivalent }\end{array}$ & $\begin{array}{l}\text { ERPG-3 or } \\
\text { equivalent }\end{array}$ \\
\hline \multirow{3}{*}{ Direct } & $95 \%$ worst-case & $0.08(4)$ & $\mathrm{NSC}^{\mathrm{e}}$ & NSC & 15 & 25 & - & NSC & NSC & NLA $^{f}$ \\
\hline & & & & & & & & & & \\
\hline & Typical & $0.004(3)$ & NSC & NSC & 15 & 25 & - & NSC & NSC & NLA \\
\hline
\end{tabular}

a. Protective action criteria are based on company guidelines for determining event classification. The definitions for event classifications of hazandous material releases at the INEL are discussed in the text.

b. The Alert protective action criteria value listed is the ERPG-1 equivalent (estimated by WERF IH) value for benzo(b]fluoranthene.

c. The Site Area Emergency and General Emergency protective action criteria value listed is the ERPG-2 equivalent (estimated by WERF IH) value for benzo[b]fluoranthene.

d. The company guidelines for ERPGs and ERPG equivalents are discussed in the text. There is no ERPG-3 or equivalent concentration for benzolb]fluoranthene.

e. NSC stands for No Significant Consequences. The estimated airborme concentration was not significant at this receptor location or the ERPG (or equivalent) concentration was not exceeded at $100 \mathrm{~m}$. 
Table C-14. Summary of event consequences for a release of benzo[g,h,i]perylene.

\begin{tabular}{|c|c|c|c|c|c|c|c|c|c|c|}
\hline \multirow[b]{2}{*}{ Release Type } & \multirow[b]{2}{*}{$\begin{array}{l}\text { Meteorological } \\
\text { conditions }\end{array}$} & \multicolumn{3}{|c|}{$\begin{array}{l}\text { Peak concentration (time to) } \\
\begin{array}{c}(\mathrm{ppm}) \\
(\mathrm{min})\end{array}\end{array}$} & \multicolumn{2}{|c|}{$\begin{array}{l}\text { Protective action criteria" } \\
\text { (ppm) }\end{array}$} & \multirow{2}{*}{$\begin{array}{c}\text { Highest } \\
\text { emergency } \\
\text { class }\end{array}$} & \multicolumn{3}{|c|}{$\begin{array}{l}\text { Distance to ERPG or equivalent } \\
(\mathrm{m})\end{array}$} \\
\hline & & $100 \mathrm{~m}$ & $756 \mathrm{~m}$ & $5,200 \mathrm{~m}$ & Alert $^{b}$ & $\begin{array}{l}\text { Site Area or General } \\
\text { Emergency }{ }^{c}\end{array}$ & & $\begin{array}{l}\text { ERPG-1 or } \\
\text { equivalent }\end{array}$ & $\begin{array}{l}\text { ERPG-2 or } \\
\text { equivalent }\end{array}$ & $\begin{array}{l}\text { ERPG-3 or } \\
\text { equivalent }\end{array}$ \\
\hline \multirow{3}{*}{ Direct } & $95 \%$ worst-case & $353(3)$ & $7.59(14)$ & $\mathrm{NSC}^{e}$ & 15 & 25 & Site Area & 519 & 396 & NLA $^{f}$ \\
\hline & & & & & & & & & & \\
\hline & Typical & $19.6(2)$ & $0.48(8)$ & NSC & 15 & 25 & Alert & 116 & NSC & NLA \\
\hline
\end{tabular}

a. Protective action criteria are based on company guidelines for determining event classification. The definitions for event classifications of hazardous material releases at the INEL are diacussed in the text.

b. The Alert protective action criteria value listed is the ERPG-I equivalent (estimated by WERF IH) value for benzolg,h,ijperylene.

c. The Site Area Emergency and General Emergency protective action criteria value listed is the ERPG-2 equivalent (estimated by WERF IH) value for benzo[g,h,i]perylene.

d. The company guidelines for ERPGs and ERPG equivalents are discussed in the text. There is no ERPG-3 or equivalent concentration for benzo[g,h,ilperylene.

e. NSC stands for No Significant Consequences. The estimated airborne concentration was not significant at this receptor location or the ERPG (or equivalent) concentration was not exceeded at $100 \mathrm{~m}$.

f. NLA stands for No Limit Available. NLA indicates that an ERPG or equivalent concentration limit was not available for the hazardous material. 
Table C-15. Summary of event consequences for a release of beryllium.

\begin{tabular}{|c|c|c|c|c|c|c|c|c|c|c|}
\hline \multirow[b]{2}{*}{ Release Type } & \multirow[b]{2}{*}{$\begin{array}{l}\text { Meteorological } \\
\text { conditions }\end{array}$} & \multicolumn{3}{|c|}{$\begin{array}{c}\begin{array}{c}\text { Peak concentration (time to) } \\
\left(\mathbf{m g} / \mathbf{m}^{3}\right)\end{array} \quad(\mathrm{min}) \\
\end{array}$} & \multicolumn{2}{|c|}{$\begin{array}{l}\text { Protective action criteriag } \\
(\mathrm{ppm})\end{array}$} & \multirow{2}{*}{$\begin{array}{l}\text { Highest } \\
\text { emergency } \\
\text { class }\end{array}$} & \multicolumn{3}{|c|}{$\begin{array}{l}\text { Distance to ERPG or equivalent } \\
\text { (m) }\end{array}$} \\
\hline & & $100 \mathrm{~m}$ & $756 \mathrm{~m}$ & $5,200 \mathrm{~m}$ & Alert ${ }^{b}$ & $\begin{array}{l}\text { Site Area or General } \\
\text { Emergency }{ }^{c}\end{array}$ & & $\begin{array}{l}\text { ERPG-1 or } \\
\text { equivalent }\end{array}$ & $\begin{array}{l}\text { ERPG-2 or } \\
\text { equivalent }\end{array}$ & $\begin{array}{l}\text { ERPG-3 or } \\
\text { equivalent }\end{array}$ \\
\hline \multirow{3}{*}{ Direct } & $95 \%$ worst-case & $2.5(2)$ & $0.018(13)$ & $\mathrm{NSC}^{\mathrm{e}}$ & $\mathrm{NLA}^{\mathrm{f}}$ & 25 & - & NLA & NSC & NSC \\
\hline & & & & & & & & & & \\
\hline & Typical & $0.4(1)$ & $8.6 \mathrm{E}-3(5)$ & NSC & NLA & 25 & - & NLA & NSC & NSC \\
\hline
\end{tabular}

a. Protective action criteria are based on company guidelines for determining event classification. The definitions for event classifications of hazardous material releases at the INEL are discussed in the text.

b. There is no Alert protective action criteria value listed for beryllium.

c. The Site Area Emergency and General Emergency protective action criteria value listed is the draft ERPG-2 value for beryllium.

d. The company guidelines for ERPGs and ERPG equivalents are discussed in the text. The draft ERPG-3 concentration of 100 ppm for beryllium was used

e. NSC stands for No Significant Consequences. The estimated airbome concentration was not significant at this receptor location or the ERPG (or equivalent) concentration was not exceeded at $100 \mathrm{~m}$.

f. NLA stands for No Limit Available. NLA indicates that an ERPG or equivalent concentration limit was not available for the hazardous material. 
Table C-16. Summary of event consequences for a release of bis(2-ethylhexyl) phthalate.

\begin{tabular}{|c|c|c|c|c|c|c|c|c|c|c|}
\hline \multirow[b]{2}{*}{ Release Type } & \multirow[b]{2}{*}{$\begin{array}{l}\text { Meteorological } \\
\text { conditions }\end{array}$} & \multicolumn{3}{|c|}{$\begin{array}{l}\begin{array}{l}\text { Peak concentration (time to }) \\
\left(\mathrm{mg} / \mathrm{m}^{3}\right)\end{array} \quad(\mathrm{min}) \\
\end{array}$} & \multicolumn{2}{|c|}{$\begin{array}{c}\text { Protective action criteria" } \\
\left(\mathrm{mg} / \mathrm{m}^{3}\right)\end{array}$} & \multirow{2}{*}{$\begin{array}{c}\text { Highest } \\
\text { emergency } \\
\text { class }\end{array}$} & \multicolumn{3}{|c|}{$\begin{array}{l}\text { Distance to ERPG or equivalent } \\
\text { (m) }\end{array}$} \\
\hline & & $100 \mathrm{~m}$ & $756 \mathrm{~m}$ & $5,200 \mathrm{~m}$ & Alert ${ }^{b}$ & $\begin{array}{l}\text { Site Area or General } \\
\text { Emergency }{ }^{c}\end{array}$ & & $\begin{array}{l}\text { ERPG.1 or } \\
\text { equivalent }\end{array}$ & $\begin{array}{l}\text { ERPG-2 or } \\
\text { equivalent }\end{array}$ & $\begin{array}{l}\text { ERPG-3 or } \\
\text { equivalent }\end{array}$ \\
\hline . & $95 \%$ worst-case & $72(2)$ & $1.4(13)$ & $\mathrm{NSC}^{\mathrm{e}}$ & 10 & 25 & Site Area & 260 & 160 & $\mathrm{NLA}^{\mathrm{f}}$ \\
\hline \multicolumn{11}{|l|}{ Direct } \\
\hline & Typical & $4.4(1)$ & NSC & NSC & 10 & 25 & . & $\mathrm{NSC}$ & NSC & NLA \\
\hline
\end{tabular}

a. Protective action criteria are based on company guidelines for determining event classification. The definitions for event classifications of hazardous material releases at the INEL are discussed in the text.

b. The Alen protective action criteria value listed is the ERPG-1 equivalent (TLV-STEL) value for bis(2-ethylhexyl) phthalate.

c. The Site Area Emergency and General Emergency protective action criteria value listed is the ERPG-2 equivalent (5*TLV-TWA) value for bis(2-ethylhexyl) phthalate.

d. The company guidelines for ERPGs and ERPG equivalents are discussed in the text. There is no ERPG-3 or equivalent concentration for bis(2-ethylhexyl) phthalate.

e. NSC stands for No Significant Consequences. The estimated airbome concentration was not significant at this receptor location or the ERPG (or equivalent) concentration was not exceeded at $100 \mathrm{~m}$.

f. NLA stands for No Limit Available. NLA indicates that an ERPG or equivalent concentration limit was not available for the hazardous material. 


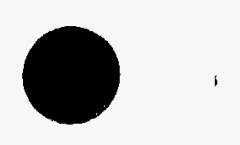

Table C-17. Summary of event consequences for a release of butyl/benzylphthalate (1,2 benzene dicarboxylic acid).

\begin{tabular}{|c|c|c|c|c|c|c|c|c|c|c|}
\hline \multirow[b]{2}{*}{ Release Type } & \multirow[b]{2}{*}{$\begin{array}{l}\text { Meteorological } \\
\text { conditions }\end{array}$} & \multicolumn{3}{|c|}{$\begin{array}{cc}\begin{array}{c}\text { Peak concentration (time to) } \\
(\text { ppm) }\end{array} & (\mathrm{min}) \\
\end{array}$} & \multicolumn{2}{|c|}{$\begin{array}{l}\text { Prolective action criteriat } \\
\text { (ppm) }\end{array}$} & \multirow{2}{*}{$\begin{array}{c}\text { Highest } \\
\text { emergency } \\
\text { class }\end{array}$} & \multicolumn{3}{|c|}{$\begin{array}{l}\text { Distance to ERPG or equivalent } \\
\text { (m) }\end{array}$} \\
\hline & & $100 \mathrm{~m}$ & $756 \mathrm{~m}$ & $5,200 \mathrm{~m}$ & Alert & $\begin{array}{l}\text { Site Asea or General } \\
\text { Emergency }{ }^{c}\end{array}$ & & $\begin{array}{l}\text { ERPG-1 or } \\
\text { equivalent }\end{array}$ & $\begin{array}{l}\text { ERPG-2 or } \\
\text { equivalent }\end{array}$ & $\begin{array}{l}\text { ERPG-3 or } \\
\text { equivalent }\end{array}$ \\
\hline & $95 \%$ worst-case & $624(4)$ & $13.4(18)$ & $\mathrm{NSC}^{\mathrm{e}}$ & 5 & 15 & Site Area & 1,300 & 711 & $\mathrm{NLA}^{\mathrm{f}}$ \\
\hline \multicolumn{11}{|l|}{ Direct } \\
\hline & Typical & $34.7(2)$ & $0.85(10)$ & NSC & 5 & 15 & Sile Area & 279 & 155 & NLA \\
\hline
\end{tabular}

a. Protective action criteria are based on company guidelines for determining event classification. The definitions for event classifications of hazardous material releases at the INEL are discussed in the text.

b. The Alert protective action criteria value listed is the ERPG-1 equivalent (TLV-STEL) value for 1,2 benzene dicarboxylic acid.

c. The Site Area Emergency and General Emergency protective action criteria value listed is the ERPG-2 equivalent ( $5^{*} \mathrm{TLV}$-TWA) value for 1,2 benzene dicarboxylic acid.

d. The company guidelines for ERPGs and ERPG equivalents are discussed in the text. There is no ERPG-3 or equivalent concentration for 1,2 benzene dicarboxylic acid.

e. NSC stands for No Significant Consequences. The estimated airborne concentration was not significant at this receptor location or the ERPG (or equivalent) concentration was not exceeded at $100 \mathrm{~m}$.

f. NLA stands for No Limit Available. NLA indicates that an ERPG or equivalent concentration limit was not available for the hazardous material. 
Table C-18. Summary of event consequences for a release of cadmium.

\begin{tabular}{|c|c|c|c|c|c|c|c|c|c|c|}
\hline \multirow[b]{2}{*}{ Release Type } & \multirow[b]{2}{*}{$\begin{array}{l}\text { Meteorological } \\
\text { conditions }\end{array}$} & \multicolumn{3}{|c|}{$\begin{array}{c}\begin{array}{c}\text { Peak concentration (time to) } \\
\left(\mathrm{mg} / \mathrm{m}^{3}\right)\end{array} \quad(\mathrm{min}) \\
\end{array}$} & \multicolumn{2}{|c|}{$\begin{array}{c}\text { Protective action criterian } \\
\left(\mathrm{mg} / \mathrm{m}^{3}\right)\end{array}$} & \multirow{2}{*}{$\begin{array}{l}\text { Highest } \\
\text { emergency } \\
\text { class }\end{array}$} & \multicolumn{3}{|c|}{$\begin{array}{l}\text { Distance to ERPG or equivalent }{ }^{d} \\
(\mathbf{m})\end{array}$} \\
\hline & & $100 \mathrm{~m}$ & $756 \mathrm{~m}$ & $5,200 \mathrm{~m}$ & Alert & $\begin{array}{l}\text { Site Area or General } \\
\text { Emergency }{ }^{c}\end{array}$ & & $\begin{array}{l}\text { ERPG-1 or } \\
\text { equivalent }\end{array}$ & $\begin{array}{l}\text { ERPG-2 or } \\
\text { equivalent }\end{array}$ & $\begin{array}{l}\text { ERPG-3 or } \\
\text { equivalent }\end{array}$ \\
\hline & $95 \%$ worst-case & $2.5(2)$ & $0.018(13)$ & $\mathrm{NSC}^{\epsilon}$ & 0.6 & 1.0 & Sile Area & 602 & 496 & NSC \\
\hline \multicolumn{11}{|l|}{ Direct } \\
\hline & Typical & $0.4(1)$ & $8.6 E-3(5)$ & NSC & 0.6 & 1.0 & Site Area & NSC & NSC & NSC \\
\hline
\end{tabular}

a. Protective action criteria are based on company guidelines for determining event classification. The definitions for event classifications of hazardous material releases at the INEL are discussed in the text.

b. The Alert protective action criterin value listed is the ERPG-1 equivalent ( $3^{*}$ TLV-TWA) value for cadmium.

c. The Site Area Emergency and General Emergency protective action criteria value listed is the ERPG-2 equivalent (5*TLV-TWA) value for cadmium.

d. The company guidelines for ERPGs and ERPG equivalents are discussed in the text. The ERPG-3 equivalent (IDLH) concentration of $50 \mathrm{mg} / \mathrm{m}^{3}$ for cadmium was used.

e. NSC stands for No Significant Consequences. The estimated airbome concentration was not significant at this receptor location or the ERPG (or equivalent) concentration was not exceeded at $100 \mathrm{~m}$. 
Table C-19. Summary of event consequences for a release of carbon tetrachloride.

\begin{tabular}{|c|c|c|c|c|c|c|c|c|c|c|}
\hline \multirow[b]{2}{*}{ Release Type } & \multirow[b]{2}{*}{$\begin{array}{l}\text { Meteorological } \\
\text { conditions }\end{array}$} & \multicolumn{3}{|c|}{$\begin{array}{l}\text { Peak concentration (time to) } \\
\quad(\mathrm{ppm}) \quad(\mathrm{min})\end{array}$} & \multicolumn{2}{|c|}{$\begin{array}{l}\text { Protective action criteria } \\
(\mathrm{ppm})\end{array}$} & \multirow{2}{*}{$\begin{array}{c}\text { Highest } \\
\text { emergency } \\
\text { class }\end{array}$} & \multicolumn{3}{|c|}{$\begin{array}{l}\text { Distance to ERPG or equivalent }{ }^{d} \\
\text { (m) }\end{array}$} \\
\hline & & $100 \mathrm{~m}$ & $756 \mathrm{~m}$ & $5,200 \mathrm{~m}$ & Alert ${ }^{b}$ & $\begin{array}{l}\text { Site Area or General } \\
\text { Emergency }\end{array}$ & & $\begin{array}{l}\text { ERPG-1 or } \\
\text { equivalent }\end{array}$ & $\begin{array}{l}\text { ERPG-2 or } \\
\text { equivalent }\end{array}$ & $\begin{array}{l}\text { ERPG-3 or } \\
\text { equivalent }\end{array}$ \\
\hline & $95 \%$ worst-case & $0.853(5)$ & $\mathrm{NSC}^{\mathrm{e}}$ & NSC & 20 & 100 & - & NSC & NSC & NSC \\
\hline \multicolumn{11}{|l|}{ Direct } \\
\hline & Typical & $0.164(5)$ & NSC & NSC & 20 & 100 & . & NSC & NSC & NSC \\
\hline & $95 \%$ worst-case & $5.1(5)$ & NSC & NSC & 20 & 100 & - & NSC & NSC & NSC \\
\hline \multicolumn{11}{|l|}{ Spill } \\
\hline & Typical & $1.08(2)$ & NSC & NSC & 20 & 100 & - & $\mathrm{NSC}$ & $\mathrm{NSC}$ & NSC \\
\hline & $95 \%$ worst-case & $35.6(4)$ & NSC & NSC & 20 & 100 & Alert & 110 & NSC & NSC \\
\hline \multicolumn{11}{|l|}{ Spill w/ fire } \\
\hline & Typical & $29.8(3)$ & NSC & NSC & 20 & 100 & Alent & 100 & NSC & NSC \\
\hline
\end{tabular}

a. Protective action criteria are based on company guidelines for determining event classification. The definitions for event classifications of hazardous material releases at the INEL are discussed in the text.

b. The Alert protective action criteria value listed is the ERPG-1 value for carbon tetrachloride.

c. The Site Area Emergency and General Emergency protective action criteria value listed is the ERPG-2 value for carbon tetrachloride.

d. The company guidelines for ERPGs and ERPG equivalents are discussed in the text. The ERPG-3 concentration of 750 ppm for carbon tetrachloride was used.

e. NSC stands for No Significant Consequences. The estimated airborme concentration was not significant at this receptor location or the ERPG (or equivalent) concentration was not exceeded at $100 \mathrm{~m}$. 
Table C-20. Summary of event consequences for a release of chlordane.

\begin{tabular}{|c|c|c|c|c|c|c|c|c|c|c|}
\hline \multirow[b]{2}{*}{ Release Type } & \multirow[b]{2}{*}{$\begin{array}{l}\text { Meteorological } \\
\text { conditions }\end{array}$} & \multicolumn{3}{|c|}{$\begin{array}{cc}\begin{array}{c}\text { Peak concentration } \\
(\text { time to }) \\
\left(\mathrm{mg} / \mathrm{m}^{3}\right)\end{array} \quad(\mathrm{min}) \\
\end{array}$} & \multicolumn{2}{|c|}{$\begin{array}{l}\text { Protective action criterisa } \\
\left(\mathrm{mg} / \mathrm{m}^{3}\right)\end{array}$} & \multirow{2}{*}{$\begin{array}{c}\text { Highest } \\
\text { emergency } \\
\text { class }\end{array}$} & \multicolumn{3}{|c|}{$\begin{array}{l}\text { Distance to ERPG or equivalent }{ }^{d} \\
(\mathrm{~m})\end{array}$} \\
\hline & & $100 \mathrm{~m}$ & $756 \mathrm{~m}$ & $5,200 \mathrm{~m}$ & Alert ${ }^{6}$ & $\begin{array}{l}\text { Sire Area or General } \\
\text { Emergency }\end{array}$ & & $\begin{array}{l}\text { ERPG-1 or } \\
\text { equivalent }\end{array}$ & $\begin{array}{l}\text { ERPG-2 or } \\
\text { equivalent }\end{array}$ & $\begin{array}{l}\text { ERPG.3 or } \\
\text { equivalent }\end{array}$ \\
\hline \multirow{3}{*}{ Direct } & $95 \%$ worst-case & $250(2)$ & $1.8(13)$ & $0.018(87)$ & 1.5 & 2.5 & Site Area & 810 & 650 & $\mathrm{NSC}^{*}$ \\
\hline & & & & & & & & & & \\
\hline & Typical & $40(1)$ & $0.86(5)$ & NSC & 1.5 & 2.5 & Site Area & 550 & 420 & NSC \\
\hline
\end{tabular}

a. Protective action criteria are based on company guidelines for determining event classification. The definitions for event classifications of hazardous mnterial releases at the INEL are discussed in the text.

b. The Alert protective action criteria value listed is the ERPG-1 equivalent (3*TLV-TWA) value for chlordane.

c. The Site Area Emergency and General Emergency protective action criteria value listed is the ERPG-2 equivalent (5*TLV-TWA) value for chlordane.

d. The company guidelines for ERPGs and ERPG equivalents are discussed in the text. The ERPG-3 equivalent (IDLH) concentration of $500 \mathrm{mg} / \mathrm{m}^{3}$ for chlordane was used.

e. NSC stands for No Significant Consequences. The estimated airborne concentration was not significant at this receptor location or the ERPG (or equivalent) concentration was not exceeded at $100 \mathrm{~m}$. 
Table C-21. Summary of event consequences for a release of chlorine.

\begin{tabular}{|c|c|c|c|c|c|c|c|c|c|c|}
\hline \multirow[b]{2}{*}{ Release Type } & \multirow[b]{2}{*}{$\begin{array}{l}\text { Meteorological } \\
\text { conditions }\end{array}$} & \multicolumn{3}{|c|}{ 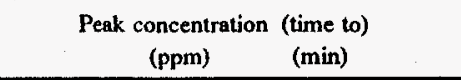 } & \multicolumn{2}{|c|}{$\begin{array}{l}\text { Protective nction criterisa } \\
\text { (ppm) }\end{array}$} & \multirow{2}{*}{$\begin{array}{c}\text { Highest } \\
\text { emergency } \\
\text { class }\end{array}$} & \multicolumn{3}{|c|}{$\begin{array}{l}\text { Distance to ERPG or equivalent }{ }^{d} \\
\text { (m) }\end{array}$} \\
\hline & & $100 \mathrm{~m}$ & $756 \mathrm{~m}$ & $5,200 \mathrm{~m}$ & Alert $^{b}$ & $\begin{array}{l}\text { Site Area or General } \\
\text { Emergencyc }\end{array}$ & & $\begin{array}{l}\text { ERPG-1 or } \\
\text { equivalent }\end{array}$ & $\begin{array}{l}\text { ERPG-2 or } \\
\text { equivalent }\end{array}$ & $\begin{array}{l}\text { ERPG-3 or } \\
\text { equivalent }\end{array}$ \\
\hline \multirow{3}{*}{ Direct } & $95 \%$ worst-case & $23.7(5)$ & $0.997(20)$ & $\mathrm{NSC}^{e}$ & 1 & 3 & Site Area & 756 & 400 & 120 \\
\hline & & & & & & & & & & \\
\hline & Typical & $8.05(3)$ & $0.175(5)$ & NSC & 1 & 3 & Site Area & 300 & 175 & NSC \\
\hline
\end{tabular}

a. Protective action criteria are based on company guidelines for determining event classification. The definitions for event classifications of hazardous material releases at the INEL are discussed in the text.

b. The Alert protective action criteria value listed is the ERPG-1 value for chlorine.

c. The Site Area Emergency and General Emergency protective action criteria value listed is the ERPG-2 value for chlorine.

d. The company guidelines for ERPGs and ERPG equivalents are discussed in the text. The ERPG-3 concentration of 20 ppm for chlorine was used.

e. NSC stands for No Significant Consequences. The estimated airborne concentration was not significant at this receptor location or the ERPG (or equivalent) concentration was not exceeded at $100 \mathrm{~m}$. 
Table C-22. Summary of event consequences for a release of chlorobenzene.

\begin{tabular}{|c|c|c|c|c|c|c|c|c|c|c|}
\hline \multirow[b]{2}{*}{ Release Type } & \multirow[b]{2}{*}{$\begin{array}{l}\text { Meteorological } \\
\text { conditions }\end{array}$} & \multicolumn{3}{|c|}{$\begin{array}{c}\begin{array}{c}\text { Peak concentration (time to) } \\
(\mathrm{ppm})\end{array} \quad(\mathrm{min}) \\
\end{array}$} & \multicolumn{2}{|c|}{$\begin{array}{l}\text { Protective action criterifa } \\
\text { (ppm) }\end{array}$} & \multirow{2}{*}{$\begin{array}{l}\text { Highest } \\
\text { emergency } \\
\text { class }\end{array}$} & \multicolumn{3}{|c|}{$\begin{array}{c}\text { Distance to ERPG or equivalent } \\
(\mathrm{m})\end{array}$} \\
\hline & & $100 \mathrm{~m}$ & $756 \mathrm{~m}$ & $5,200 \mathrm{~m}$ & Aler $^{b}$ & $\begin{array}{l}\text { Site Area or General } \\
\text { Emergency }\end{array}$ & & $\begin{array}{l}\text { ERPG-1 or } \\
\text { equivalent }\end{array}$ & $\begin{array}{l}\text { ERPG-2 or } \\
\text { equivalent }\end{array}$ & $\begin{array}{l}\text { ERPG-3 or } \\
\text { equivalent }\end{array}$ \\
\hline & $95 \%$ worst-case & $7.65(5)$ & $\mathrm{NSC}^{*}$ & NSC & 30 & 50 & - & NSC & NSC & NSC \\
\hline \multicolumn{11}{|l|}{ Direct } \\
\hline & Typical & $2.32(5)$ & NSC & NSC & 30 & 50 & - & NSC & NSC & NSC \\
\hline & $95 \%$ worst-case & $13.6(4)$ & NSC & NSC & 30 & 50 & - & NSC & NSC & NSC \\
\hline \multicolumn{11}{|l|}{ Spill } \\
\hline & Typical & $1.44(2)$ & NSC & NSC & 30 & 50 & . & NSC & NSC & NSC \\
\hline & $95 \%$ worst-case & $110(5)$ & $3.72(22)$ & NSC & 30 & 50 & Site Area & 220 & 158 & NSC \\
\hline \multicolumn{11}{|l|}{ Spill w/ fire } \\
\hline & Typical & $82.5(5)$ & $2.72(7)$ & NSC & 30 & 50 & Site Area & 203 & 143 & NSC \\
\hline
\end{tabular}

a. Protective action criteria are based on company guidelines for determining event classification. The definitions for event classifications of hazardous material releases at the INEL are discussed in the text.

b. The Alert protective action criteria value listed is the ERPG-1 equivalent (3*TLV-TWA) value for chlorobenzene.

c. The Site Area Emergency and General Emergency protective action criteria value listed is the ERPG-2 equivalent (5*TLV-TWA) value for chlorobenzene.

d. The company guidelines for ERPGs and ERPG equivalents are discussed in the text. The ERPG-3 equivalent (IDLH) concentration of 2,400 ppm for chlorobenzene was used.

e. NSC stands for No Significant Consequences. The estimated airbome concentration was not significant at this receptor location or the ERPG (or equivalent) concentration was not exceeded at $100 \mathrm{~m}$. 
Table C-23. Summary of event consequences for a release of chloroform.

\begin{tabular}{|c|c|c|c|c|c|c|c|c|c|c|}
\hline \multirow[b]{2}{*}{ Release Type } & \multirow[b]{2}{*}{$\begin{array}{c}\text { Meteorological } \\
\text { conditions }\end{array}$} & \multicolumn{3}{|c|}{$\begin{array}{l}\text { Peak concentration (time to) } \\
\begin{array}{c}(\mathrm{ppm}) \\
(\mathrm{min})\end{array}\end{array}$} & \multicolumn{2}{|c|}{$\begin{array}{l}\text { Protective action criterian } \\
\qquad(\mathrm{ppm})\end{array}$} & \multirow{2}{*}{$\begin{array}{l}\text { Highest } \\
\text { emergency } \\
\text { class }\end{array}$} & \multicolumn{3}{|c|}{$\begin{array}{l}\text { Distance to ERPG or equivalent } \\
\text { (m) }\end{array}$} \\
\hline & & $100 \mathrm{~m}$ & $756 \mathrm{~m}$ & $5,200 \mathrm{~m}$ & Aler $^{b}$ & $\begin{array}{l}\text { Site Area or General } \\
\text { Emergencyc }\end{array}$ & & $\begin{array}{l}\text { ERPG-1 or } \\
\text { equivalent }\end{array}$ & $\begin{array}{l}\text { ERPG-2 or } \\
\text { equivalent }\end{array}$ & $\begin{array}{l}\text { ERPG-3 or } \\
\text { equivalent }\end{array}$ \\
\hline & $95 \%$ worst-case & $304(5)$ & $10.2(25)$ & $\mathrm{NSC}^{\mathrm{e}}$ & 100 & 1,000 & Alent & 181 & NSC & NSC \\
\hline \multicolumn{11}{|l|}{ Direct } \\
\hline & Typical & $149(3)$ & $4.49(6)$ & NSC & 100 & 1,000 & Alert & 130 & NSC & NSC \\
\hline & $95 \%$ worst-case & $60.9(5)$ & $2.72(21)$ & $\mathrm{NSC}$ & 100 & 1.000 & - & NSC & NSC & NSC \\
\hline \multicolumn{11}{|l|}{ Spill } \\
\hline & Typical & $63.9(15)$ & $1.45(25)$ & NSC & 100 & 1,000 & - & NSC & NSC & NSC \\
\hline \multirow{3}{*}{ Spill w/ fire } & $95 \%$ worst-case & $484(5)$ & $14.1(20)$ & NSC & 100 & 1,000 & Alert & 232 & NSC & $\mathrm{NSC}$ \\
\hline & & & & & & & & & & \\
\hline & Typical & $327(3)$ & $13.1(25)$ & NSC & 100 & 1,000 & Alert & 214 & NSC & $\mathrm{NSC}$ \\
\hline
\end{tabular}

a. Protective action criteria are based on company guidelines for determining event classification. The definitions for event classifications of hazardous material releases at the INFL are discussed in the text.

b. The Alert protective action criteria value listed is the draft ERPG-1 value for chloroform.

c. The Site Area Emergency and General Emergency protective action criteria value listed is the draft ERPG-2 value for chloroform.

d. The company guidelines for ERPGs and ERPG equivalents are discussed in the text. The draft ERPG-3 concentration of 5,000 ppm for chloroform was used.

e. NSC stands for No Significant Consequences. The estimated airbome concentration was not significant at this receptor location or the ERPG (or equivalent) concentration was not exceeded at $100 \mathrm{~m}$. 
Table C-24. Summary of event consequences for a release of chromium.

\begin{tabular}{|c|c|c|c|c|c|c|c|c|c|c|}
\hline \multirow[b]{2}{*}{ Release Type } & \multirow[b]{2}{*}{$\begin{array}{l}\text { Meteorological } \\
\text { conditions }\end{array}$} & \multicolumn{3}{|c|}{$\begin{array}{l}\text { Peak concentration (time to) } \\
\begin{array}{l}\left(\mathrm{mg} / \mathrm{m}^{3}\right) \\
(\mathrm{min})\end{array}\end{array}$} & \multicolumn{2}{|c|}{$\begin{array}{l}\text { Protective action criteriag } \\
\left(\mathrm{Ing} / \mathrm{m}^{3}\right)\end{array}$} & \multirow{2}{*}{$\begin{array}{l}\text { Highest } \\
\text { emergency } \\
\text { class }\end{array}$} & \multicolumn{3}{|c|}{$\begin{array}{l}\text { Distance to ERPG or equivalent }{ }^{d} \\
(\mathrm{~m})\end{array}$} \\
\hline & & $100 \mathrm{~m}$ & $756 \mathrm{~m}$ & $5,200 \mathrm{~m}$ & Alert & $\begin{array}{l}\text { Site Area or General } \\
\text { Emergency }{ }^{c}\end{array}$ & & $\begin{array}{l}\text { ERPG-1 or } \\
\text { equivalent }\end{array}$ & $\begin{array}{l}\text { ERPG-2 or } \\
\text { equivalent }\end{array}$ & $\begin{array}{l}\text { ERPG-3 or } \\
\text { equivalent }\end{array}$ \\
\hline & $95 \%$ wornt-case & $1300(2)$ & $9.1(13)$ & NSCe & 1.5 & 2.5 & Site Area & 1.600 & 1,300 & NLA $^{f}$ \\
\hline \multicolumn{11}{|l|}{ Direct } \\
\hline & Typical & $200(1)$ & $4.3(5)$ & $\mathrm{NSC}$ & 1.5 & 2.5 & Site Area & 1,400 & 1,000 & NLA \\
\hline
\end{tabular}

a. Protective action criteria are based on company guidelines for determining event classification. The definitions for event classifications of hazardous material releases at the INEL are discussed in the text.

b. The Alert protective action criteria value listed is the ERPG-1 equivalent ( $3 *$ TLV.TWA) value for chromium

c. The Site Area Emergency and General Emergency protective action criteria value listed is the ERPG-2 equivalent (5*TLV-TWA) value for chromium.

d. The company guidelines for ERPGs and ERPG equivalents are discussed in the text. There is no ERPG-3 or equivalent concentration for chromium.

e. NSC stands for No Significant Consequences. The estimated airborne concentration was not significant at this receptor location or the ERPG (or equivalent) concentration was not exceeded at $100 \mathrm{~m}$. 
Table C-25. Summary of event consequences for a release of chrysene.

\begin{tabular}{|c|c|c|c|c|c|c|c|c|c|c|}
\hline \multirow[b]{2}{*}{ Release Type } & \multirow[b]{2}{*}{$\begin{array}{c}\begin{array}{c}\text { Meteorological } \\
\text { conditions }\end{array} \\
\end{array}$} & \multicolumn{3}{|c|}{$\begin{array}{c}\begin{array}{c}\text { Peak concentration (time to) } \\
\left(\mathrm{mg}^{\prime} \mathbf{m}^{3}\right) \quad(\mathrm{min})\end{array} \\
\end{array}$} & \multicolumn{2}{|c|}{$\begin{array}{c}\text { Protective action criteria日 } \\
\left(\mathrm{mg} / \mathrm{m}^{3}\right)\end{array}$} & \multirow{2}{*}{$\begin{array}{c}\begin{array}{c}\text { Highest } \\
\text { emergency } \\
\text { class }\end{array} \\
\end{array}$} & \multicolumn{3}{|c|}{$\begin{array}{l}\text { Distance to ERPG or equivalent } \\
(\mathrm{m})\end{array}$} \\
\hline & & $100 \mathrm{~m}$ & $756 \mathrm{~m}$ & $5,200 \mathrm{~m}$ & Alert $^{b}$ & $\begin{array}{c}\text { Site Area or General } \\
\text { Emergency }{ }^{\circ}\end{array}$ & & $\begin{array}{l}\text { ERPG-1 or } \\
\text { equivalent }\end{array}$ & $\begin{array}{l}\text { ERPG-2 or } \\
\text { equivalent }\end{array}$ & $\begin{array}{l}\text { ERPG-3 or } \\
\text { equivalent }\end{array}$ \\
\hline \multirow{3}{*}{ Direct } & $95 \%$ worst-case & $25(2)$ & $0.18(13)$ & $\mathrm{NSC}^{\mathrm{e}}$ & 0.6 & 1 & Site Area & 460 & 360 & $\mathrm{NLA}^{\mathrm{f}}$ \\
\hline & & & & & & & & & & \\
\hline & Typical & $4.0(1)$ & $0.086(5)$ & NSC & 0.6 & 1 & Site Area & 260 & 200 & NLA \\
\hline
\end{tabular}

a. Protective action criteria are based on company guidelines for determining event classification. The definitions for event classifications of hazardous material releases at the INEL are discussed in the text.

b. The Alert protective action criteria value listed is the ERPG-1 equivalent (3*TLV-TWA) value for chrysene.

c. The Site Area Emergency and General Emergency protective action criteria value listed is the ERPG-2 equivalent (5*TLV-TWA) value for chrysene.

d. The company guidelines for ERPGs and ERPG equivalents are discussed in the text. There is no ERPG-3 or equivalent concentration for chrysene.

e. NSC stands for No Significant Consequences. The estinated airborne concentration was not significant at this receptor location or the ERPG (or equivalent) concentration was not exceeded at 100 m. 
Table C-26. Summary of event consequences for a release of copper.

\begin{tabular}{|c|c|c|c|c|c|c|c|c|c|c|}
\hline \multirow[b]{2}{*}{ Release Type } & \multirow[b]{2}{*}{$\begin{array}{l}\text { Meteorological } \\
\text { conditions }\end{array}$} & \multicolumn{3}{|c|}{$\begin{array}{l}\begin{array}{l}\text { Peak concentration (time to) } \\
\left(\mathrm{mg} / \mathrm{m}^{3}\right) \\
\end{array}\end{array}$} & \multicolumn{2}{|c|}{$\begin{array}{l}\text { Protective action criteriag } \\
\left(\mathbf{m g} / \mathbf{m}^{\mathbf{3}}\right)\end{array}$} & \multirow{2}{*}{$\begin{array}{c}\text { Highest } \\
\text { emergency } \\
\text { class }\end{array}$} & \multicolumn{3}{|c|}{$\begin{array}{l}\text { Distance to ERPG or equivalent } \\
(\mathrm{m})\end{array}$} \\
\hline & & $100 \mathrm{~m}$ & $756 \mathrm{~m}$ & $5,200 \mathrm{~m}$ & Alert ${ }^{b}$ & $\begin{array}{l}\text { Site Area or General } \\
\text { Emergency }{ }^{c}\end{array}$ & & $\begin{array}{l}\text { ERPG-1 or } \\
\text { equivalent }\end{array}$ & $\begin{array}{l}\text { ERPG- } 2 \text { or } \\
\text { equivalent }\end{array}$ & $\begin{array}{l}\text { ERPG-3 or } \\
\text { equivalent }\end{array}$ \\
\hline \multirow{3}{*}{ Direct } & $95 \%$ worst-case & $1300(2)$ & $9.1(13)$ & $\mathrm{NSC}^{\circ}$ & 0.6 & 1 & Site Area & 2,400 & 1,900 & NLA $^{f}$ \\
\hline & & & & & & & & & & \\
\hline & Typical & $200(1)$ & $4.3(5)$ & NSC & 0.6 & 1 & Site Area & 2,400 & 1.750 & NLA \\
\hline
\end{tabular}

a. Protective action criteria are based on company guidelines for determining event classification. The definitions for event classifications of hazardous material releases at the INEL are discussed in the text.

b. The Alert protective action criteria value listed is the ERPG-1 equivalent (3*TLV-TWA) value for copper.

c. The Site Area Emergency and General Emergency protective action criteria value listed is the ERPG-2 equivalent (5*TLV-TWA) value for copper.

d. The company guidelines for ERPGs and ERPG equivalents are discussed in the text. There is no ERPG-3 or equivalent concentration for copper.

e. NSC stands for No Significant Consequences. The estimated airborne concentration was not significant at this receptor location or the ERPG (or equivalent) concentration was not exceeded at $100 \mathrm{~m}$

f. NLA stands for No Limit Available. NLA indicates that an ERPG or equivalent concentration limit was not available for the hazardous material. 
Table C-27. Summary of event consequences for a release of cresol-p.

\begin{tabular}{|c|c|c|c|c|c|c|c|c|c|c|}
\hline \multirow[b]{2}{*}{ Release Type } & \multirow[b]{2}{*}{$\begin{array}{c}\text { Meteorological } \\
\text { conditions }\end{array}$} & \multicolumn{3}{|c|}{$\begin{array}{l}\text { Peak concentration (time to) } \\
\qquad(\mathrm{ppm}) \quad(\mathrm{min})\end{array}$} & \multicolumn{2}{|c|}{$\begin{array}{l}\text { Protective action criteria" } \\
\text { (ppm) }\end{array}$} & \multirow{2}{*}{$\begin{array}{c}\text { Highest } \\
\text { emergency } \\
\text { class }\end{array}$} & \multicolumn{3}{|c|}{$\begin{array}{l}\text { Distance to ERPG or equivalent } \\
\text { (m) }\end{array}$} \\
\hline & & $100 \mathrm{~m}$ & $756 \mathrm{~m}$ & $5,200 \mathrm{~m}$ & Alent ${ }^{b}$ & $\begin{array}{l}\text { Site Area or General } \\
\text { Emergency }^{c}\end{array}$ & & $\begin{array}{l}\text { ERPG-1 or } \\
\text { equivalent }\end{array}$ & $\begin{array}{l}\text { ERPG-2 or } \\
\text { equivalent }\end{array}$ & $\begin{array}{l}\text { ERPG-3 or } \\
\text { equivalent }\end{array}$ \\
\hline \multirow{3}{*}{ Direct } & $95 \%$ worst-case & $45.5(5)$ & $2.15(23)$ & $\mathrm{NSC}^{\mathrm{e}}$ & 15 & 25 & Site Area & 200 & 150 & NSC \\
\hline & & & & & & & & & & \\
\hline & Typical & $22.3(4)$ & $0.517(8)$ & NSC & 15 & 25 & Alert & 125 & NSC & NSC \\
\hline
\end{tabular}

a. Protective action criteria are based on company guidelines for determining event classification. The definitions for event classifications of hazardous material releases at the INEL are discussed in the text.

b. The Alert protective action criteria value listed is the ERPG-1 equivalent (3*TLV-TWA) value for cresol-p.

c. The Site Area Emergency and General Emergency protective action criteria value listed is the ERPG-2 equivalent (5*TLV-TWA) value for cresol-p.

d. The company guidelines for ERPGs and ERPG equivalents are discussed in the text. The ERPG-3 equivalent (IDLH) concentration of 250 ppm for cresol-p was used.

e. NSC stands for No Significant Consequences. The estimated airborne concentration was not significant at this receptor location or the ERPG (or equivalent) concentration was not exceeded at $100 \mathrm{~m}$. 
Table C-28. Summary of event consequences for a release of cresol.

\begin{tabular}{|c|c|c|c|c|c|c|c|c|c|c|}
\hline \multirow[b]{2}{*}{ Release Type } & \multirow[b]{2}{*}{$\begin{array}{l}\text { Meteorological } \\
\text { conditions }\end{array}$} & \multicolumn{3}{|c|}{$\begin{array}{c}\begin{array}{c}\text { Peak concentration (time to) } \\
(\mathrm{ppm})\end{array} \quad(\mathrm{min}) \\
\end{array}$} & \multicolumn{2}{|c|}{$\begin{array}{l}\text { Protective action criterian } \\
\text { (ppm) }\end{array}$} & \multirow{2}{*}{$\begin{array}{c}\text { Highest } \\
\text { emergency } \\
\text { class }\end{array}$} & \multicolumn{3}{|c|}{$\begin{array}{l}\text { Distance to ERPG or equivalent }{ }^{d} \\
(\mathrm{~m})\end{array}$} \\
\hline & & $100 \mathrm{~m}$ & $756 \mathrm{~m}$ & $5,200 \mathrm{~m}$ & Alerr $^{b}$ & $\begin{array}{l}\text { Site Area or General } \\
\text { Emergency }^{c}\end{array}$ & & $\begin{array}{l}\text { ERPG-1 or } \\
\text { equivalent }\end{array}$ & $\begin{array}{l}\text { ERPG-2 or } \\
\text { equivalent }\end{array}$ & $\begin{array}{l}\text { ERPG. } 3 \text { or } \\
\text { equivalent }\end{array}$ \\
\hline \multirow{3}{*}{ Direct } & $95 \%$ worst-case & $180(4)$ & $3.88(20)$ & $\mathrm{NSC}^{\mathrm{e}}$ & 15 & 25 & Site Area & 363 & 280 & NSC \\
\hline & & & & & & & & & & \\
\hline & Typical & $10(3)$ & $0.246(7)$ & NSC & 15 & 25 & - & NSC & NSC & NSC \\
\hline
\end{tabular}

a. Protective action criteria are based on company guidelines for determining event classification. The definitions for event classifications of hazardous material releases at the INEL are discussed in the text.

b. The Alert protective action criteria value listed is the ERPG-1 equivalent ( $3 *$ TLV-TWA) value for cresol.

c. The Site Area Emergency and General Emergency protective action criteria value listed is the ERPG-2 equivalent (5*TLV-TWA) value for cresol.

d. The company guidelines for ERPGs and ERPG equivalents are discussed in the text. The ERPG-3 equivalent (IDLH) concentration of $250 \mathrm{ppm}$ for cresol was used.

e. NSC stands for No Significant Consequences. The estimated airbome concentration was not significant at this receptor location or the ERPG (or equivalent) concentration was not exceeded at $100 \mathrm{~m}$. 
Table C-29. Summary of event consequences for a release of cresol-m.

\begin{tabular}{|c|c|c|c|c|c|c|c|c|c|c|}
\hline \multirow[b]{2}{*}{ Release Type } & \multirow[b]{2}{*}{$\begin{array}{c}\text { Meteorological } \\
\text { conditions }\end{array}$} & \multicolumn{3}{|c|}{$\begin{array}{c}\begin{array}{c}\text { Peak concentration (time to) } \\
(\mathrm{ppm}) \\
(\mathrm{min})\end{array} \\
\end{array}$} & \multicolumn{2}{|c|}{$\begin{array}{c}\text { Protective action criteria } \\
\text { (ppm) }\end{array}$} & \multirow{2}{*}{$\begin{array}{c}\begin{array}{c}\text { Highest } \\
\text { emergency } \\
\text { class }\end{array} \\
\end{array}$} & \multicolumn{3}{|c|}{$\begin{array}{l}\text { Distance to ERPG or equivalent } \\
(\mathrm{m})\end{array}$} \\
\hline & & $100 \mathrm{~m}$ & $756 \mathrm{~m}$ & $5,200 \mathrm{~m}$ & Alert & $\begin{array}{c}\text { Site Area or General } \\
\text { Emergency }\end{array}$ & & $\begin{array}{l}\text { ERPG-1 or } \\
\text { equivalent }\end{array}$ & $\begin{array}{l}\text { ERPG-2 or } \\
\text { equivalent }\end{array}$ & $\begin{array}{l}\text { ERPG-3 or } \\
\text { equivalent }\end{array}$ \\
\hline & $95 \%$ worst-case & $45.4(5)$ & $2.15(22)$ & $\mathrm{NSC}^{e}$ & 15 & 25 & Site Area & 205 & 146 & NSC \\
\hline \multicolumn{11}{|l|}{ Direct } \\
\hline & Typical & $22.4(4)$ & $0.517(6)$ & NSC & 15 & 25 & Alert & 125 & NSC & NSC \\
\hline & $95 \%$ worst-case & $0.284(10)$ & NSC & NSC & 15 & 25 & - & NSC & NSC & NSC \\
\hline \multicolumn{11}{|l|}{ Spill } \\
\hline & Typical & $0.0265(2)$ & NSC & NSC & 15 & 25 & - & NSC & NSC & NSC \\
\hline & $95 \%$ worst-case & $133(5)$ & $5.58(20)$ & NSC & 15 & 25 & Site Area & 385 & 280 & NSC \\
\hline \multicolumn{11}{|l|}{ Spill w/ fire } \\
\hline & Typical & $131(5)$ & $3.83(10)$ & NSC & 15 & 25 & Site Area & 360 & 275 & NSC \\
\hline
\end{tabular}

a. Protective action criteria are based on company guidelines for determining event classification. The definitions for event classifications of hazardous material releases at the INEL are discussed in the text.

b. The Alert protective action criteria value listed is the ERPG-1 equivalent ( 3 *TLV-TWA) value for cresol-m.

c. The Site Area Emergency and General Emergency protective action criteria value listed is the ERPG-2 equivalent (5*TLV-TWA) value for cresol-m.

d. The company guidelines for ERPGs and ERPG equivalents are discussed in the text. The ERPG-3 equivalent (IDLH) concentration of 250 ppm for cresol-m was used.

e. NSC stands for No Significant Consequences. The estimated airbome concentration was not significant at this receptor location or the ERPG (or equivalent) concentration was not exceeded at $100 \mathrm{~m}$. 
Table C-30. Summary of event consequences for a release of cresol-o (454 kg).

\begin{tabular}{l} 
Release Type $\begin{array}{l}\text { Meteorological } \\
\text { conditions }\end{array}$ \\
\cline { 2 - 5 }
\end{tabular}


Table C-31. Summary of event consequences for a release of cresol-o $(4,540 \mathrm{~kg})$.

\begin{tabular}{|c|c|c|c|c|c|c|c|c|c|c|}
\hline \multirow[b]{2}{*}{ Release Type } & \multirow[b]{2}{*}{$\begin{array}{l}\text { Meteorological } \\
\text { conditions }\end{array}$} & \multicolumn{3}{|c|}{$\begin{array}{l}\text { Peak concentration (time to) } \\
\qquad(\mathrm{ppm}) \quad(\mathrm{min})\end{array}$} & \multicolumn{2}{|c|}{$\begin{array}{l}\text { Protective action criteria } \\
\text { (ppm) }\end{array}$} & \multirow{2}{*}{$\begin{array}{l}\text { Highest } \\
\text { emergency } \\
\text { class }\end{array}$} & \multicolumn{3}{|c|}{$\begin{array}{l}\text { Distance to ERPG or equivalent } \\
\text { (m) }\end{array}$} \\
\hline & & $100 \mathrm{~m}$ & $756 \mathrm{~m}$ & $5,200 \mathrm{~m}$ & Alert $^{b}$ & $\begin{array}{l}\text { Site Area or General } \\
\text { Emergency }\end{array}$ & & $\begin{array}{l}\text { ERPG-1 or } \\
\text { equivalent }\end{array}$ & $\begin{array}{l}\text { ERPG-2 or } \\
\text { equivalent }\end{array}$ & $\begin{array}{l}\text { ERPG-3 or } \\
\text { equivalent }\end{array}$ \\
\hline & $95 \%$ worst-case & $337(5)$ & $11.3(25)$ & NSCe & 15 & 25 & Site Area & 630 & 450 & 113 \\
\hline \multicolumn{11}{|l|}{ Direct } \\
\hline & Typical & $165(3)$ & $4.92(6)$ & NSC & 15 & 25 & Site Area & 400 & 300 & $\mathrm{NSC}$ \\
\hline
\end{tabular}

a. Protective action criteria are based on company guidelines for determining event classification. The definitions for event classifications of hazardous material releases at the INEL are discussed in the text.

b. The Alert protective action criteria value listed is the ERPG- 1 equivalent (3*TLV-TWA) value for cresol-o.

c. The Site Area Emergency and General Emergency protective action criteria value listed is the ERPG-2 equivalent (5*TWA-TLV) value for cresol-o.

d. The company guidelines for ERPGs and ERPG equivalents are discussed in the text. The ERPG-3 equivalent (IDLH) concentration of 250 ppm for cresol-o was used.

e. NSC stands for No Significant Consequences. The estimated airborne concentration was not significant at this receptor location or the ERPG (or equivalent) concentration was not exceeded at $100 \mathrm{~m}$. 
Table C-32. Summary of event consequences for a release of n-dioctyphthalate.

\begin{tabular}{|c|c|c|c|c|c|c|c|c|c|c|}
\hline \multirow[b]{2}{*}{ Release Type } & \multirow[b]{2}{*}{$\begin{array}{l}\text { Meteorological } \\
\text { conditions }\end{array}$} & \multicolumn{3}{|c|}{$\begin{array}{l}\text { Peak concentration (time to) } \\
\qquad(\mathrm{ppm})\end{array}$} & \multicolumn{2}{|c|}{$\begin{array}{l}\text { Prolective action criterita } \\
\text { (ppm) }\end{array}$} & \multirow{2}{*}{$\begin{array}{c}\text { Highest } \\
\text { emergency } \\
\text { class }\end{array}$} & \multicolumn{3}{|c|}{$\begin{array}{l}\text { Distance to ERPG or equivalent } \\
\text { (m) }\end{array}$} \\
\hline & & $100 \mathrm{~m}$ & $756 \mathrm{~m}$ & $5,200 \mathrm{~m}$ & Alen ${ }^{b}$ & $\begin{array}{l}\text { Site Area or General } \\
\text { Emergencyc }\end{array}$ & & $\begin{array}{l}\text { ERPG-1 or } \\
\text { equivalent }\end{array}$ & $\begin{array}{l}\text { ERPG-2 or } \\
\text { equivalent }\end{array}$ & $\begin{array}{l}\text { ERPG-3 or } \\
\text { equivalent }\end{array}$ \\
\hline & $95 \%$ worst-case & $227(4)$ & $4.88(20)$ & NSC & 5 & 15 & Site Area & 746 & 409 & $N_{L A} f$ \\
\hline \multicolumn{11}{|l|}{ Direct } \\
\hline & Typical & $12.6(3)$ & $0.31(7)$ & NSC & 5 & 15 & Alert & 162 & NSC & NLA \\
\hline
\end{tabular}

a. Protective action criteria are basod on company guidelines for determining event classification. The definitions for event classifications of hazardous material releases at the INEL are discussed in the text.

b. The Alert protective action criteria value listed is the ERPG-1 equivalent (TLV-STEL) value for n-dioctyphthalate.

c. The Site Area Emergency and General Emergency protective action criteria value listed is the ERPG-2 equivalent (5*TLV-TWA) value for n-dioctyphthalate.

d. The company guidelines for ERPGs and ERPG equivalents are discussed in the text. There is no ERPG-3 or equivalent concentration for n-dioctyphthalate.

e. NSC stands for No Significant Consequences. The estimated airborne concentration was not significant at this receptor location or the ERPG (or equivalent) concentration was not exceeded at $100 \mathrm{~m}$

f. NLA stands for No Limit Available. NLA indicates that an ERPG or equivalent concentration limit was not available for the hazardous material. 
Table C-33. Summary of event consequences for a release of di-n-butylphthalate.

\begin{tabular}{|c|c|c|c|c|c|c|c|c|c|c|}
\hline \multirow[b]{2}{*}{ Release Type } & \multirow[b]{2}{*}{$\begin{array}{l}\text { Meteorological } \\
\text { conditions }\end{array}$} & \multicolumn{3}{|c|}{$\begin{array}{l}\text { Peak concentration (time to) } \\
\left(\mathrm{mg} / \mathrm{m}^{3}\right)\end{array}$} & \multicolumn{2}{|c|}{$\begin{array}{l}\text { Protective action criteria" } \\
\left(\mathbf{m g} / \mathbf{m}^{3}\right)\end{array}$} & \multirow{2}{*}{$\begin{array}{c}\text { Highest } \\
\text { emergency } \\
\text { class }\end{array}$} & \multicolumn{3}{|c|}{$\begin{array}{l}\text { Distance to ERPG or equivalent } \\
(\mathrm{m})\end{array}$} \\
\hline & & $100 \mathrm{~m}$ & $756 \mathrm{~m}$ & $5,200 \mathrm{~m}$ & Alert ${ }^{b}$ & $\begin{array}{l}\text { Site Area or General } \\
\text { Emergency }\end{array}$ & & $\begin{array}{l}\text { ERPG-1 or } \\
\text { equivalent }\end{array}$ & $\begin{array}{l}\text { ERPG-2 or } \\
\text { equivalent }\end{array}$ & $\begin{array}{l}\text { ERPG-3 or } \\
\text { equivalent }\end{array}$ \\
\hline & $95 \%$ worst-case & $7.2(2)$ & $0.14(13)$ & $\mathrm{NSC}^{*}$ & 15 & 25 & - & NSC & NSC & NSC \\
\hline \multicolumn{11}{|l|}{ Direct } \\
\hline & Typical & $0.44(1)$ & NSC & NSC & 15 & 25 & $\therefore$ & NSC & $\mathrm{NSC}$ & NSC \\
\hline & $95 \%$ worst-case & $0.42(2)$ & NSC & NSC & 15 & 25 & - & NSC & NSC & NSC \\
\hline \multicolumn{11}{|l|}{ Spill } \\
\hline & Typical & $0.03(1)$ & NSC & NSC & 15 & 25 & - & NSC & NSC & NSC \\
\hline & $95 \%$ worst-case & $10(2)$ & $0.3(13)$ & NSC & 15 & 25 & $\cdot$ & NSC & $\mathrm{NSC}$ & NSC \\
\hline \multicolumn{11}{|l|}{ Spill w/ fire } \\
\hline & Typical & $0.76(1)$ & NSC & NSC & 15 & 25 & - & NSC & $\mathrm{NSC}$ & NSC \\
\hline
\end{tabular}

a. Protective action criteria are based on company guidelines for determining event classification. The definitions for event classifications of hazardous material releases at the INEL are discussed in the text.

b. The Alert protective action criteria value listed is the ERPG-1 equivalent ( $3 *$ TLV-TWA) value for di-n-butylphthalate.

c. The Site Area Emergency and General Emergency protective action criteria value listed is the ERPG-2 equivalent (5*TLV-TWA) value for di-n-butylphthalate.

d. The company guidelines for ERPGs and ERPG equivalents are discussed in the text. The ERPG-3 equivalent (IDLH) concentration of $9,300 \mathrm{mg} / \mathrm{m}^{3}$ for di-n-butylphthalate was used.

e. NSC stands for No Significant Consequences. The estimated airbome concentration was not significant at this receptor location or the ERPG (or equivalent) concentration was not exceeded at $100 \mathrm{~m}$. 
Table C-34. Summary of event consequences for a release of 1,3-dichlorobenzene.

\begin{tabular}{|c|c|c|c|c|c|c|c|c|c|c|}
\hline \multirow[b]{2}{*}{ Release Type } & \multirow[b]{2}{*}{$\begin{array}{l}\text { Meteorological } \\
\text { conditions }\end{array}$} & \multicolumn{3}{|c|}{$\begin{array}{c}\begin{array}{c}\text { Peak concentration (time to) } \\
(\mathrm{ppm})\end{array} \\
\text { (min) }\end{array}$} & \multicolumn{2}{|c|}{$\begin{array}{l}\text { Protective action criteria } \\
\text { (ppm) }\end{array}$} & \multirow{2}{*}{$\begin{array}{c}\text { Highest } \\
\text { emergency } \\
\text { class }\end{array}$} & \multicolumn{3}{|c|}{$\begin{array}{l}\text { Distance to ERPG or equivalent } \\
\text { (m) }\end{array}$} \\
\hline & & $100 \mathrm{~m}$ & $756 \mathrm{~m}$ & $5,200 \mathrm{~m}$ & Alent & $\begin{array}{l}\text { Site Area or General } \\
\text { Emergency }\end{array}$ & & $\begin{array}{l}\text { ERPG-1 or } \\
\text { equivalent }\end{array}$ & $\begin{array}{l}\text { ERPG-2 or } \\
\text { equivalent }\end{array}$ & $\begin{array}{l}\text { ERPG-3 or } \\
\text { equivalent }\end{array}$ \\
\hline & $95 \%$ worst-case & $\mathrm{NSC}^{e}$ & $\mathrm{NSC}$ & NSC & 150 & 250 & - & $\mathrm{NSC}$ & NSC & $\mathrm{NLA}^{f}$ \\
\hline \multicolumn{11}{|l|}{ Direct } \\
\hline & Typical & NSC & NSC & NSC & 150 & 250 & $\therefore$ & NSC & $\mathrm{NSC}$ & NLA \\
\hline & $95 \%$ worst-case & $2.06(3)$ & $\mathrm{NSC}$ & NSC & 150 & 250 & - & NSC & NSC & NLA \\
\hline \multicolumn{11}{|l|}{ Spill } \\
\hline & Typical & $0.24(3)$ & NSC & NSC & 150 & 250 & $\ldots$ & NSC & $\mathrm{NSC}$ & NLA \\
\hline & $95 \%$ worst-case & $64.7(5)$ & NSC & NSC & 150 & 250 & . & NSC & NSC & NLA \\
\hline \multicolumn{11}{|l|}{ Spill w/ fire } \\
\hline & Typical & $60.3(5)$ & $\mathrm{NSC}$ & NSC & 150 & 250 & - & NSC & NSC & NLA \\
\hline
\end{tabular}

a. Protective action criteria are based on company guidelines for determining event classification. The definitions for event classifications of hazandous material releases at the INEL are discussed in the text.

b. The Alert protective action criteria value listed is the ERPG-1 equivalent (3*TLV-TWA) value for 1,3-dichlorobenzene.

c. The Site Area Emergency and General Emergency protective action criteria value listed is the ERPG-2 equivalent (5*TLV-TWA) value for 1,3-dichlorobenzene

d. The company guidelines for ERPGs and ERPG equivalents are discussed in the text. There is no ERPG-3 or equivalent concentration for 1,3-dichlorobenzene.

e. NSC stands for No Significant Consequences. The estimated airborne concentration was not significant at this receptor location or the ERPG (or equivalent) concentration was not exceeded at $100 \mathrm{~m}$.

f. NLA stands for No Limit Available. NLA indicates that an ERPG or equivalent concentration limit was not available for the hazardous material. 
Table C-35. Summary of event consequences for a release of dichlorobenzene-1,2 (o-dichlorobenzene).

\begin{tabular}{|c|c|c|c|c|c|c|c|c|c|c|}
\hline \multirow[b]{2}{*}{ Release Type } & \multirow[b]{2}{*}{$\begin{array}{l}\text { Meteorological } \\
\text { conditions }\end{array}$} & \multicolumn{3}{|c|}{$\begin{array}{l}\text { Peak concentration (time to) } \\
\begin{array}{c}\text { (ppm) } \quad(\min )\end{array}\end{array}$} & \multicolumn{2}{|c|}{$\begin{array}{l}\text { Protective action criterian } \\
\text { (ppm) }\end{array}$} & \multirow{2}{*}{$\begin{array}{c}\begin{array}{c}\text { Highest } \\
\text { emergency } \\
\text { class }\end{array} \\
\end{array}$} & \multicolumn{3}{|c|}{$\begin{array}{l}\text { Distance to ERPG or equivalent }{ }^{d} \\
(\mathrm{~m})\end{array}$} \\
\hline & & $100 \mathrm{~m}$ & $756 \mathrm{~m}$ & $5,200 \mathrm{~m}$ & Alert $^{b}$ & $\begin{array}{l}\text { Site Area or General } \\
\text { Emergency }^{c}\end{array}$ & & $\begin{array}{l}\text { ERPG-1 or } \\
\text { equivalent }\end{array}$ & $\begin{array}{l}\text { ERPG-2 or } \\
\text { equivalent }\end{array}$ & $\begin{array}{l}\text { ERPG-3 or } \\
\text { equivalent }\end{array}$ \\
\hline & $95 \%$ worst-case & $12(2)$ & $0.23(13)$ & $\mathrm{NSC}^{\mathrm{e}}$ & 50 & 125 & $\dot{-}$ & NSC & NSC & NSC \\
\hline \multicolumn{11}{|l|}{ Direct } \\
\hline & Typical & $0.74(1)$ & NSC & NSC & 50 & 125 & - & NSC & NSC & NSC \\
\hline \multirow{3}{*}{ Spill } & $95 \%$ worst-case & $0.55(2)$ & NSC & NSC & 50 & 125 & $\therefore$ & NSC & NSC & NSC \\
\hline & & & & & & & & & & \\
\hline & Typical & $0.04(1)$ & $\mathrm{NSC}$ & NSC & 50 & 125 & - & NSC & NSC & NSC \\
\hline \multirow{3}{*}{ Spill w/ fire } & $95 \%$ worst-case & $12(2)$ & $0.3(13)$ & NSC & 50 & 125 & - & NSC & NSC & NSC \\
\hline & & & & & & & & & & \\
\hline & Typical & $0.86(1)$ & NSC & NSC & 50 & 125 & - & NSC & NSC & NSC \\
\hline
\end{tabular}

a. Protective action criteria are based on company guidelines for determining event classification. The definitions for event classifications of hazardous material releases at the INEL are discussed in the text.

b. The Alert protective action criteria value listed is the ERPG-1 equivalent (TLV-STEL) value for o-dichlorobenzene.

c. The Site Area Emergency and General Emergency protective action criteria value listed is the ERPG-2 equivalent (5*TLV-TWA) value for o-dichlorobenzene.

d. The company guidelines for ERPGs and ERPG equivalents are discussed in the text. The ERPG-3 equivalent (IDLH) concentration of 1,000 ppm for o-dichlorobenzene was used.

e. NSC stands for No Significant Consequences. The estimated airborne concentration was not significant at this receptor location or the ERPG (or equivalent) concentration was not exceeded at $100 \mathrm{~m}$. 
Table C-36. Summary of event consequences for a release of dichlorobenzene-1,4 (p-dichlorobenzene).

\begin{tabular}{|c|c|c|c|c|c|c|c|c|c|c|}
\hline \multirow[b]{2}{*}{ Release Type } & \multirow[b]{2}{*}{$\begin{array}{l}\text { Meteorological } \\
\text { conditions }\end{array}$} & \multicolumn{3}{|c|}{$\begin{array}{l}\text { Peak concentration (time to) } \\
\left(\mathrm{mg} / \mathrm{m}^{3}\right) \quad(\mathrm{min})\end{array}$} & \multicolumn{2}{|c|}{$\begin{array}{l}\text { Protective action criteriar } \\
\left(\mathrm{mg} / \mathrm{m}^{3}\right)\end{array}$} & \multirow{2}{*}{$\begin{array}{c}\text { Highest } \\
\text { emergency } \\
\text { class }\end{array}$} & \multicolumn{3}{|c|}{$\begin{array}{c}\text { Distance to ERPG or equivalent }{ }^{d} \\
\text { (m) }\end{array}$} \\
\hline & & $100 \mathrm{~m}$ & $756 \mathrm{~m}$ & $5.200 \mathrm{~m}$ & Alert ${ }^{6}$ & $\begin{array}{l}\text { Site Area or General } \\
\text { Emergencyc }\end{array}$ & & $\begin{array}{l}\text { ERPG-1 or } \\
\text { equivalent }\end{array}$ & $\begin{array}{l}\text { ERPG-2 or } \\
\text { equivalent }\end{array}$ & $\begin{array}{l}\text { ERPG-3 or } \\
\text { equivalent }\end{array}$ \\
\hline & $95 \%$ worst-case & $25(2)$ & $0.18(13)$ & $\mathrm{NSC}^{e}$ & 660 & 2,250 & - & NSC & NSC & NSC \\
\hline \multicolumn{11}{|l|}{ Direct } \\
\hline & Typical & $4.0(1)$ & NSC & NSC & 660 & 2,250 & - & NSC & NSC & NSC \\
\hline
\end{tabular}

a. Protective action criteria are based on company guidelines for determining event classification. The definitions for event classifications of hazardous material releases at the INEL are discussed in the text.

b. The Alert protective action criteria value listed is the ERPG-1 equivalent (TLV-STEL) value for p-dichlorobenzene.

c. The Site Area Emergency and General Emergency protective action criteria value listed is the ERPG-2 equivalent (5*TLV-TWA) value for p-dichlorobenzene.

d. The company guidelines for ERPGs and ERPG equivalents are discussed in the text. The ERPG-3 equivalent (IDL $\mathrm{H}$ ) concentration of 1,000 ppm for p-dichlorobenzene was used.

e. NSC stands for No Significant Consequences. The estimated airborne concentration was not significant at this receptor location or the ERPG (or equivalent) concentration was not exceeded at $100 \mathrm{~m}$. 
Table C-37. Summary of event consequences for a release of dichlorodifluoromethane.

\begin{tabular}{|c|c|c|c|c|c|c|c|c|c|c|}
\hline \multirow[b]{2}{*}{ Release Type } & \multirow[b]{2}{*}{$\begin{array}{l}\text { Meteorological } \\
\text { conditions }\end{array}$} & \multicolumn{3}{|c|}{$\begin{array}{l}\text { Peak concentration (time to) } \\
\begin{array}{c}(\mathrm{ppm}) \\
(\mathrm{min})\end{array}\end{array}$} & \multicolumn{2}{|c|}{$\begin{array}{l}\text { Protective action criterisa } \\
\text { (ppm) }\end{array}$} & \multirow{2}{*}{$\begin{array}{c}\text { Highest } \\
\text { emergency } \\
\text { class }\end{array}$} & \multicolumn{3}{|c|}{$\begin{array}{l}\text { Distance to ERPG or equivalent } \\
(\mathrm{m})\end{array}$} \\
\hline & & $100 \mathrm{~m}$ & $756 m$ & $5,200 \mathrm{~m}$ & $\mathrm{Alert}^{\mathrm{b}}$ & $\begin{array}{l}\text { Site Area or General } \\
\text { Emergency }^{\mathrm{c}}\end{array}$ & & $\begin{array}{l}\text { ERPG-1 or } \\
\text { equivalent }\end{array}$ & $\begin{array}{l}\text { ERPG- } 2 \text { or } \\
\text { equivalent }\end{array}$ & $\begin{array}{l}\text { ERPG-3 or } \\
\text { equivalent }\end{array}$ \\
\hline \multirow{3}{*}{ Direct } & $95 \%$ worst-case & $156(5)$ & $5.98(24)$ & $\mathrm{NSC}^{\mathrm{e}}$ & 3,000 & 5,000 & - & NSC & NSC & NSC \\
\hline & & & & & & & & & & \\
\hline & Typical & $91(3)$ & NSC & NSC & 3,000 & 5,000 & - & NSC & NSC & NSC \\
\hline
\end{tabular}

a. Protective action criteria are based on company guidelines for deternining event classification. The definitions for event classifications of hazardous material releases at the INEL are discussed in the text.

b. The Alert protective action criteria value listed is the ERPG-1 equivalent ( $3 *$ TLV-TWA) value for dichlorodifluoromethane.

c. The Site Area Emergency and General Emergency protective action criteria value listed is the ERPG-2 equivalent (5*TWA-TLV) value for dichlorodifluoromethane.

d. The company guidelines for ERPGs and ERPG equivalents are discussed in the text. The ERPG-3 equivalent (IDLH) concentration of 50,000 ppm for dichlorodifluoromethanewas used.

e. NSC stands for No Significant Consequences. The estimated airborne concentration was not significant at this receptor location or the ERPG (or equivalent) concentration was not exceeded at $100 \mathrm{~m}$. 
Table C-38. Summary of event consequences for a release of 1,1-dichloroethane.

\begin{tabular}{|c|c|c|c|c|c|c|c|c|c|c|}
\hline \multirow[b]{2}{*}{ Release Type } & \multirow[b]{2}{*}{$\begin{array}{c}\text { Meteorological } \\
\text { conditions } \\
\end{array}$} & \multicolumn{3}{|c|}{$\begin{array}{l}\text { Peak concentration (time to) } \\
\begin{array}{c}(\mathrm{ppm}) \\
(\mathrm{min})\end{array}\end{array}$} & \multicolumn{2}{|c|}{$\begin{array}{l}\text { Protective action criterian } \\
\text { (ppm) }\end{array}$} & \multirow{2}{*}{$\begin{array}{c}\text { Highest } \\
\text { emergency } \\
\text { class }\end{array}$} & \multicolumn{3}{|c|}{$\begin{array}{l}\text { Distance to ERPG or equivalent }{ }^{d} \\
\text { (m) }\end{array}$} \\
\hline & & $100 \mathrm{~m}$ & $756 \mathrm{~m}$ & $5,200 \mathrm{~m}$ & Alert $^{b}$ & $\begin{array}{l}\text { Site Area or General } \\
\text { Emergency }^{c}\end{array}$ & & $\begin{array}{l}\text { ERPG-1 or } \\
\text { equivalent }\end{array}$ & $\begin{array}{l}\text { ERPG-2 or } \\
\text { equivalent }\end{array}$ & $\begin{array}{l}\text { ERPG-3 or } \\
\text { equivalent }\end{array}$ \\
\hline & $95 \%$ worst-case & $50.2(5)$ & $2.37(22)$ & $\mathrm{NSC}^{e}$ & 300 & 500 & - & NSC & NSC & NSC \\
\hline \multicolumn{11}{|l|}{ Direct } \\
\hline & Typical & $23.7(5)$ & $0.563(8)$ & NSC & 300 & 500 & - & NSC & NSC & NSC \\
\hline & $95 \%$ worst-case & $69.2(7)$ & $3.12(23)$ & NSC & 300 & 500 & - & NSC & NSC & NSC \\
\hline \multicolumn{11}{|l|}{ Spill } \\
\hline & Typical & $61.2(5)$ & $1.49(10)$ & NSC & 300 & 500 & $\therefore$ & NSC & NSC & NSC \\
\hline & $95 \%$ worst-case & $449(7)$ & $11(30)$ & NSC & 300 & 500 & Alert & 125 & NSC & NSC \\
\hline \multicolumn{11}{|l|}{ Spill w/ fire } \\
\hline & Typical & $311(4)$ & $10.9(8)$ & NSC & 300 & 500 & Alert & 105 & NSC & NSC \\
\hline
\end{tabular}

a. Protective action criteria are based on company guidelines for determining event classification. The definitions for event classifications of hazardous material releases at the INEL are discussed in the text.

b. The Alert protective action criteria value listed is the ERPG-1 equivalent (3*TLV-TWA) value for 1,1-dichloroethane.

c. The Site Area Emergency and General Emergency protective action criteria value listed is the ERPG-2 equivalent (S*TLV-TWA) value for 1,1-dichloroethane.

d. The company guidelines for ERPGs and ERPG equivalents are discussed in the text. The ERPG-3 equivalent (IDLH) concentration of 4,000 ppm for 1,1-dichloroethane was used.

e. NSC stands for No Significant Consequences. The estimated airborme concentration was not significant at this receptor location or the ERPG (or equivalent) concentration was not exceeded at $100 \mathrm{~m}$ 
Table C-39. Summary of event consequences for a release of 1,2-dichloroethane.

\begin{tabular}{|c|c|c|c|c|c|c|c|c|c|c|}
\hline \multirow[b]{2}{*}{ Release Type } & \multirow[b]{2}{*}{$\begin{array}{l}\text { Meteorological } \\
\text { conditions }\end{array}$} & \multicolumn{3}{|c|}{$\begin{array}{l}\text { Peak concentration (time to) } \\
\begin{array}{c}(\mathrm{ppm}) \quad(\mathrm{min})\end{array}\end{array}$} & \multicolumn{2}{|c|}{$\begin{array}{l}\text { Protective action criteriag } \\
\text { (ppm) }\end{array}$} & \multirow{2}{*}{$\begin{array}{l}\text { Highest } \\
\text { emergency } \\
\text { class }\end{array}$} & \multicolumn{3}{|c|}{$\begin{array}{l}\text { Distance to ERPG or equivalent } \\
\text { (m) }\end{array}$} \\
\hline & & $100 \mathrm{~m}$ & $756 \mathrm{~m}$ & $5,200 \mathrm{~m}$ & Alert ${ }^{b}$ & $\begin{array}{l}\text { Site Area or General } \\
\text { Emergencyc }\end{array}$ & & $\begin{array}{l}\text { ERPG-1 or } \\
\text { equivalent }\end{array}$ & $\begin{array}{l}\text { ERPG-2 or } \\
\text { equivalent }\end{array}$ & $\begin{array}{l}\text { ERPG-3 or } \\
\text { equivalent }\end{array}$ \\
\hline & $95 \%$ worst-case & $18(2)$ & $0.34(13)$ & NSC & 75 & 125 & - & NSC & $\mathrm{NSC}$ & NSC \\
\hline \multicolumn{11}{|l|}{ Direct } \\
\hline & Typical & $1.1(1)$ & NSC & NSC & 75 & 125 & - & NSC & $\mathrm{NSC}$ & NSC \\
\hline & $95 \%$ worst-case & $36(2)$ & $.95(13)$ & NSC & 75 & 125 & - & NSC & NSC & NSC \\
\hline \multicolumn{11}{|l|}{ Spill } \\
\hline & Typical & $2.6(1)$ & $\mathrm{NsC}$ & NSC & 75 & 125 & - & NSC & NSC & NSC \\
\hline & $95 \%$ worst-case & $300(2)$ & $7.8(13)$ & NSC & 75 & 125 & Site Area & 220 & 160 & NSC \\
\hline \multicolumn{11}{|l|}{ Spill w/ fire } \\
\hline & Typical & $21(1)$ & $0.62(5)$ & NSC & 75 & 125 & . & NSC & NSC & NSC \\
\hline
\end{tabular}

a. Protective action criteria are based on company guidelines for determining event classification. The definitions for event classifications of hazardous material releases at the INEL are discussed in the text.

b. The Alert protective action criteria value listed is the ERPG-1 equivalent (3*TLV-TWA) value for 1,2-dichloroethane.

c. The Site Area Emergency and General Emergency protective action criteria value listed is the ERPG-2 equivalent (5*TLV-TWA) value for 1,2-dichloroethane.

d. The company guidelines for ERPGs and ERPG equivalents are discussed in the text. The ERPG-3 equivalent (IDLH) concentration of 1,000 ppm for 1,2-dichloroethane was used.

e. NSC stands for No Significant Consequences. The estimated airbome concentration was not significant at this receptor location or the ERPG (or equivalent) concentration was not exceeded at $100 \mathrm{~m}$. 
Table C-40. Summary of event consequences for a release of 1,2-dichloroethene.

\begin{tabular}{|c|c|c|c|c|c|c|c|c|c|c|}
\hline \multirow[b]{2}{*}{ Release Type } & \multirow[b]{2}{*}{$\begin{array}{c}\text { Meteorological } \\
\text { conditions } \\
\end{array}$} & \multicolumn{3}{|c|}{ 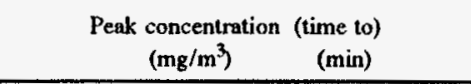 } & \multicolumn{2}{|c|}{$\begin{array}{l}\text { Protective action criteria" } \\
\left(\mathrm{mg} / \mathrm{m}^{3}\right)\end{array}$} & \multirow{2}{*}{$\begin{array}{c}\begin{array}{c}\text { Highest } \\
\text { emergency } \\
\text { class }\end{array} \\
\end{array}$} & \multicolumn{3}{|c|}{$\begin{array}{l}\text { Distance to ERPG or equivalent }{ }^{d} \\
(\mathrm{~m})\end{array}$} \\
\hline & & $100 \mathrm{~m}$ & $756 \mathrm{~m}$ & $5.200 \mathrm{~m}$ & Alerr ${ }^{b}$ & $\begin{array}{l}\text { Site Area or General } \\
\text { Emergency }^{c}\end{array}$ & & $\begin{array}{l}\text { ERPG-1 or } \\
\text { equivalent }\end{array}$ & $\begin{array}{l}\text { ERPG-2 or } \\
\text { equivalent }\end{array}$ & $\begin{array}{l}\text { ERPG-3 or } \\
\text { equivalent }\end{array}$ \\
\hline & $95 \%$ worst-case & $\mathrm{NSC}^{e}$ & NSC & NSC & 2379 & 3965 & - & NSC & NSC & NLA $^{\prime}$ \\
\hline \multicolumn{11}{|l|}{ Direct } \\
\hline & Typical & NSC & NSC & NSC & 2379 & 3965 & - & NSC & NSC & NLA \\
\hline & $95 \%$ worst-case & $378(10)$ & NSC & NSC & 2379 & 3965 & - & NSC & NSC & NLA \\
\hline \multicolumn{11}{|l|}{ Spill } \\
\hline & Typical & $346(6)$ & NSC & NSC & 2379 & 3965 & - & NSC & NSC & NLA \\
\hline \multirow{3}{*}{ Spill w/ fire } & $95 \%$ worst-case & $434(10)$ & NSC & NSC & 2379 & 3965 & - & NSC & NSC & NLA. \\
\hline & & & & & & & & & & \\
\hline & Typical & $81.9(6)$ & NSC & NSC & 2379 & 3965 & - & NSC & NSC & NLA \\
\hline
\end{tabular}

a. Protective action criteria are based on company guidelines for determining event classification. The definitions for event classifications of hazardous material releases at the INEL are discussed in the text.

b. The Alert protective action criteria value listed is the ERPG-1 equivalent (3*PEL) value for 1,2-dichloroethene.

c. The Site Area Emergency and General Emergency protective action criteria value listed is the ERPG-2 equivalent (5*PEL) value for 1,2-dichloroethene.

d. The company guidelines for ERPGs and ERPG equivalents are discussed in the text. There is no ERPG-3 or equivalent concentration for 1,2-dichloroethene.

e. NSC stands for No Significant Consequences. The estimated airborne concentration was not significant at this receptor location or the ERPG (or equivalent) concentration was not exceeded at $100 \mathrm{~m}$.

f. NLA stands for No Limit Available. NLA indicates that an ERPG or equivalent concentration limit was not available for the hazardous material. 
Table C-41. Summary of event consequences for a release of 1,1-dichloroethylene.

\begin{tabular}{|c|c|c|c|c|c|c|c|c|c|c|}
\hline \multirow[b]{2}{*}{ Release Type } & \multirow[b]{2}{*}{$\begin{array}{l}\text { Meteorological } \\
\text { conditions }\end{array}$} & \multicolumn{3}{|c|}{$\begin{array}{l}\text { Peak concentration (time to) } \\
\begin{array}{c}\text { (ppm) } \\
\text { (min) }\end{array}\end{array}$} & \multicolumn{2}{|c|}{$\begin{array}{l}\text { Protective action criterian } \\
\text { (ppm) }\end{array}$} & \multirow{2}{*}{$\begin{array}{c}\text { Highest } \\
\text { emergency } \\
\text { class } \\
\end{array}$} & \multicolumn{3}{|c|}{$\begin{array}{l}\text { Distance to ERPG or equivalend }{ }^{d} \\
(\mathrm{~m})\end{array}$} \\
\hline & & $100 \mathrm{~m}$ & $756 \mathrm{~m}$ & $5,200 \mathrm{~m}$ & $\mathrm{Aler}^{\mathrm{b}}$ & $\begin{array}{l}\text { Sile Area or General } \\
\text { Emergencyc }\end{array}$ & & $\begin{array}{l}\text { ERPG-1 or } \\
\text { equivalent }\end{array}$ & $\begin{array}{l}\text { ERPG-2 or } \\
\text { equivalent }\end{array}$ & $\begin{array}{l}\text { ERPG-3 or } \\
\text { equivalent }\end{array}$ \\
\hline & $95 \%$ worst-case & $18(2)$ & $0.35(13)$ & $\mathrm{NSC}^{e}$ & 20 & 25 & - & NSC & NSC & $\mathrm{NLA}^{\mathrm{f}}$ \\
\hline \multicolumn{11}{|l|}{ Direct } \\
\hline & Typical & $1.1(1)$ & NSC & NSC & 20 & 25 & - & NSC & NSC & NLA \\
\hline & $95 \%$ worst-case & $260(2)$ & $6.9(13)$ & $\mathrm{NSC}$ & 20 & 25 & Site Area & 410 & 360 & NLA \\
\hline \multicolumn{11}{|l|}{ Spill } \\
\hline & Typical & $19(1)$ & NSC & $\mathrm{NSC}$ & 20 & 25 & - & NSC & NSC & NLA \\
\hline & $95 \%$ worst-case & $380(2)$ & $10(13)$ & NSC & 20 & 25 & Site Area & 160 & 150 & NLA \\
\hline \multicolumn{11}{|l|}{ Spill w/ fire } \\
\hline & Typical & $28(1)$ & NSC & NSC & 20 & 25 & Site Area & 170 & 150 & NLA \\
\hline
\end{tabular}

a. Protective action criteria are based on company guidelines for determining event classification. The definitions for event classifications of hazardous material releases at the INEL are discussed in the text.

b. The Alert protective action criteria value listed is the ERPG-1 equivalent (TLV-STEL) value for 1,1-dichloroethylene.

c. The Site Area Emergency and General Emergency protective action criteria value listed is the ERPG-2 equivalent (5*TLV-TWA) value for 1,1-dichloroethylene.

d. The company guidelines for ERPGs and ERPG equivalents are discussed in the text. There is no ERPG-3 or equivalent concentration for 1,1-dichloroethylene.

e. NSC stands for No Significant Consequences. The estimated airborne concentration was not significant at this receptor location or the ERPG (or equivalent) concentration was not exceeded at $100 \mathrm{~m}$.

f. NLA stands for No Limit Available. NLA indicates that an ERPG or equivalent concentration limit was not available for the hazardous material. 
Table C-42. Summary of event consequences for a release of diethyl phthalate.

\begin{tabular}{|c|c|c|c|c|c|c|c|c|c|c|}
\hline \multirow[b]{2}{*}{ Release Type } & \multirow[b]{2}{*}{$\begin{array}{l}\text { Meteorological } \\
\text { conditions }\end{array}$} & \multicolumn{3}{|c|}{$\begin{array}{cc}\begin{array}{c}\text { Peak concentration (time to }) \\
\left(\mathrm{mg} / \mathrm{m}^{3}\right)\end{array} & (\mathrm{min}) \\
\end{array}$} & \multicolumn{2}{|c|}{$\begin{array}{c}\text { Protective action criteriaa } \\
\left(\mathbf{m g} / \mathbf{m}^{3}\right)\end{array}$} & \multirow{2}{*}{$\begin{array}{c}\text { Highest } \\
\text { emergency } \\
\text { class }\end{array}$} & \multicolumn{3}{|c|}{$\begin{array}{l}\text { Distance to ERPG or equivalent }{ }^{d} \\
\text { (m) }\end{array}$} \\
\hline & & $100 \mathrm{~m}$ & $756 \mathrm{~m}$ & $5,200 \mathrm{~m}$ & Alent $^{b}$ & $\begin{array}{l}\text { Site Area or General } \\
\text { Emergency }^{c}\end{array}$ & & $\begin{array}{l}\text { ERPG-1 or } \\
\text { equivalent }\end{array}$ & $\begin{array}{l}\text { ERPG-2 or } \\
\text { equivalent }\end{array}$ & $\begin{array}{l}\text { ERPG-3 or } \\
\text { equivalent }\end{array}$ \\
\hline & $95 \%$ worst-case & $720(2)$ & $14(13)$ & $0.62(87)$ & 15 & 25 & Site Area & 720 & 550 & $\mathrm{NLA}^{\mathrm{f}}$ \\
\hline \multicolumn{11}{|l|}{ Direct } \\
\hline & Typical & $44(1)$ & $1.1(5)$ & $\mathrm{NSC}^{\mathrm{e}}$ & 15 & 25 & Site Area & 170 & 140 & NLA \\
\hline & $95 \%$ worst-case & 2.2E-3 (2) & NSC & NSC & 15 & 25 & - & $\mathrm{NSC}$ & NSC & NLA \\
\hline \multicolumn{11}{|l|}{ Spill } \\
\hline & Typical & $1.6 \mathrm{E}-4(1)$ & NSC & NSC & 15 & 25 & - & NSC & NSC & NSC \\
\hline & $95 \%$ worst-case & $0.47(2)$ & NSC & NSC & 15 & 25 & - & NSC & NSC & NLA \\
\hline \multicolumn{11}{|l|}{ Spill w/ fire } \\
\hline & Typical & $0.034(1)$ & NSC & NSC & 15 & 25 & - & NSC & NSC & NLA \\
\hline
\end{tabular}

a. Protective action criteria are based on company guidelines for determining event classification. The definitions for event classifications of hazardous material releases at the INEL are discussed in the text.

b. The Alert protective action criteria value listed is the ERPG-I equivalent (3*TLV-TWA) value for diethyl phthalate.

c. The Site Area Emergency and General Emergency protective action criteria value listed is the ERPG-2 equivalent (5*TLV-TWA) value for diethyl phthalate.

d. The company guidelines for ERPGs and ERPG equivalents are discussed in the text. There is no ERPG-3 or equivalent concentration for diethyl phthalate.

e. NSC stands for No Significant Consequences. The estimated airborne concentration was not significant at this receptor location or the ERPG (or equivalent) concentration was not exceeded at $100 \mathrm{~m}$.

f. NLA stands for No Limit Available. NLA indicates that an ERPG or equivalent concentration limit was not available for the hazardous material. 
Table C-43. Summary of event consequences for a release of 2,4-dinitrotoluene.

\begin{tabular}{|c|c|c|c|c|c|c|c|c|c|c|}
\hline \multirow[b]{2}{*}{ Release Type } & \multirow[b]{2}{*}{$\begin{array}{l}\text { Meteorological } \\
\text { conditions }\end{array}$} & \multicolumn{3}{|c|}{$\begin{array}{l}\begin{array}{l}\text { Peak concentration (time to) } \\
\left(\mathrm{mg} / \mathrm{m}^{3}\right)\end{array} \quad(\mathrm{min}) \\
\end{array}$} & \multicolumn{2}{|c|}{$\begin{array}{l}\text { Protective action criteriag } \\
\text { (ppm) }\end{array}$} & \multirow{2}{*}{$\begin{array}{c}\begin{array}{c}\text { Highest } \\
\text { emergency } \\
\text { class }\end{array} \\
\end{array}$} & \multicolumn{3}{|c|}{$\begin{array}{l}\text { Distance to ERPG or equivalent }{ }^{d} \\
(\mathrm{~m})\end{array}$} \\
\hline & & $100 \mathrm{~m}$ & $756 \mathrm{~m}$ & $5,200 \mathrm{~m}$ & Alert & $\begin{array}{l}\text { Site Area or General } \\
\text { Emergency }{ }^{\mathbf{c}}\end{array}$ & & $\begin{array}{l}\text { ERPG-1 or } \\
\text { equivalent }\end{array}$ & $\begin{array}{l}\text { ERPG-2 or } \\
\text { equivalent }\end{array}$ & $\begin{array}{l}\text { ERPG } 3 \text { or } \\
\text { equivalent }\end{array}$ \\
\hline \multirow{3}{*}{ Direct } & $95 \%$ worst-case & $2.5(2)$ & $0.018(13)$ & $\mathrm{NSC}^{e}$ & 0.45 & 0.75 & Site Area & 200 & 160 & NSC \\
\hline & & & & & & & & & & \\
\hline & Typical & $0.4(1)$ & $8.6 \mathrm{E}-3(5)$ & NSC & 0.45 & 0.75 & $\cdot$ & NSC & NSC & NSC \\
\hline
\end{tabular}

a. Protective action criteria are based on company guidelines for determining event classification. The definitions for event classifications of hazardous material releases at the INEL are discussed in the text.

b. The Alert protective action criteria value listed is the ERPG-1 equivalent (3*TLV-TWA) value for 2,4-dinitrotoluene.

c. The Site Area Emergency and General Emergency protective action criteria value listed is the ERPG-2 equivalent (5*TLV-TWA) value for 2,4-dinitrotoluene.

d. The company guidelines for ERPGs and ERPG equivalents are discussed in the text. The ERPG-3 equivalent (IDLH) concentration of $200 \mathrm{mg} / \mathrm{m}^{3}$ for $2,4-$ dinitrotoluene was used.

e. NSC stands for No Significant Consequences. The estimated airborne concentration was not significant at this receptor location or the ERPG (or equivalent) concentration was not exceeded at $100 \mathrm{~m}$. 
Table C-44. Summary of event consequences for a release of endrin $(227 \mathrm{~kg})$.

\begin{tabular}{|c|c|c|c|c|c|c|c|c|c|c|}
\hline \multirow[b]{2}{*}{ Release Type } & \multirow[b]{2}{*}{$\begin{array}{l}\text { Meteorological } \\
\text { conditions }\end{array}$} & \multicolumn{3}{|c|}{$\begin{array}{c}\begin{array}{c}\text { Peak concentration (time to) } \\
\left(\mathrm{mg} / \mathrm{m}^{3}\right)\end{array} \quad(\mathrm{min}) \\
\end{array}$} & \multicolumn{2}{|c|}{$\begin{array}{c}\text { Protective action criteriag } \\
\left(\mathrm{mg}^{\mathrm{a}} / \mathrm{m}^{3}\right)\end{array}$} & \multirow{2}{*}{$\begin{array}{c}\text { Highest } \\
\text { emergency } \\
\text { class }\end{array}$} & \multicolumn{3}{|c|}{$\begin{array}{c}\text { Distance to ERPG or equivalent } \\
(\mathrm{m})\end{array}$} \\
\hline & & $100 \mathrm{~m}$ & $756 \mathrm{~m}$ & $5,200 \mathrm{~m}$ & Alert $^{b}$ & $\begin{array}{l}\text { Site Aren or General } \\
\text { Emergency }\end{array}$ & & $\begin{array}{l}\text { ERPG-1 or } \\
\text { equivalent }\end{array}$ & $\begin{array}{l}\text { ERPG-2 or } \\
\text { equivalent }\end{array}$ & $\begin{array}{l}\text { ERPG-3 or } \\
\text { equivalent }\end{array}$ \\
\hline \multirow{3}{*}{ Direct } & $95 \%$ worst-case & $130(2)$ & $0.91(13)$ & $\mathrm{NSC}^{\mathrm{e}}$ & 0.3 & 0.5 & Site Area & 1,200 & 975 & NSC \\
\hline & & & & & & & & & & \\
\hline & Typical & $20(1)$ & $0.43(5)$ & NSC & 0.3 & 0.5 & Site Area & 920 & 700 & NSC \\
\hline
\end{tabular}

a. Protective action criteria are based on company guidelines for determining event classification. The definitions for event classifications of hazardous material releases at the INEL are discussed in the text:

b. The Alert protective action criteria value listed is the ERPG-1 equivalent (3*TLV-TWA) value for endrin.

c. The Site Area Emergency and General Emergency protective action criteria value listed is the ERPG-2 equivalent (5*TLV-TWA) value for endrin.

d. The company guidelines for ERPGs and ERPG equivalents are discussed in the text. The ERPG-3 equivalent (IDLH) concentration of $200 \mathrm{mg} / \mathrm{m}^{3}$ for endrin was used.

e. NSC stands for No Significant Consequences. The estimated airborne concentration was not significant at this receptor location or the ERPG (or equivalent) concentration was not exceeded at $100 \mathrm{~m}$. 
Table C-45. Summary of event consequences for a release of endrin $(4,540 \mathrm{~kg})$.

\begin{tabular}{|c|c|c|c|c|c|c|c|c|c|c|}
\hline \multirow[b]{2}{*}{ Release Type } & \multirow[b]{2}{*}{$\begin{array}{l}\text { Meteorological } \\
\text { conditions }\end{array}$} & \multicolumn{3}{|c|}{$\begin{array}{l}\text { Peak concentration (time to }) \\
\left(\mathrm{mg} / \mathrm{m}^{3}\right) \quad(\mathrm{min})\end{array}$} & \multicolumn{2}{|c|}{$\begin{array}{l}\text { Protective action criteriag } \\
\qquad\left(\mathrm{mg} / \mathrm{m}^{3}\right)\end{array}$} & \multirow{2}{*}{$\begin{array}{c}\begin{array}{c}\text { Highest } \\
\text { emergency } \\
\text { class }\end{array} \\
\end{array}$} & \multicolumn{3}{|c|}{$\begin{array}{l}\text { Distance to ERPG or equivalent }{ }^{d} \\
\qquad(\mathrm{~m})\end{array}$} \\
\hline & & $100 \mathrm{~m}$ & $756 \mathrm{~m}$ & $5,200 \mathrm{~m}$ & Alert $^{b}$ & $\begin{array}{l}\text { Site Area or General } \\
\text { Emergency }\end{array}$ & & $\begin{array}{l}\text { ERPG-1 or } \\
\text { equivalent }\end{array}$ & $\begin{array}{l}\text { ERPG-2 or } \\
\text { equivalent }\end{array}$ & $\begin{array}{l}\text { ERPG-3 or } \\
\text { equivalent }\end{array}$ \\
\hline \multirow{3}{*}{ Direct } & $95 \%$ worst-case & $2,500(2)$ & $18(13)$ & $0.18(87)$ & 0.3 & 0.5 & Site Area & 4,200 & 3,400 & 280 \\
\hline & & & & & & & & & & \\
\hline & Typical & $400(1)$ & $8.6(5)$ & $0.35(35)$ & 0.3 & 0.5 & Site Area & 5,800 & 4,100 & 150 \\
\hline
\end{tabular}

a. Protective action criteria are based on company guidelines for determining event classification. The definitions for event classifications of hazardous material releases at the INEL are discussed in the text.

b. The Alert protective action criteria value listed is the ERPG-1 equivalent ( $3 *$ TLV-TWA) value for endrin.

c. The Site Area Emergency and General Emergency protective action criteria value listed is the ERPG-2 equivalent (5*TLV.TWA) value for endrin.

d. The company guidelines for ERPGs and ERPG equivalents are discussed in the text. The ERPG-3 equivalent (IDLH) concentration of $200 \mathrm{mg} / \mathrm{m}^{3}$ for endrin was used.

e. NSC stands for No Significant Consequences. The estimated airborne concentration was not significant at this receptor location or the ERPG (or equivalent) concentration was not exceeded at $100 \mathrm{~m}$. 
Table C-46. Summary of event consequences for a release of ethyl benzene.

\begin{tabular}{|c|c|c|c|c|c|c|c|c|c|c|}
\hline \multirow[b]{2}{*}{ Release Type } & \multirow[b]{2}{*}{$\begin{array}{c}\text { Meteorological } \\
\text { conditions }\end{array}$} & \multicolumn{3}{|c|}{$\begin{array}{l}\begin{array}{l}\text { Peak concentration (time to) } \\
\text { (ppm) } \quad(\mathrm{min})\end{array} \\
\end{array}$} & \multicolumn{2}{|c|}{$\begin{array}{l}\text { Protective action criterisa } \\
\text { (ppm) }\end{array}$} & \multirow{2}{*}{$\begin{array}{c}\text { Highest } \\
\text { emergency } \\
\text { class } \\
\end{array}$} & \multicolumn{3}{|c|}{$\begin{array}{l}\text { Distance to ERPG or equivalent }{ }^{\text {d }} \\
(\mathrm{m})\end{array}$} \\
\hline & & $100 \mathrm{~m}$ & $756 \mathrm{~m}$ & $5,200 \mathrm{~m}$ & Alert ${ }^{b}$ & $\begin{array}{l}\text { Sile Area or General } \\
\text { Emergencyc }\end{array}$ & & $\begin{array}{l}\text { ERPG-1 or } \\
\text { equivalent }\end{array}$ & $\begin{array}{l}\text { ERPG- } 2 \text { or } \\
\text { equivalent }\end{array}$ & $\begin{array}{l}\text { ERPG-3 or } \\
\text { equivalent }\end{array}$ \\
\hline & $95 \%$ worst-case & $46.4(5)$ & $2.19(23)$ & $\mathrm{NSC}^{\mathrm{e}}$ & 125 & 500 & - & NSC & NSC & NSC \\
\hline \multicolumn{11}{|l|}{ Direct } \\
\hline & Typical & $22.6(3)$ & $0.526(8)$ & NSC & 125 & 500 & - & NSC & NSC & NSC \\
\hline & $95 \%$ worst-case & $12.7(5)$ & $0.281(21)$ & $\mathrm{NSC}$ & 125 & 500 & - & NSC & $\mathrm{NSC}$ & NSC \\
\hline \multicolumn{11}{|l|}{ Spill } \\
\hline & Typical & $1.24(2)$ & NSC & NSC & 125 & 500 & $\therefore$ & NSC & NSC & NSC \\
\hline \multirow{3}{*}{ Spill w/ fire } & $95 \%$ worst-case & $6.58(5)$ & $0.375(23)$ & NSC & 125 & 500 & - & NSC & NSC & NSC \\
\hline & & & & 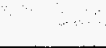 & & & & & & \\
\hline & Typical & $13.9(3)$ & $0.345(10)$ & NSC & 125 & 500 & - & NSC & NSC & $\mathrm{NSC}$ \\
\hline
\end{tabular}

a. Protective action criteria are based on company guidelines for determining event classification. The definitions for event classifications of hazardous material releases at the INEL are discussed in the text.

b. The Alert protective action criteria value listed is the ERPG-1 equivalent (TLV-STEL) value for ethyl benzene.

c. The Site Area Emergency and General Emergency protective action criteria value listed is the ERPG-2 equivalent (5*TLV-TWA) value for ethyl benzene.

d. The company guidelines for ERPGs and ERPG equivalents are discussed in the text. The ERPG-3 equivalent (IDLH) concentration of 2,000 ppm for ethyl benzene was used.

e. NSC stands for No Significant Consequences. The estimated airbome concentration was not significant at this receptor location or the ERPG (or equivalent) concentration was not exceeded at $100 \mathrm{~m}$. 
Table C-47. Summary of event consequences for a release of ethylenediamine.

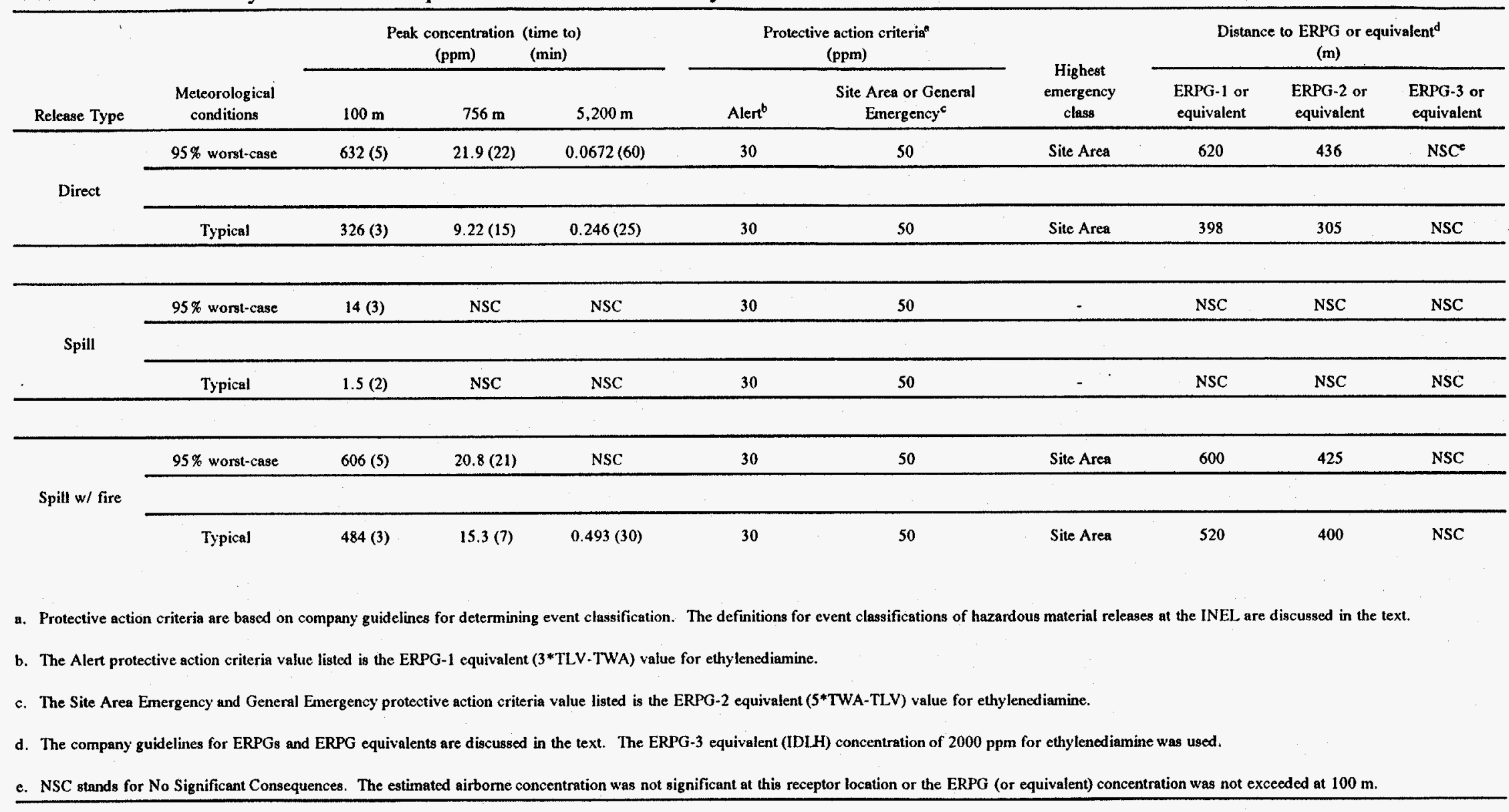


Table C-48. Summary of event consequences for a release of ethylene diamine tetraacetic acid.

\begin{tabular}{|c|c|c|c|c|c|c|c|c|c|c|}
\hline \multirow[b]{2}{*}{ Release Type } & \multirow[b]{2}{*}{$\begin{array}{l}\text { Meteorological } \\
\text { conditions }\end{array}$} & \multicolumn{3}{|c|}{ 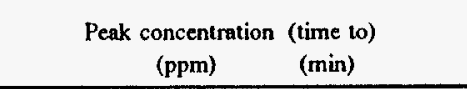 } & \multicolumn{2}{|c|}{$\begin{array}{c}\text { Protective action criterian } \\
\text { (ppm) }\end{array}$} & \multirow{2}{*}{$\begin{array}{l}\text { Highest } \\
\text { emergency } \\
\text { class }\end{array}$} & \multicolumn{3}{|c|}{$\begin{array}{l}\text { Distance to ERPG or equivalent } \\
\text { (m) }\end{array}$} \\
\hline & & $100 \mathrm{~m}$ & $756 \mathrm{~m}$ & $5,200 \mathrm{~m}$ & Alert ${ }^{b}$ & $\begin{array}{l}\text { Site Area or General } \\
\text { Emergency }\end{array}$ & & $\begin{array}{l}\text { ERPG- } 1 \text { or } \\
\text { equivalent }\end{array}$ & $\begin{array}{l}\text { ERPG-2 or } \\
\text { equivalent }\end{array}$ & $\begin{array}{l}\text { ERPG-3 or } \\
\text { equivalent }\end{array}$ \\
\hline \multirow{3}{*}{ Direct } & $95 \%$ worst-case & $334(4)$ & $7.18(20)$ & $\mathrm{NSC}^{e}$ & 30 & 50 & Site Area & 348 & 266 & $\mathrm{NLA}^{\mathrm{f}}$ \\
\hline & & & & & & & & & & \\
\hline & Typical & $18.5(2)$ & NSC & NSC & 30 & 50 & - & NSC & NSC & NLA \\
\hline
\end{tabular}

a. Protective action criteria are based on company guidelines for determining event classification. The definitions for event classifications of hazardous material releases at the INEL, are discussed in the text.

b. The Alert protective action criteria value listed is the ERPG-1 equivalent (estimated by WERF IH) value for ethylene diamine tetraacetic acid.

c. The Site Area Emergency and General Emergency protective action criteria value listed is the ERPG-2 equivalent (estimated by WERF IH) value for ethylene diamine tetraacetic acid.

d. The company guidelines for ERPGs and ERPG equivalents are discussed in the text. There is no ERPG-3 or equivalent concentration for ethylene diamine tetraacetic acid

e. NSC stands for No Significant Consequences. The estimated airborne concentration was not significant at this receptor location or the ERPG (or equivalent) concentration was not exceeded at $100 \mathrm{~m}$.

f. NLA stands for No Limit Available. NLA indicates that an ERPG or equivalent concentration limit was not available for the hazandous material. 
Table C-49. Summary of event consequences for a release of fluoranthene.

\begin{tabular}{|c|c|c|c|c|c|c|c|c|c|c|}
\hline \multirow[b]{2}{*}{ Release Type } & \multirow[b]{2}{*}{$\begin{array}{l}\text { Meteorological } \\
\text { conditions }\end{array}$} & \multicolumn{3}{|c|}{$\begin{array}{c}\begin{array}{c}\text { Peak concentration (time to) } \\
(\mathrm{ppm})\end{array} \quad(\mathrm{min}) \\
\end{array}$} & \multicolumn{2}{|c|}{$\begin{array}{c}\begin{array}{c}\text { Protective action criteria } \\
\text { (ppm) }\end{array} \\
\end{array}$} & \multirow{2}{*}{$\begin{array}{l}\text { Highest } \\
\text { emergency } \\
\text { class }\end{array}$} & \multicolumn{3}{|c|}{$\begin{array}{l}\text { Distance to ERPG or equivalent } \\
\qquad(\mathrm{m})\end{array}$} \\
\hline & & $100 \mathrm{~m}$ & $756 \mathrm{~m}$ & $5,200 \mathrm{~m}$ & Alerr $^{b}$ & $\begin{array}{l}\text { Site Area or General } \\
\text { Emergency } \\
\end{array}$ & & $\begin{array}{l}\text { ERPG-1 or } \\
\text { equivalent }\end{array}$ & $\begin{array}{l}\text { ERPG-2 or } \\
\text { equivalent }\end{array}$ & $\begin{array}{l}\text { ERPG-3 or } \\
\text { equivalent }\end{array}$ \\
\hline \multirow{3}{*}{ Direct } & $95 \%$ worst-case & $3.9(5)$ & $\mathrm{NSC}^{\mathrm{e}}$ & NSC & 30 & 50 & - & NSC & NSC & $\mathrm{NLA}^{f}$ \\
\hline & & & & & & & & & & \\
\hline & Typical & $1.22(4)$ & NSC & NSC & 30 & 50 & - & NSC & NSC & NLA \\
\hline
\end{tabular}

a. Protective action criteria are based on company guidelines for determining event classification. The definitions for event classifications of hazardous material releases at the INEL are discussed in the text.

b. The Alert protective action criteria value listed is the ERPG-1 equivalent (estimated by WERF IH) value for fluoranthene.

c. The Site Area Emergency and General Emergency protective action criteria value listed is the ERPG-2 equivalent (estimatod by WERF IH) value for fluoranthene.

d. The company guidelines for ERPGs and ERPG equivalents are discussed in the text. There is no ERPG-3 or equivalent concentration for fluoranthene.

e. NSC stands for No Significant Consequences. The estimated airborne concentration was not significant at this receptor location or the ERPG (or equivalent) concentration was not exceeded at $100 \mathrm{~m}$. 
Table C-50. Summary of event consequences for a release of formic acid.

\begin{tabular}{|c|c|c|c|c|c|c|c|c|c|c|}
\hline \multirow[b]{2}{*}{ Release Type } & \multirow[b]{2}{*}{$\begin{array}{l}\text { Meteorological } \\
\text { conditions }\end{array}$} & \multicolumn{3}{|c|}{$\begin{array}{l}\text { Peak concentration (time to) } \\
\begin{array}{c}(\mathrm{ppm}) \\
(\mathrm{min})\end{array}\end{array}$} & \multicolumn{2}{|c|}{$\begin{array}{l}\text { Protective action criteria" } \\
\text { (ppm) }\end{array}$} & \multirow{2}{*}{$\begin{array}{l}\text { Highest } \\
\text { emergency } \\
\text { class }\end{array}$} & \multicolumn{3}{|c|}{$\begin{array}{l}\text { Distance to ERPG or equivalent } \\
\qquad(\mathrm{m})\end{array}$} \\
\hline & & $100 \mathrm{~m}$ & $756 \mathrm{~m}$ & $5,200 \mathrm{~m}$ & Aler $^{b}$ & $\begin{array}{l}\text { Site Area or General } \\
\text { Emergency }^{c}\end{array}$ & & $\begin{array}{l}\text { ERPG-1 or } \\
\text { equivalent }\end{array}$ & $\begin{array}{l}\text { ERPG-2 or } \\
\text { equivalent }\end{array}$ & $\begin{array}{l}\text { ERPG-3 or } \\
\text { equivalent }\end{array}$ \\
\hline & $95 \%$ worst-case & $456(4)$ & $\mathrm{NSC}^{e}$ & $0.286(60)$ & 10 & 25 & Site Area & 1,100 & 603 & 530 \\
\hline \multicolumn{11}{|l|}{ Direct } \\
\hline & Typical & $260(3)$ & $6.08(6)$ & NSC & 10 & 25 & Site Area & 573 & 351 & 317 \\
\hline & $95 \%$ worst-case & $33(3)$ & $0.741(18)$ & $\mathrm{NSC}$ & 10 & 25 & Site Area & 187 & 116 & NSC \\
\hline \multicolumn{11}{|l|}{ Spill } \\
\hline & Typical & $3.5(1)$ & NSC & $\mathrm{NSC}$ & 10 & 25 & - & NSC & NSC & NSC \\
\hline & $95 \%$ worst-case & $550(5)$ & $22(22)$ & $\mathrm{NSC}$ & 10 & 25 & Site Area & 1,200 & 680 & 598 \\
\hline \multicolumn{11}{|l|}{ Spill w/ fire } \\
\hline & Typical & $557(3)$ & $10.7(7)$ & NSC & 10 & 25 & Site Area & 756 & 483 & 437 \\
\hline
\end{tabular}

a. Protective action criteria are based on company guidelines for determining event classification. The definitions for event classifications of hazardous material releases at the INEL are discussed in the text.

b. The Alert protective action criteria value listed is the ERPG-1 equivalent (TLV-STEL) value for formic acid.

c. The Site Area Emergency and General Emergency protective action criteria value listed is the ERPG-2 equivalent (5*TWA-TLV) value for formic acid.

d. The company guidelines for ERPGs and ERPG equivalents are discussed in the text. The ERPG-3 equivalent (IDLH) concentration of 30 ppm for formic acid was used.

e. NSC stands for No Significant Consequences. The estimated airbome concentration was not significant at this receptor location or the ERPG (or equivalent) concentration was not exceeded at $100 \mathrm{~m}$. 


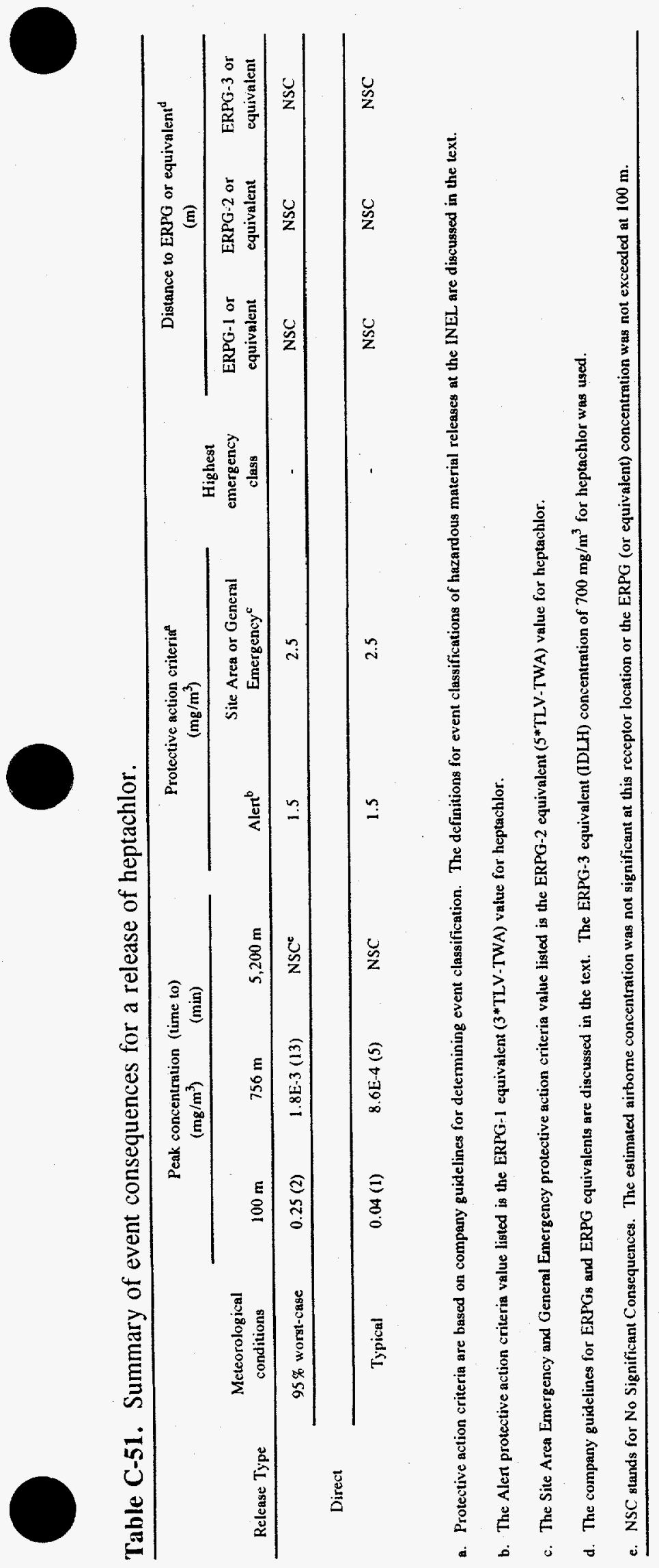


Table C-52. Summary of event consequences for a release of hexachlorobenzene.

\begin{tabular}{|c|c|c|c|c|c|c|c|c|c|c|}
\hline \multirow[b]{2}{*}{ Release Type } & \multirow[b]{2}{*}{$\begin{array}{c}\text { Meteorological } \\
\text { conditions } \\
\end{array}$} & \multicolumn{3}{|c|}{$\begin{array}{l}\text { Peak concentration (time to) } \\
\begin{array}{c}(\mathrm{ppm}) \\
(\mathrm{min})\end{array}\end{array}$} & \multicolumn{2}{|c|}{$\begin{array}{l}\text { Protective action criteria } \\
\text { (ppm) }\end{array}$} & \multirow{2}{*}{$\begin{array}{c}\text { Highest } \\
\text { emergency } \\
\text { class }\end{array}$} & \multicolumn{3}{|c|}{$\begin{array}{l}\text { Distance to ERPG or equivalent }{ }^{d} \\
\text { (m) }\end{array}$} \\
\hline & & $100 \mathrm{~m}$ & $756 \mathrm{~m}$ & $5,200 \mathrm{~m}$ & Alert & $\begin{array}{l}\text { Site Area or General } \\
\text { Energencyc }\end{array}$ & & $\begin{array}{l}\text { ERPG-1 or } \\
\text { equivalent }\end{array}$ & $\begin{array}{l}\text { ERPG-2 or } \\
\text { equivalent }\end{array}$ & $\begin{array}{l}\text { ERPG-3 or } \\
\text { equivalent }\end{array}$ \\
\hline \multirow{3}{*}{ Direct } & $95 \%$ worst-case & $0.56(6)$ & $\mathrm{NSC}^{\mathrm{e}}$ & NSC & 3 & 5 & - & NSC & NSC & NI.Af \\
\hline & & & & & & & & & & \\
\hline & Typical & NSC & NSC & NSC & 3 & 5 & . & NSC & NSC & NLA \\
\hline
\end{tabular}

a. Protective action criteria are based on company guidelines for determining event classification. The definitions for event classifications of hazardous material releases at the INEL are discussed in the text.

b. The Alen protective action criteria value listed is the ERPG-1 equivalent ( $3 *$ TLV-TWA) value for hexachlorobenzene.

c. The Site Area Emergency and General Emergency protective action criteria value listed is the ERPG-2 equivalent (5*TLV-TWA) value for hexachlorobenzene.

d. The company guidelines for ERPGis and ERPG equivalents are discussed in the text. There is no ERPG-3 or equivalent concentration for hexachlorobenzene.

e. NSC stands for No Significant Consequences. The estimated airborne concentration was not significant at this receptor location or the ERPG (or equivalent) concentration was not exceeded at $100 \mathrm{~m}$.

f. NLA stands for No Limit Available. NLA indicates that an ERPG or equivalent concentration limit was not available for the hazardous material. 
Table C-53. Summary of event consequences for a release of hexachlorobutadiene.

\begin{tabular}{|c|c|c|c|c|c|c|c|c|c|c|}
\hline \multirow[b]{2}{*}{ Release Type } & \multirow[b]{2}{*}{$\begin{array}{l}\text { Meteorological } \\
\text { conditions }\end{array}$} & \multicolumn{3}{|c|}{$\begin{array}{l}\text { Peak concentration (time to) } \\
\qquad(\mathrm{ppm}) \quad(\mathrm{min})\end{array}$} & \multicolumn{2}{|c|}{$\begin{array}{l}\text { Protective action criteriaa } \\
\text { (ppm) }\end{array}$} & \multirow{2}{*}{$\begin{array}{c}\text { Highest } \\
\text { emergency } \\
\text { class }\end{array}$} & \multicolumn{3}{|c|}{$\begin{array}{l}\text { Distance to ERPG or equivalent } \\
\text { (m) }\end{array}$} \\
\hline & & $100 \mathrm{~m}$ & $756 \mathrm{~m}$ & $5,200 \mathrm{~m}$ & Alert ${ }^{b}$ & $\begin{array}{l}\text { Site Area or General } \\
\text { Emergencyc }\end{array}$ & & $\begin{array}{l}\text { ERPG-1 or } \\
\text { equivalent }\end{array}$ & $\begin{array}{l}\text { ERPG-2 or } \\
\text { equivalent }\end{array}$ & $\begin{array}{l}\text { ERPG-3 or } \\
\text { equivalent }\end{array}$ \\
\hline & $95 \%$ worst-case & $0.068(2)$ & $\mathrm{NSC}^{\mathrm{e}}$ & NSC & 3 & 10 & - & NSC & $\mathrm{NSC}$ & NSC \\
\hline \multicolumn{11}{|l|}{ Direct } \\
\hline & Typical & 4.2E-3 (1) & $\mathrm{NSC}$ & NSC & 3 & 10 & - & NSC & $\mathrm{NSC}$ & NSC \\
\hline & $95 \%$ worst-case & $2.4 \mathrm{E}-3(2)$ & NSC & NSC & 3 & 10 & - & $\mathrm{NSC}$ & NSC & $\mathrm{NSC}$ \\
\hline \multicolumn{11}{|l|}{ Spill } \\
\hline & Typical & $1.5 \mathrm{E}-4(1)$ & $\mathrm{NSC}$ & NSC & 3 & 10 & - & NSC & NSC & NSC \\
\hline \multirow{3}{*}{ Spill w/ fire } & $95 \%$ worst-case & $0.1(2)$ & NSC & NSC & 3 & 10 & . & NSC & NSC & NSC \\
\hline & & & & & & & & & & \\
\hline & Typical & $6.3 \mathrm{E}-3(1)$ & NSC & NSC & 3 & 10 & - & NSC & NSC & $\mathrm{NSC}$ \\
\hline
\end{tabular}

a. Protective action criteria are based on company guidelines for detenmining event classification. The definitions for event classifications of hazardous material releases at the INEL are discussed in the text.

b. The Alert protective action criteria value listed is the ERPG-1 value for hexachlorobutadiene.

c. The Site Area Emergency and General Emergency protective action criteria value listed is the ERPG-2 value for hexachlorobutadiene.

d. The company guidelines for ERPGs and ERPG equivalents are discussed in the text. The ERPG-3 concentration of 30 ppm for hexachlorobutadiene was used.

e. NSC stands for No Significant Consequences. The estimated airborne concentration was not significant at this receptor location or the ERPG (or equivalent) concentration was not exceeded at $100 \mathrm{~m}$. 
Table C-54. Summary of event consequences for a release of hexachloroethane.

\begin{tabular}{|c|c|c|c|c|c|c|c|c|c|c|}
\hline \multirow[b]{2}{*}{ Release Type } & \multirow[b]{2}{*}{$\begin{array}{l}\text { Meteorological } \\
\text { conditions }\end{array}$} & \multicolumn{3}{|c|}{$\begin{array}{c}\text { Peak concentration (time to) } \\
(\mathbf{p p m}) \quad(\mathrm{min})\end{array}$} & \multicolumn{2}{|c|}{$\begin{array}{l}\text { Protective action criterian } \\
\text { (ppm) }\end{array}$} & \multirow{2}{*}{$\begin{array}{c}\text { Highest } \\
\text { emergency } \\
\text { class }\end{array}$} & \multicolumn{3}{|c|}{$\begin{array}{l}\text { Distance to ERPG or equivalent } \\
\qquad(\mathrm{m})\end{array}$} \\
\hline & & $100 \mathrm{~m}$ & $756 \mathrm{~m}$ & $5,200 \mathrm{~m}$ & Alert" & $\begin{array}{l}\text { Site Area or General } \\
\text { Emergency }{ }^{c}\end{array}$ & & $\begin{array}{l}\text { ERPG-1 or } \\
\text { equivalent }\end{array}$ & $\begin{array}{l}\text { ERPG- } 2 \text { or } \\
\text { equivalent }\end{array}$ & $\begin{array}{l}\text { ERPG- } 3 \text { or } \\
\text { equivalent }\end{array}$ \\
\hline & $95 \%$ worst-case & $8.24(5)$ & $0.177(20)$ & $N S C^{e}$ & 3 & 5 & Site Area & 168 & 130 & $\mathrm{NSC}$ \\
\hline \multicolumn{11}{|l|}{ Direct } \\
\hline & Typical & $0.458(2)$ & $\mathrm{NSC}$ & NSC & 3 & 5 & - & NSC & $\mathrm{NSC}$ & NSC \\
\hline
\end{tabular}

a. Protective action criteria are based on company guidelines for determining event classification. The definitions for event classifications of hazardous material releases at the INEL, are discussed in the text.

b. The Alent protective action criteria value listed is the ERPG-1 equivalent (3*TLV-TWA) value for hexachloroethane.

c. The Site Area Emergency and General Emergency protective action criteria value listed is the ERPG-2 equivalent (5*TLV-TWA) value for hexachloroethane.

d. The company guidelines for ERPGs and ERPG equivalents are discussed in the text. The ERPG-3 equivalent (IDLH) concentration of 300 ppm for hexachloroethane was used

e. NSC stands for No Significant Consequences. The estimated airborne concentration was not significant at this receptor location or the ERPG (or equivalent) concentration was not exceeded at $100 \mathrm{~m}$. 
Table C-55. Summary of event consequences for a release of hexone (methyl isobutyl ketone).

\begin{tabular}{|c|c|c|c|c|c|c|c|c|c|c|}
\hline \multirow[b]{2}{*}{ Release Type } & \multirow[b]{2}{*}{$\begin{array}{l}\text { Meteorological } \\
\text { conditions }\end{array}$} & \multicolumn{3}{|c|}{$\begin{array}{l}\text { Peak concentration (time to) } \\
\begin{array}{c}\text { (ppm) } \\
(\mathrm{min})\end{array}\end{array}$} & \multicolumn{2}{|c|}{$\begin{array}{l}\text { Protective action criterian } \\
\text { (ppm) }\end{array}$} & \multirow{2}{*}{$\begin{array}{c}\text { Highest } \\
\text { emergency } \\
\text { class }\end{array}$} & \multicolumn{3}{|c|}{$\begin{array}{l}\text { Distance to ERPG or equivalent } \\
\qquad(\mathbf{m})\end{array}$} \\
\hline & & $100 \mathrm{~m}$ & $756 \mathrm{~m}$ & $5,200 \mathrm{~m}$ & Aler $^{b}$ & $\begin{array}{c}\text { Site Area or General } \\
\text { Emergency }^{c}\end{array}$ & & $\begin{array}{l}\text { ERPG-1 or } \\
\text { equivalent }\end{array}$ & $\begin{array}{l}\text { ERPG-2 or } \\
\text { equivalent }\end{array}$ & $\begin{array}{l}\text { ERPG } 3 \text { or } \\
\text { equivalent }\end{array}$ \\
\hline & $95 \%$ worst-case & $190(4)$ & $7.33(22)$ & $\mathrm{NSC}^{\mathrm{e}}$ & 75 & 250 & Alen & 175 & NSC & NSC \\
\hline \multicolumn{11}{|l|}{ Direct } \\
\hline & Typical & $110(3)$ & $2.77(6)$ & NSC & 75 & 250 & Alen & 125 & NSC & NSC \\
\hline & $95 \%$ worst-case & $12(5)$ & NSC & NSC & 75 & 250 & $\therefore$ & NSC & NSC & $\mathrm{NSC}$ \\
\hline \multicolumn{11}{|l|}{ Spill } \\
\hline & Typical & $2.59(2)$ & NSC & NSC & 75 & 250 & - & NSC & NSC & NSC \\
\hline & $95 \%$ worst-case & $84.9(5)$ & $3.67(22)$ & NSC & 75 & 250 & Alert & 107 & NSC & NSC \\
\hline \multicolumn{11}{|l|}{ Spill w/ fire } \\
\hline & Typical & $43.9(3)$ & NSC & NSC & 75 & 250 & - & NSC & NSC & NSC \\
\hline
\end{tabular}

a. Protective action criteria are based on company guidelines for determining event classification. The definitions for event classifications of hazardous material releases at the INEL are discussed in the text.

b. The Alen protective action criteria value listed is the ERPG-1 equivalent (TLV-STEL) value for hexone (methyl isobutyl ketone)

c. The Site Area Emergency and General Emergency protective action criteria value listed is the ERPG-2 equivalent (5*TLV-TWA) value for hexone (methyl isobutyl ketone)

d. The company guidelines for ERPGs and ERPG equivalents are discussed in the text. The ERPG-3 equivalent (IDLH) concentration of 3,000 ppm for hexone (methyl isobutyl ketone) was used.

e. NSC stands for No Significant Consequences. The estimated airborne concentration was not significant at this receptor location or the ERPG (or equivalent) concentration was not exceeded at $100 \mathrm{~m}$. 
Table C-56. Summary of event consequences for a release of lead.

\begin{tabular}{|c|c|c|c|c|c|c|c|c|c|c|}
\hline \multirow[b]{2}{*}{ Release Type } & \multirow[b]{2}{*}{$\begin{array}{c}\text { Meteorological } \\
\text { conditions }\end{array}$} & \multicolumn{3}{|c|}{$\begin{array}{c}\text { Peak concentration (time to) } \\
\begin{array}{c}\left(\mathrm{mg} / \mathrm{m}^{3}\right) \\
(\mathrm{min})\end{array}\end{array}$} & \multicolumn{2}{|c|}{$\begin{array}{l}\text { Protective action criteria } \\
\left(\mathbf{m g} / \mathbf{m}^{3}\right)\end{array}$} & \multirow{2}{*}{$\begin{array}{c}\text { Highest } \\
\text { emergency } \\
\text { class }\end{array}$} & \multicolumn{3}{|c|}{$\begin{array}{l}\text { Distance to ERPG or equivalend } \\
\text { (m) }\end{array}$} \\
\hline & & $100 \mathrm{~m}$ & $756 \mathrm{~m}$ & $5,200 \mathrm{~m}$ & Alert ${ }^{b}$ & $\begin{array}{l}\text { Site Area or General } \\
\text { Emergency }^{c}\end{array}$ & & $\begin{array}{l}\text { ERPG-1 or } \\
\text { equivalent }\end{array}$ & $\begin{array}{l}\text { ERPG-2 or } \\
\text { equivalent }\end{array}$ & $\begin{array}{l}\text { ERPG-3 or } \\
\text { equivalent }\end{array}$ \\
\hline \multirow{3}{*}{ Direct } & $95 \%$ worst-case & $0.25(2)$ & $1.8 \mathrm{E}-3(13)$ & $\mathrm{NSC}^{\mathrm{K}}$ & 0.45 & 0.75 & - & NSC & NSC & NSC \\
\hline & & & & & & & & & & \\
\hline & Typical & $0.04(1)$ & $8.6 \mathrm{E}-4(5)$ & NSC & 0.45 & 0.75 & - & NSC & NSC & NSC \\
\hline
\end{tabular}

a. Protective action criteria are based on company guidelines for determining event classification. The definitions for event classifications of hazardous material releases at the INEL are discussed in the text.

b. The Alert protective action criteria value listed is the ERPG-1 equivalent (3*TLV-TWA) value for lead.

c. The Site Area Emergency and General Emergency protective action criteria value listed is the ERPG-2 equivalent (5*TLV-TWA) value for lead.

d. The company guidelines for ERPGs and ERPG equivalents are discussed in the text. The ERPG-3 equivalent (IDIH) concentration of $700 \mathrm{mg} / \mathrm{m}^{3}$ for lead was used.

e. NSC stands for No Significant Consequences. The estimated airborne concentration was not significant at this receptor location or the ERPG (or equivalent) concentration was not exceeded at $100 \mathrm{~m}$. 
Table C-57. Summary of event consequences for a release of lindane $(454 \mathrm{~kg})$.

\begin{tabular}{|c|c|c|c|c|c|c|c|c|c|c|}
\hline \multirow[b]{2}{*}{ Release Type } & \multirow[b]{2}{*}{$\begin{array}{l}\text { Meteorological } \\
\text { conditions }\end{array}$} & \multicolumn{3}{|c|}{$\begin{array}{l}\text { Peak concentration (time to) } \\
\left(\mathrm{mg} / \mathrm{m}^{3}\right) \quad(\mathrm{min})\end{array}$} & \multicolumn{2}{|c|}{$\begin{array}{l}\text { Protective action criteria } \\
\left(\mathrm{mg} / \mathrm{m}^{3}\right)\end{array}$} & \multirow{2}{*}{$\begin{array}{l}\text { Highest } \\
\text { emergency } \\
\text { class }\end{array}$} & \multicolumn{3}{|c|}{$\begin{array}{l}\text { Distance to ERPG or equivalent } \\
\text { (m) }\end{array}$} \\
\hline & & $100 \mathrm{~m}$ & $756 \mathrm{~m}$ & $5,200 \mathrm{~m}$ & Alert ${ }^{b}$ & $\begin{array}{l}\text { Site Area or General } \\
\text { Emergency }\end{array}$ & & $\begin{array}{l}\text { ERPG-1 or } \\
\text { equivalent }\end{array}$ & $\begin{array}{l}\text { ERPG-2 or } \\
\text { equivalent }\end{array}$ & $\begin{array}{l}\text { ERPG-3 or } \\
\text { equivalent }\end{array}$ \\
\hline \multirow{3}{*}{ Direct } & $95 \%$ worst-case & $250(2)$ & $1.8(13)$ & $0.018(87)$ & 1.5 & 2.5 & Site Area & 820 & 650 & NSCe \\
\hline & & & & & & & & & & \\
\hline & Typical & $40(1)$ & $0.86(5)$ & NSC & 1.5 & 2.5 & Site Area & 550 & 420 & NSC \\
\hline
\end{tabular}

a. Protective action criteria are based on company guidelines for determining event classification. The definitions for event classifications of hazardous material relenses at the INEL are discussed in the text

b. The Alen protective action criteria value listed is the ERPG-I equivalent $\left(3^{*} \mathrm{TLV}-\mathrm{TWA}\right)$ value for lindane

c. The Site Area Emergency and General Emergency protective action criteria value listed is the ERPG-2 equivalent ( $5^{*}$ TLV-TWA) value for lindane.

d. The company guidelines for ERPGs and ERPG equivalents are discussed in the text. The ERPG-3 equivalent (IDLH) concentration of $1,000 \mathrm{mg} / \mathrm{m}^{3}$ for lindane was used.

e. NSC stands for No Significant Consequences. The estimated airborne concentration was not significant at this receptor location or the ERPG (or equivalent) concentration was not exceeded at $100 \mathrm{~m}$. 
Table C-58. Summary of event consequences for a release of lindane $(4,540 \mathrm{~kg})$.

\begin{tabular}{|c|c|c|c|c|c|c|c|c|c|c|}
\hline \multirow[b]{2}{*}{ Releuse Type } & \multirow[b]{2}{*}{$\begin{array}{l}\text { Meteorological } \\
\text { conditions }\end{array}$} & \multicolumn{3}{|c|}{$\begin{array}{l}\text { Peak concentration (time to) } \\
\left(\mathrm{mg} / \mathrm{m}^{3}\right) \quad(\mathrm{min})\end{array}$} & \multicolumn{2}{|c|}{$\begin{array}{c}\text { Protective action criteria } \\
\left(\mathrm{mg} / \mathrm{m}^{3}\right)\end{array}$} & \multirow{2}{*}{$\begin{array}{l}\text { Highest } \\
\text { emergency } \\
\text { class }\end{array}$} & \multicolumn{3}{|c|}{$\begin{array}{l}\text { Distance to ERPG or equivalent } \\
(\mathrm{m})\end{array}$} \\
\hline & & $100 \mathrm{~m}$ & $756 \mathrm{~m}$ & $5,200 \mathrm{~m}$ & Aler $^{\mathrm{b}}$ & $\begin{array}{l}\text { Site Area or General } \\
\text { Emergency }{ }^{\mathbf{c}}\end{array}$ & & $\begin{array}{l}\text { ERPG-1 or } \\
\text { equivalent }\end{array}$ & $\begin{array}{l}\text { ERPG- } 2 \text { or } \\
\text { equivalent }\end{array}$ & $\begin{array}{l}\text { ERPG-3 or } \\
\text { equivalent }\end{array}$ \\
\hline \multirow{3}{*}{ Direct } & $95 \%$ worst-case & $2,500(2)$ & $18(13)$ & $0.18(87)$ & 1.5 & 2.5 & Site Area & 2,100 & 1,720 & 150 \\
\hline & & & & & & & & & & \\
\hline & Typical & $400(1)$ & $8.6(5)$ & $0.35(35)$ & 1.5 & 2.5 & Site Area & 2,100 & 1,500 & $\mathrm{NSC}^{\mathrm{C}}$ \\
\hline
\end{tabular}

a. Protective action criteria are based on company guidelines for determining event classification. The definitions for event classifications of hazardous material releases at the INEL are discussed in the text.

b. The Alert protective action criteria value listed is the ERPG-1 equivalent (3*TLV-TWA) value for tindane

c. The Site Area Emergency and General Emergency protective action criteria value listed is the ERPG-2 equivalent (5*TLV-TWA) value for lindane.

d. The company guidelines for ERPGs and ERPG equivalents are discussed in the text. The ERPG-3 equivalent (IDLH) concentration of $1,000 \mathrm{mg} / \mathrm{m}^{3}$ for lindane was used.

e. NSC stands for No Significant Consequences. The estimated airborne concentration was not significant at this receptor location or the ERPG (or equivalent) concentration was not exceeded at $100 \mathrm{~m}$. 
Table C-59. Summary of event consequences for a release of mercury.

\begin{tabular}{|c|c|c|c|c|c|c|c|c|c|c|}
\hline \multirow[b]{2}{*}{ Release Type } & \multirow[b]{2}{*}{$\begin{array}{c}\text { Meteorological } \\
\text { conditions } \\
\end{array}$} & \multicolumn{3}{|c|}{$\begin{array}{c}\begin{array}{c}\text { Peak concentration (time to) } \\
\left(\mathrm{mg} / \mathrm{m}^{3}\right)\end{array} \quad(\mathrm{min}) \\
\end{array}$} & \multicolumn{2}{|c|}{$\begin{array}{l}\text { Protective action criteria } \\
\qquad\left(\mathrm{mg} / \mathrm{m}^{3}\right)\end{array}$} & \multirow{2}{*}{$\begin{array}{c}\text { Highest } \\
\text { emergency } \\
\text { class }\end{array}$} & \multicolumn{3}{|c|}{$\begin{array}{l}\text { Distance to ERPG or equivalent }{ }^{d} \\
(\mathbf{m})\end{array}$} \\
\hline & & $100 \mathrm{~m}$ & $756 \mathrm{~m}$ & $5,200 \mathrm{~m}$ & Alert $^{b}$ & $\begin{array}{l}\text { Site Area or General } \\
\text { Emergency }{ }^{c}\end{array}$ & & $\begin{array}{l}\text { ERPG-1 or } \\
\text { equivalent }\end{array}$ & $\begin{array}{l}\text { ERPG-2 or } \\
\text { equivalent }\end{array}$ & $\begin{array}{l}\text { ERPG }-3 \text { or } \\
\text { equivalent }\end{array}$ \\
\hline & $95 \%$ worst-case & $0.72(2)$ & $0.014(13)$ & $\mathrm{NSC}^{\mathrm{e}}$ & 0.03 & 0.2 & Site Area & 500 & 180 & NSC \\
\hline \multicolumn{11}{|l|}{ Direct } \\
\hline & Typical & 0.044 (1) & $1.1 \mathrm{E}-3(5)$ & NSC & 0.03 & 0.2 & Alent & 130 & NSC & NSC \\
\hline & $95 \%$ worst-case & $1.9 \mathrm{E}-5(2)$ & NSC & NSC & 0.03 & 0.2 & - & NSC & NSC & NSC \\
\hline \multicolumn{11}{|l|}{ Spill } \\
\hline & Typical & $1.2 \mathrm{E}-6(1)$ & NSC & NSC & 0.03 & 0.2 & - & NSC & $\mathrm{NSC}$ & NSC \\
\hline & $95 \%$ worst-case & $2.5 \mathrm{E}-3(2)$ & NSC & NSC & 0.03 & 0.2 & - & NSC & NSC & NSC \\
\hline \multicolumn{11}{|l|}{ Spill w/fire } \\
\hline & Typical & $3.2 \mathrm{E}-4(1)$ & NSC & NSC & 0.03 & 0.2 & & NSC & NSC & NSC \\
\hline
\end{tabular}

a. Protective action criteria are based on company guidelines for determining event classification. The definitions for event classifications of hazardous material releases at the INEL are discussed in the text.

b. The Alert protective action criteria value listed is the ERPG-1 equivalent (TLV-STEL) value for mercury.

c. The Site Area Emergency and General Emergency protective action criteria value listed is the ERPG-2 equivalent (EEGL-60) value for mercury.

d. The company guidelines for ERPGs and ERPG equivalents are discussed in the text. The ERPG-3 equivalent (IDLH) concentration of $10 \mathrm{mg} / \mathrm{m}^{3}$ for mercury was used.

e. NSC stands for No Significant Consequences. The estimated airborne concentration was not significant at this receptor location or the ERPG (or equivalent) concentration was not exceeded at $100 \mathrm{~m}$. 
Table C-60. Summary of event consequences for a release of methanol (methyl alcohol).

\begin{tabular}{|c|c|c|c|c|c|c|c|c|c|c|}
\hline \multirow[b]{2}{*}{ Release Type } & \multirow[b]{2}{*}{$\begin{array}{l}\text { Meteorological } \\
\text { conditions }\end{array}$} & \multicolumn{3}{|c|}{ 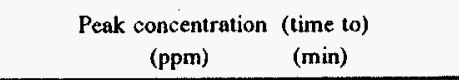 } & \multicolumn{2}{|c|}{$\begin{array}{l}\text { Protective action criteria" } \\
\text { (ppm) }\end{array}$} & \multirow{2}{*}{$\begin{array}{c}\text { Highest } \\
\text { emergency } \\
\text { class }\end{array}$} & \multicolumn{3}{|c|}{$\begin{array}{l}\text { Distance to ERPG or equivalent }{ }^{d} \\
\text { (m) }\end{array}$} \\
\hline & & $100 \mathrm{~m}$ & $756 \mathrm{~m}$ & $5.200 \mathrm{~m}$ & Aler $^{b}$ & $\begin{array}{l}\text { Site Area or General } \\
\text { Emergency }^{c}\end{array}$ & & $\begin{array}{l}\text { ERPG-1 or } \\
\text { equivalent }\end{array}$ & $\begin{array}{l}\text { ERPG-2 or } \\
\text { equivalent }\end{array}$ & $\begin{array}{l}\text { ERPG-3 or } \\
\text { equivalenı }\end{array}$ \\
\hline & $95 \%$ worst-case & $744(3)$ & $32.2(17)$ & $\mathrm{NSC}^{\mathrm{c}}$ & 200 & 1,000 & Alen & 225 & NSC & NSC \\
\hline \multicolumn{11}{|l|}{ Direct } \\
\hline & Typical & $350(3)$ & $8.65(5)$ & NSC & 200 & 1,000 & Alert & 135 & NSC & NSC \\
\hline & $95 \%$ worst-case & $179(4)$ & $4.02(18)$ & NSC & 200 & 1,000 & - & NSC & NSC & NSC \\
\hline \multicolumn{11}{|l|}{ Spill } \\
\hline & Typical & $18.2(2)$ & NSC & $\mathrm{NSC}$ & 200 & 1,000 & $\cdot$ & NSC & NSC & NSC \\
\hline & $95 \%$ worst-case & $909(5)$ & $37.8(20)$ & NSC & 200 & 1,000 & Alert & 250 & NSC & NSC \\
\hline \multicolumn{11}{|l|}{ Spill w/ fire } \\
\hline & Typical & $305(3)$ & $7.58(10)$ & NSC & 200 & 1,000 & Alent & 125 & NSC & NSC \\
\hline
\end{tabular}

a. Protective action criteria are based on company guidelines for determining event classification. The definitions for event classifications of hazardous material releases at the INEL are discussed in the text.

b. The Alert protective action criteria value listed is the ERPG-1 value for methanol (methyl alcohol).

c. The Site Area Emergency and General Emergency protective action criteria value listed is the ERPG-2 value for methanol (methyl alcohol).

d. The company guidelines for ERPGs and ERPG equivalents are discussed in the text. The ERPG-3 concentration of 5,000 ppm for methanol (methyl alcohol) was used.

e. NSC stands for No Significant Consequences. The estimated airborne concentration was not significant at this receptor location or the ERPG (or equivalent) concentration was not exceeded at $100 \mathrm{~m}$ 
Table C-61. Summary of event consequences for a release of methoxychlor.

\begin{tabular}{|c|c|c|c|c|c|c|c|c|c|c|}
\hline \multirow[b]{2}{*}{ Release Type } & \multirow[b]{2}{*}{$\begin{array}{l}\text { Meteorological } \\
\text { conditions }\end{array}$} & \multicolumn{3}{|c|}{ 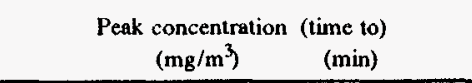 } & \multicolumn{2}{|c|}{$\begin{array}{l}\text { Protective action criteria" } \\
\left(\mathrm{mg} / \mathrm{m}^{3}\right)\end{array}$} & \multirow{2}{*}{$\begin{array}{c}\text { Highest } \\
\text { emergency } \\
\text { class }\end{array}$} & \multicolumn{3}{|c|}{$\begin{array}{l}\text { Distance to ERPG or equivalent } \\
\qquad(\mathrm{m})\end{array}$} \\
\hline & & $100 \mathrm{~m}$ & $756 \mathrm{~m}$ & $5,200 \mathrm{~m}$ & Alert $^{6}$ & $\begin{array}{l}\text { Site Area or General } \\
\text { Emergencyc }\end{array}$ & & $\begin{array}{c}\text { ERPG-1 or } \\
\text { equivalent }\end{array}$ & $\begin{array}{l}\text { ERPG-2 or } \\
\text { equivalent }\end{array}$ & $\begin{array}{l}\text { ERPG-3 or } \\
\text { equivalent }\end{array}$ \\
\hline & $95 \%$ worst-case & $0.25(2)$ & $1.8 \mathrm{E}-3(13)$ & $\mathrm{NSC}^{\mathrm{e}}$ & 30 & 50 & - & NSC & $\mathrm{NSC}$ & $\mathrm{NLA}^{\mathrm{f}}$ \\
\hline \multicolumn{11}{|l|}{ Direct } \\
\hline & Typical & $0.04(1)$ & $8.6 \mathrm{E}-4(5)$ & NSC & 30 & 50 & - & NSC & NSC & NLA \\
\hline \multicolumn{11}{|c|}{ Prolective action criteria are based on company guidelines for determining event classification. The definitions for event classifications of hazardous material releases at the INEL are discussed in the text. } \\
\hline \multicolumn{11}{|c|}{ The Alert protective action criteria value listed is the ERPG-1 equivalent ( $3 *$ TLV-TWA) value for methoxychlor. } \\
\hline \multicolumn{11}{|c|}{ The Site Area Emergency and General Emergency protective action criteria value listed is the ERPG-2 equivalent ( $5^{*}$ TLV-TWA) value for methoxychlor. } \\
\hline \multicolumn{11}{|c|}{ The company guidelines for ERPGs and ERPG equivalents are discussed in the text. There is no ERPG-3 or equivalent concentration for methoxychlor. } \\
\hline \multicolumn{11}{|c|}{ NSC stands for No Significant Consequences. The estimated airborne concentration was not significant at this receptor location or the ERPG (or equivalent) concentration was not exceeded at $100 \mathrm{~m}$. } \\
\hline \multicolumn{11}{|c|}{ NLA stands for No Limit Available. NLA indicates that an ERPG or equivalent concentration limit was not available for the hazardous material. } \\
\hline
\end{tabular}


Table C-62. Summary of event consequences for a release of methyl ethyl ketone.

\begin{tabular}{|c|c|c|c|c|c|c|c|c|c|c|}
\hline \multirow[b]{2}{*}{ Release Type } & \multirow[b]{2}{*}{$\begin{array}{l}\text { Meteorological } \\
\text { conditions }\end{array}$} & \multicolumn{3}{|c|}{$\begin{array}{l}\text { Peak concentration (time to) } \\
(\mathrm{ppm}) \quad(\mathrm{min})\end{array}$} & \multicolumn{2}{|c|}{$\begin{array}{l}\text { Protective action criterian } \\
\text { (ppm) }\end{array}$} & \multirow{2}{*}{$\begin{array}{l}\text { Highest } \\
\text { emergency } \\
\text { class }\end{array}$} & \multicolumn{3}{|c|}{$\begin{array}{l}\text { Distance to ERPG or equivalent } \\
\qquad(\mathrm{m})\end{array}$} \\
\hline & & $100 \mathrm{~m}$ & $756 \mathrm{~m}$ & $5,200 \mathrm{~m}$ & Alert ${ }^{b}$ & $\begin{array}{l}\text { Site Area or General } \\
\text { Emergencyc }\end{array}$ & & $\begin{array}{l}\text { ERPG-1 or } \\
\text { equivalent }\end{array}$ & $\begin{array}{l}\text { ERPG-2 or } \\
\text { equivalent }\end{array}$ & $\begin{array}{l}\text { ERPG-3 or } \\
\text { equivalent }\end{array}$ \\
\hline & $95 \%$ worst-case & $272(5)$ & $\mathrm{NSC}^{\mathrm{e}}$ & NSC & 300 & 1,000 & - & NSC & NSC & NSC \\
\hline \multicolumn{11}{|l|}{ Direct } \\
\hline & Typical & $159(4)$ & NSC & NSC & 300 & 1,000 & - & NSC & NSC & NSC \\
\hline & $95 \%$ worst-case & $42.2(4)$ & NSC & $\mathrm{NSC}$ & 300 & 1,000 & - & NSC & NSC & NSC \\
\hline \multicolumn{11}{|l|}{ Spill } \\
\hline & Typical & $13.3(2)$ & NSC & NSC & 300 & 1,000 & - & NSC & NSC & NSC \\
\hline & $95 \%$ worst-case & $659(10)$ & $21.3(30)$ & NSC & 300 & 1,000 & Alert & 155 & NSC & NSC \\
\hline \multicolumn{11}{|l|}{ Spill w/ fire } \\
\hline & Typicàl & $482(7)$ & $17.5(10)$ & NSC & 300 & 1,000 & Alert & 136 & NSC & NSC \\
\hline
\end{tabular}

a. Protective action criteria are based on company guidelines for determining event classification. The definitions for event classifications of hazardous material releases at the INEL are discussed in the text.

b. The Alert protective action criteria value listed is the ERPG-1 equivalent (TLV-STEL) value for methyl ethyl ketone.

c. The Site Area Emergency and General Emergency protective action criteria value listed is the ERPG-2 equivalent (TLV-C) value for methyl ethyl ketone.

d. The company guidelines for ERPGs and ERPG equivalents are discussed in the text. The ERPG-3 equivalent (IDLH) concentration of $3,000 \mathrm{ppm}$ for methyl ethyl ketone was used.

e. NSC stands for No Significant Consequences. The estimated airborne concentration was not significant at this receptor location or the ERPG (or equivalent) concentration was not exceeded at $100 \mathrm{~m}$. 
Table C-63. Summary of event consequences for a release of methylene chloride.

\begin{tabular}{|c|c|c|c|c|c|c|c|c|c|c|}
\hline \multirow[b]{2}{*}{ Release Type } & \multirow[b]{2}{*}{$\begin{array}{l}\text { Meteorological } \\
\text { conditions }\end{array}$} & \multicolumn{3}{|c|}{$\begin{array}{c}\begin{array}{c}\text { Peak concentration (time to) } \\
(\mathrm{ppm})\end{array} \quad(\mathrm{min}) \\
\end{array}$} & \multicolumn{2}{|c|}{$\begin{array}{l}\text { Protective action criteria } \\
\text { (ppm) }\end{array}$} & \multirow{2}{*}{$\begin{array}{c}\text { Highest } \\
\text { emergency } \\
\text { class }\end{array}$} & \multicolumn{3}{|c|}{$\begin{array}{l}\begin{array}{l}\text { Distance to ERPG or equivalent } \\
(\mathrm{m})\end{array} \\
\end{array}$} \\
\hline & & $100 \mathrm{~m}$ & $756 \mathrm{~m}$ & $5,200 \mathrm{~m}$ & Aler $^{b}$ & $\begin{array}{l}\text { Site Area or General } \\
\text { Emergency }^{\mathrm{c}}\end{array}$ & & $\begin{array}{l}\text { ERPG-1 or } \\
\text { equivalent }\end{array}$ & $\begin{array}{l}\text { ERPG-2 or } \\
\text { equivalent }\end{array}$ & $\begin{array}{l}\text { ERPG-3 or } \\
\text { equivalent }\end{array}$ \\
\hline & $95 \%$ worst-case & $210(2)$ & $4.0(13)$ & NSCe & 150 & 400 & Alen & 125 & NSC & $\mathrm{NSC}$ \\
\hline \multicolumn{11}{|l|}{ Direct } \\
\hline & Typical & $13(1)$ & $\mathrm{NSC}$ & NSC & 150 & 400 & $\dot{-}$ & NSC & NSC & $\mathrm{NSC}$ \\
\hline & $95 \%$ worst-case & $200(2)$ & $5.2(13)$ & NSC & 150 & 400 & Alert & 125 & $\mathrm{NSC}$ & $\mathrm{NSC}$ \\
\hline \multicolumn{11}{|l|}{ Spill } \\
\hline & Typical & $14(1)$ & NSC & NSC & 150 & 400 & - & NSC & NSC & NSC \\
\hline \multirow{3}{*}{ Spill w/ fire } & $95 \%$ worst-case & $390(2)$ & $10(13)$ & $\mathrm{NSC}$ & 150 & 400 & Alert & 175 & NsC & NSC \\
\hline & & & & & & & & & & \\
\hline & Typical & $58(1)$ & $1.7(5)$ & $\mathrm{NSC}$ & 150 & 400 & . & NSC & NSC & NSC \\
\hline
\end{tabular}

a. Protective action criteria are based on company guidelines for determining event classification. The definitions for event classifications of hazardous material releases at the INEL are discussed in the text.

b. The Alert protective action criteria value listed is the ERPG-1 equivalent ( $3 *$ TLV-TWA) value for methylene chloride.

c. The Site Area Emergency and General Emergency protective action criteria value listed is the ERPG-2 value for methylene chloride.

d. The company guidelines for ERPGs and ERPG equivalents are discussed in the text. The ERPG-3 concentration of 1,000 ppm for methylene chloride was used.

e. NSC stands for No Significant Consequences. The estimated airborne concentration was not significant at this receptor location or the ERPG (or equivalent) concentration was not exceeded at $100 \mathrm{~m}$. 
Table C-64. Summary of event consequences for a release of naphthalene.

\begin{tabular}{|c|c|c|c|c|c|c|c|c|c|c|}
\hline \multirow[b]{2}{*}{ Release Type } & \multirow[b]{2}{*}{$\begin{array}{l}\text { Meteorological } \\
\text { conditions }\end{array}$} & \multicolumn{3}{|c|}{$\begin{array}{cc}\begin{array}{c}\text { Peak concentration (time to) } \\
(\mathrm{ppm})\end{array} & (\mathrm{min}) \\
\end{array}$} & \multicolumn{2}{|c|}{$\begin{array}{l}\text { Protective action criteria } \\
\text { (ppm) }\end{array}$} & \multirow{2}{*}{$\begin{array}{l}\text { Highest } \\
\text { emergency } \\
\text { class }\end{array}$} & \multicolumn{3}{|c|}{$\begin{array}{l}\text { Distance to ERPG or equivalent }{ }^{d} \\
(\mathrm{~m})\end{array}$} \\
\hline & & $100 \mathrm{~m}$ & $756 \mathrm{~m}$ & $5,200 \mathrm{~m}$ & Aler ${ }^{b}$ & $\begin{array}{l}\text { Site Area or General } \\
\text { Emergency }\end{array}$ & & $\begin{array}{l}\text { ERPG-1 or } \\
\text { equivalent }\end{array}$ & $\begin{array}{l}\text { ERPG-2 or } \\
\text { equivalent }\end{array}$ & $\begin{array}{l}\text { ERPG-3 or } \\
\text { equivalent }\end{array}$ \\
\hline \multirow{3}{*}{ Direat } & $95 \%$ worst-case & $6.56(5)$ & $0.254(23)$ & $\mathrm{NSC}^{\mathrm{e}}$ & 15 & 50 & - & NSC & NSC & NSC \\
\hline & & & & & & & & & & \\
\hline & Typical & $1.89(3)$ & NSC & NSC & 15 & 50 & - & NSC & NSC & NSC \\
\hline
\end{tabular}

a. Protective action criteria are based on company guidelines for determining event classification. The definitions for event classifications of hazardous material releases at the INEL, are discussed in the text.

b. The Alert protective action criteria value listed is the ERPG-1 equivalent (TLV-STEL) value for naphthalene.

c. The Sitc Area Emergency and General Emergency protective action criteria value listed is the ERPG-2 equivalent $\left(5^{*}\right.$ TL.V-TWA) value for naphthalene.

d. The company guidelines for ERPGs and ERPG equivalents are discussed in the text. The ERPG-3 equivalent (IDLH) concentration of 500 ppm for naphthalene was used.

e. NSC stands for No Significant Consequences. The estimated airborne concentration was not significant at this receptor location or the ERPG (or equivalent) concentration was not exceeded at $100 \mathrm{~m}$. 
Table C-65. Summary of event consequences for a release of nitric acid.

\begin{tabular}{|c|c|c|c|c|c|c|c|c|c|c|}
\hline \multirow[b]{2}{*}{ Release Type } & \multirow[b]{2}{*}{$\begin{array}{l}\text { Meteorological } \\
\text { conditions }\end{array}$} & \multicolumn{3}{|c|}{$\begin{array}{l}\text { Peak concentration (time to) } \\
\begin{array}{c}(\mathrm{ppm}) \\
(\mathrm{min})\end{array}\end{array}$} & \multicolumn{2}{|c|}{$\begin{array}{l}\text { Protective action criterian } \\
\text { (ppm) }\end{array}$} & \multirow{2}{*}{$\begin{array}{l}\text { Highest } \\
\text { emergency } \\
\text { class }\end{array}$} & \multicolumn{3}{|c|}{$\begin{array}{c}\text { Distance to ERPG or equivalent }{ }^{d} \\
(\mathrm{~m})\end{array}$} \\
\hline & & $100 \mathrm{~m}$ & $756 \mathrm{~m}$ & $5,200 \mathrm{~m}$ & Alert $^{\mathrm{b}}$ & $\begin{array}{l}\text { Site Area or General } \\
\text { Emergency }{ }^{\mathrm{c}}\end{array}$ & & $\begin{array}{l}\text { ERPG-1 or } \\
\text { equivalent }\end{array}$ & $\begin{array}{l}\text { ERPG- } 2 \text { or } \\
\text { equivalent }\end{array}$ & $\begin{array}{l}\text { ERPG-3 or } \\
\text { equivalent }\end{array}$ \\
\hline & $95 \%$ worst-case & $84.6(5)$ & $3.99(20)$ & $\mathrm{NSC}^{\mathrm{e}}$ & 2 & 15 & Site Area & 1,100 & 300 & 200 \\
\hline \multicolumn{11}{|l|}{ Direct } \\
\hline & Typical & $37.6(3)$ & $0.885(5)$ & NSC & 2 & 15 & Site Area & 500 & 175 & 112 \\
\hline & $95 \%$ worst-case & $24.3(5)$ & $0.875(20)$ & $\mathrm{NSC}$ & 2 & 15 & Site Area & 458 & 135 & NSC \\
\hline \multicolumn{11}{|l|}{ Spill } \\
\hline & Typical & $5.54(1)$ & $0.138(5)$ & $\mathrm{NSC}$ & 2 & 15 & Site Area & 170 & NSC & NSC \\
\hline & $95 \%$ worst-case & $366(5)$ & $13.8(20)$ & $0.0518(60)$ & 2 & 15 & Site Area & 2,200 & 700 & 462 \\
\hline \multicolumn{11}{|l|}{ Spill w/ fire } \\
\hline & Typical & $343(3)$ & $8.8(5)$ & $1.91(15)$ & 2 & 15 & Site Area & 1,700 & 575 & 384 \\
\hline
\end{tabular}

a. Protective action criteria are based on company guidelines for determining event classification. The definitions for event classifications of hazardous material releases at the INEL are discussed in the text

b. The Alert protective action criteria value listed is the ERPG-1 value for nitric acid.

c. The Site Area Emergency and General Emergency protective action criteria value listed is the ERPG-2 value for nitric acid.

d. The company guidelines for ERPGs and ERPG equivalents are discussed in the text. The ERPG-3 concentration of 30 ppm for nitric acid was used. concentration for 1,2,4-trichlorobenzene.

e. NSC stands for No Significant Consequences. The estimated airborne concentration was not significant at this receptor location or the ERPG (or equivalent) concentration was not exceeded at $100 \mathrm{~m}$. 
Table C-66. Summary of event consequences for a release of nitrobenzene.

\begin{tabular}{|c|c|c|c|c|c|c|c|c|c|c|}
\hline \multirow[b]{2}{*}{ Release Type } & \multirow[b]{2}{*}{$\begin{array}{l}\text { Meteorological } \\
\text { conditions }\end{array}$} & \multicolumn{3}{|c|}{$\begin{array}{l}\text { Peak concentration (time to) } \\
\begin{array}{c}(\mathrm{ppm}) \\
(\mathrm{min})\end{array}\end{array}$} & \multicolumn{2}{|c|}{$\begin{array}{l}\text { Protective action criterira } \\
\text { (ppm) }\end{array}$} & \multirow{2}{*}{$\begin{array}{c}\text { Highest } \\
\text { emergency } \\
\text { class } \\
\end{array}$} & \multicolumn{3}{|c|}{$\begin{array}{l}\text { Distance to ERPG or equivalent } \\
\text { (m) }\end{array}$} \\
\hline & & $100 \mathrm{~m}$ & $756 \mathrm{~m}$ & $5,200 \mathrm{~m}$ & Aler $^{b}$ & $\begin{array}{l}\text { Site Area or General } \\
\text { Emergency }{ }^{c}\end{array}$ & & $\begin{array}{l}\text { ERPG-1 or } \\
\text { equivalent }\end{array}$ & $\begin{array}{l}\text { ERPG-2 or } \\
\text { equivalent }\end{array}$ & $\begin{array}{l}\text { ERPG-3 or } \\
\text { equivalent }\end{array}$ \\
\hline & $95 \%$ worst-case & $294(4)$ & $9.83(23)$ & $\mathrm{NSC}$ & 3 & 5 & Site Area & 1,600 & 1,100 & 119 \\
\hline \multicolumn{11}{|l|}{ Direct } \\
\hline & Typical & $143(3)$ & $4.4(8)$ & $0.12(27)$ & 3 & 5 & Site Area & 916 & 696 & NSC \\
\hline & $95 \%$ worst-case & $0.178(3)$ & NSC & NSC & 3 & 5 & - & NSC & NSC & NSC \\
\hline \multicolumn{11}{|l|}{ Spill } \\
\hline & Typical & $0.019(1)$ & NSC & NSC & 3 & 5 & - & NSC & NSC & NSC \\
\hline & $95 \%$ worst-case & $332(7)$ & $10.6(30)$ & NSC & 3 & 5 & Site Area & 1,700 & 1,200 & 127 \\
\hline \multicolumn{11}{|l|}{ Spill w/fire } \\
\hline & Typical & $246(3)$ & $3.84(21)$ & $0.093(50)$ & 3 & 5 & Site Area & 850 & 650 & 115 \\
\hline
\end{tabular}

a. Protective action criteria are based on company guidelines for determining event classification. The definitions for event classifications of hazardous material releases at the INEL are discussed in the text.

b. The Alen protective action criteria value listed is the ERPG-1 equivalent (3*TLV-TWA) value for nitrobenzene.

c. The Site Area Emergency and General Emergency protective action criteria value listed is the ERPG-2 equivalent (5*TWA-TLV) value for nitrobenzene.

d. The company guidelines for ERPGs and ERPG equivalents are discussed in the text. The ERPG-3 equivalent (IDLH) concentration of 200 ppm for nitrobenzene was used.

e. NSC stands for No Significant Consequences. The estimated airborne concentration was not significant at this receptor location or the ERPG (or equivalent) concentration was not exceeded at $100 \mathrm{~m}$. 
Table C-67. Summary of event consequences for a release of pentachlorophenol.

\begin{tabular}{|c|c|c|c|c|c|c|c|c|c|c|}
\hline \multirow[b]{2}{*}{ Release Type } & \multirow[b]{2}{*}{$\begin{array}{l}\text { Meteorological } \\
\text { conditions }\end{array}$} & \multicolumn{3}{|c|}{$\begin{array}{l}\text { Peak concentration (time to) } \\
\qquad\left(\mathrm{mg} / \mathrm{m}^{3}\right) \quad(\mathrm{min})\end{array}$} & \multicolumn{2}{|c|}{$\begin{array}{l}\text { Protective action criteria" } \\
\text { (ppm) }\end{array}$} & \multirow{2}{*}{$\begin{array}{c}\text { Highest } \\
\text { emergency } \\
\text { class }\end{array}$} & \multicolumn{3}{|c|}{$\begin{array}{l}\text { Distance to ERPG or equivalent }{ }^{d} \\
(\mathrm{~m})\end{array}$} \\
\hline & & $100 \mathrm{~m}$ & $756 \mathrm{~m}$ & $5,200 \mathrm{~m}$ & Alerr $^{b}$ & $\begin{array}{l}\text { Site Area or General } \\
\text { Emergency }\end{array}$ & & $\begin{array}{l}\text { ERPG-1 or } \\
\text { equivalent }\end{array}$ & $\begin{array}{l}\text { ERPG-2 or } \\
\text { equivalent }\end{array}$ & $\begin{array}{l}\text { ERPG-3 or } \\
\text { equivalent }\end{array}$ \\
\hline & $95 \%$ worst-case & $2.5(2)$ & $0.018(13)$ & $\mathrm{NSC}^{\mathrm{e}}$ & 1.5 & 2.5 & Site Area & 130 & 100 & NSC \\
\hline \multicolumn{11}{|l|}{ Direct } \\
\hline & Typical & $0.4(1)$ & $8.6 \mathrm{E}-3(5)$ & NSC & 1.5 & 2.5 & - & NSC & NSC & NSC \\
\hline
\end{tabular}

a. Protective action criteria are based on company guidelines for determining event classification. The definitions for event classifications of hazardous material releases at the INEL are discussed in the text.

b. The Alen protective action criteria value listed is the ERPG-1 equivalent (3*TLV-TWA) value for pentachiorophenol.

c. The Site Area Emergency and General Emergency protective action criteria value listed is the ERPG-2 equivalent (S*TLV-TWA) value for pentachlorophenol.

d. The company guidelines for ERPGis and ERPG equivalents are discussed in the text. The ERPG-3 equivalent (IDIH) concentration of $150 \mathrm{mg} / \mathrm{m}^{3}$ for pentachlorophenol was used.

e. NSC stands for No Significant Consequences. The estimated airborme concentration was not significant at this receptor location or the ERPG (or equivalent) concentration was not exceeded at $100 \mathrm{~m}$ 


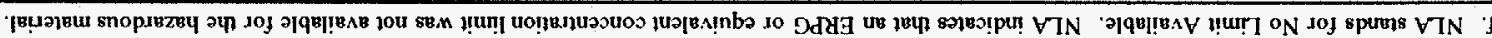

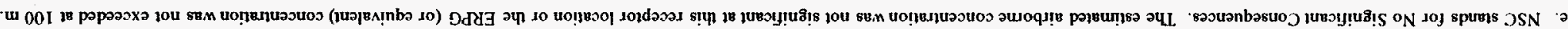

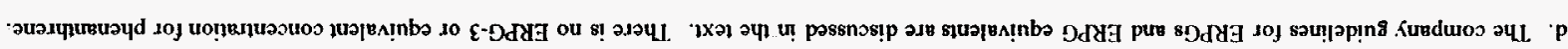

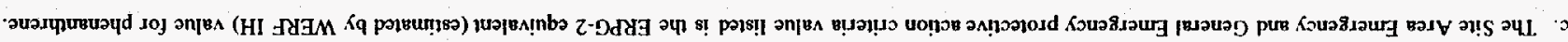

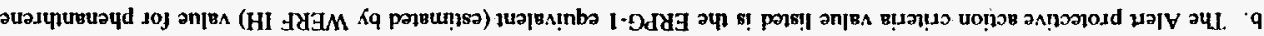

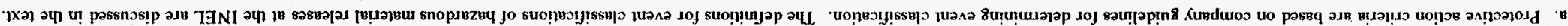

\begin{tabular}{|c|c|c|c|c|c|c|c|c|c|c|}
\hline$\forall 7 N$ & OSN & OSN & - & SEl & 18 & JSN & & (द) $8 \mathrm{~S}$ & [E्O!d $\kappa_{\mathbf{L}}$ & \multirow{2}{*}{ 1001! } \\
\hline , $V 1 N$ & OSN & $0 S I$ & นข้ & $\overline{\text { SEI }}$ & 18 & DSSN & $(\varepsilon z) \angle 6 \cdot \varepsilon$ & (5) $\mathrm{EOI}$ & $2880-15.50 \mathrm{~m} \% \mathrm{~S} 6$ & \\
\hline 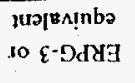 & 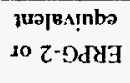 & 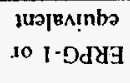 & \multirow{2}{*}{ 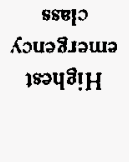 } & 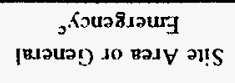 & qมอบ & ur $00 z^{\prime} s$ & u $9 S L$ & $\mathrm{w}_{001}$ & \multirow[t]{2}{*}{ 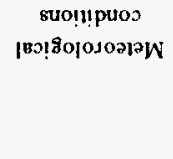 } & \multirow[t]{2}{*}{ วd $\delta_{\perp}$ әквәәәУ } \\
\hline 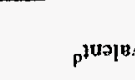 & $\begin{array}{c}\text { (u) } \\
\text { a so Dd4a o }\end{array}$ & 38!a & & $\begin{array}{r}\text { (urdd) } \\
\text { (1) }\end{array}$ & & & 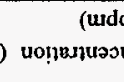 & & & \\
\hline
\end{tabular}


Table C-69. Summary of event consequences for a release of phenol $(227 \mathrm{~kg})$.

\begin{tabular}{|c|c|c|c|c|c|c|c|c|c|c|}
\hline \multirow[b]{2}{*}{ Release Type } & \multirow[b]{2}{*}{$\begin{array}{l}\text { Meteorological } \\
\text { conditions }\end{array}$} & \multicolumn{3}{|c|}{$\begin{array}{l}\text { Peak concentration (time to) } \\
\qquad(\mathrm{ppm}) \quad(\mathrm{min})\end{array}$} & \multicolumn{2}{|c|}{$\begin{array}{l}\text { Protective action criteria } \\
\text { (ppm) }\end{array}$} & \multirow{2}{*}{$\begin{array}{c}\begin{array}{c}\text { Highest } \\
\text { emergency } \\
\text { class }\end{array} \\
\end{array}$} & \multicolumn{3}{|c|}{$\begin{array}{l}\text { Distance to ERPG or equivalent }{ }^{d} \\
(\mathrm{~m})\end{array}$} \\
\hline & & $100 \mathrm{~m}$ & $756 \mathrm{~m}$ & $5,200 \mathrm{~m}$ & Alern $^{b}$ & $\begin{array}{l}\text { Site Area or General } \\
\text { Emergency }{ }^{\mathrm{c}}\end{array}$ & & $\begin{array}{l}\text { ERPG-1 or } \\
\text { equivalent }\end{array}$ & $\begin{array}{l}\text { ERPG-2 or } \\
\text { equivalent }\end{array}$ & $\begin{array}{l}\text { ERPG-3 or } \\
\text { equivalent }\end{array}$ \\
\hline \multirow{3}{*}{ Direct } & $95 \%$ worst-case & $31.3(5)$ & $1.53(20)$ & $\mathrm{NSC}^{\mathrm{c}}$ & 10 & 50 & Alent & 208 & NSC & NSC \\
\hline & & & & & & & & & & \\
\hline & Typical & $12.1(3)$ & $0.295(6)$ & NSC & 10 & 50 & Alert & 110 & NSC & NSC \\
\hline
\end{tabular}

a. Prolective action criteria are based on company guidelines for determining event classification. The definitions for event classifications of hazardous material releases at the INEL are discussed in the text.

b. The Alert protective action criteria value listed is the ERPG-1 value for phenol

c. The Site Area Emergency and General Emergency protective action criteria value listed is the ERPG-2 value for phenol.

d. The company guidelines for ERPGs and ERPG equivalents are discussed in the text. The ERPG-3 concentration of 250 ppm for phenol was used.

e. NSC stands for No Significant Consequences. The estimated airborne concentration was not significant at this receptor location or the ERPG (or equivalent) concentration was not exceeded at $100 \mathrm{~m}$. 
Table C-70. Summary of event consequences for a release of phenol $(4,540 \mathrm{~kg})$.

\begin{tabular}{|c|c|c|c|c|c|c|c|c|c|c|}
\hline \multirow[b]{2}{*}{ Release Type } & \multirow[b]{2}{*}{$\begin{array}{l}\text { Meteorological } \\
\text { conditions }\end{array}$} & \multicolumn{3}{|c|}{$\begin{array}{l}\begin{array}{l}\text { Peak concentration (time to) } \\
(\mathrm{ppm})\end{array} \quad(\mathrm{min})\end{array}$} & \multicolumn{2}{|c|}{$\begin{array}{l}\text { Protective action criteria" } \\
\text { (ppm) }\end{array}$} & \multirow{2}{*}{$\begin{array}{l}\text { Highest } \\
\text { emergency } \\
\text { class }\end{array}$} & \multicolumn{3}{|c|}{$\begin{array}{l}\text { Distance to ERPG or equivalent } \\
\qquad(\mathrm{m})\end{array}$} \\
\hline & & $100 \mathrm{~m}$ & $756 \mathrm{~m}$ & $5,200 \mathrm{~m}$ & Alert $^{b}$ & $\begin{array}{c}\text { Site Area or General } \\
\text { Emergency }{ }^{\circ}\end{array}$ & & $\begin{array}{l}\text { ERPG-1 or } \\
\text { equivalent }\end{array}$ & $\begin{array}{l}\text { ERPG-2 or } \\
\text { equivalent }\end{array}$ & $\begin{array}{l}\text { ERPG-3 or } \\
\text { equivalent }\end{array}$ \\
\hline \multirow{3}{*}{ Direct } & $95 \%$ worst-case & $391(5)$ & $13.2(25)$ & $\mathrm{NSC}^{\mathrm{e}}$ & 10 & 50 & Site Area & 900 & 325 & 123 \\
\hline & & & & & & & & & & \\
\hline & Typical & $193(3)$ & $603(6)$ & NSC & 10 & 50 & Site Area & 575 & 250 & NSC \\
\hline
\end{tabular}

a. Protective action criteria are based on company guidelines for determining event classification. The definitions for event classifications of hazardous material releases at the INEL are discussed in the text.

b. The Alert protective action criteria value listed is the ERPG-1 value for phenol.

c. The Site Area Emergency and General Emergency protective action criteria value listed is the ERPG-2 value for phenol.

d. The company guidelines for ERPGs and ERPG equivalents are discussed in the text. The ERPG-3 concentration of 250 ppm for phenol was used.

e. NSC stands for No Significant Consequences. The estimated airborne concentration was not significant at this receptor location or the ERPG (or equivalent) concentration was not exceeded at $100 \mathrm{~m}$. 
Table C-71. Summary of event consequences for a release of potassium permanganate.

\begin{tabular}{|c|c|c|c|c|c|c|c|c|c|c|}
\hline \multirow[b]{2}{*}{ Release Type } & \multirow[b]{2}{*}{$\begin{array}{l}\text { Meteorological } \\
\text { conditions }\end{array}$} & \multicolumn{3}{|c|}{$\begin{array}{l}\text { Peak concentration (time to) } \\
\qquad\left(\mathrm{mg} / \mathrm{m}^{3}\right)\end{array}$} & \multicolumn{2}{|c|}{$\begin{array}{l}\text { Protective action criteria } \\
\qquad\left(\mathrm{mg} / \mathrm{m}^{3}\right)\end{array}$} & \multirow{2}{*}{$\begin{array}{l}\text { Highest } \\
\text { emergency } \\
\text { class }\end{array}$} & \multicolumn{3}{|c|}{$\begin{array}{l}\text { Distance to ERPG or equivalent } \\
\text { (m) }\end{array}$} \\
\hline & & $100 \mathrm{~m}$ & $756 \mathrm{~m}$ & $5,200 \mathrm{~m}$ & Alert $^{b}$ & $\begin{array}{l}\text { Site Area or General } \\
\text { Emergency }^{c}\end{array}$ & & $\begin{array}{l}\text { ERPG-1 or } \\
\text { equivalent }\end{array}$ & $\begin{array}{l}\text { ERPG- } 2 \text { or } \\
\text { equivalent }\end{array}$ & $\begin{array}{l}\text { ERPG-3 or } \\
\text { equivalent }\end{array}$ \\
\hline \multirow{3}{*}{ Direct } & $95 \%$ worst-case & $81.1(3)$ & $1.74(20)$ & $\mathrm{NSC}^{\mathrm{e}}$ & 15 & 25 & Site Area & 238 & 183 & NLA \\
\hline & & & & & & & & & & \\
\hline & Typical & $4.5(2)$ & $\mathrm{NSC}$ & NSC & 15 & 25 & . & NSC & $\mathrm{NSC}$ & NLA \\
\hline
\end{tabular}

a. Protective action criteria are based on company guidelines for determining event classification. The definitions for event classifications of hazardous material releases at the INEL are discussed in the text.

b. The Alent protective action criteria value listed is the ERPG-1 equivalent ( $3 * \mathrm{PEL})$ value for potassium permanganate.

c. The Site Area Emergency and General Emergency protective action criteria value listed is the ERPG-2 equivalent ( $5^{*}$ PEL) value for potassium permanganate.

d. The company guidelines for ERPGs and ERPG equivalents are discussed in the text. There is no ERPG-3 or equivalent concentration for potassium permanganate.

e. NSC stands for No Significant Consequences. The estimated airborne concentration was not significant at this receptor location or the ERPG (or equivalent) concentration was not exceeded at $100 \mathrm{~m}$.

f. NLA stands for No Limit Available. NLA indicates that an ERPG or equivalent concentration limit was not available for the hazardous material. 

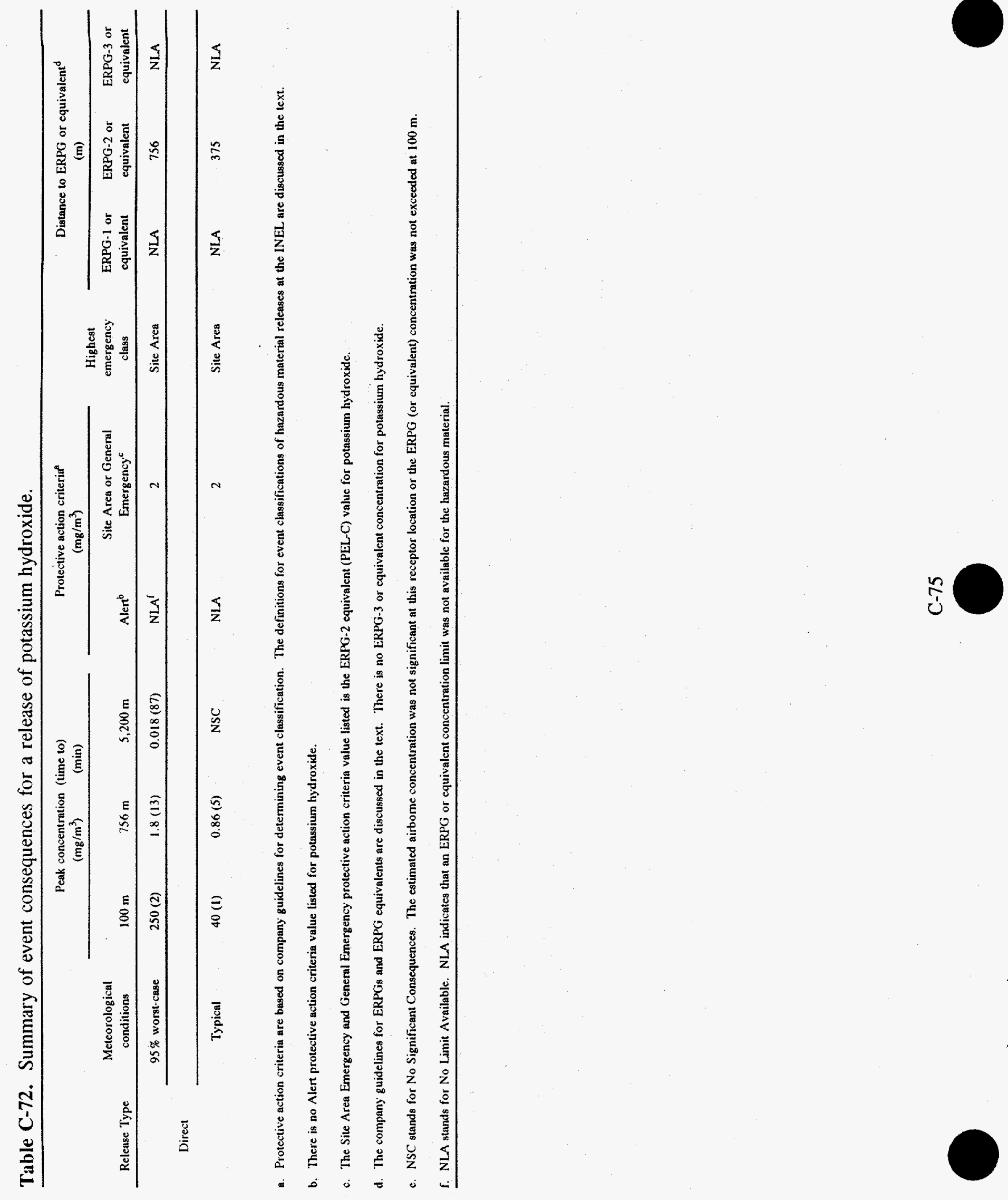
Table C-73. Summary of event consequences for a release of potassium chromate.

\begin{tabular}{|c|c|c|c|c|c|c|c|c|c|c|}
\hline \multirow[b]{2}{*}{ Release Type } & \multirow[b]{2}{*}{$\begin{array}{l}\text { Meteorological } \\
\text { conditions }\end{array}$} & \multicolumn{3}{|c|}{$\begin{array}{l}\text { Peak concentration (time to) } \\
\qquad\left(\mathrm{mg} / \mathrm{m}^{3}\right) \quad(\mathrm{min})\end{array}$} & \multicolumn{2}{|c|}{$\begin{array}{l}\text { Protective action criteria } \\
\qquad\left(\mathrm{mg} / \mathrm{m}^{3}\right)\end{array}$} & \multirow{2}{*}{$\begin{array}{c}\text { Highest } \\
\text { emergency } \\
\text { class }\end{array}$} & \multicolumn{3}{|c|}{$\begin{array}{l}\text { Distance to ERPG or equivalent } \\
\text { (m) }\end{array}$} \\
\hline & & $100 \mathrm{~m}$ & $756 \mathrm{~m}$ & $5,200 \mathrm{~m}$ & Alert $^{b}$ & $\begin{array}{l}\text { Site Area or General } \\
\text { Energency }{ }^{\circ}\end{array}$ & & $\begin{array}{l}\text { ERPG-1 or } \\
\text { equivalent }\end{array}$ & $\begin{array}{l}\text { ERPG-2 or } \\
\text { equivalent }\end{array}$ & $\begin{array}{l}\text { ERPG-3 or } \\
\text { equivalent }\end{array}$ \\
\hline \multirow{3}{*}{ Direct } & $95 \%$ worst-case & $8.11(4)$ & $0.17(20)$ & $\mathrm{NSC}^{e}$ & 0.3 & 0.5 & Site Area & 560 & 424 & NLA ${ }^{f}$ \\
\hline & & & & & & & & & & \\
\hline & Typical & $0.45(2)$ & NSC & NSC & 0.3 & 0.5 & Alert & 124 & NSC & NLA \\
\hline
\end{tabular}

a. Protective action criteria are based on company guidelines for determining event classification. The definitions for event classifications of hazardous material releases at the INEL are discussed in the text.

b. The Alen protective action criteria value listed is the ERPG-1 equivalent (3*PEL) value for potassium chromate.

c. The Site Area Emergency and General Emergency protective action criteria value listed is the ERPG-2 equivalent (5*PEL) value for potassium chromate.

d. The company guidelines for ERPGs and ERPG equivalents are discussed in the text. There is no ERPG-3 or equivalent concentration for potassium chromate.

e. NSC stands for No Significant Consequences. The estimated airborne concentration was not significant at this receptor location or the ERPG (or equivalent) concentration was not exceeded at $100 \mathrm{~m}$.

f. NLA stands for No Limit Available. NIA indicates that an ERPG or equivalent concentration limit was not available for the hazardous material. 
Table C-74. Summary of event consequences for a release of potassium.

\begin{tabular}{|c|c|c|c|c|c|c|c|c|c|c|}
\hline \multirow[b]{2}{*}{ Release Type } & \multirow[b]{2}{*}{$\begin{array}{l}\text { Meteorological } \\
\text { conditions }\end{array}$} & \multicolumn{3}{|c|}{$\begin{array}{l}\text { Peak concentration (time to) } \\
\qquad\left(\mathrm{mg} / \mathrm{m}^{3}\right) \quad(\mathrm{min})\end{array}$} & \multicolumn{2}{|c|}{$\begin{array}{l}\text { Protective action criteria } \\
\left(\mathbf{m g} / \mathbf{m}^{3}\right)\end{array}$} & \multirow{2}{*}{$\begin{array}{l}\text { Highest } \\
\text { emergency } \\
\text { class }\end{array}$} & \multicolumn{3}{|c|}{$\begin{array}{l}\text { Distance to ERPG or equivalent } \\
\qquad(\mathrm{m})\end{array}$} \\
\hline & & $100 \mathrm{~m}$ & $756 \mathrm{~m}$ & $5,200 \mathrm{~m}$ & Alert ${ }^{b}$ & $\begin{array}{l}\text { Site Area or General } \\
\text { Emergency }\end{array}$ & & $\begin{array}{l}\text { ERPG-1 or } \\
\text { equivalent }\end{array}$ & $\begin{array}{l}\text { ERPG-2 or } \\
\text { equivalent }\end{array}$ & $\begin{array}{l}\text { ERPG-3 or } \\
\text { equivalent }\end{array}$ \\
\hline \multirow{3}{*}{ Direat } & $95 \%$ worst-case & $0.38(4)$ & NSC & NSC & 30 & 50 & - & NSC & NSC & $N_{L A}{ }^{f}$ \\
\hline & & & & & & & & & & \\
\hline & Typical & $0.02(3)$ & NSC & NSC & 30 & 50 & . & NSC & NSC & NILA \\
\hline
\end{tabular}

a. Protective action critcria are based on company guidelines for determining event classification. The definitions for event classifications of hazardous material releases at the INEL are discussed in the text.

b. The Alen protective action criteria value listed is the ERPG-1 equivalent (estimated by WERF IH) value for potassium.

c. The Site Area Emergency and General Emergency protective action criteria value listed is the ERPG-2 equivalent (estimated by WERF IH) value for potassium.

d. The company guidelines for ERPGs and ERPG equivalents are discussed in the text. There is no ERPG-3 or equivalent concentration for potassium.

e. NSC stands for No Significant Consequences. The estimated airborne concentration was not significant at this receptor location or the ERPG (or equivalent) concentration was not exceeded at $100 \mathrm{~m}$.

f. NLA stands for No Limit Available. NLA indicates that an ERPG or equivalent concentration limit was not available for the hazardous material 
Table C-75. Summary of event consequences for a release of pyrene.

\begin{tabular}{|c|c|c|c|c|c|c|c|c|c|c|}
\hline \multirow[b]{2}{*}{ Release Type } & \multirow[b]{2}{*}{$\begin{array}{l}\text { Meteorological } \\
\text { conditions }\end{array}$} & \multicolumn{3}{|c|}{$\begin{array}{cc}\begin{array}{c}\text { Peak concentration } \\
(\text { time to) } \\
\left(\mathrm{mp} / \mathrm{m}^{3}\right)\end{array} \quad(\mathrm{min}) \\
\end{array}$} & \multicolumn{2}{|c|}{$\begin{array}{c}\text { Protective action criteria } \\
\left(\mathrm{mg} / \mathrm{m}^{3}\right)\end{array}$} & \multirow{2}{*}{$\begin{array}{c}\text { Highest } \\
\text { emergency } \\
\text { class }\end{array}$} & \multicolumn{3}{|c|}{$\begin{array}{l}\text { Distance to ERPG or equivalent }{ }^{d} \\
\qquad(\mathrm{~m})\end{array}$} \\
\hline & & $100 \mathrm{~m}$ & $756 \mathrm{~m}$ & $5,200 \mathrm{~m}$ & Aler $^{b}$ & $\begin{array}{l}\text { Site Area or General } \\
\text { Emergency }{ }^{c}\end{array}$ & & $\begin{array}{l}\text { ERPG-1 or } \\
\text { equivalent }\end{array}$ & $\begin{array}{l}\text { ERPG-2 or } \\
\text { equivalent }\end{array}$ & $\begin{array}{l}\text { ERPG-3 or } \\
\text { equivalent }\end{array}$ \\
\hline \multirow{3}{*}{ Direct } & $95 \%$ worst-case & $193(6)$ & $9.23(24)$ & $\mathrm{NSC}^{\mathrm{e}}$ & 0.6 & 1 & Site Area & 3,200 & 2,900 & $N \perp A^{f}$ \\
\hline & & & & & & & & & & \\
\hline & Typical & $96.3(4)$ & $2.31(7)$ & NSC & 0.6 & 1 & Sile Area & 1,500 & 1,200 & NLA \\
\hline
\end{tabular}

a. Protective action criteria are based on company guidelines for determining event classification. The definitions for event classifications of hazardous material releases at the INEL are discussed in the text.

b. The Alert protective action criteria value listed is the ERPG-1 equivalent ( 3 *PEL) value for pyrene.

c. The Site Area Emergency and General Emergency protective action criteria value listed is the ERPG-2 equivalent (5*PEL) value for pyrene.

d. The company guidelines for ERPGs and ERPG equivalents are discussed in the text. There is no ERPG-3 or equivalent concentration for pyrene.

e. NSC stands for No Significant Consequences. The estimated airborne concentration was not significant at this receptor location or the ERPG (or equivalent) concentration was not exceeded at $100 \mathrm{~m}$.

f. NLA stands for No Limit Available. NLA indicates that an ERPG or equivalent concentration limit was not available for the hazardous material. 
Table C-76. Summary of event consequences for a release of pyridine.

\begin{tabular}{|c|c|c|c|c|c|c|c|c|c|c|}
\hline \multirow[b]{2}{*}{ Release Type } & \multirow[b]{2}{*}{$\begin{array}{l}\text { Meteorological } \\
\text { conditions }\end{array}$} & \multicolumn{3}{|c|}{$\begin{array}{l}\text { Peak concentration (time to) } \\
\qquad \begin{array}{l}(\mathrm{ppm}) \\
(\mathrm{min})\end{array}\end{array}$} & \multicolumn{2}{|c|}{$\begin{array}{l}\text { Protective action criteria } \\
\text { (ppm) }\end{array}$} & \multirow{2}{*}{$\begin{array}{l}\text { Highest } \\
\text { emergency } \\
\text { class }\end{array}$} & \multicolumn{3}{|c|}{$\begin{array}{l}\text { Distance to ERPG or equivalent } \\
\qquad(\mathrm{m})\end{array}$} \\
\hline & & $100 \mathrm{~m}$ & $756 \mathrm{~m}$ & $5,200 \mathrm{~m}$ & Alert $^{b}$ & $\begin{array}{l}\text { Site Area or General } \\
\text { Emergency }{ }^{\circ}\end{array}$ & & $\begin{array}{l}\text { ERPG-1 or } \\
\text { equivalent }\end{array}$ & $\begin{array}{l}\text { ERPG- } 2 \text { or } \\
\text { equivalent }\end{array}$ & $\begin{array}{l}\text { ERPG-3 or } \\
\text { equivalent }\end{array}$ \\
\hline & $95 \%$ worst-cuse & $64.6(5)$ & $3.05(21)$ & $\mathrm{NSC}^{\mathrm{e}}$ & 15 & 25 & Site Area & 260 & 185 & NSC \\
\hline \multicolumn{11}{|l|}{ Direct } \\
\hline & Typical & $32.7(3)$ & $0.713(7)$ & NSC & 15 & 25 & Site Area & 150 & 115 & NSC \\
\hline & $95 \%$ worst-case & $29(3)$ & $0.644(20)$ & NSC & 15 & 25 & Site Area & 141 & 108 & NSC \\
\hline \multicolumn{11}{|l|}{ Spill } \\
\hline & Typical & $2.89(1)$ & $\mathrm{NSC}$ & NSC & 15 & 25 & - & NSC & NSC & NSC \\
\hline \multirow{3}{*}{ Spill w/ fire } & $95 \%$ worst-case & $279(7)$ & $10.4(22)$ & $\mathrm{NSC}$ & 15 & 25 & Site Area & 600 & 440 & NSC \\
\hline & & & & - & & & & & & \\
\hline & Typical & $295(5)$ & $8.03(8)$ & NSC & 15 & 25 & Site Area & 530 & 400 & NSC \\
\hline
\end{tabular}

a. Protective action criteria are based on company guidelines for determining event classification. The definitions for event classifications of hazardous material releases at the INEL are discussed in the text.

b. The Alert protective action criteria value listed is the ERPG-1 equivalent (TLV-STEL) value for pyridine.

c. The Site Area Emergency and General Emergency protective action criteria value listed is the ERPG-2 equivalent (5*TLV-TWA) value for pyridine.

d. The company guidelines for ERPGs and ERPG equivalents are discussed in the text. The ERPG-3 equivalent (IDLH) concentration of 3,600 ppm for pyridine was used.

e. NSC stands for No Significant Consequences. The estimated airbome concentration was not significant at this receptor location or the ERPG (or equivalent) concentration was not exceeded at $100 \mathrm{~m}$. 
Table C-77. Summary of event consequences for a release of selenium.

\begin{tabular}{|c|c|c|c|c|c|c|c|c|c|c|}
\hline \multirow[b]{2}{*}{ Release Type } & \multirow[b]{2}{*}{$\begin{array}{l}\text { Meteorological } \\
\text { conditions }\end{array}$} & \multicolumn{3}{|c|}{$\begin{array}{l}\text { Peak concentration (time to) } \\
\left(\mathrm{mg} / \mathrm{m}^{3}\right) \quad(\mathrm{min})\end{array}$} & \multicolumn{2}{|c|}{$\begin{array}{l}\text { Protective action criteria }{ }^{8} \\
\left(\mathrm{mg} / \mathrm{m}^{3}\right)\end{array}$} & \multirow{2}{*}{$\begin{array}{c}\text { Highest } \\
\text { emergency } \\
\text { class }\end{array}$} & \multicolumn{3}{|c|}{$\begin{array}{l}\text { Distance to ERPG or equivalent } \\
(\mathrm{m})\end{array}$} \\
\hline & & $100 \mathrm{~m}$ & $756 \mathrm{~m}$ & $5.200 \mathrm{~m}$ & Alen ${ }^{b}$ & $\begin{array}{l}\text { Site Area or General } \\
\text { Emergency }\end{array}$ & & $\begin{array}{l}\text { ERPG-1 or } \\
\text { equivalent }\end{array}$ & $\begin{array}{l}\text { ERPG-2 or } \\
\text { equivalent }\end{array}$ & $\begin{array}{l}\text { ERPG-3 or } \\
\text { equivalent }\end{array}$ \\
\hline \multirow{3}{*}{ Direct } & $95 \%$ worbl-case & $25(2)$ & $0.18(13)$ & $\mathrm{NSC}^{c}$ & 0.6 & 1 & Site Arca & 460 & 370 & NLA $f$ \\
\hline & & & & & & & & & & \\
\hline & Typical & $4.0(1)$ & $0.086(5)$ & NSC & 0.6 & 1 & Site Aren & 260 & 200 & NLA \\
\hline
\end{tabular}

a. Protective action criteria are based on company guidelines for determining event classification. The definitions for event classifications of hazardous material releases at the INEL are discussed in the text.

b. The Alert protective action criteria value listed is the ERPG-1 equivalent (3*TLV-TWA) value for selenium.

c. The Site Area Emergency and General Emergency protective action criteria value listed is the ERPG-2 equivalent (5*TLV-TWA) value for selenium.

d. The company guidelines for ERPGs and ERPG equivalents are discussed in the text. There is no ERPG-3 or equivalent concentration for seleniurn.

e. NSC stands for No Significan Consequences. The estimsted airborne concentration was not significant at this receptor location or the ERPG (or equivalent) concentration was not exceeded at $100 \mathrm{~m}$.

f. NLA stunds for No Limit Available. NLA indicates that an ERPG or equivalent concentration limit was not available for the hazardous material. 
Table C-78. Summary of event consequences for a release of soluble silver.

\begin{tabular}{|c|c|c|c|c|c|c|c|c|c|c|}
\hline \multirow[b]{2}{*}{ Release Type } & \multirow[b]{2}{*}{$\begin{array}{l}\text { Meteoralogical } \\
\text { conditions }\end{array}$} & \multicolumn{3}{|c|}{$\begin{array}{cc}\begin{array}{c}\text { Peak concentration (time to) } \\
\left(\mathrm{mg} / \mathrm{m}^{3}\right) \\
(\mathrm{min})\end{array} \\
\end{array}$} & \multicolumn{2}{|c|}{$\begin{array}{l}\text { Protective action criteria" } \\
\left(\mathrm{mg} / \mathrm{m}^{3}\right)\end{array}$} & \multirow{2}{*}{$\begin{array}{l}\text { Higheat } \\
\text { emergency } \\
\text { class }\end{array}$} & \multicolumn{3}{|c|}{$\begin{array}{l}\text { Distance to ERPG or equivalent } \\
\text { (m) }\end{array}$} \\
\hline & & $100 \mathrm{~m}$ & $756 \mathrm{~m}$ & $5,200 \mathrm{~m}$ & Alert $^{\mathrm{b}}$ & $\begin{array}{l}\text { Site Area or General } \\
\text { Emergency }{ }^{c}\end{array}$ & & $\begin{array}{l}\text { ERPG-1 or } \\
\text { equivalent }\end{array}$ & $\begin{array}{l}\text { ERPG- } 2 \text { or } \\
\text { equivalent }\end{array}$ & $\begin{array}{l}\text { ERPG-3 or } \\
\text { equivalent }\end{array}$ \\
\hline & $95 \%$ worst-case & $250(2)$ & $1.8(13)$ & $0.018(87)$ & 0.03 & 0.05 & Site Area & 4,100 & 3,300 & NLA ${ }^{f}$ \\
\hline \multicolumn{11}{|l|}{ Direct } \\
\hline & Typical & $40(1)$ & $0.86(5)$ & NSC & 0.03 & 0.05 & Site Area & 5.800 & 4,100 & NLA \\
\hline
\end{tabular}

a. Protective action criteria are based on company guidelines for determining event classification. The definitions for event classifications of hazardous material releases at the INEL are discusad in the text.

b. The Alert protective action criteria value listed is the ERPG-1 equivalent (3*TLV-TWA) value for soluble silver.

c. The Site Area Emergency and General Emergency protective action criteria value listed is the ERPG-2 equivalent (5*TLV-TWA) value for soluble silver.

d. The company guidelines for ERPGs and ERPG equivalents are diecussed in the text. There is no ERPG-3 or equivalent concentration for soluble silver.

e. NSC stands for No Significant Consequences. The extimated airborne concentration was not significant at this receptor location or the ERPG (or equivalent) concentration was not exceeded at I00 m.

f. NLA stands for No Limit Available. NLA indicates that an ERPG or equivalent concentration limit was not avaikble for the hazardous material. 

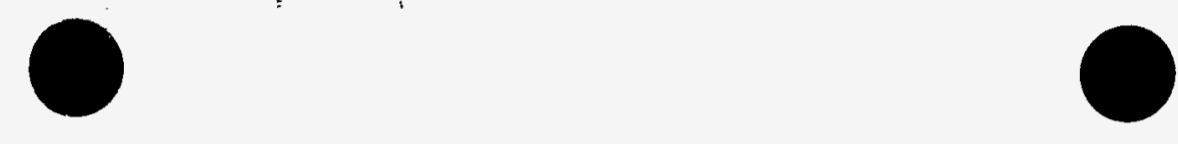

Table C-79. Summary of event consequences for a release of silvex $(2,4,5-\mathrm{TP})$.

\begin{tabular}{|c|c|c|c|c|c|c|c|c|c|c|}
\hline \multirow[b]{2}{*}{ Release Type } & \multirow[b]{2}{*}{$\begin{array}{c}\text { Meteorological } \\
\text { conditions }\end{array}$} & \multicolumn{3}{|c|}{$\begin{array}{c}\begin{array}{c}\text { Peak concentration (time to) } \\
(\mathrm{ppm}) \quad(\mathrm{min})\end{array}\end{array}$} & \multicolumn{2}{|c|}{$\begin{array}{l}\text { Protective action criteria" } \\
\text { (ppm) }\end{array}$} & \multirow{2}{*}{$\begin{array}{c}\text { Highear } \\
\text { emergency } \\
\text { elase }\end{array}$} & \multicolumn{3}{|c|}{$\begin{array}{c}\text { Distance to ERPG or equivalents } \\
\text { (m) }\end{array}$} \\
\hline & & $100 \mathrm{~m}$ & $756 \mathrm{~m}$ & $5,200 \mathrm{~m}$ & Alert ${ }^{b}$ & $\begin{array}{c}\text { Site Area or General } \\
\text { Emergency }\end{array}$ & & $\begin{array}{l}\text { ERPG-1 or } \\
\text { equivalent } \\
\end{array}$ & $\begin{array}{l}\text { ERPG-2 or } \\
\text { equivalent }\end{array}$ & $\begin{array}{l}\text { ERPG-3 or } \\
\text { equivalent }\end{array}$ \\
\hline & $95 \%$ worst-case & $7.24(4)$ & $0.16(23)$ & $\mathrm{NSC}^{*}$ & 0.3 & 0.5 & Site Area & 526 & 400 & $\mathrm{NLA}^{\mathrm{f}}$ \\
\hline \multicolumn{11}{|l|}{ Direct } \\
\hline & Typical & $0.402(2)$ & NSC & NSC & 0.3 & 0.5 & Alert & 116 & NSC & NLA \\
\hline
\end{tabular}

a. Protective action critcria are besed on company guidelines for determining event classification. The definitions for event classifications of hazardous material releasca at the INEL are discuseod in the text.

b. The Alert protective action criteris value listed is the ERPG-1 equivalent (eatimated by WERF IH) value for silvex (2,4,5-TP)

c. The Sive Area Emergency and General Emergency protective action criteria value listed is the ERPG.2 equivalent (estimated by WERF IH) value for silvex (2,4,5-TP).

d. The company guidelines for ERPGs and ERPG equivalents ere discussed in the text. There is no ERPG-3 or equivalent concentration for silvex (2,4,5-TP).

e. NSC stands for No Significant Consequences. The estimated airborne concentration was not significant at this receptor location or the ERPG (or equivalent) concentration was not exceoded at $100 \mathrm{~m}$.

f. NLA atands for No Limit Available. NLA indicates that an ERPG or equivalent concentration limit was not available for the hazardous material. 
Table C-80. Summary of event consequences for a release of sodium fluoride.

\begin{tabular}{|c|c|c|c|c|c|c|c|c|c|c|}
\hline \multirow[b]{2}{*}{ Relense Type } & \multirow[b]{2}{*}{$\begin{array}{c}\text { Meteorological } \\
\text { conditions } \\
\end{array}$} & \multicolumn{3}{|c|}{ 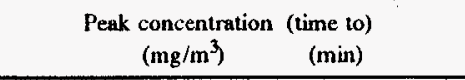 } & \multicolumn{2}{|c|}{$\begin{array}{c}\text { Protective action criteriaa } \\
\left(\mathrm{mg} / \mathrm{m}^{3}\right)\end{array}$} & \multirow{2}{*}{$\begin{array}{c}\text { Highest } \\
\text { emergency } \\
\text { class }\end{array}$} & \multicolumn{3}{|c|}{$\begin{array}{l}\text { Distance to ERPG or equivalent } \\
\text { (m) }\end{array}$} \\
\hline & & $100 \mathrm{~m}$ & $756 \mathrm{~m}$ & $5,200 \mathrm{~m}$ & Alent ${ }^{b}$ & $\begin{array}{l}\text { Site Area or General } \\
\text { Emergency }^{c}\end{array}$ & & $\begin{array}{l}\text { ERPG-1 or } \\
\text { equivalent }\end{array}$ & $\begin{array}{l}\text { ERPG- } 2 \text { or } \\
\text { equivatent }\end{array}$ & $\begin{array}{l}\text { ERPG-3 or } \\
\text { equivalent }\end{array}$ \\
\hline \multirow{3}{*}{ Direct } & $95 \%$ worst-case & $24 !(5)$ & 11,3 & $\mathrm{NSC}^{e}$ & 7.5 & 12.5 & Site Area & 940 & 700 & $\mathrm{NLA}^{f}$ \\
\hline & & & & & & & & & & \\
\hline & Typical & $97.2(3)$ & NSC & NSC & 7.5 & 12.5 & Site Area & 400 & 303 & NLA \\
\hline
\end{tabular}

a. Protective action criteria are based on company guidelines for determining event clussification. The definitions for event classifications of hazardous material releases at the INEL are discussed in the text.

b. The Alert protective action criteria value listed is the ERPG-1 equivalent (3*PEL) value for sodium fluoride.

c. The Site Area Emergency and General Emergency protective action criteria value listed is the ERPG-2 equivalent (5*PEL) value for sodium fluoride.

d. The company guidelines for ERPGs and ERPG equivalents are discussed in the text. There is no ERPG-3 or equivalent concentration for sodium fluoride.

e. NSC stands for No Significant Consequences. The estimated airbome concentration was not significant at this receptor location or the ERPG (or equivalent) concentration was not exceeded at $100 \mathrm{~m}$

f. NLA stands for No Limit Available. NLA indicates that an ERPG or equivalent concentration limit was not available for the hazardous material. 

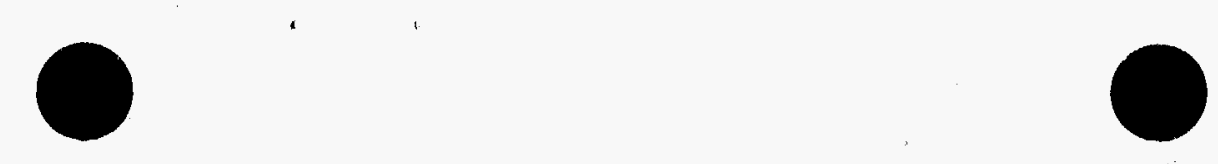

Table C-81. Summary of event consequences for a release of sodium.

\begin{tabular}{|c|c|c|c|c|c|c|c|c|c|c|}
\hline \multirow[b]{2}{*}{ Release Type } & \multirow[b]{2}{*}{$\begin{array}{c}\text { Meteorological } \\
\text { conditions }\end{array}$} & \multicolumn{3}{|c|}{$\begin{array}{l}\text { Peak concentration (time to) } \\
\qquad\left(\mathrm{mg} / \mathrm{m}^{3}\right) \\
(\mathrm{min})\end{array}$} & \multicolumn{2}{|c|}{$\begin{array}{l}\text { Protective action criteriag } \\
\left(\mathrm{mg} / \mathrm{m}^{3}\right)\end{array}$} & \multirow{2}{*}{$\begin{array}{l}\text { Highest } \\
\text { emergency } \\
\text { class }\end{array}$} & \multicolumn{3}{|c|}{$\begin{array}{l}\text { Distance to ERPG or equivalent }{ }^{d} \\
\text { (m) }\end{array}$} \\
\hline & & $100 \mathrm{~m}$ & $756 \mathrm{~m}$ & $5,200 \mathrm{~m}$ & Aler ${ }^{b}$ & $\begin{array}{l}\text { Site Area or General } \\
\text { Emergency }{ }^{c}\end{array}$ & & $\begin{array}{l}\text { ERPG-1 or } \\
\text { equivalent }\end{array}$ & $\begin{array}{l}\text { ERPG-2 or } \\
\text { equivalent }\end{array}$ & $\begin{array}{l}\text { ERPG-3 or } \\
\text { equivalent }\end{array}$ \\
\hline \multirow{3}{*}{ Direct } & $95 \%$ worst-case & $8.11(4)$ & $\mathrm{NSC}^{\mathrm{c}}$ & NSC & 30 & 50 & - & NSC & NSC & NLA \\
\hline & & & & & & & & & & \\
\hline & Typical & $0.45(3)$ & NSC & NSC & 30 & so & - & NSC & NSC & NLA \\
\hline
\end{tabular}

a. Protective action criteria are based on company guidelines for determining event classification. The definitions for event classifications of hazardous material releases at the INEL are discussed in the text.

b. The Alert protective action criteria value listed is the ERPG-1 equivalent (estimated by WERF IH) value for sodiun.

c. The Site Area Emergency and General Emergency protective action criteria value listed is the ERPG-2 equivalent (estimated by WERF IH) value for sodium.

d. The company guidelines for ERPGs and ERPG equivalents are discussed in the text. There is no ERPG-3 or equivalent concentration for sodium.

e. NSC stands for No Significant Consequences. The estimated airborne concentration was not significant at this receptor location or the ERPG (or equivalent) concentration was not exceeded at $100 \mathrm{~m}$.

f. NLA stands for No Limit Available. NLA indicates that an ERPG or equivalent concentration limit was not available for the hazardous material. 
Table C-82. Summary of event consequences for a release of sulfuric acid.

\begin{tabular}{|c|c|c|c|c|c|c|c|c|c|c|}
\hline \multirow[b]{2}{*}{ Release Type } & \multirow[b]{2}{*}{$\begin{array}{l}\text { Meteorological } \\
\text { conditions }\end{array}$} & \multicolumn{3}{|c|}{$\begin{array}{l}\begin{array}{l}\text { Peak concentration, (time to) } \\
\left(\mathrm{mg} / \mathrm{m}^{3}\right) \\
(\mathrm{min})\end{array}\end{array}$} & \multicolumn{2}{|c|}{$\begin{array}{l}\text { Protective action criteria } \\
\left(\mathrm{mp} / \mathrm{m}^{3}\right)\end{array}$} & \multirow{2}{*}{$\begin{array}{c}\text { Highest } \\
\text { emergency } \\
\text { class }\end{array}$} & \multicolumn{3}{|c|}{$\begin{array}{l}\text { Distance to ERPG or equivalent } \\
(\mathrm{m})\end{array}$} \\
\hline & & $100 \mathrm{~m}$ & $756 \mathrm{~m}$ & $5,200 \mathrm{~m}$ & Alert" & $\begin{array}{l}\text { Site Area or General } \\
\text { Emergency }{ }^{c}\end{array}$ & & $\begin{array}{l}\text { ERPG-1 or } \\
\text { equivalent }\end{array}$ & $\begin{array}{l}\text { ERPG-2 or } \\
\text { equivalent }\end{array}$ & $\begin{array}{l}\text { ERPG-3 or } \\
\text { equivalent }\end{array}$ \\
\hline & $95 \%$ worst-case & $720(2)$ & $14(13)$ & $\mathrm{NSC}^{e}$ & 2 & 10 & Site Area & 2,300 & 900 & 500 \\
\hline \multicolumn{11}{|l|}{ Direct } \\
\hline & Typical & $45(1)$ & $1.1(5)$ & NSC & 2 & 10 & Site Area & 530 & 225 & 125 \\
\hline & $95 \%$ worst-case & $8.9 \mathrm{E}-7(2)$ & NSC & NSC & 2 & 10 & - & NSC & NSC & NSC \\
\hline \multicolumn{11}{|l|}{ Spill } \\
\hline & Typical & $6.4 \mathrm{E}-8(1)$ & $\mathrm{NSC}$ & NSC & 2 & 10 & . & NSC & NSC & NSC \\
\hline & $95 \%$ worst-case & $4.9 \mathrm{E}-3(2)$ & NSC & NSC & 2 & 10 & - & NSC & $\mathrm{NSC}$ & NSC \\
\hline \multicolumn{11}{|l|}{ Spill $w /$ fire } \\
\hline & Typical & $3.5 \mathrm{E}-4(1)$ & NSC & NSC & 2 & 10 & & $\mathrm{NSC}$ & NSC & NSC \\
\hline
\end{tabular}

a. Protective action criteria are based on company guidelines for detemining event classification. The definitions for event classifications of hazardous material releases at the INEL are discussed in the text.

b. The Alert protective action criteria value listed is the ERPG-1 value for sulfuric acid.

c. The Site Area Emergency and General Emergency protective action criteria value listed is the ERPG-2 value for sulfuric acid.

d. The company guidelines for ERPGs and ERPG equivalents are discussed in the text. The ERPG-3 concentration of $30 \mathrm{mg} / \mathrm{m}^{3}$ for sulfuric acid was used.

e. NSC stands for No Significant Consequences. The estimated airborne concentration was not significant at this receptor location or the ERPG (or equivalent) concentration was not exceeded at $100 \mathrm{~m}$. 
Table C-83. Summary of event consequences for a release of tetrachloroethene.

\begin{tabular}{|c|c|c|c|c|c|c|c|c|c|c|}
\hline \multirow[b]{2}{*}{ Release Type } & \multirow[b]{2}{*}{$\begin{array}{l}\text { Meteorological } \\
\text { conditions }\end{array}$} & \multicolumn{3}{|c|}{$\begin{array}{l}\text { Peak concentration (time to) } \\
\begin{array}{c}(\mathrm{ppm}) \quad(\mathrm{min})\end{array}\end{array}$} & \multicolumn{2}{|c|}{$\begin{array}{l}\text { Protective action criterian } \\
\qquad(\mathrm{ppm})\end{array}$} & \multirow{2}{*}{$\begin{array}{c}\begin{array}{c}\text { Highest } \\
\text { emergency } \\
\text { class }\end{array} \\
\end{array}$} & \multicolumn{3}{|c|}{$\begin{array}{l}\text { Distance to ERPG or equivalent } \\
(\mathrm{m})\end{array}$} \\
\hline & & $100 \mathrm{~m}$ & $756 \mathrm{~m}$ & $5,200 \mathrm{~m}$ & Alert ${ }^{b}$ & $\begin{array}{l}\text { Site Area or General } \\
\text { Emergency }^{c}\end{array}$ & & $\begin{array}{l}\text { ERPG-1 or } \\
\text { equivalent }\end{array}$ & $\begin{array}{l}\text { ERPG-2 or } \\
\text { equivalent }\end{array}$ & $\begin{array}{l}\text { ERPG } 3 \text { or } \\
\text { equivatent }\end{array}$ \\
\hline & $95 \%$ worst-case & $11(2)$ & $0.21(13)$ & $\mathrm{NSC}^{+}$ & 100 & 200 & - & $\mathrm{NSC}$ & NSC & $\mathrm{NSC}$ \\
\hline \multicolumn{11}{|l|}{ Direct } \\
\hline & Typical & $0.66(1)$ & NSC & NSC & 100 & 200 & - & NSC & NSC & NSC \\
\hline & $95 \%$ worst-case & $6.4(2)$ & NSC & NSC & 100 & 200 & - & NSC & NSC & $\mathrm{NSC}$ \\
\hline \multicolumn{11}{|l|}{ Spill } \\
\hline & Typical & $0.46(1)$ & NSC & NSC & 100 & 200 & - & NSC & NSC & NSC \\
\hline \multirow{3}{*}{ Spill w/ fire } & $95 \%$ worst-case & $77(2)$ & $2.0(13)$ & NSC & 100 & 200 & - & NSC & NSC & NSC \\
\hline & & & & & & & & & & \\
\hline & Typical & $5.5(1)$ & NSC & NSC & 100 & 200 & - & NSC & NSC & NSC \\
\hline
\end{tabular}

a. Protective action criteria are based on company guidelines for determining event classification. The definitions for event classifications of hazardous material releases at the INEL are discussed in the text

b. The Alen protective action criteria value listed is the ERPG-1 value for tetrachloroethene.

c. The Site Area Emergency and General Emergency protective action criteria value listed is the ERPG-2 value for tetrachloroethene.

d. The company guidelines for ERPGs and ERPG equivalents are discussed in the text. The ERPG-3 concentration of 500 ppm for tetrachloroethene was used.

e. NSC stands for No Significant Consequences. The estimated airborne concentration was not significant at this receptor location or the ERPG (or equivalent) concentration was not exceeded at $100 \mathrm{~m}$. 
Table C-84. Summary of event consequences for a release of tetrachloroethylene.

\begin{tabular}{|c|c|c|c|c|c|c|c|c|c|c|}
\hline \multirow[b]{2}{*}{ Release Type } & \multirow[b]{2}{*}{$\begin{array}{l}\text { Meteorological } \\
\text { conditions }\end{array}$} & \multicolumn{3}{|c|}{$\begin{array}{l}\text { Peak concentration (time to) } \\
\begin{array}{c}(\mathrm{ppm}) \\
(\mathrm{min})\end{array}\end{array}$} & \multicolumn{2}{|c|}{$\begin{array}{l}\text { Protective action criteria } \\
\text { (ppm) }\end{array}$} & \multirow{2}{*}{$\begin{array}{c}\text { Highest } \\
\text { emergency } \\
\text { class }\end{array}$} & \multicolumn{3}{|c|}{$\begin{array}{l}\text { Distance to ERPG or equivalent } \\
\qquad(\mathrm{m})\end{array}$} \\
\hline & & $100 \mathrm{~m}$ & $756 \mathrm{~m}$ & $5,200 \mathrm{~m}$ & Aler $^{b}$ & $\begin{array}{l}\text { Site Area or General } \\
\text { Emergencyc }\end{array}$ & & $\begin{array}{l}\text { ERPG-1 or } \\
\text { equivalent }\end{array}$ & $\begin{array}{l}\text { ERPG-2 or } \\
\text { equivalent }\end{array}$ & $\begin{array}{l}\text { ERPG-3 or } \\
\text { equivalent }\end{array}$ \\
\hline & $95 \%$ worst-case & $4.92(5)$ & $\mathrm{NSC}^{\mathrm{c}}$ & NSC & 100 & 200 & - & NSC & NSC & NSC \\
\hline \multicolumn{11}{|l|}{ Direut } \\
\hline & Typical & $1.48(4)$ & NSC & NSC & 100 & 200 & - & NSC & NSC & $\mathrm{NSC}$ \\
\hline & $95 \%$ worst-case & $7.73(8)$ & NSC & NSC & 100 & 200 & - & NSC & NSC & NSC \\
\hline \multicolumn{11}{|l|}{ Spill } \\
\hline & Typical & $1.57(3)$ & NSC & NSC & 100 & 200 & - & NSC & NSC & NSC \\
\hline \multirow{3}{*}{ Spill w/ fire } & $95 \%$ worst-case & $133(18)$ & NSC & NSC & 100 & 200 & Alent & 120 & NSC & NSC \\
\hline & & & & & & & & & & \\
\hline & Typical & $74.9(4)$ & NSC & NSC & 100 & 200 & - & NSC & NSC & NSC \\
\hline
\end{tabular}

a. Protective action criteria are based on company guidelines for determining event classification. The definitions for event classifications of hazardous material releases at the INEL are discussed in the text.

b. The Alert protective action criteria value listed is the draft ERPG-1 value for tetrachloroethylene.

c. The Site Area Emergency and General Emergency protective action criteria value listed is the draft ERPG-2 value for tetrachloroethylene

d. The company guidelines for ERPGs and ERPG equivalents are discussed in the text. The draft ERPG-3 concentration of 500 ppm for tetrachloroethylene was used.

e. NSC. stands for No Significant Consequences. The estimated airborne concentration was not significant at this receptor location or the ERPG (or equivalent) concentration was not exceeded at $100 \mathrm{~m}$. 


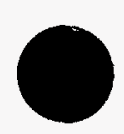

Table C-85. Summary of event consequences for a release of toluene.

\begin{tabular}{|c|c|c|c|c|c|c|c|c|c|c|}
\hline \multirow[b]{2}{*}{ Release Type } & \multirow[b]{2}{*}{$\begin{array}{l}\text { Meteorological } \\
\text { conditions }\end{array}$} & \multicolumn{3}{|c|}{$\begin{array}{cc}\begin{array}{c}\text { Peak concentration (time to) } \\
(\mathrm{ppm})\end{array} \quad(\mathrm{min}) \\
\end{array}$} & \multicolumn{2}{|c|}{$\begin{array}{l}\text { Protective action criteriaa } \\
\text { (ppm) }\end{array}$} & \multirow{2}{*}{$\begin{array}{c}\text { Highest } \\
\text { emergency } \\
\text { class }\end{array}$} & \multicolumn{3}{|c|}{$\begin{array}{l}\text { Distance to ERPG or equivalent } \\
\text { (m) }\end{array}$} \\
\hline & & $100 \mathrm{~m}$ & $756 \mathrm{~m}$ & $5,200 \mathrm{~m}$ & Aler $^{b}$ & $\begin{array}{l}\text { Site Area or General } \\
\text { Emergency }{ }^{c}\end{array}$ & & $\begin{array}{r}\text { ERPG-1 or } \\
\text { equivalent }\end{array}$ & $\begin{array}{l}\text { ERPG- } 2 \text { or } \\
\text { equivalent }\end{array}$ & $\begin{array}{l}\text { ERPG-3 or } \\
\text { equivalent }\end{array}$ \\
\hline & $95 \%$ worst-case & $54.3(4)$ & $\mathrm{NSC}^{e}$ & NSC & 150 & 250 & . & NSC & NSC & NSC \\
\hline \multicolumn{11}{|l|}{ Direct } \\
\hline & Typical & $25(3)$ & NSC & NSC & 150 & 250 & - & NSC & $\mathrm{NSC}$ & NSC \\
\hline & $95 \%$ worst-case & $15.6(3)$ & NSC & NSC & 150 & 250 & . & NSC & NSC & NSC \\
\hline \multicolumn{11}{|l|}{ Spill } \\
\hline & Typical & $3.81(1)$ & NSC & NSC & 150 & 250 & - & NSC & NSC & NSC \\
\hline \multirow{3}{*}{ Spill w/ fire } & $95 \%$ worst-case & $359(5)$ & $10.9(20)$ & NSC & 150 & 250 & Site Area & 162 & 123 & NSC \\
\hline & & & & & & & & & & \\
\hline & Typical & $327(4)$ & NSC & NSC & 150 & 250 & Site Area & 164 & 120 & NSC \\
\hline
\end{tabular}

a. Protective action criteria are based on company guidelines for determining event classification. The definitions for event classifications of hazardous material releases at the INEL are discussod in the text.

b. The Alen protective action criteria value listed is the ERPG-1 equivalent (3*TLV-TWA) value for toluene.

c. The Site Area Emergency and General Emergency protective action criteria value listed is the ERPG-2 equivalent (5*TLV-TWA) value for toluene.

d. The company guidelines for ERPGs and ERPG equivalents are discussed in the text. The ERPG-3 equivalent (IDLH) concentration of 2,000 ppm for toluene was used.

e. NSC stands for No Significant Consequences. The estimated airborne concentration was not significant at this receptor location or the ERPG (or equivalent) concentration was not exceeded at $100 \mathrm{~m}$ 
Table C-86. Summary of event consequences for a release of toxaphene $(227 \mathrm{~kg})$.

\begin{tabular}{|c|c|c|c|c|c|c|c|c|c|c|}
\hline \multirow[b]{2}{*}{ Releuse Type } & \multirow[b]{2}{*}{$\begin{array}{l}\text { Meteorological } \\
\text { conditions }\end{array}$} & \multicolumn{3}{|c|}{$\begin{array}{l}\text { Peak concentration (time to) } \\
\left(\mathrm{mg} / \mathrm{m}^{3}\right) \quad(\mathrm{min})\end{array}$} & \multicolumn{2}{|c|}{$\begin{array}{l}\text { Protective action criteria } \\
\qquad\left(\mathbf{m g} / \mathbf{m}^{3}\right)\end{array}$} & \multirow{2}{*}{$\begin{array}{c}\text { Highest } \\
\text { emergency } \\
\text { class }\end{array}$} & \multicolumn{3}{|c|}{$\begin{array}{l}\text { Distance to ERPG or equivalent } \\
\qquad(\mathrm{m})\end{array}$} \\
\hline & & $100 \mathrm{~m}$ & $756 \mathrm{~m}$ & $5,200 \mathrm{~m}$ & Alert ${ }^{6}$ & $\begin{array}{l}\text { Site Area or General } \\
\text { Emergency }^{c}\end{array}$ & & $\begin{array}{l}\text { ERPG- } 1 \text { or } \\
\text { equivalent }\end{array}$ & $\begin{array}{l}\text { ERPG- } 2 \text { or } \\
\text { equivalent }\end{array}$ & $\begin{array}{l}\text { ERPG-3 or } \\
\text { equivalent }\end{array}$ \\
\hline \multirow{3}{*}{ Direct } & $95 \%$ worst-case & $130(2)$ & $0.91(13)$ & $\mathrm{NSC}^{\boldsymbol{e}}$ & 1 & 2.5 & Site Area & 720 & 500 & $N L A^{f}$ \\
\hline & & & & & & & & & & \\
\hline & Typical & $20(1)$ & $0.43(5)$ & NSC & 1 & 2.5 & Site Area & 920 & 700 & NLA \\
\hline
\end{tabular}

a. Protective action criteria are based on company guidelines for determining event classification. The definitions for event classifications of hazardous material releases at the INEL are discussed in the text.

b. The Alert protective action criteria value listod is the ERPG-1 equivalent (TLV-STEL) value for toxaphene.

c. The Site Area Emergency and General Emergency protective action criteria value listed is the ERPG-2 equivalent (5*TLV-TWA) value for toxaphene.

d. The company guidelines for ERPGs and ERPG equivalents are discussed in the text. There is no ERPG-3 or equivalent concentration for toxaphene.

e. NSC stands for No Significant Consequences. The estimated airborne concentration was not significant at this receptor location or the ERPG (or equivalent) concentration was not exceeded at $100 \mathrm{~m}$.

f. NLA stands for No Limit Available. NLA indicates that an ERPG or equivalent concentration limit was not available for the hazardous material. 
Table C-87. Summary of event consequences for a release of toxaphene $(4,540 \mathrm{~kg})$.

\begin{tabular}{|c|c|c|c|c|c|c|c|c|c|c|}
\hline \multirow[b]{2}{*}{ Release Type } & \multirow[b]{2}{*}{$\begin{array}{l}\text { Metcorological } \\
\text { conditions }\end{array}$} & \multicolumn{3}{|c|}{$\begin{array}{l}\text { Peak concentration (time to) } \\
\qquad\left(\mathrm{mg} / \mathrm{m}^{3}\right) \quad(\mathrm{min})\end{array}$} & \multicolumn{2}{|c|}{$\begin{array}{l}\text { Protective action criteris } \\
\left(\mathbf{m g} / \mathrm{m}^{3}\right)\end{array}$} & \multirow{2}{*}{$\begin{array}{c}\begin{array}{c}\text { Highest } \\
\text { emergency } \\
\text { class }\end{array} \\
\end{array}$} & \multicolumn{3}{|c|}{$\begin{array}{l}\text { Distance to ERPG or equivalent }{ }^{d} \\
\qquad(\mathrm{~m})\end{array}$} \\
\hline & & $100 \mathrm{~m}$ & $756 \mathrm{~m}$ & $5,200 \mathrm{~m}$ & Aler ${ }^{b}$ & $\begin{array}{l}\text { Site Area or General } \\
\text { Emergency }\end{array}$ & & $\begin{array}{l}\text { ERPG-1 or } \\
\text { equivalent }\end{array}$ & $\begin{array}{l}\text { ERPG- } 2 \text { or } \\
\text { equivalent }\end{array}$ & $\begin{array}{l}\text { ERPG-3 or } \\
\text { equivalent }\end{array}$ \\
\hline \multirow{3}{*}{ Direct } & $95 \%$ woryt-case & $2,500(2)$ & $18(13)$ & $0.18(87)$ & 1 & 2.5 & Sile Area & 2,500 & 1,700 & $\mathrm{NLA}^{f}$ \\
\hline & & & & & & . & & & & \\
\hline & Typical & $400(1)$ & $8.6(5)$ & $0.35(35)$ & 1 & 2.5 & Site Area & 2,600 & 1,500 & NL_A \\
\hline
\end{tabular}

a. Protective action criteria are based on company guidelines for determining event classification. The definitions for event classifications of hazardous material releases at the INEL are discussed in the text.

b. The Alen protective action criteria value listed is the ERPG-I equivalent (TLV-STEL) value for toxaphene.

c. The Site Area Emergency and General Emergency protective action criteria value listed is the ERPG-2 equivalent (5*TLV-TWA) value for toxaphene.

d. The company guidelines for ERPGs and ERPG equivalents are discussed in the text. There is no ERPG-3 or equivalent concentration for toxaphene.

e. NSC stands for No Significant Consequences. The estimated airborne concentration was not significant at this receptor location or the ERPG (or equivalent) concentration was not exceeded at $100 \mathrm{~m}$.

f. NLA stands for No Limit Available. NLA indicates that an ERPG or equivalent concentration limit was not available for the hazardous material. 
Table C-88. Summary of event consequences for a release of trans-1,2-dichloroethane.

\begin{tabular}{|c|c|c|c|c|c|c|c|c|c|c|}
\hline \multirow[b]{2}{*}{ Release Type } & \multirow[b]{2}{*}{$\begin{array}{l}\text { Meteorological } \\
\text { conditions }\end{array}$} & \multicolumn{3}{|c|}{$\begin{array}{l}\begin{array}{c}\text { Peak concentration (time to) } \\
(\mathrm{ppm})\end{array} \\
\text { (min) }\end{array}$} & \multicolumn{2}{|c|}{$\begin{array}{l}\text { Protective action criteria } \\
\text { (ppm) }\end{array}$} & \multirow{2}{*}{$\begin{array}{l}\text { Highest } \\
\text { emergency } \\
\text { class }\end{array}$} & \multicolumn{3}{|c|}{$\begin{array}{l}\text { Distance to ERPG or equivalent } \\
\qquad(\mathrm{m})\end{array}$} \\
\hline & & $100 \mathrm{~m}$ & $756 \mathrm{~m}$ & $5,200 \mathrm{~m}$ & Alert $^{b}$ & $\begin{array}{l}\text { Site Area or General } \\
\text { Emergency }\end{array}$ & & $\begin{array}{l}\text { ERPG-1 or } \\
\text { equivalent }\end{array}$ & $\begin{array}{l}\text { ERPG-2 or } \\
\text { equivalent }\end{array}$ & $\begin{array}{l}\text { ERPG } 3 \text { or } \\
\text { equivalent }\end{array}$ \\
\hline & $95 \%$ worst-case & $1.8(2)$ & $0.034(13)$ & $\mathrm{NSC}^{\star}$ & 2 & 5 & . & NSC & NSC & NSC \\
\hline \multicolumn{11}{|l|}{ Direct } \\
\hline & Typical & $0.11(1)$ & NSC & $\mathrm{NSC}$ & 2 & 5 & . & NSC & NSC & NSC \\
\hline & $95 \%$ worst-case & $17(2)$ & $0.4(13)$ & NSC & 2 & 5 & Site Area & 320 & 190 & NSC \\
\hline \multicolumn{11}{|l|}{ Spill } \\
\hline & Typical & $1.2(1)$ & NSC & NSC & 2 & 5 & - & $\mathrm{NSC}$ & NSC & NSC \\
\hline & $95 \%$ worst-case & $67(2)$ & $1.6(13)$ & NSC & 2 & 5 & Site Area & 650 & 410 & NSC \\
\hline \multicolumn{11}{|l|}{ Spill w/ fire } \\
\hline & Typical & $4.6(1)$ & $0.13(5)$ & NSC & 2 & 5 & Alent & 150 & NSC & NSC \\
\hline
\end{tabular}

a. Protective action criteria are based on company guidelines for determining event classification. The definitions for event classifications of hazardous material releases at the INEL are discussed in the text.

b. The Alert protective action criteria value listed is the ERPG-1 equivalent (TLV-STEL) value for trans-1,2-dichlorocthane.

c. The Site Area Emergency and General Emergency protective action criteria value listed is the ERPG-2 equivalent (S*TLV-TWA) value for trans-1,2-dichloroethane.

d. The company guidelines for ERPGs and ERPG equivalents are discussed in the text. The ERPG-3 equivalent (IDLH) concentration of 1,000 ppm for trans-1,2-dichloroethane was used.

e. NSC stands for No Significant Consequences. The estimated airborne concentration was not significant at this receptor location or the ERPG (or equivalent) concentration was not exceeded at $100 \mathrm{~m}$. 
Table C-89. Summary of event consequences for a release of 1,2,4-trichlorobenzene.

\begin{tabular}{|c|c|c|c|c|c|c|c|c|c|c|}
\hline \multirow[b]{2}{*}{ Release Type } & \multirow[b]{2}{*}{$\begin{array}{l}\text { Meteorological } \\
\text { conditions }\end{array}$} & \multicolumn{3}{|c|}{$\begin{array}{c}\begin{array}{c}\text { Peak concentration (ime to } \\
(\mathrm{ppm}) \quad(\mathrm{min})\end{array} \\
\end{array}$} & \multicolumn{2}{|c|}{$\begin{array}{c}\text { Protective action criteriag } \\
\text { (pprn) }\end{array}$} & \multirow{2}{*}{$\begin{array}{c}\text { Highest } \\
\text { emergency } \\
\text { class }\end{array}$} & \multicolumn{3}{|c|}{$\begin{array}{l}\text { Distance to ERPG or equivalent } \\
\text { (m) }\end{array}$} \\
\hline & & $100 \mathrm{~m}$ & $756 \mathrm{~m}$ & $5,200 \mathrm{~m}$ & Alert $^{b}$ & $\begin{array}{l}\text { Site Area or General } \\
\text { Emergencyc }\end{array}$ & & $\begin{array}{l}\text { ERPG-1 or } \\
\text { equivalent }\end{array}$ & $\begin{array}{l}\text { ERPG-2 or } \\
\text { equivalent }\end{array}$ & $\begin{array}{l}\text { ERPG- } 3 \text { or } \\
\text { equivalent }\end{array}$ \\
\hline & $95 \%$ worst-case & $10(2)$ & $0.19(13)$ & $\mathrm{NSC}^{\mathrm{c}}$ & $N L A^{f}$ & 5 & Site Area & NLA & 434 & NILA \\
\hline \multicolumn{11}{|l|}{ Direct } \\
\hline & Typical & $0.6(1)$ & NSC & NSC & NLA & 5 & - & NLA & $\mathrm{NSC}$ & NLA \\
\hline & $95 \%$ worst-case & $0.15(2)$ & NSC & NSC & NLA & 5 & - & NLA & $\mathrm{NSC}$ & NLA \\
\hline \multicolumn{11}{|l|}{ Spill } \\
\hline & Typical & $0.011(1)$ & NSC & NSC & NLA & 5 & . & NLA & NSC & NLA \\
\hline \multirow{3}{*}{ Spill w/ fire } & $95 \%$ worst-case & $4.2(2)$ & $0.11(13)$ & NSC & NLA & 5 & - & NLA & NSC & NLA \\
\hline & & & & & & & & & & \\
\hline & Typical & $0.3(1)$ & NSC & NSC & NLA & 5 & . & NLA & NSC & NLA \\
\hline
\end{tabular}

a. Protective action criteria are based on company guidelines for determining event classification. The definitions for event classifications of hazardous material releases at the INEL are discussed in the text.

b. There is no alen protective action criteria value listed for 1,2,4-trichlorobenzene.

c. The Site Area Emergency and General Emergency protective action criteria value listed is the ERPG-2 equivalent (PEL-C) value for 1,2,4-trichlorobenzene.

d. The company guidelines for ERPGs and ERPG equivalents are discussed in the text. There is no ERPG-3 or equivalent concentration for 1,2,4-trichlorobenzene.

e. NSC stands for No Significant Consequences. The estimated airbome concentration was not significant at this receptor location or the ERPG (or equivalent) concentration was not exceeded at $100 \mathrm{~m}$.

f. NLA stands for No Limit Available. NLA indicates that an ERPG or equivalent concentration limit was not available for the hazardous material. 
Table C-90. Summary of event consequences for a release of 1,1,1-trichloroethane.

\begin{tabular}{|c|c|c|c|c|c|c|c|c|c|c|}
\hline \multirow[b]{2}{*}{ Release Type } & \multirow[b]{2}{*}{$\begin{array}{l}\text { Meteorological } \\
\text { conditions }\end{array}$} & \multicolumn{3}{|c|}{ 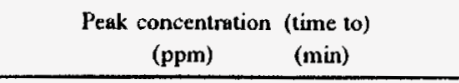 } & \multicolumn{2}{|c|}{$\begin{array}{l}\text { Protective action criterias } \\
\text { (ppm) }\end{array}$} & \multirow{2}{*}{$\begin{array}{c}\text { Highest } \\
\text { emergency } \\
\text { class }\end{array}$} & \multicolumn{3}{|c|}{$\begin{array}{l}\text { Distance to ERPG or equivalent }{ }^{d} \\
(\mathrm{~m})\end{array}$} \\
\hline & & $100 \mathrm{~m}$ & $756 \mathrm{~m}$ & $5,200 \mathrm{~m}$ & Alert $^{b}$ & $\begin{array}{l}\text { Site Area or General } \\
\text { Emergency }{ }^{\circ}\end{array}$ & & $\begin{array}{l}\text { ERPG- } 1 \text { or } \\
\text { equivalent }\end{array}$ & $\begin{array}{l}\text { ERPG-2 or } \\
\text { equivalent }\end{array}$ & $\begin{array}{l}\text { ERPG-3 or } \\
\text { equivalent }\end{array}$ \\
\hline & $95 \%$ worst-case & $130(2)$ & $2.6(13)$ & $\mathrm{NSC}^{\mathrm{e}}$ & 500 & 1.000 & - & NSC & NSC & NSC \\
\hline \multicolumn{11}{|l|}{ Direct } \\
\hline & Typical & $8.1(1)$ & NSC & NSC & 500 & 1,000 & - & NSC & NSC & NSC \\
\hline & $95 \%$ worst-case & $47(2)$ & $1.2(13)$ & NSC & 500 & 1,000 & - & NSC & NSC & NSC \\
\hline \multicolumn{11}{|l|}{ Spill } \\
\hline & Typical & $3.4(1)$ & NSC & NSC & 500 & 1,000 & - & NSC & NSC & NSC \\
\hline & $95 \%$ wonst-case & $300(2)$ & $8.0(13)$ & NSC & 500 & 1,000 & - & NSC & NSC & NSC \\
\hline \multicolumn{11}{|l|}{ Spill w/ fire } \\
\hline & Typical & $22(1)$ & NSC & NSC & 500 & 1,000 & - & NSC & NSC & NSC \\
\hline
\end{tabular}

a. Protective action criteria are based on company guidelines for determining event classification. The definitions for event classifications of hazardous material releases at the INEL are discussed in the text.

b. The Alert protective action criteria value listed is the ERPG-1 value for 1,1,1-trichloroethane.

c. The Site Area Emergency and General Emergency protective action criteria value listed is the ERPG-2 value for 1,1,1-trichloroethane.

d. The company guidelines for ERPGs and ERPG equivalents are discussed in the text. The ERPG-3 concentration of 3,000 ppm for 1,1,1-trichloroethanewas used.

e. NSC stands for No Significant Consequences. The estimated airborne concentration was not significant at this receptor location or the ERPG (or equivalent) concentration was not exceeded at $100 \mathrm{~m}$. 
Table C-91. Summary of event consequences for a release of trichloroethene.

\begin{tabular}{|c|c|c|c|c|c|c|c|c|c|c|}
\hline \multirow[b]{2}{*}{ Release Type } & \multirow[b]{2}{*}{$\begin{array}{l}\text { Meteorological } \\
\text { conditions }\end{array}$} & \multicolumn{3}{|c|}{$\begin{array}{l}\text { Peak concentration (time to) } \\
(\mathbf{p p m}) \quad(\mathrm{min})\end{array}$} & \multicolumn{2}{|c|}{$\begin{array}{l}\text { Protective action criteria } \\
\text { (ppm) }\end{array}$} & \multirow{2}{*}{$\begin{array}{c}\text { Highest } \\
\text { emergency } \\
\text { class }\end{array}$} & \multicolumn{3}{|c|}{$\begin{array}{l}\text { Distance to ERPG or equivalent } t^{d} \\
(\mathrm{~m})\end{array}$} \\
\hline & & $100 \mathrm{~m}$ & $756 \mathrm{~m}$ & $5,200 \mathrm{~m}$ & Aler ${ }^{b}$ & $\begin{array}{l}\text { Site Area or General } \\
\text { Emergency }^{c}\end{array}$ & & $\begin{array}{l}\text { ERPG-1 or } \\
\text { equivalent }\end{array}$ & $\begin{array}{l}\text { ERPG-2 or } \\
\text { equivalent }\end{array}$ & $\begin{array}{l}\text { ERPG-3 or } \\
\text { equivalent }\end{array}$ \\
\hline & $95 \%$ worst-case & $13(2)$ & $0.26(13)$ & $\mathrm{NSC}^{\mathrm{c}}$ & 100 & 500 & : & NSC & $\mathrm{NSC}$ & NSC \\
\hline \multicolumn{11}{|l|}{ Direat } \\
\hline & Typical & $0.83(1)$ & NSC & NSC & 100 & 500 & $:$ & NSC & NSC & $\mathrm{NSC}$ \\
\hline & $95 \%$ worst-case & $28(2)$ & NSC & NSC & 100 & 500 & $\therefore$ & $\mathrm{NSC}$ & NSC & NSC \\
\hline \multicolumn{11}{|l|}{ Spill } \\
\hline & Typical & $2.0(1)$ & NSC & NSC & 100 & 500 & - & NSC & NSC & NSC \\
\hline & $95 \%$ worst-case & $240(2)$ & $6.4(13)$ & NSC & 100 & 500 & Alert & 160 & NSC & NSC \\
\hline \multicolumn{11}{|l|}{ Spill w/ fire } \\
\hline & Typical & $17(1)$ & NSC & NSC & 100 & 500 & - & NSC & NSC & NSC \\
\hline
\end{tabular}

a. Protective action criteria are based on company guidelines for determining event classification. The definitions for event classifications of hazardous material releases at the INEL are discussed in the text.

b. The Alert protective action criteria value listed is the ERPG-1 value for trichloroethene.

c. The Site Area Emergency and General Emergency protective action criteria value listed is the ERPG-2 value for trichloroethene.

d. The company guidelines for ERPGs and ERPG equivalents are discussed in the text. The ERPG-3 concentration of 1,000 ppm for trichloroethene was used.

e. NSC stands for No Significant Consequences. The estimated airborne concentration was not significant at this receptor location or the ERPG (or equivalent) concentration was not exceeded at $100 \mathrm{~m}$. 
Table C-92. Summary of event consequences for a release of trichloroethylene.

\begin{tabular}{|c|c|c|c|c|c|c|c|c|c|c|}
\hline \multirow[b]{2}{*}{ Release Type } & \multirow[b]{2}{*}{$\begin{array}{l}\text { Meteorological } \\
\text { conditions }\end{array}$} & \multicolumn{3}{|c|}{$\begin{array}{l}\text { Peak concentration (time to) } \\
\begin{array}{c}(\mathrm{ppm}) \\
(\mathrm{min})\end{array}\end{array}$} & \multicolumn{2}{|c|}{$\begin{array}{c}\text { Protective action criteria } \\
\text { (ppm) }\end{array}$} & \multirow{2}{*}{$\begin{array}{l}\text { Highest } \\
\text { emergency } \\
\text { class }\end{array}$} & \multicolumn{3}{|c|}{$\begin{array}{l}\text { Distance to ERPG or equivalent } \\
(\mathrm{m})\end{array}$} \\
\hline & & $100 \mathrm{~m}$ & $756 \mathrm{~m}$ & $5,200 \mathrm{~m}$ & Alen $^{b}$ & $\begin{array}{l}\text { Site Area or General } \\
\text { Emergency }{ }^{c}\end{array}$ & & $\begin{array}{l}\text { ERPG-1 or } \\
\text { equivalent }\end{array}$ & $\begin{array}{l}\text { ERPG-2 or } \\
\text { equivalent }\end{array}$ & $\begin{array}{l}\text { ERPG-3 or } \\
\text { equivalent }\end{array}$ \\
\hline & $95 \%$ worst-cuse & $6.39(5)$ & $\mathrm{NSC}^{\mathrm{e}}$ & NSC & 100 & 500 & . & NSC & NSC & NSC \\
\hline \multicolumn{11}{|l|}{ Direct } \\
\hline & Typical & $1.91(3)$ & NSC & NSC & 100 & 500 & - & NSC & $\mathrm{NSC}$ & NSC \\
\hline & $95 \%$ worst-case & $20.8(5)$ & NSC & NSC & 100 & 500 & - & NSC & NSC & NSC \\
\hline \multicolumn{11}{|l|}{ Spill } \\
\hline & Typical & $6.47(1)$ & NSC & NSC & 100 & 500 & & NSC & NSC & NSC \\
\hline & $95 \%$ worst-case & $205(6)$ & $4.32(30)$ & NSC & 100 & 500 & Alent & 150 & $\mathrm{NSC}$ & NSC \\
\hline \multicolumn{11}{|l|}{ Spill w/ fire } \\
\hline & Typical & $202(3)$ & $5.4(8)$ & NSC & 100 & 500 & Alert & 150 & NSC & NSC \\
\hline
\end{tabular}

a. Protective action criteria are based on company guidelines for determining event classification. The definitions for event classifications of hazardous material releases at the INEL are discussed in the text.

b. The Alert protective action criteria value listed is the draft ERPG-I value for trichloroethylene.

c. The Site Area Emergency and General Emergency protective action criteria value listed is the draft ERPG-2 value for trichloroethylene.

d. The company guidelines for ERPGs and ERPG equivalents are discussed in the text. The draft ERPG-3 concentration of 1,000 ppm for trichloroethylene was used.

e. NSC stands for No Significant Consequences. The estimated airborne concentration was not significant at this receptor location or the ERPG (or equivalent) concentration was not exceeded at $100 \mathrm{~m}$. 

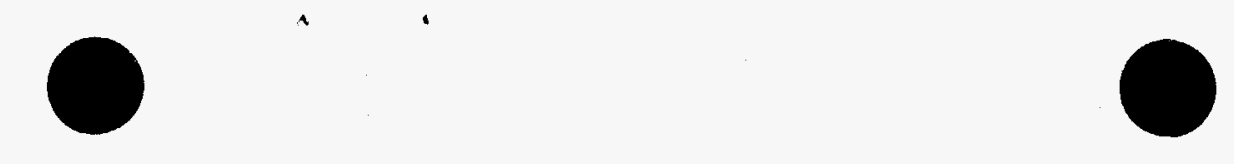

Table C-93. Summary of event consequences for a release of 2,4,5-trichlorophenol.

\begin{tabular}{|c|c|c|c|c|c|c|c|c|c|c|}
\hline \multirow[b]{2}{*}{ Release Type } & \multirow[b]{2}{*}{$\begin{array}{c}\text { Meteorological } \\
\text { conditions }\end{array}$} & \multicolumn{3}{|c|}{$\begin{array}{l}\text { Peak concentration (time to) } \\
\qquad(\mathrm{ppm}) \quad(\mathrm{min})\end{array}$} & \multicolumn{2}{|c|}{$\begin{array}{l}\text { Protective action criteris } \\
\text { (ppm) }\end{array}$} & \multirow{2}{*}{$\begin{array}{c}\text { Highest } \\
\text { emergency } \\
\text { class }\end{array}$} & \multicolumn{3}{|c|}{$\begin{array}{l}\text { Distance to ERPG or equivalent } \\
(\mathrm{m})\end{array}$} \\
\hline & & $100 \mathrm{~m}$ & $756 \mathrm{~m}$ & $5,200 \mathrm{~m}$ & Alert $^{\circ}$ & $\begin{array}{c}\text { Site Area or General } \\
\text { Emergency }{ }^{c}\end{array}$ & & $\begin{array}{l}\text { ERPG-1 or } \\
\text { equivalent }\end{array}$ & $\begin{array}{l}\text { ERPG-2 or } \\
\text { equivalent }\end{array}$ & $\begin{array}{l}\text { ERPG-3 or } \\
\text { equivalent }\end{array}$ \\
\hline & $95 \%$ worst-case & $0.98(4)$ & $\mathrm{NSC}^{\mathrm{e}}$ & NSC & 6 & 10 & - & NSC & NSC & NLA $^{\prime}$ \\
\hline \multicolumn{11}{|l|}{ Direct } \\
\hline & Typical & $0.05(2)$ & NSC & NSC & 6 & 10 & & NSC & NSC & NLA \\
\hline
\end{tabular}

a. Protective action criteria are based on company guidelines for determining event classification. The definitions for event classifications of hazardous material releases at the INEL are discussed in the text.

b. The Alert protective action criteria value listed is the ERPG-1 equivalent (estimated by WERF IH) value for 2,4,5-trichlorophenol.

c. The Site Area Emergency and General Emergency protective action criteria value listed is the ERPG-2 equivalent (estimated by WERF IH) value for 2,4,5-trichlorophenol.

d. The company guidelines for ERPGs and ERPG equivalents are discussed in the text. There is no ERPG-3 or equivalent concentration for 2,4,5-trichlorophenol.

e. NSC stands for No Significant Consequences. The estimated airbome concentration was not significant at this receptor location or the ERPG (or equivalent) concentration was not exceeded at $100 \mathrm{~m}$. 
Table C-94. Summary of event consequences for a release of 2,4,6-trichlorophenol.

\begin{tabular}{|c|c|c|c|c|c|c|c|c|c|c|}
\hline \multirow[b]{2}{*}{ Release Type } & \multirow[b]{2}{*}{$\begin{array}{c}\text { Meteorological } \\
\text { conditions }\end{array}$} & \multicolumn{3}{|c|}{$\begin{array}{l}\text { Peak concentration (time to) } \\
\begin{array}{c}(\mathrm{ppm}) \\
(\mathrm{min})\end{array}\end{array}$} & \multicolumn{2}{|c|}{$\begin{array}{l}\text { Protective action criteriaa } \\
\text { (ppm) }\end{array}$} & \multirow{2}{*}{$\begin{array}{c}\text { Highest } \\
\text { emergency } \\
\text { class }\end{array}$} & \multicolumn{3}{|c|}{$\begin{array}{c}\text { Distance to ERPG or equivalent } \\
(\mathrm{m})\end{array}$} \\
\hline & & $100 \mathrm{~m}$ & $756 \mathrm{~m}$ & $5,200 \mathrm{~m}$ & Alert $^{b}$ & $\begin{array}{l}\text { Site Area or General } \\
\text { Emergencyc }\end{array}$ & & $\begin{array}{l}\text { ERPG-1 or } \\
\text { equivalent }\end{array}$ & $\begin{array}{l}\text { ERPG-2 or } \\
\text { equivalent }\end{array}$ & $\begin{array}{l}\text { ERPG-3 or } \\
\text { equivalent }\end{array}$ \\
\hline & $95 \%$ worst-case & $0.98(4)$ & $\mathrm{NSC}^{e}$ & NSC & 6 & 10 & - & NSC & NSC & $\mathrm{NLA}^{f}$ \\
\hline \multicolumn{11}{|l|}{ Direct } \\
\hline & Typical & $0.05(3)$ & NSC & NSC & 6 & 10 & - & NSC & NSC & NLA \\
\hline
\end{tabular}

a. Protective action criteria are based on company guidelines for determining event classification. The definitions for event classifications of hazardous material releases at the INEL are discussed in the text.

b. The Alert protective action criteria value listed is the ERPG-1 equivalent (estimated by WERF IH) value for 2,4,6-trichlorophenol.

c. The Site Area Emergency and General Emergency protective action criteria value listed is the ERPG-2 equivalent (estimated by WERF IH) value for $2,4,6-t r i c h l o r o p h e n o l$.

d. The company guidelines for ERPGs and ERPG equivalents are discussed in the text. There is no ERPG-3 or equivalent concentration for 2,4,6-trichlorophenol.

e. NSC stands for No Significant Consequences. The estimated airborne concentration was not significant at this receptor location or the ERPG (or equivalent) concentration was not exceeded at $100 \mathrm{~m}$.

f. NIA stands for No Limit Available. NLA indicates that an ERPG or equivalent concentration limit w'as not available for the hazardous material. 
Table C-95. Summary of event consequences for a release of vinyl chloride.

\begin{tabular}{|c|c|c|c|c|c|c|c|c|c|c|}
\hline \multirow[b]{2}{*}{ Release Type } & \multirow[b]{2}{*}{$\begin{array}{l}\text { Meteorological } \\
\text { conditions }\end{array}$} & \multicolumn{3}{|c|}{$\begin{array}{l}\text { Peak concentration (time to) } \\
(\text { ppm) (min) }\end{array}$} & \multicolumn{2}{|c|}{$\begin{array}{l}\text { Protective action criteria } \\
\text { (ppm) }\end{array}$} & \multirow{2}{*}{$\begin{array}{c}\text { Highest } \\
\text { emergency } \\
\text { class }\end{array}$} & \multicolumn{3}{|c|}{$\begin{array}{l}\text { Distance to ERPG or equivalent } \\
\text { (m) }\end{array}$} \\
\hline & & $100 \mathrm{~m}$ & $756 \mathrm{~m}$ & $5,200 \mathrm{~m}$ & Alert ${ }^{\mathrm{b}}$ & $\begin{array}{l}\text { Site Area or General } \\
\text { Emergency }^{c}\end{array}$ & & $\begin{array}{l}\text { ERPG-1 or } \\
\text { equivalent }\end{array}$ & $\begin{array}{l}\text { ERPG- } 2 \text { or } \\
\text { equivalent }\end{array}$ & $\begin{array}{l}\text { ERPG-3 or } \\
\text { equivalent }\end{array}$ \\
\hline \multirow{3}{*}{ Direct } & $95 \%$ worst-case & $0.235(3)$ & $0.0055(16)$ & $\mathrm{NSC}^{e}$ & 15 & 25 & $=$ & NSC & NSC & $\mathrm{NLA}^{f}$ \\
\hline & & & & & & & & & & \\
\hline & Typical & $0.017(2)$ & NSC & NSC & 15 & 25 & - & NSC & NSC & NLA \\
\hline
\end{tabular}

a. Protective action criteria are based on company guidelines for determining event classification. The definitions for event classifications of hazardous material releases at the INEL are diseussed in the text.

b. The Alen protective action criteria value listed is the ERPG-1 equivalent (3*TLV-TWA) value for vinyl chloride.

c. The Site Area Emergency and General Emergency protective action criteria value listed is the ERPG-2 equivalent (5*TWA-TLV) value for vinyl chloride.

d. The company guidelines for ERPGs and ERPG equivalents are discussed in the text. There is no ERPG-3 or equivalent concentration for vinyl chloride.

e. NSC stands for No Significant Consequences. The estimated airbome concentration was not significant at this receptor location or the ERPG (or equivalent) concentration was not exceeded at $100 \mathrm{~m}$.

f. NLA stands for No Limit Available. NLA indicates that an ERPG or equivalent concentration limit was not available for the hazardous material. 
Table C-96. Summary of event consequences for a release of xylene-m.

\begin{tabular}{|c|c|c|c|c|c|c|c|c|c|c|}
\hline \multirow[b]{2}{*}{ Release Type } & \multirow[b]{2}{*}{$\begin{array}{c}\text { Meteorological } \\
\text { conditions }\end{array}$} & \multicolumn{3}{|c|}{$\begin{array}{c}\begin{array}{c}\text { Peak concentration (time to) } \\
\text { (ppm) }\end{array} \quad(\mathrm{min}) \\
\end{array}$} & \multicolumn{2}{|c|}{$\begin{array}{l}\text { Protective action criteria } \\
\text { (ppm) } \\
\end{array}$} & \multirow{2}{*}{$\begin{array}{c}\text { Highest } \\
\text { emergency } \\
\text { class } \\
\end{array}$} & \multicolumn{3}{|c|}{$\begin{array}{l}\text { Distance to ERPG or equivalent }{ }^{d} \\
\text { (m) }\end{array}$} \\
\hline & & $100 \mathrm{~m}$ & $756 \mathrm{~m}$ & $5,200 \mathrm{~m}$ & Aler $^{b}$ & $\begin{array}{l}\text { Site Area or General } \\
\text { Emergency }{ }^{\mathrm{c}}\end{array}$ & & $\begin{array}{l}\text { ERPG-1 or } \\
\text { equivalent }\end{array}$ & $\begin{array}{l}\text { ERPG }-2 \text { or } \\
\text { equivalent }\end{array}$ & $\begin{array}{l}\text { ERPG-3 or } \\
\text { equivalent }\end{array}$ \\
\hline & $95 \%$ worst-case & $46.4(5)$ & $\mathrm{NSC}^{\mathrm{e}}$ & NSC & 150 & 500 & - & NSC & NSC & NSC \\
\hline \multicolumn{11}{|l|}{ Direat } \\
\hline & Typical & $22.6(3)$ & NSC & NSC & 150 & 500 & - & NSC & $\mathrm{NSC}$ & NSC \\
\hline & $95 \%$ worst-case & $9.32(4)$ & NSC & $\mathrm{NSC}$ & 150 & 500 & - & NSC & NSC & NSC \\
\hline \multicolumn{11}{|l|}{ Spill } \\
\hline & Typical & $1.07(2)$ & NSC & NSC & 150 & 500 & - & NSC & NSC & NSC \\
\hline \multirow{3}{*}{ Spill w/ fire } & $95 \%$ worst-case & $245(5)$ & NSC & NSC & 150 & 500 & Alert & 129 & $\mathrm{NSC}$ & NSC \\
\hline & & & & & & & & & & \\
\hline & Typical & $244(4)$ & $\mathrm{NSC}$ & NSC & 150 & 500 & Alert & 125 & NȘC & NSC \\
\hline
\end{tabular}

a. Protective action criteria are based on company guidelines for determining event classification. The definitions for event classifications of hazardous material releases at the INEL. are discussed in the text.

b. The Alert protective action criteria value listed is the ERPG-I equivalent (TLV-STEL) value for xylene-m.

c. The Site Area Emergency and General Emergency protective action criteria value listed is the ERPG-2 equivalent (5*TLV-TWA) value for xylene-m.

d. The company guidelines for ERPGs and ERPG equivalents are discussed in the text. The ERPG-3 equivalent (IDLH) concentration of $1,000 \mathrm{ppm}$ for $x y$ lene-m was used.

e. NSC stands for No Significant Consequences. The estimated airborne concentration was not significant at this receptor location or the ERPG (or equivalent) concentration was not exceeded at $100 \mathrm{~m}$ 
Table C-97. Summary of event consequences for a release of xylene-0.

\begin{tabular}{|c|c|c|c|c|c|c|c|c|c|c|}
\hline \multirow[b]{2}{*}{ Release Type } & \multirow[b]{2}{*}{$\begin{array}{c}\text { Meteorological } \\
\text { conditions }\end{array}$} & \multicolumn{3}{|c|}{$\begin{array}{l}\text { Peak concentration (time to) } \\
\text { (ppm) } \quad(\mathrm{min})\end{array}$} & \multicolumn{2}{|c|}{$\begin{array}{l}\text { Protective action criteria } \\
\qquad(\mathrm{ppm})\end{array}$} & \multirow{2}{*}{$\begin{array}{c}\text { Highest } \\
\text { emergency } \\
\text { class }\end{array}$} & \multicolumn{3}{|c|}{$\begin{array}{l}\text { Distance to ERPG or equivalent }{ }^{d} \\
\text { (m) }\end{array}$} \\
\hline & & $100 \mathrm{~m}$ & $756 \mathrm{~m}$ & $5,200 \mathrm{~m}$ & Alert & $\begin{array}{l}\text { Site Area or General } \\
\text { Emergency }^{*}\end{array}$ & & $\begin{array}{l}\text { ERPG-1 or } \\
\text { equivalent }\end{array}$ & $\begin{array}{l}\text { ERPG-2 or } \\
\text { equivalent }\end{array}$ & $\begin{array}{l}\text { ERPG-3 or } \\
\text { equivalent }\end{array}$ \\
\hline & $95 \%$ worst-case & $46.4(5)$ & $\mathrm{NSC}^{\mathrm{e}}$ & NSC & 150 & 500 & - & NSC & NSC & NSC \\
\hline \multicolumn{11}{|l|}{ Direct } \\
\hline & Typical & $22.6(3)$ & NSC & NSC & 150 & 500 & - & NSC & NSC & NSC \\
\hline & $95 \%$ worst-case & $7.5(4)$ & NSC & $\mathrm{NSC}$ & 150 & 500 & - & NSC & NSC & NSC \\
\hline \multicolumn{11}{|l|}{ Spill } \\
\hline & Typical & $0,86(1)$ & NSC & NSC & 150 & 500 & - & NSC & NSC & $\mathrm{NSC}$ \\
\hline & $95 \%$ worst-case & $232(5)$ & NSC & $\mathrm{NSC}$ & 150 & 500 & Alent & 150 & NSC & NSC \\
\hline \multicolumn{11}{|l|}{ Spill w/ fire } \\
\hline & Typical & $231(4)$ & NSC & NSC & 150 & 500 & Alert & 150 & NSC & NSC \\
\hline
\end{tabular}

a. Protective action criteria are based on company guidelines for determining event classification. The definitions for event classifications of hazardous material releases at the INEL are discussed in the text.

b. The Alert protective action criteria value listed is the ERPG-I equivalent (TLV-STEL) value for $x y$ lene-o.

c. The Site Area Energency and General Emergency protective action criteria value listed is the ERPG-2 equivalent ( $5 *$ TLV-TWA) value for $x y$ lene-o.

d. The company guidelines for ERPGs and ERPG equivalents are discussed in the text. The ERPG-3 equivalent (IDLH) concentration of 1,000 ppm for xylenc-o was used.

e. NSC stands for No Significant Consequences. The estimated airbome concentration was not significant at this receptor location or the ERPG (or equivalent) concentration was not exceeded at $100 \mathrm{~m}$. 
Table C-98. Summary of event consequences for a release of xylene-p.

\begin{tabular}{|c|c|c|c|c|c|c|c|c|c|c|}
\hline \multirow[b]{2}{*}{ Release Type } & \multirow[b]{2}{*}{$\begin{array}{l}\text { Meteorological } \\
\text { conditions }\end{array}$} & \multicolumn{3}{|c|}{$\begin{array}{l}\text { Peak concentration (time to) } \\
\begin{array}{c}\text { (ppm) } \quad \text { (min) }\end{array}\end{array}$} & \multicolumn{2}{|c|}{$\begin{array}{l}\text { Protective action criteria" } \\
\text { (ppm) }\end{array}$} & \multirow{2}{*}{$\begin{array}{c}\text { Highest } \\
\text { emergency } \\
\text { class }\end{array}$} & \multicolumn{3}{|c|}{$\begin{array}{l}\text { Distance to ERPG or equivslent }{ }^{d} \\
(\mathrm{~m})\end{array}$} \\
\hline & & $100 \mathrm{~m}$ & $756 \mathrm{~m}$ & $5,200 \mathrm{~m}$ & Alert ${ }^{b}$ & $\begin{array}{l}\text { Site Area or General } \\
\text { Emergency.c }\end{array}$ & & $\begin{array}{l}\text { ERPG-1 or } \\
\text { equivalent }\end{array}$ & $\begin{array}{l}\text { ERPG-2 or } \\
\text { equivalent }\end{array}$ & $\begin{array}{l}\text { ERPG-3 or } \\
\text { equivalent }\end{array}$ \\
\hline & $95 \%$ worst-case & $46.4(5)$ & $\mathrm{NSC}^{\mathrm{e}}$ & NSC & 150 & 500 & - & NSC & NSC & NSC \\
\hline \multicolumn{11}{|l|}{ Direct } \\
\hline & Typical & $22.7(4)$ & NSC & NSC & 150 & 500 & - & NSC & NSC & NSC \\
\hline & $95 \%$ worst-case & $11.5(3)$ & NSC & NSC & 150 & 500 & - & NSC & NSC & NSC \\
\hline \multicolumn{11}{|l|}{ Spill } \\
\hline & Typical & $1.12(2)$ & NSC & $\mathrm{NSC}$ & 150 & 500 & - & NSC & NSC & NSC \\
\hline & $95 \%$ wort-case & $263(6)$ & $8.54(20)$ & NSC & 150 & 500 & Alert & 139 & NSC & NSC \\
\hline \multicolumn{11}{|l|}{ Spill w/ fire } \\
\hline & Typical & $241(4)$ & $8.09(7)$ & NSC & $150^{\circ}$ & 500 & Alert & 136 & NSC & NSC \\
\hline
\end{tabular}

a. Protective action criteria are based on company guidelines for determining event classification. The definitions for event classifications of hazardous material releases at the INEL are discussed in the text.

b. The Alert protective action criteria value listed is the ERPG-1 equivalent (TLV-STEL) value for xylene-p.

c. The Site Area Emergency and General Emergency protective action criteria value listed is the ERPG-2 equivalent (S*TLV-TWA) value for xylene-p.

d. The company guidelines for ERPGa and ERPG equivalents are discussed in the text. The ERPG-3 equivalent (IDLH) concentration of 1,000 ppm for xylene-p was used.

e. NSC stands for No Significant Consequences. The estimated airbome concentration was not significant at this receptor location or the ERPG (or equivalent) concentration was not exceeded at $100 \mathrm{~m}$. 

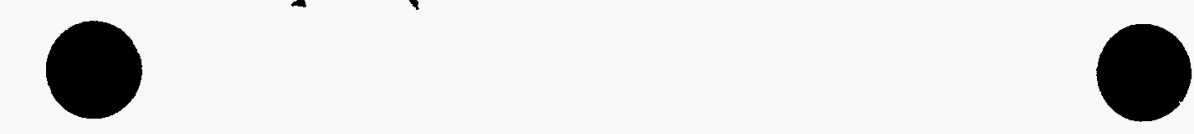

Table C-99. Summary of event consequences for a release of zinc.

\begin{tabular}{|c|c|c|c|c|c|c|c|c|c|c|}
\hline \multirow[b]{2}{*}{ Relesse Type } & \multirow[b]{2}{*}{$\begin{array}{l}\text { Meteorological } \\
\text { conditions }\end{array}$} & \multicolumn{3}{|c|}{$\begin{array}{l}\text { Peak concentration (time to) } \\
\qquad\left(\mathrm{mg} / \mathrm{m}^{3}\right) \quad \text { (min) }\end{array}$} & \multicolumn{2}{|c|}{$\begin{array}{l}\text { Protective action criteria" } \\
\qquad\left(\mathrm{mg} / \mathrm{m}^{3}\right)\end{array}$} & \multirow{2}{*}{$\begin{array}{l}\text { Highest } \\
\text { emergency } \\
\end{array}$} & \multicolumn{3}{|c|}{$\begin{array}{l}\text { Distance to ERPG or equivalent } \\
\qquad(\mathrm{m})\end{array}$} \\
\hline & & $100 \mathrm{~m}$ & $756 \mathrm{~m}$ & $5,200 \mathrm{~m}$ & Alerr & $\begin{array}{l}\text { Site Area or General } \\
\text { Emergency }\end{array}$ & & $\begin{array}{l}\text { ERPG-1 or } \\
\text { equivalent }\end{array}$ & $\begin{array}{l}\text { ERPG-2 or } \\
\text { equivalent }\end{array}$ & $\begin{array}{l}\text { ERPG-3 or } \\
\text { equivalent }\end{array}$ \\
\hline \multirow{3}{*}{ Direat } & $95 \%$ woret-case & $219(5)$ & $10.4(20)$ & $\mathrm{NSC}^{*}$ & 15 & 25 & Sile Area & 576 & 407 & NLA ${ }^{f}$ \\
\hline & & & & & & & & & & \\
\hline & Typical & $101(4)$ & $2.32(8)$ & NSC & 15 & 25 & Site Area & 277 & 211 & NLA \\
\hline
\end{tabular}

a. Protective action criteria are based on company guidelines for determining event classification. The definitions for event classifications of hazardous material releases at the INEL are discussed in the text.

b. The Alert protective action criteria value listed is the ERPG-1 equivalent (eatimated by WERF IH) value for zinc.

c. The Site Area Emergency and General Emergency protective action criteria value listed in the ERPG-2 equivalent (estimated by WERF IH) value for zinc.

d. The company guidelines for ERPG-1 30 minutes or the IDLH (in that order). There is no ERPG-3 or equivalent concentration for zinc.

e. NSC stands for No Significant Consequences. The estimnted airborne concentration was not significant at this receptor location or the ERPG (or equivalent) concentration was not exceeded at $100 \mathrm{~m}$. 